\title{
Late Miocene paleogeography and flora of north-western Wairarapa, New Zealand
}

\section{Kirsten Anne Henden}

\author{
A thesis submitted to \\ Victoria University of Wellington \\ in partial fulfilment of requirements for the degree of
}

\section{Master of Science}

in

Geology

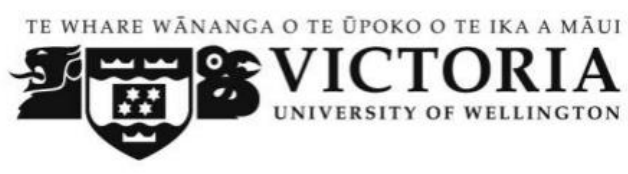

School of Geography, Environment and Earth Sciences

Victoria University of Wellington 


\section{Abstract}

The Late Miocene flora and paleogeography of north-western Wairarapa were determined by examining and sampling the Upper Miocene marine and non-marine deposits of the Mangaoranga Formation. This formation unconformably overlies Mesozoic greywacke basement in areas of north-west Wairarapa and contains the oldest sediments preserved immediately overlying basement in this area. Little work has been carried out previously to fully understand the depositional history of the formation or the surrounding vegetation cover. Thus, the present study is intended to improve interpretations of the Late Miocene paleogeography and flora of northwestern Wairarapa.

The strata of the Mangaoranga Formation were examined at three locations in northwestern Wairarapa: at Mangaoranga Stream (Eketahuna), Central Mangaone Road (Eketahuna) and Mauriceville. For paleogeographic reconstructions, the strata were described at Mangaoranga Stream and subsequently correlated to strata at the Mauriceville and Central Mangaone Road sites. The formation was sampled several times at each site for palynological analysis. Additionally, samples available for pollen analysis from the Mt Bruce and Alfredton areas were also examined. The results of these analyses, in conjunction with mummified leaves, aided reconstructions of the Late Miocene vegetation cover. Fission-track analysis on apatite grains from Torlesse basement immediately below the formation was also undertaken, providing evidence for the cooling (and hence exhumation) and subsequent burial history of the basement strata.

The results of the apatite fission-track analysis suggest that exhumation of the basement strata above the apatite closure temperature $\left(110^{\circ} \mathrm{C}\right)$ occurred between 36 - $25 \mathrm{Ma}$. The basement strata were subsequently exhumed at rates of $0.36-0.20$ $\mathrm{mm} / \mathrm{yr}$ or $0.28-0.16 \mathrm{~mm} / \mathrm{yr}$ until exposed above sea level by about $11 \mathrm{Ma}$. Between 11 and $7 \mathrm{Ma}$, sedimentation of the Mangaoranga Formation occurred. First, northward-flowing braided rivers deposited conglomerate $\left(\mathrm{sm}_{1}\right)$ in half-grabens. At the Mauriceville and Mangaoranga Stream sites, a large co-seismic lake developed, leading to the sedimentation of interbedded sandstone and mudstone ( $\left.\mathrm{sm}_{6}\right)$. The lake persisted for around $95 \mathrm{ky}$ and was often flooded. Eventually, the lake shallowed, and rivers flowed back across the area. The region was subsequently submerged as a marine transgression occurred, leading to the sedimentation of the upper three members of the Mangaoranga Formation (sandstone $\left(\mathrm{sm}_{3}\right)$, siltstone $\left(\mathrm{sm}_{4}\right)$ and mudstone $\left(\mathrm{sm}_{5}\right)$ ). Water depths in north-western Wairarapa reached a maximum of $600 \pm 300 \mathrm{~m}$ by about 8 to $7 \mathrm{Ma}$.

The results of the floral investigation indicate that areas of significant relief were present in north-western Wairarapa during the Late Miocene (possibly up to, or just over, $900 \mathrm{~m}$ above sea level). These areas were occupied by cool temperate beech (Nothofagus fusca type) forests, with minor components of Phyllocladus, 
Podocarpus spp. and Coprosma spp. On low-lying areas, warm temperate beech (Nothofagus brassi type) forests were common, which often contained Laurelia novaezelandiae and Dacrycarpus dacrydioides in areas with impeded drainage and, in areas with better drainage, Dacrydium cupressinum type. In coastal areas, woodland forests of Metrosideros spp. and Casuarinaceae spp. were common.

Although no new direct information on the history of north-western Wairarapa between the latest Early Cretaceous and Middle Miocene was determined in this study, the apatite fission-track results suggest that little to no sedimentation occurred in the region between $36-25 \mathrm{Ma}$ and $11 \mathrm{Ma}$, as cooling of the basement strata as a result of uplift and erosion occurred over this time. 


\section{Acknowledgements}

First and foremost I would like to thank my supervisors, Mike Hannah, John Collen and Diane Seward. Mike, thank you for teaching me the palynological processing technique and for your patience with editing the numerous floral discussion attempts. John, your help with all aspects of this thesis were hugely appreciated. Thank you for your continued guidance and patience throughout this study. Your positive attitude made completing this thesis that little bit easier. Diane, thank you for teaching me about fission-track analysis. Your help with processing, counting and editing (and formatting!) was greatly appreciated.

Thank you to those who voluntarily gave up their own time to help with some aspect of this thesis - Aline, Ben, Jiao, Matt, Katie and Joe. Aline, you have been an enormous help. Thank you for your work with the fossil leaves and for helping me understand the vegetation reconstructions a little better. Ben, you have been a huge help with the stratigraphy aspect. Thank you for your assistance in the field, and for your help with editing. I know how busy you are so it was very much appreciated!

To Mark Rowden, Tracey Rowden and Vaughan Marfell, thank you for being kind enough to allow me to access your properties, it was very much appreciated.

My colleagues, thank you for the welcomed distractions, you guys have been awesome! What a great bunch of people to share this experience with.

Finally, to my family and friends, without your continued support I would not be where I am today. So thank you all - Mum, Dad, Grandma, Callum, Bryce, Lyndal and Hakopa. 


\section{Table of Contents}

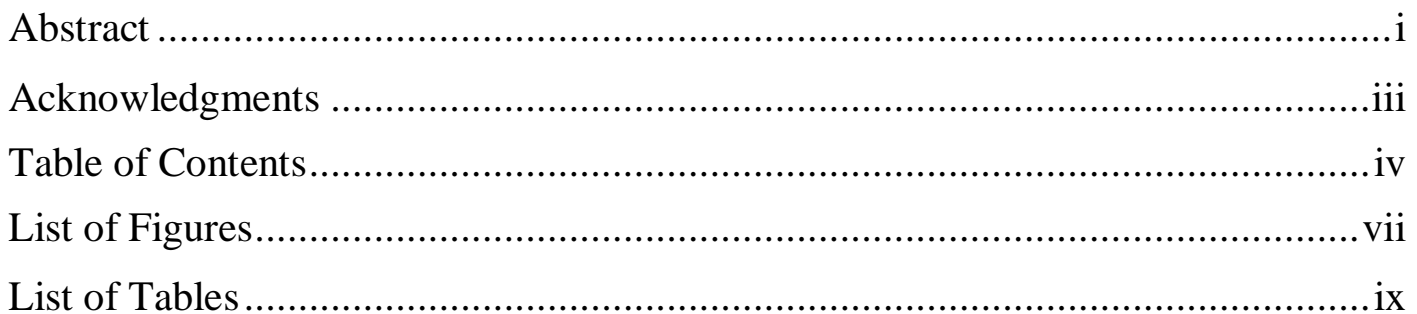

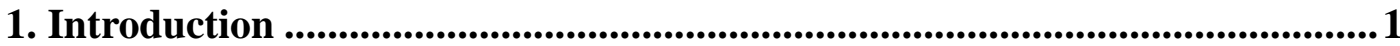

1.1. General introduction ....................................................................... 1

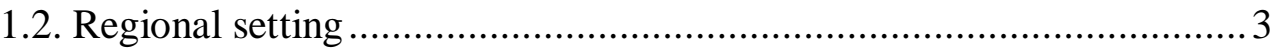

1.3. Mangaoranga Formation ................................................................. 5

1.3.1. General introduction........................................................ 5

1.3.2. Related work ............................................................. 7

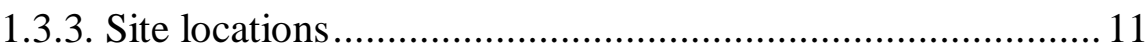

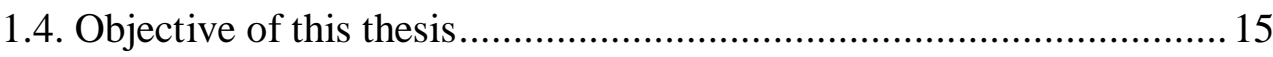

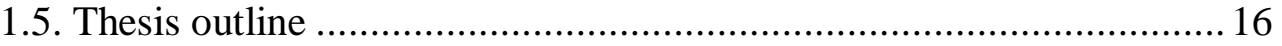

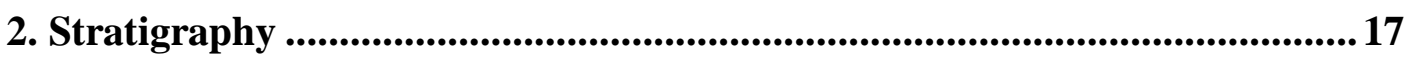

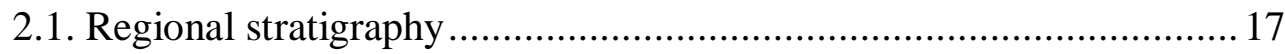

2.2. Stratigraphy of the Mangaoranga Formation .................................. 22

2.2.1. Field work and mapping .............................................. 22

2.2.2. Mangaoranga Stream section........................................ 23

2.2.3. Mauriceville section ......................................................... 35

2.2.4. Central Mangaone Road section ........................................ 37

2.2.5. Mt Bruce section ................................................................. 40

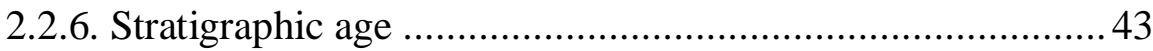

2.2.7. Stratigraphic correlations............................................... 43

2.2.8. Environment of deposition ............................................. 48

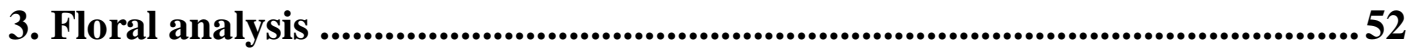

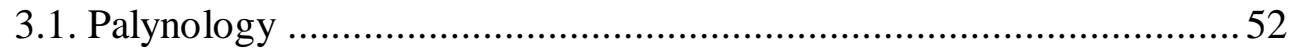

3.1.1. General introduction................................................... 52

3.1.2. Dispersal techniques..................................................53

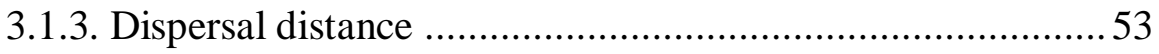




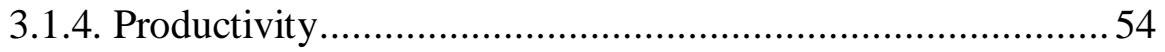

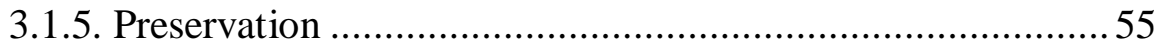

3.1.6. Palynomorphs and vegetation reconstructions .......................55

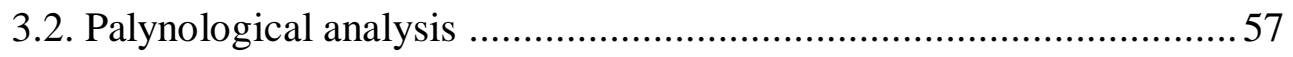

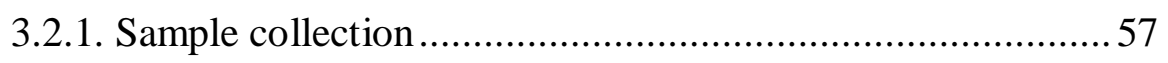

3.2.2. Sample preparation........................................................... 58

3.2.3. Palynology examination and identification ............................5 59

3.2.4. Natural affinities and categorisation ...................................... 59

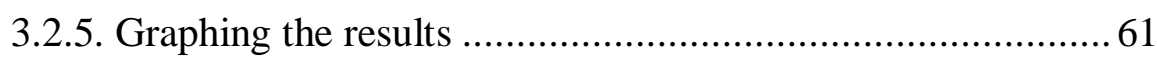

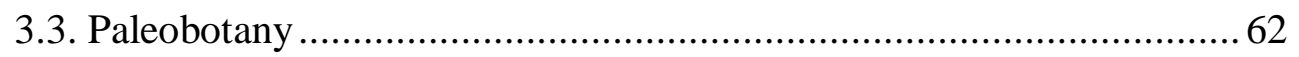

3.3.1. Sample collection and preparation ......................................... 62

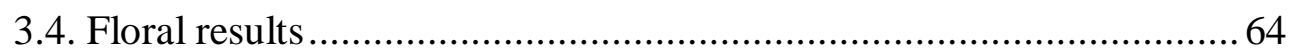

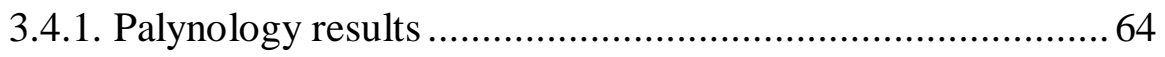

3.4.2. Palynology results summary .............................................. 78

3.4.3. Paleobotany results........................................................... 79

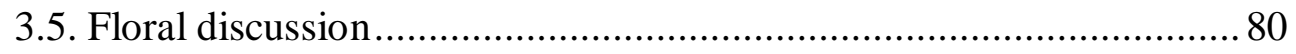

3.5.1. Reconstructing the vegetation cover ...................................... 80

3.5.2. Discussion summary ………………………………....... 108

3.5.3. Fossil palynomorphs and age constraints .............................110

4. Fission-track analysis ............................................................................................ 111

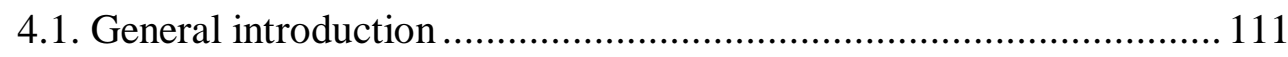

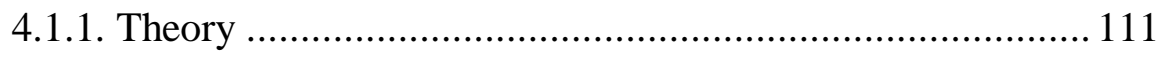

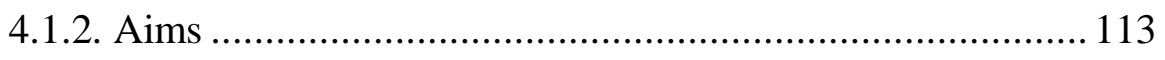

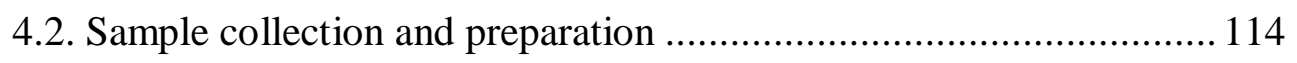

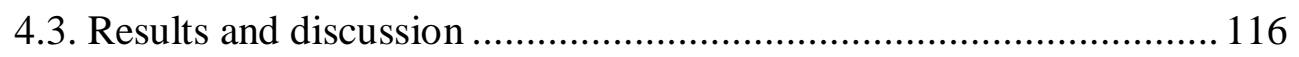

5. Geological evolution ..........................................................................................120

5.1. Summary of the Permian to Miocene geological evolution of

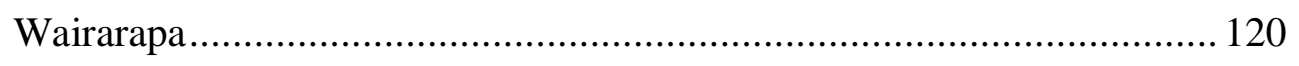

5.1.1. Permian - Early Cretaceous................................................ 120

5.1.2. Early Cretaceous - Oligocene ............................................ 120

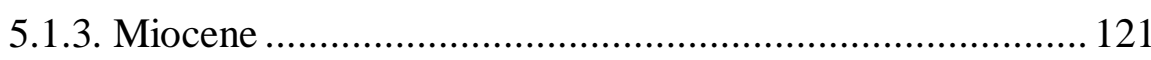

5.2. Upper Miocene geological evolution of north-western Wairarapa .... 123

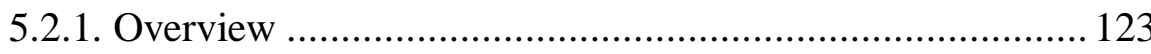


5.2.2. Basement burial and exhumation

5.2.3. Tongaporutuan sedimentation (Mangaoranga Formation) .. 124

5.2.4. Correlations to the wider Wairarapa region

5.2.5. Vegetation cover

5.2.6. Kapitean sedimentation (Kaiparoro Formation)

5.3. Summary of the Pliocene to Quaternary geological evolution of Wairarapa

5.3.1. Pliocene - Early Pleistocene.

5.3.2. Quaternary

5.4. Implications

Conclusions 134

Reference List 136

Appendices 149

Appendix 1.1. Palynological processing techniques 150

Appendix 1.2. Taxonomic lists 160

Appendix 1.3. Pollen plates 172

Appendix 2.1. Fission-track processing technique 178 Appendix 2.2. Fission-track data 182 


\section{Chapter 1}

1.1 Regional setting of the Wairarapa region .......................................... 3

1.2 Outcrops of the Mangaoranga Formation ............................................ 5

1.3 Mangaoranga Formation stratigraphic column (after Neef, 1984).........9

1.4 Mangaoranga Stream site location map .......................................... 12

1.5 Central Mangaone Road site location map ...................................... 13

1.6 Mauriceville site location map .................................................... 14

\section{Chapter 2}

2.1 Generalised regional stratigraphic columns ..................................... 20

2.2 Mangaoranga Stream geological map ........................................... 23

2.3 Mangaoranga Stream measured section …....................................... 24

2.4 Features of the lower conglomerate unit ......................................... 26

2.5 Features of the interbedded sandstone and mudstone unit .................. 28

2.6 Features of the upper conglomerate unit .......................................... 30

2.7 Features of the sandstone unit ......................................................... 32

2.8 Features of the siltstone unit ............................................................ 33

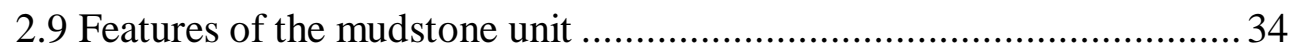

2.10 Mauriceville section geological map ............................................. 35

2.11 Mauriceville section stratigraphic column ...................................... 36

2.12 Central Mangaone Road section geological map ............................. 37

2.13 Central Mangaone Road section stratigraphic column ...................... 39

2.14 Mt Bruce section geological map ................................................ 40

2.15 Mt Bruce section stratigraphic column .......................................... 42

2.16 Mangaoranga Formation member correlations .............................. 47

\section{Chapter 3}

3.1 Diagram of vegetation relationships with respect to site diameter .......56

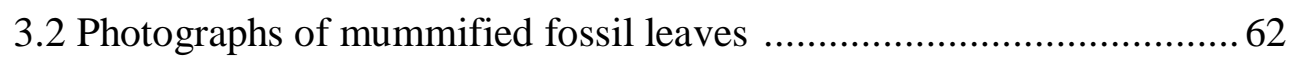

3.3 Pollen and spore assemblages for the Mangaoranga Formation ........... 66

3.4 Arboreal pollen assemblages for the Mangaoranga Formation ...........67

3.5 Schematic vegetation reconstruction of the Alfredton area................. 87 
3.6 Schematic vegetation reconstruction of the Central Mangaone Road area

3.7 Schematic vegetation reconstruction of the Mangaoranga Stream area, from samples KH1308a and KH1308b

3.8 Schematic vegetation reconstruction of the Mangaoranga Stream area, from sample KH1312

3.9 Schematic vegetation reconstruction of the Mangaoranga Stream area, from sample KH1313

3.10 Schematic vegetation reconstruction of the Mangaoranga Stream area, from sample KH1308c

3.11 Schematic vegetation reconstruction of the Mangaoranga Stream area, from sample KH1314.... 101

3.12 Schematic vegetation reconstruction of the Mauriceville area, from sample KH1307.

3.13 Schematic vegetation reconstruction of the Mauriceville area, from samples KH1306 and KH1309

3.14 Schematic vegetation reconstruction of the Mt Bruce area

\section{Chapter 4}

4.1 Schematic illustration of the thermal evolution of the basement strata

\section{Chapter 5}

5.1 Late Miocene paleogeography of north-western Wairarapa.

5.2 Generalised reconstruction of the Late Miocene vegetation cover of north-western Wairarapa 


\section{List of Tables}

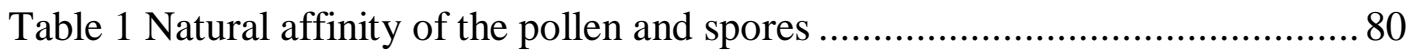

Table 2 Fission-track data table ....................................................................... 119 


\section{CHAPTER 1}

\section{Introduction}

\subsection{General introduction}

Much of Wairarapa, New Zealand was submerged during the Neogene, with marine sedimentary sequences being deposited on top of the underlying Mesozoic and Paleogene landscape (Lee \& Begg, 2002). Today in parts of central and eastern Wairarapa, Paleogene to Quaternary strata are preserved in an almost complete sedimentary sequence overlying Mesozoic Torlesse basement. In western Wairarapa, however, Early Cretaceous to Late Miocene sedimentary deposits are absent from the stratigraphic record, resulting in a poorly understood geological evolution of this region over this period.

In parts of north-western Wairarapa, scarce Upper Miocene strata are exposed immediately overlying Mesozoic Torlesse basement. These strata consist of both marine and non-marine sequences which collectively make up the Mangaoranga Formation. The strata of the Mangaoranga Formation are the oldest rocks preserved directly overlying Mesozoic basement in this region and thus provide an opportunity to study the geological evolution of north-western Wairarapa during the Late Miocene.

Previous investigations of the Mangaoranga Formation have been primarily focused on mapping the formation in detail based on basic lithological descriptions, and little work has been focused on examining the stratigraphy in detail. As a result, previous interpretations of the Late Miocene geological evolution of north-western Wairarapa are very generalised. 
The present study attempts to extend the current understanding of the Late Miocene geological evolution of north-western Wairarapa by mapping, sampling, and examining in detail the strata of the Mangaoranga Formation at three separate localities and utilising data from other studies in the region. Samples collected for palynological analysis and fossil leaves found within the formation provide an opportunity to study the flora of north-western Wairarapa during the period of deposition. In addition, samples collected for fission-track analysis from the underlying Torlesse strata allow the cooling history and hence exhumation rates of the basement rocks to be analysed, which aids investigations of the burial history of overlying strata. The results of these analyses, in conjunction with detailed lithological descriptions, allow floral and paleogeographic interpretations of northwestern Wairarapa during the Late Miocene to be made. 


\subsection{Regional setting}

The Wairarapa region is located on the eastern side of the southern North Island, New Zealand. The region forms part of the Hikurangi margin plate-boundary zone, which accommodates oblique convergence between the Australian and Pacific plates (Figure 1.1). The plate-boundary margin, marked by the Hikurangi Trough, is located 65 to $125 \mathrm{~km}$ offshore to the east of the Wairarapa region (Lee \& Begg, 2002).

Onshore, the region is bound to the west by the uplifted axial ranges (Figure 1.1). To the east of the ranges is a forearc basin (Wairarapa Depression) and outer arc high (East Coast Highlands) respectively (Lamarche et al., 1995). The region is cut by a series of large fault systems, accommodating both compressional and transcurrent motion.

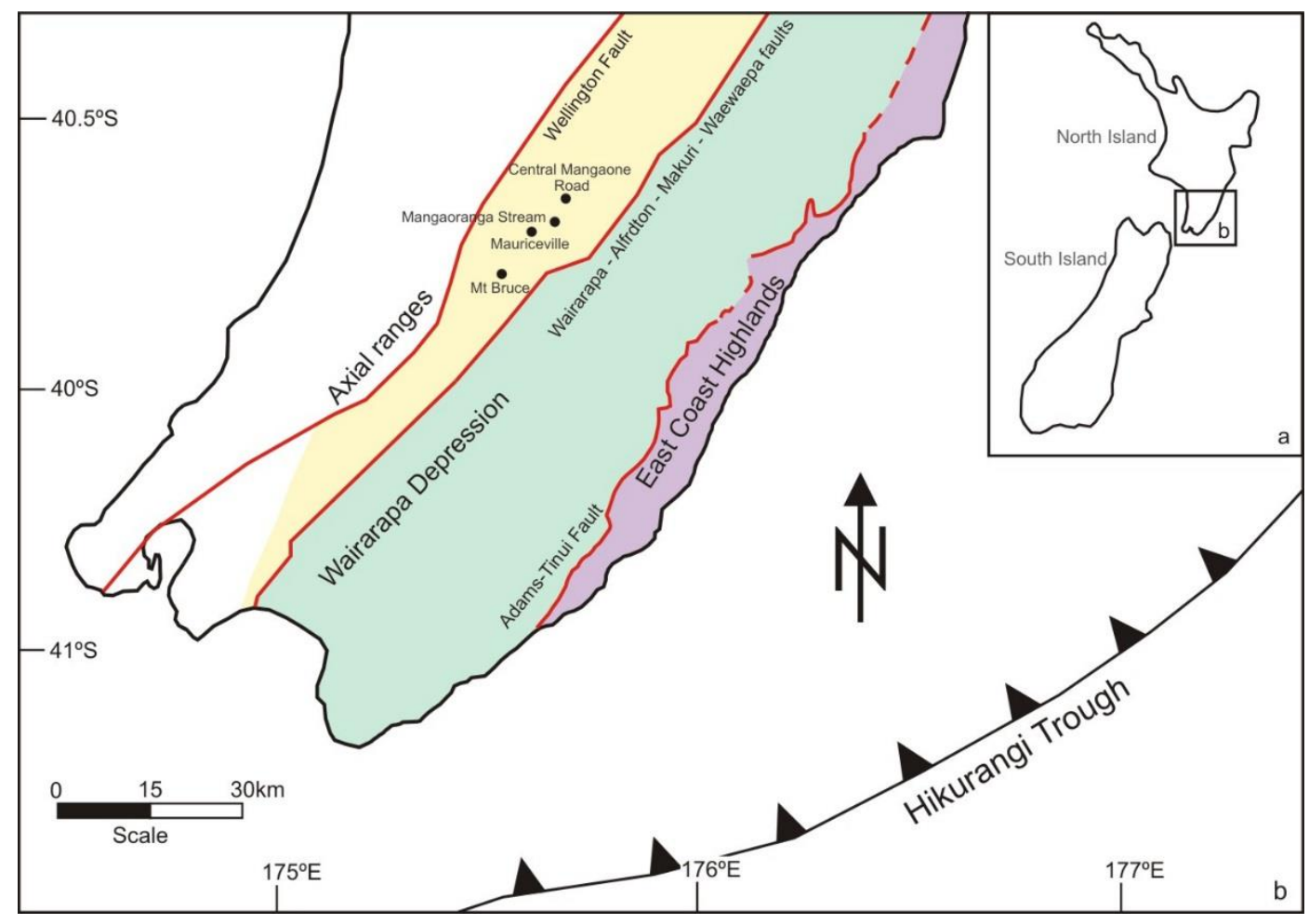

Figure 1.1: Regional setting of Wairarapa: a) general location of the Wairarapa region with respect to New Zealand and b) enlarged area of the lower North Island, highlighting the major geographic and tectonic features. 
To describe the distribution of rocks in Wairarapa, the region is divided into three distinct geographical divisions: western Wairarapa (west of the Wairarapa, Alfredton, Makuri and Waewaepa faults), central Wairarapa (east of the Wairarapa, Alfredton, Makuri and Waewaepa faults, west of the Adams-Tinui Fault), and eastern Wairarapa (east of the Adams-Tinui Fault) (Figure 1.1, adapted from Lee \& Begg, 2002).

In parts of central and eastern Wairarapa, Early Cretaceous to Quaternary rocks are preserved in an almost complete sedimentary sequence overlying Mesozoic greywacke basement. The preservation of these sequences has allowed for a comprehensive understanding of the evolution of these areas since the Early Cretaceous.

In western Wairarapa, there is a major unconformity in the stratigraphic record representing the later Cretaceous, the Paleogene and part of the Neogene. The absence of rocks of this age has resulted in a limited understanding of the evolution of western Wairarapa during this time. However, in areas of north-western Wairarapa, Late Miocene marine and non-marine deposits are preserved immediately overlying Mesozoic greywacke basement. These deposits make up the Mangaoranga Formation and provide an opportunity to examine the geological evolution of north-western Wairarapa during part of the late Neogene. 


\subsection{Mangaoranga Formation}

\subsubsection{General introduction}

The Mangaoranga Formation (Neef, 1984) is composed of marine and non-marine conglomerate, mudstone, siltstone, sandstone and carbonaceous beds. The formation immediately overlies Mesozoic greywacke basement in areas of north-west Wairarapa and trends northeast-southwest over $80 \mathrm{~km}$, extending north from Carrington, west of Carterton, to the south-western flanks of the Waewaepa Range (Figure 1.2). The eastern limit of the formation is not clearly defined; however, Lee \& Begg (2002) place the boundary along the Wairarapa, Dreyers rock, Alfredton and Makuri-Waewaepa faults. The westernmost exposure of the formation is located along the eastern side of Wellington fault, $8 \mathrm{~km}$ west of Eketahuna (Neef, 1984).

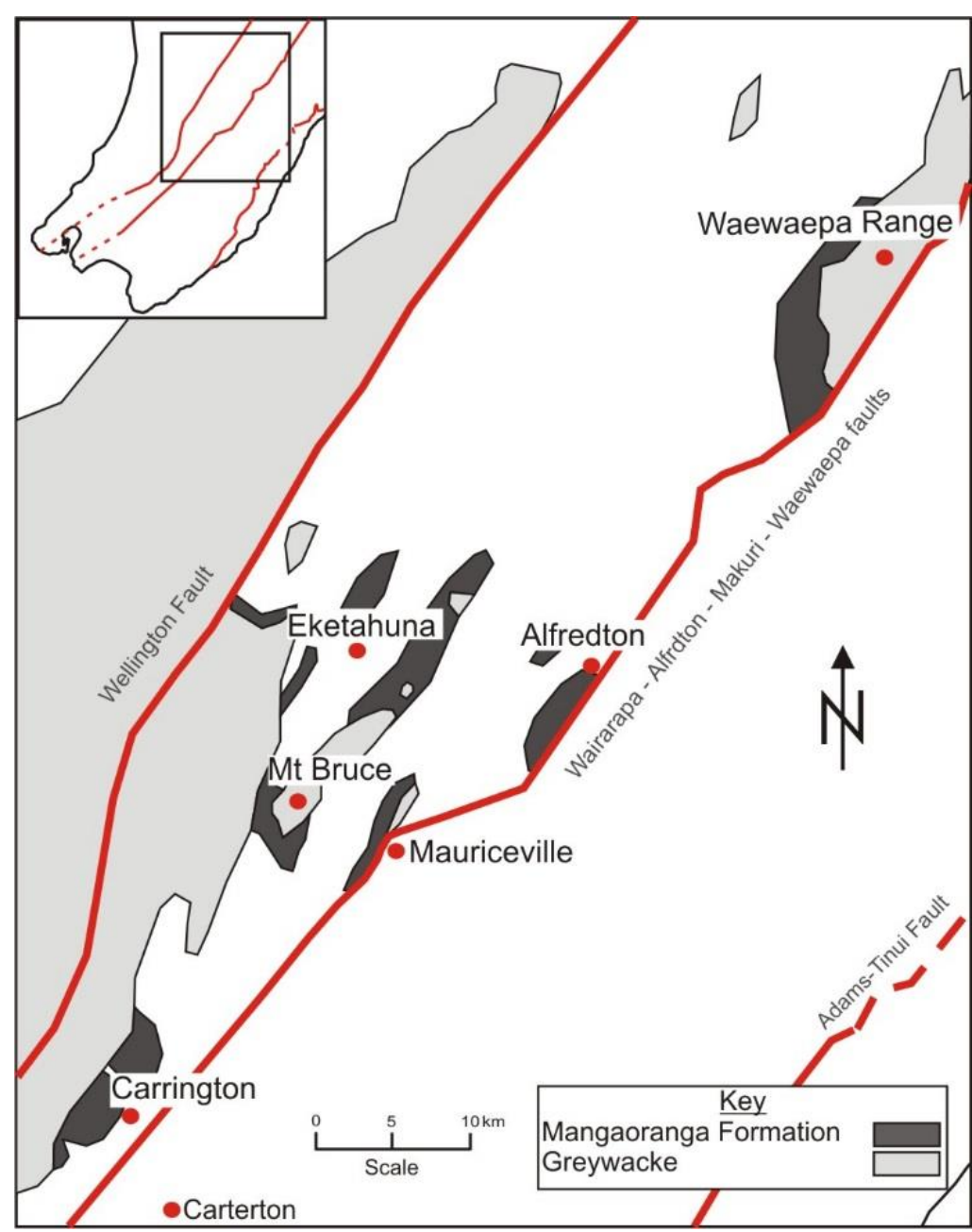

Figure 1.2: Outcrops of the Mangaoranga Formation in northwest Wairarapa. 
The deposits of the Mangaoranga Formation are the oldest preserved directly overlying Mesozoic greywacke basement in western Wairarapa. An age of Tongaporutuan (11 - $7 \mathrm{Ma}$ ) has been suggested for the formation based on analyses of fossil pollen and marine macrofauna (Neef, 1984; Wells, 1985). However, this age cannot be constrained further due to the absence of datable marker horizons. 


\subsubsection{Related work}

Previous work carried out in relation to the Mangaoranga Formation includes mapping and stratigraphic descriptions, coal seam investigations and several palaeontological and palynological analyses.

The earliest work carried out on the formation was by McKay (1896), who first examined the lignitic seams in the then un-named Mangaoranga Formation as possible fuel for locomotives. McKay examined the seams at three separate localities around north-western Wairarapa, 1) Maharahara, near Woodville, 2) Mauriceville and 3) the Tiraumea Estate, $21 \mathrm{~km}$ east of Alfredton, and described the enclosing sediments as gravels, clays and sands, beneath fossiliferous marine sediments. After careful examination, McKay concluded that the lignitic seams were of varying quality and not of an economic thickness, and thus the seams and enclosing sediments were not investigated further.

Detailed mapping and basic stratigraphic descriptions of the formation were carried out by Orbell (1961) in the Mauriceville District, Neef (1984) in the Eketahuna District, Wells (1985) in the Mt Bruce area and Wells (1989a) in the Carrington area (Figure 1.2).

Orbell (1961) mapped the deposits of the formation in part of the Mauriceville District based on very general lithological descriptions. He described a basal conglomerate cropping out directly above greywacke basement, overlain by carbonaceous shale, non-marine mudstone, conglomerate, fossiliferous sandstone and finally blue-grey marine mudstone respectively. He sampled the carbonaceous shale for pollen analysis, and also analysed macrofossils in the overlying fossiliferous sandstone. His pollen results indicated a Kapitean (possibly Tongaporutuan) age for the shale, with flora from mixed warm and cold environments. The macrofossil assemblage supported a Kapitean age.

Neef (1984) mapped the deposits of Mangaoranga Formation in the Eketahuna region, where he defined the upper and lower stratigraphic boundaries of the formation. He formally named the formation after the type section in Mangaoranga Stream, and subsequently grouped it into the Soren Group, along with the overlying 
Kaiparoro Formation. Neef defined five members of the Mangaoranga Formation cropping out in Mangaoranga Stream, and assigned individual codes to each (Figure 1.3). The basal unit of the formation was described as a $35 \mathrm{~m}$ thick greywacke breccia, overlain by a thin layer of conglomerate. Overlying this Neef described a 35 $\mathrm{m}$ thick sequence of marl $\left(\mathrm{sm}_{2}\right)$, which was itself overlain by a $120 \mathrm{~m}$ thick sequence of marine and non-marine conglomerate $\left(\mathrm{sm}_{1}\right)$. The $\mathrm{sm}_{1}$ sequence was overlain by a $155 \mathrm{~m}$ thick sequence of marine sandstone, coded $\mathrm{sm}_{3}$, followed by a $30 \mathrm{~m}$ thick sequence of siltstone $\left(\mathrm{sm}_{4}\right)$. The final member of the Mangaoranga Formation described at this location was a $245 \mathrm{~m}$ thick sequence of mudstone $\left(\mathrm{sm}_{5}\right)$. Neef analysed two macrofaunal assemblages collected from the fossiliferous sandstone $\left(\mathrm{sm}_{3}\right)$, as well as a sample collected for pollen analysis from $\mathrm{sm}_{2}$. He found that the macrofaunal assemblages indicated an age for the formation of Tongaporutuan, while the results of the pollen analysis were very poor, with fern spores dominating the assemblage. Neef also briefly described the depositional environment for each member. He described the breccia as forming from physical erosion (as opposed to chemical), while the marl $\left(\mathrm{sm}_{2}\right)$ represented deposition in the abandoned meander of a river. The conglomerate $\left(\mathrm{sm}_{1}\right)$ was interpreted as fluvial and the sandstone $\left(\mathrm{sm}_{3}\right)$, siltstone $\left(\mathrm{sm}_{4}\right)$ and mudstone $\left(\mathrm{sm}_{5}\right)$ as the deposits of a marine transgression.

Wells (1985) described a sequence in the Ruamahanga River, Mt Bruce area, similar to that of Neef (1984) in Mangaoranga Stream and was able to correlate the members at the two sites based on the lithological descriptions. Wells adopted Neef's coding system to describe each member, where she defined a new basal member, $\mathrm{sm}_{0}$ (Moles Mudstone) in place of Neef's $\mathrm{sm}_{1}$ (conglomerate) and overlying $\mathrm{sm}_{2}$ (marl) members. The Moles Mudstone member was overlain by $\mathrm{sm}_{1}$ (conglomerate), $\mathrm{sm}_{3}$ (sandstone), $\mathrm{sm}_{4}$ (siltstone) and $\mathrm{sm}_{5}$ (mudstone). The Moles Mudstone member contained poorly preserved pollen indicating a Tongaporutuan age and vegetation from warm temperate forests and cool temperate uplands. A macrofaunal assemblage collected near the top of Moles Mudstone supported the age of Tongaporutuan and suggested that deposition of the mudstone occurred in an estuarine environment. The conglomerate $\left(\mathrm{sm}_{1}\right)$, was interpreted as being the deposits of a coastal alluvial fan while the overlying sandstone $\left(\mathrm{sm}_{3}\right)$, siltstone $\left(\mathrm{sm}_{4}\right)$ and mudstone $\left(\mathrm{sm}_{5}\right)$ was interpreted as being deposited by a marine transgression. 
Mangaoranga Formation - Mangaoranga Stream (Neef, 1984)
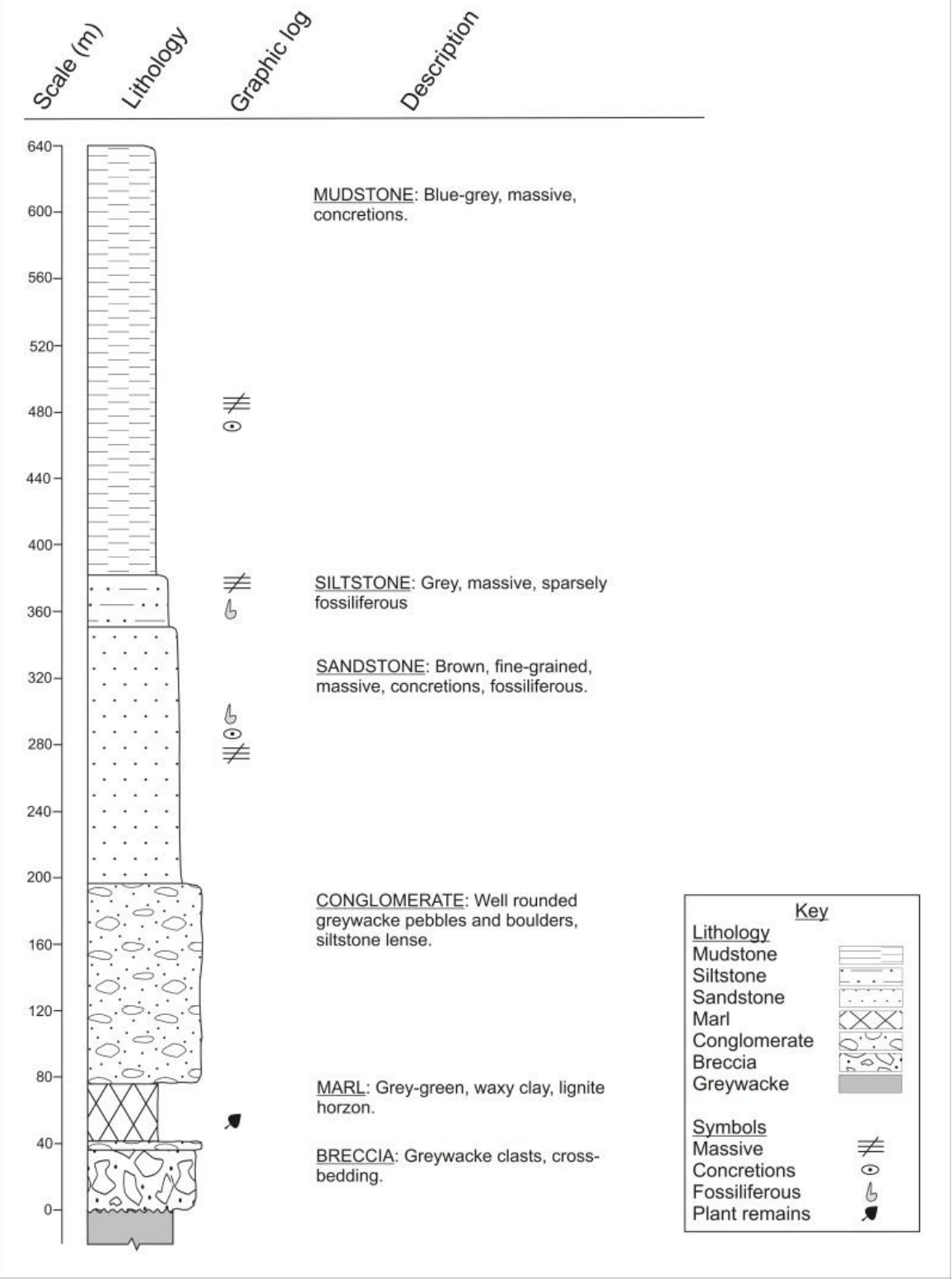

Figure 1.3: Stratigraphic column of the Mangaoranga Formation at Mangaoranga Stream, Eketahuna. After Neef (1984).

Wells (1989a) mapped in detail and described the Mangaoranga Formation in its southernmost exposure, at Carrington, west of Carterton. She correlated each member to those described by Neef (1984) in Mangaoranga Stream and assigned a Tongaporutuan age to the formation, based on the stratigraphic relationship with the overlying sediments. She estimated the thickness of the formation as $1200 \mathrm{~m}$ at this 
location, which included $500 \mathrm{~m}$ of $\mathrm{sm}_{1}$ (conglomerate), $300 \mathrm{~m}$ of $\mathrm{sm}_{3}$ (sandstone), $100 \mathrm{~m}$ of $\mathrm{sm}_{4}$ (siltstone) and $250 \mathrm{~m}$ of $\mathrm{sm}_{5}$ (mudstone).

Despite efforts in these previous studies to map and briefly interpret the environment of deposition the Mangaoranga Formation, there is still lack of detailed understanding of the evolution of north-western Wairarapa during this period. 


\subsubsection{Site locations}

Three separate exposures of Mangaoranga Formation were examined in this study for stratigraphic, palynological and fission-track analysis. The localities were chosen where both the Mangaoranga Formation and underlying Torlesse strata cropped out at the surface. The three sites are:

1) The Mangaoranga Stream section, Eketahuna

2) The Central Mangaone Road section, Eketahuna

3) The Mauriceville section, Mauriceville

Samples available for pollen analysis from two other locations, in the Mt Bruce and Alfredton areas, were also examined (Figure 1.2). 
Mangaoranga Stream section

The Mangaoranga Stream section (Figure 1.4) is the type section for the Mangaoranga Formation. The site is located $1.5 \mathrm{~km}$ southeast of the Eketahuna Township, on privately owned pastureland. The section is primarily exposed along the banks of Mangaoranga Stream, and is bounded on the eastern side by the westward-dipping Mount Bowen Fault. Minor exposures of the section are located along Mangaoranga Road, as well as on the scarp of a recent landslide. Most of the section is well exposed; however, parts are obscured by vegetation and landslide debris. The topography in this study area is mostly flat; with hills on either side of the stream reaching a maximum relief of $140 \mathrm{~m}$.

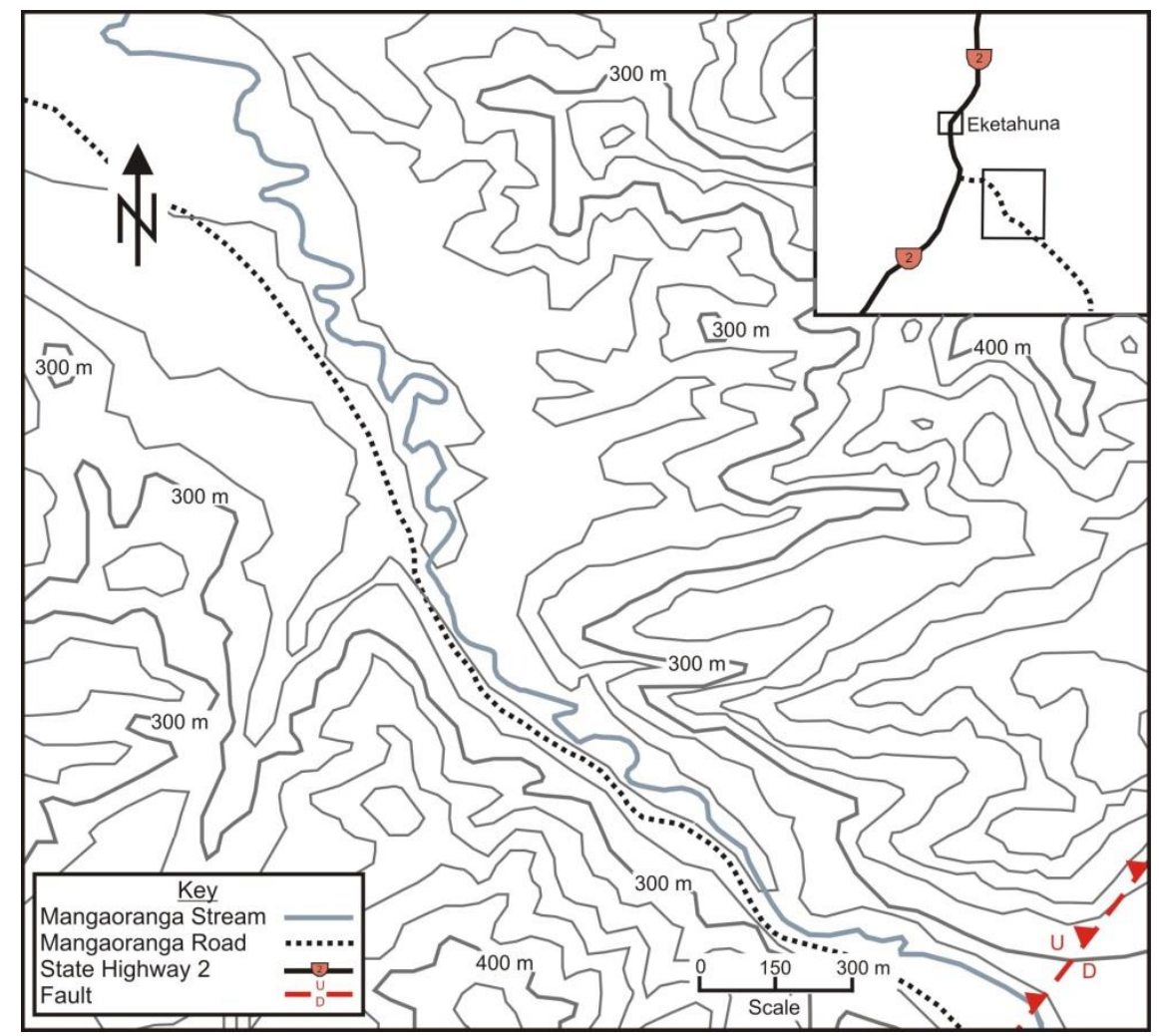

Figure 1.4: Map of the Mangaoranga Stream section. Contour interval is $20 \mathrm{~m}$. 


\section{Central Mangaone Road section}

The Central Mangaone Road section (Figure 1.5) is the northernmost section examined in this study. The site is located $5 \mathrm{~km}$ northeast of Eketahuna, along Central Mangaone Road. Similarly to the Mangaoranga Stream section, the site is bounded to the east by Mount Bowen Fault. The section outcrops along the Central Mangaone Road side; however, exposure is poor due to weathering and vegetation overgrowth. The topography at this site is fairly hilly, with a maximum relief of 140 m.

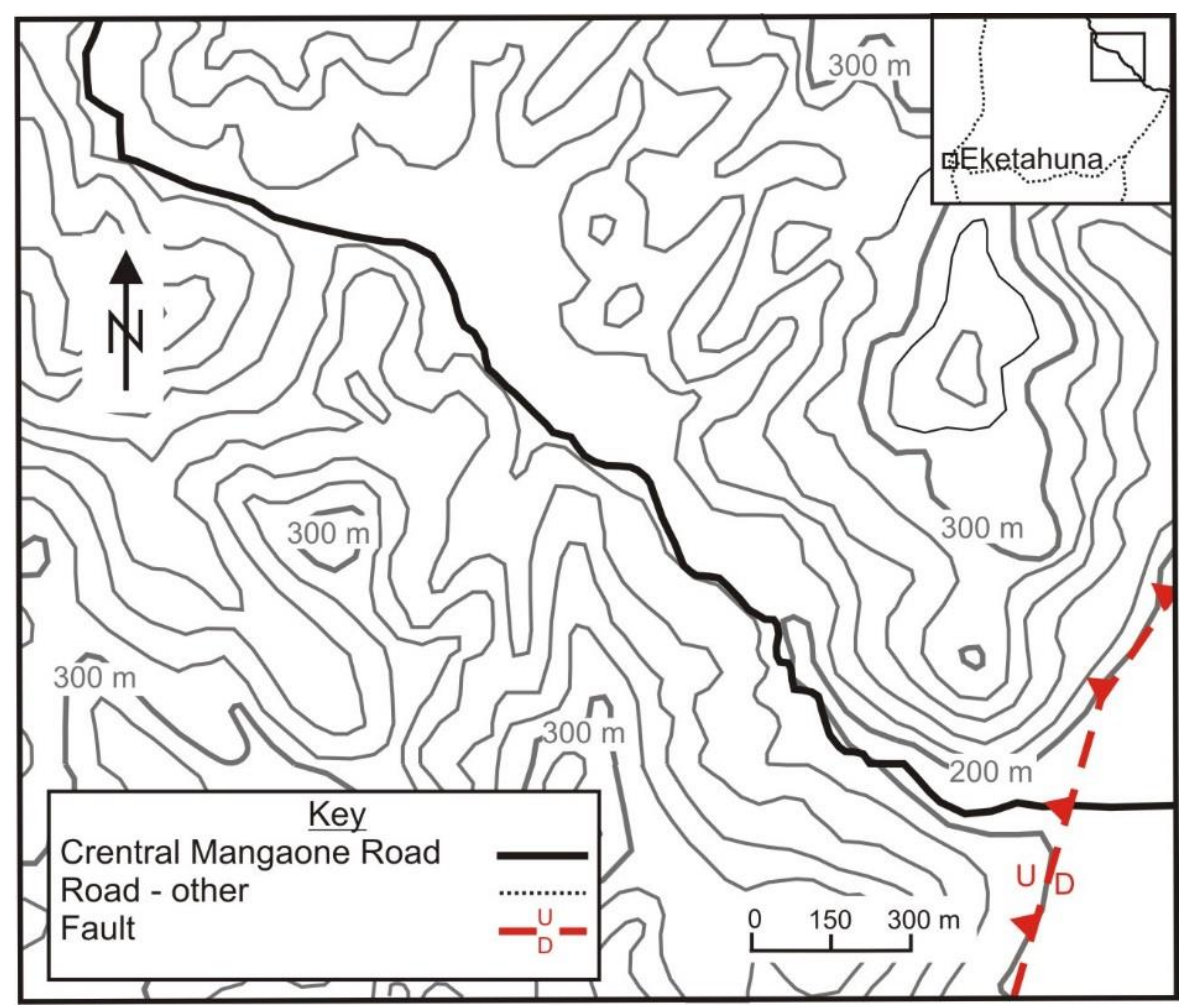

Figure 1.5: Map of the Central Mangaone Road section. Contour interval is $20 \mathrm{~m}$. 


\section{Mauriceville section}

The Mauriceville section (Figure 1.6) is located $1.8 \mathrm{~km}$ north of the Mauriceville settlement and contains the southernmost strata examined in this study. The study area consists of hilly pasturelands, with a maximum relief of $100 \mathrm{~m}$. It is bounded on the eastern side by a westward-dipping splay of the Wairarapa Fault. The strata are located on privately owned farmland, where exposure of the formation occurs dominantly along a farm track, and occasionally in places of recent erosion on the hillsides. Outcrops are scarce as most of the area is vegetated and, where exposed strata are, they are generally very weathered. Two abandoned adits are located by the stream on the eastern side of the study area.

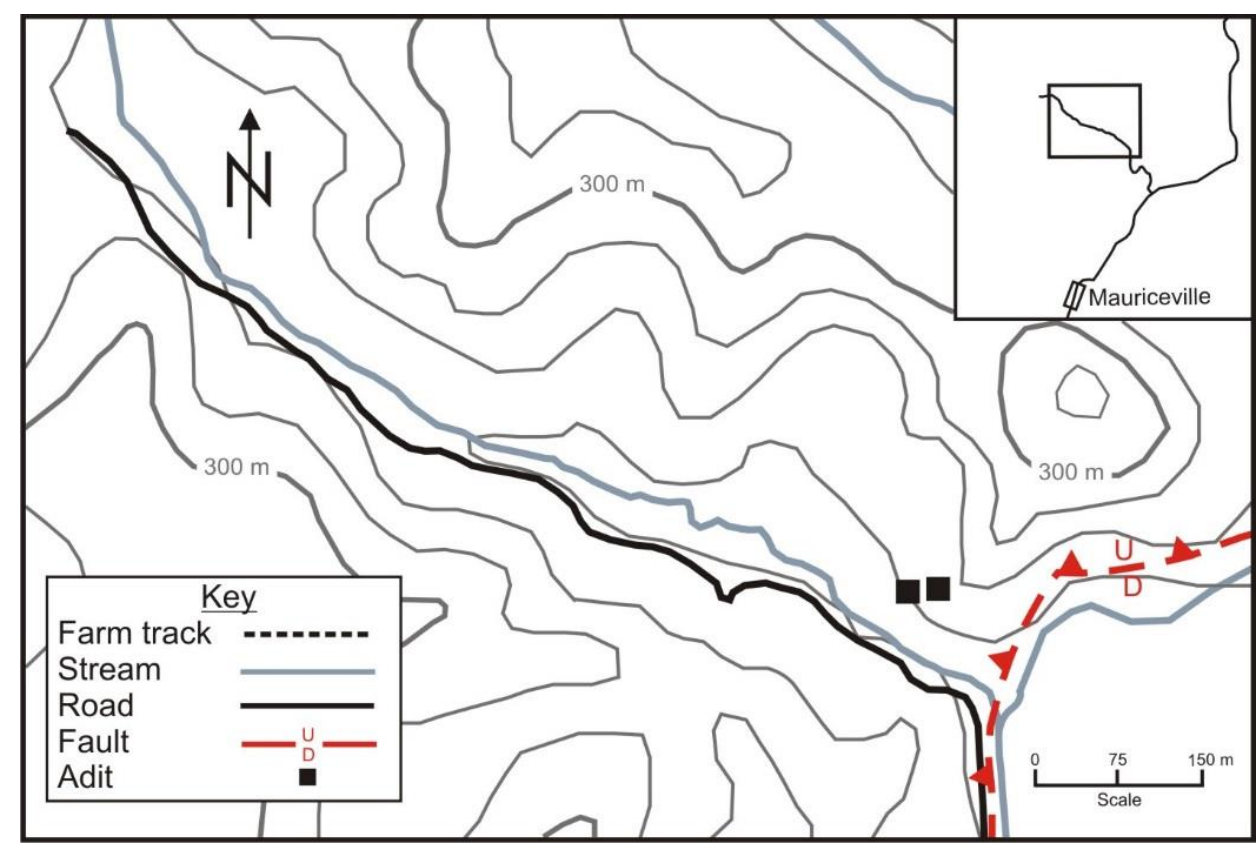

Figure 1.6: Map of the Mauriceville section. Contour interval is $20 \mathrm{~m}$. 


\subsection{Objectives of this thesis}

This study is an attempt to determine the flora and paleogeography of the northwestern Wairarapa region during the Late Miocene by sampling and examining the Upper Miocene deposits of the Mangaoranga Formation at three separate localities. Specifically, the aims are to:

1) Describe the stratigraphy of the Mangaoranga Formation at the type section (Mangaoranga Stream) and subsequently correlate these strata to those at previously described localities. The results from the stratigraphic investigations will aid in the paleogeographic reconstruction of northwestern Wairarapa during the Late Miocene;

2) Determine the Late Miocene flora of north-western Wairarapa by examining fossil pollen, spores and leaves. The results from the floral investigation will also aid in regional altitiudinal estimations as well as general climatic interpretations;

3) Reconstruct the cooling (and hence exhumation) history of the Torlesse strata from fission-track analysis;

4) Investigate the burial history of the formation using information from both the fission-track analysis and the regional stratigraphy; and

5) Combine the results to interpret the depositional history, vegetation and regional paleogeography of the north-western Wairarapa during the Late Miocene. 


\subsection{Thesis outline}

This thesis is composed of six chapters. Chapter one outlines the purpose of this study, introduces the study areas and summarises the thesis objectives. Chapter two discusses both the regional stratigraphy of Wairarapa as well as the stratigraphy of the Mangaoranga Formation. The measured section results of this study are summarised in this chapter, as well as an interpretation of the environment of deposition. Chapter three outlines the palynological methods and results of this study. A discussion of these results is provided thereafter. Chapter four summarises the fission-track methods, results and interpretation. Chapter five combines the interpretations made in chapters two, three and four to summarise the Late Miocene paleogeography and flora of north-west Wairarapa. The conclusions of this study are summarised thereafter. 


\section{CHAPTER 2}

\section{Stratigraphy}

\subsection{Regional stratigraphy}

The Wairarapa region is comprised of Middle Jurassic to Quaternary rocks largely preserved in northeast-southwest trending belts. The rocks are dominated by marine sedimentary sequences which are occasionally separated by significant unconformities. Nowhere in the Wairarapa region is there a complete sedimentary sequence preserved.

The rocks of the Wairarapa region are divided into four major stratigraphic units (adapted from Lee \& Begg, 2002):
i) Middle Jurassic to Early Cretaceous
ii) Early Cretaceous to Oligocene
iii) Miocene to Pliocene
iv) Quaternary

\section{$\underline{\text { Late Jurassic to Early Cretaceous }}$}

\section{Torlesse Supergroup}

The oldest rocks to crop out in the Wairarapa region are Middle Jurassic to Early Cretaceous indurated sandstone and argillite, collectively referred to as 'greywacke' throughout the present study (Figure 2.1). These rocks form part of the Torlesse Supergroup and are similar to those that form the Axial Ranges of the southern North Island (Carter et al., 1978). They consist of dull grey (weathering red-brown) quartzofeldspathic sandstone and argillite with minor components of basalt, conglomerate, chert, coloured argillite and limestone (Moore \& Speden, 1979). The rocks are highly fractured and commonly contain quartz and calcite veins. Because of extensive deformation, the true thickness of the supergroup is unknown, but is thought to be several thousands of meters thick (Neef, 1984). In the Wairarapa region, the supergroup has been divided into five units based on age, petrology, 
geochemistry and isotope geochemistry: the Rakaia terrane, Esk Head belt, Pahau terrane, Waioeka terrane and Pahaoa Group (e.g. Bradshaw et al., 1981; Roser et al., 1995). At the three sites where the greywacke was examined in the present study, the rocks are of the Waioeka terrane. The contact between the greywacke and overlying strata is sharp, angular and unconformable.

\section{Early Cretaceous to Oligocene}

The Early Cretaceous to Oligocene sedimentary sequence of the Wairarapa region is divided into two divisions, based on different lithological sequences (Moore, 1988). These divisions outcrop in the central and eastern areas of Wairarapa, and are formally recognised as the Western and Eastern Sub-belts respectively. The sequences do not crop out in western Wairarapa.

In central Wairarapa, Early Cretaceous rocks are overlain unconformably by Early to Late Cretaceous olistostromes and mudstones of the Mangapurupuru Group, which are themselves unconformably overlain by the Late Cretaceous to Paleocene Tinui Group, grouped into four formations containing mudstone, sandstone and limestone (Figure 2.1: Moore \& Speden, 1979; Moore et al., 1986 ). In eastern Wairarapa, alternating sandstone, mudstone and conglomerate of the Glenburn Formation (partly correlable to the Mangapurupuru Group) overlies Early Cretaceous strata; however the nature of the contact is unknown (Moore \& Speden, 1979). The rocks of the Glenburn Formation are themselves conformably overlain by the upper three formations of the Tinui Group (Moore et al., 1986). The oldest formation of this group, the Tangaruhe Formation, does not crop out in eastern Wairarapa (Crampton, 1997). Finally, Eocene to Oligocene mudstone, greensand, glauconitic sandstone and breccia-conglomerate of the Mangatu Group conformably overlie the Tinui Group in parts of both central and eastern Wairarapa (Moore et al., 1986).

\section{Miocene to Pliocene}

\section{Miocene sequence}

Rocks of Miocene age are preserved in each of the three divisions of the Wairarapa region. Within north-western Wairarapa, Late Miocene strata, where present, 
directly overlie rocks of the Torlesse Supergroup, while in central and eastern Wairarapa; Early to Late Miocene strata overlie Late Cretaceous to Oligocene rocks (Figure 2.1). To facilitate descriptions of the strata in each division, the Miocene sequences have been divided into two groups by Lee \& Begg (2002; modified after those of Vella \& Briggs (1971) and Neef (1984)): the Palliser Group, of Early to Late Miocene age in central and eastern Wairarapa, and the Soren Group, of Late Miocene age in western Wairarapa.

\section{Palliser Group}

Early Miocene strata of the Palliser Group are widely distributed throughout both central and eastern Wairarapa. These strata both conformably and unconformably overlie Late Cretaceous to Oligocene rocks and consist dominantly of marine sandstone and mudstone (Vella \& Briggs, 1971; Johnston, 1980; Reid, 1998).

Middle to Late Miocene strata of the Palliser Group are widely distributed in central Wairarapa, but are only locally preserved in eastern Wairarapa. Strata of this age rest both conformably and unconformably on Miocene or older sequences and consist dominantly of massive mudstone with minor alternating sandstone, mudstone, and shelly conglomerate (Beu, 1970; Vella \& Briggs, 1971).

\section{Soren Group}

In parts of north-western Wairarapa, Late Miocene strata, where present, unconformably overlie Middle Jurassic to Early Cretaceous rocks of the Torlesse Supergroup. They were divided into the Soren Group by Neef (1984), containing the Mangaoranga and Kaiparoro formations. The Mangaoranga Formation is between $500 \mathrm{~m}$ and $1200 \mathrm{~m}$ thick and consists mainly of terrestrial conglomerate, mudstone, carbonaceous mudstone, and sandstone (Neef, 1984; Wells, 1989a). The Kaiparoro Formation conformably overlies the Mangaoranga Formation at several localities, and is comprised of shallow marine siltstone, sandstone, conglomerate and limestone (Neef, 1984).

At two of the three localities examined in the present study (Mangaoranga Stream and Central Mangaone Road sections), Kaiparoro Formation conformably overlies the Mangaoranga Formation. At the Mauriceville section, however, Kaiparoro Formation is absent from the stratigraphic record. 


\section{Late Miocene to Early Quaternary}

The Onoke Group consists of the Late Miocene Makara Greensand and basal Mangaopari Mudstone, all Pliocene sediments and the Early Quaternary Hautotara Formation (Vella \& Briggs, 1971; Collen \& Vella, 1984; Crundwell, 1997; Lee \& Begg, 2002). These sequences conformably overlie Late Miocene strata where present, and otherwise rest unconformably on Early Miocene or older strata. In western and eastern-central Wairarapa, strata of the Onoke Group are widespread and well represented in the stratigraphic record, while in eastern Wairarapa they are restricted to the Castlepoint region (Johnston, 1973). The dominant lithology in this group is a massive, blue-grey mudstone, with minor alternating sandstone and mudstone beds, coquina limestone and conglomerate (Figure 2.1). The thickness of the group varies, but is thought to be approximately $1200 \mathrm{~m}$ thick west of the Wairarapa, Alfredton, Makuri and Waewaepa faults, and $2700 \mathrm{~m}$ thick east of these faults (Neef, 1984).

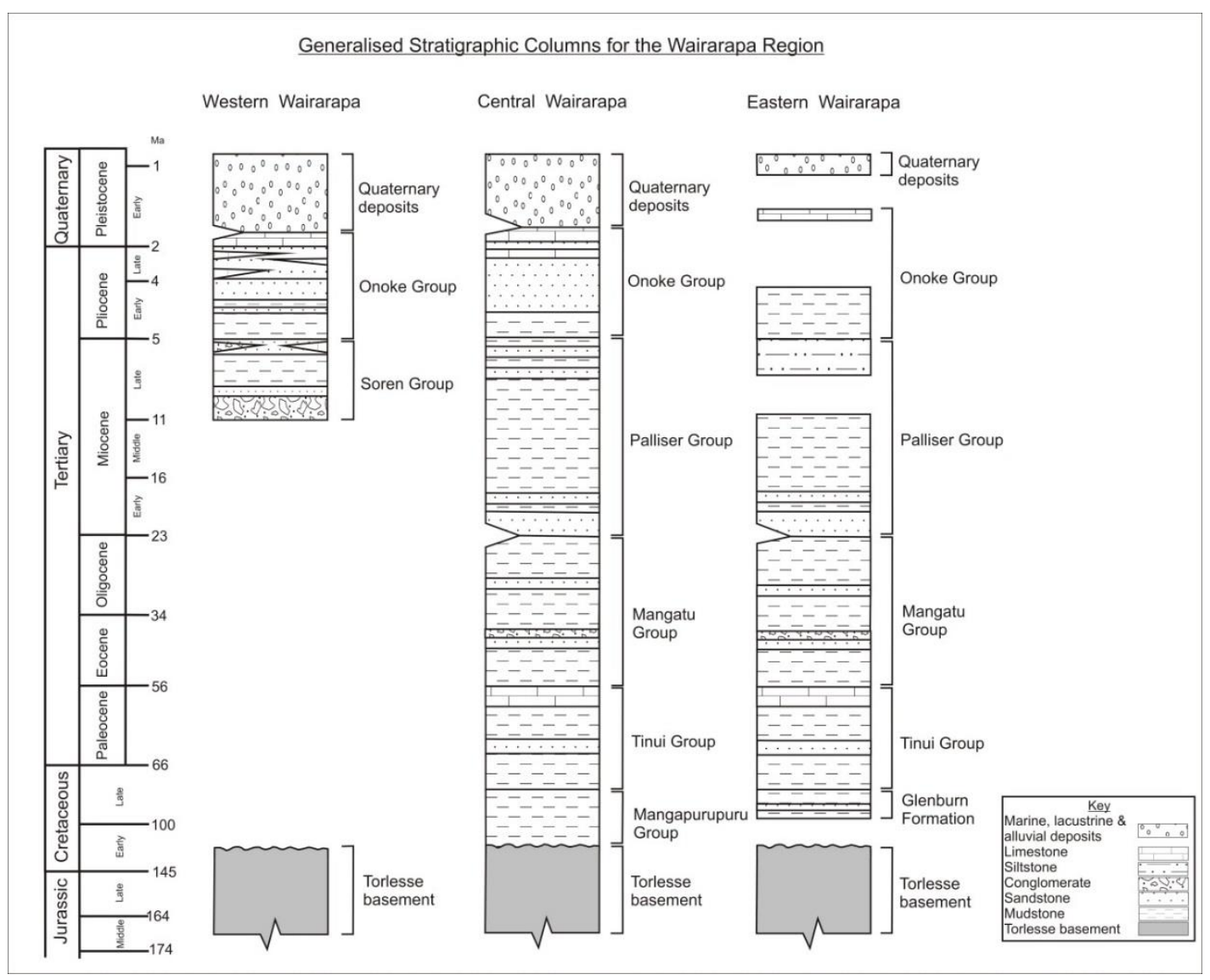

Figure 2.1: Generalised stratigraphic columns for the western, central and eastern areas of the Wairarapa region. Compiled using information from other studies (e.g. Vella \& Briggs, 1971; Neef, 1984; Lee \& Begg, 2000). 


\section{Quaternary}

Quaternary strata in the Wairarapa region consist dominantly of alluvial, marginal marine and lacustrine deposits. In western Wairarapa, Early to Late Quaternary deposits are preserved conformably or unconformably overlying Late Pliocene and Early Pleistocene strata. These deposits dominantly consist of marginal marine sediments and alluvial gravels (Neef, 1984). In central Wairarapa, Early to Late Quaternary deposits are restricted in extent, and are dominated by alluvial and lacustrine sediments (Collen \& Vella, 1984). Early to Middle Quaternary deposits are largely absent in the stratigraphic record in eastern Wairarapa, while Late Quaternary deposits are spatially restricted. 


\subsection{Stratigraphy of the Mangaoranga Formation}

2.2.1. Field work and mapping

Ten days were spent in the field collecting samples, examining the stratigraphy and measuring the formation to produce a detailed measured section of the Mangaoranga Formation. Scarce exposure of the formation at the Mauriceville and Central Mangaone Road sites allowed detailed mapping and stratigraphic descriptions at only one of the three sites - the Mangaoranga Stream site (Figure 1.2). Descriptions of the formation at these other sites relies on information collected in earlier studies, when exposure was better (i.e. Mauriceville section, Orbell (1961); Central Mangaone Road section, Neef (1984)).

A tape and compass method was used to measure the formation in Mangaoranga Stream (Figure 2.2), with descriptions made where strata were exposed along the tape. Where possible, strike and dip measurements were also taken. Sample sites were recorded using GPS coordinates and subsequently included within the measured section. The true thickness of the section was calculated using Dr James Crampton's (GNS Science) 'Sections' program. Sample sites located at the Mauriceville and Central Mangaone Road sections were recorded using GPS coordinates and subsequently plotted onto aerial photographs. The true stratigraphic position of each sample at Mauriceville and Central Mangaone Road sites was calculated using map information from previous studies. 


\subsubsection{Mangaoranga Stream section}

The Mangaoranga Stream section extends downstream from greywacke basement (Latitude: 40.67'S; Longitude: 175.73 'E) to the base of the Kaiparoro Formation (Latitude: 40.66'S; Longitude: 175.72'E), a traverse of approximately 2,900 m along the stream bed (Figure 2.2).

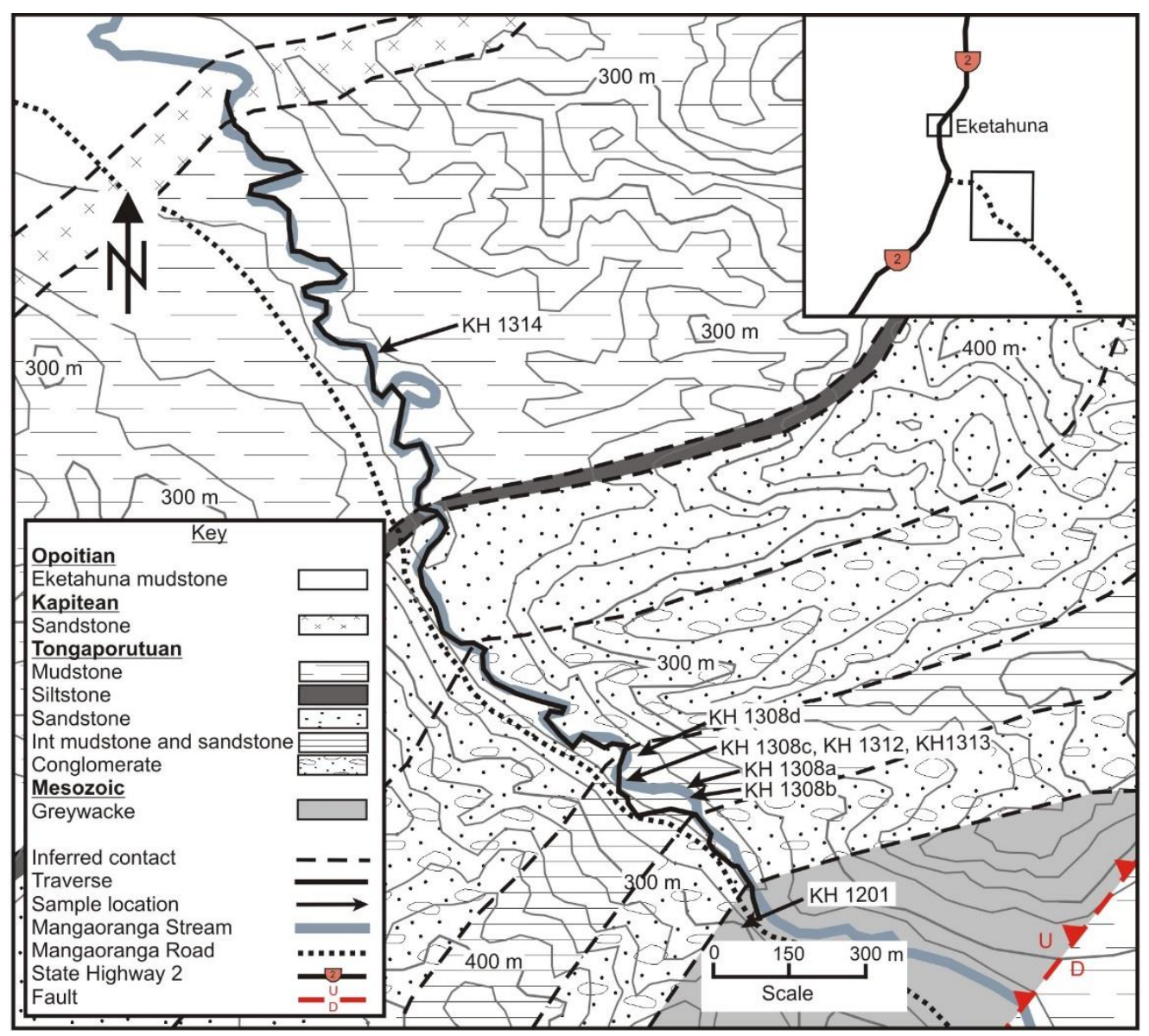

Figure 2.2: Map of the Mangaoranga Formation in Mangaoranga Stream, Eketahuna, with sample locations. Contour interval is $20 \mathrm{~m}$.

Measured section results

The present study has identified six units of the Mangaoranga Formation outcropping in Mangaoranga Stream: 1) conglomerate, 2) interbedded sandstone and mudstone, 3) conglomerate, 4) sandstone, 5) siltstone, and 6) mudstone. The results of the measured section are illustrated in Figure 2.3. 


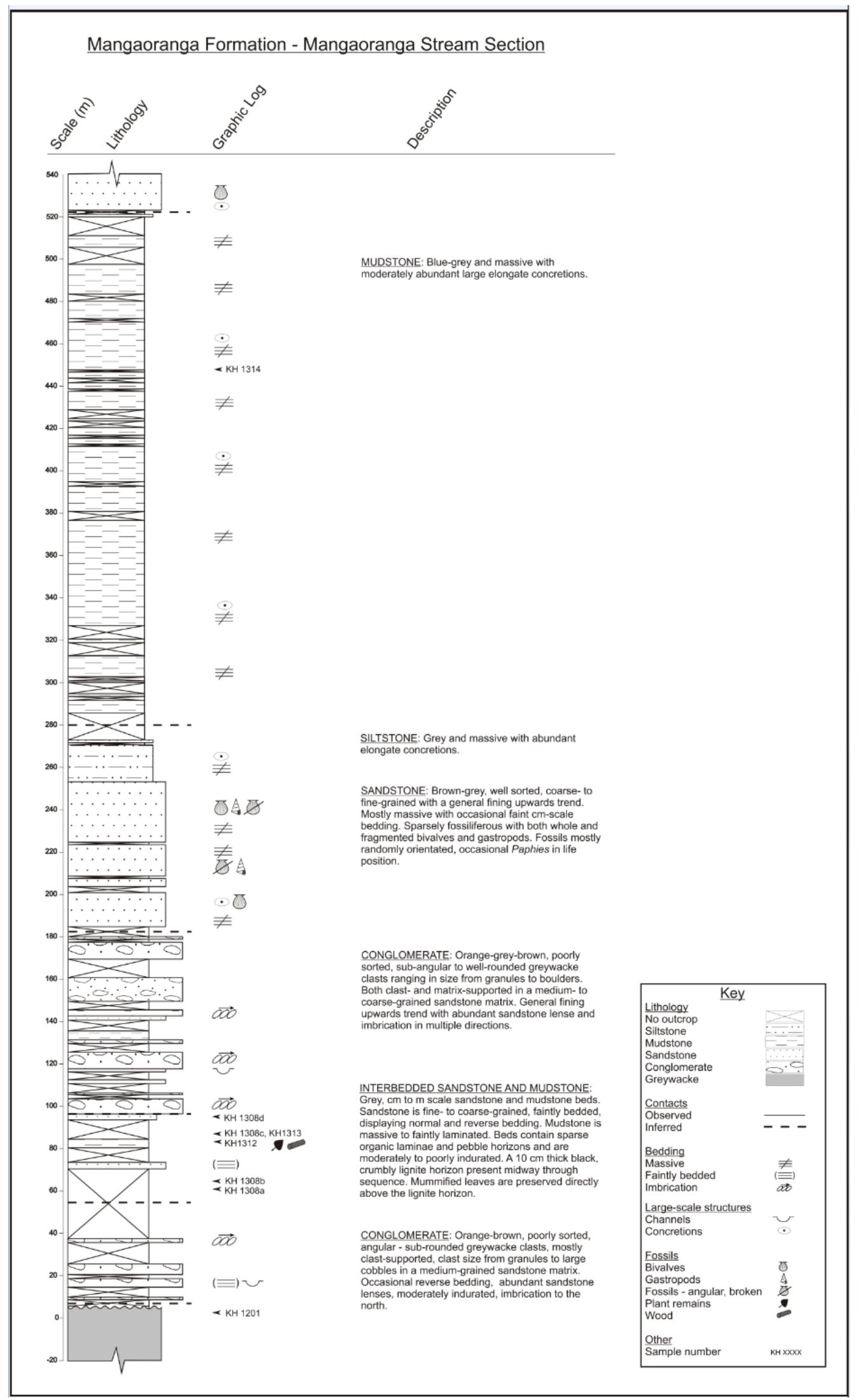

Figure 2.3: Measured section of the Mangaoranga Formation at Mangaoranga Stream, Eketahuna, with sample locations. 


\section{Conglomerate}

The basal unit of the Mangaoranga Formation is a $48 \mathrm{~m}$ thick, poorly sorted, moderately indurated conglomerate. The conglomerate is thought to uncomfortably overlie greywacke basement rocks; however, the lower contact is obscured by $39 \mathrm{~m}$ of vegetation along both banks of the stream.

i) The base of this unit is a $1 \mathrm{~m}$ thick, clast-supported, poorly sorted conglomerate (Figure 2.4). The conglomerate is composed of angular to sub-rounded (from visual roundness chart: Shepard \& Young, 1961) greywacke clasts ranging in size from granules to large cobbles (minimum $-1 \varnothing$; maximum $-7.6 \varnothing$; average $-6.7 \varnothing$ ) in a medium-grained sandstone matrix.

ii) Overlying this is a similar poorly sorted conglomerate with a smaller average clast size and increased rounding. This conglomerate is at least $24 \mathrm{~m}$ thick and has a sharp and wavy lower contact (Figure 2.4). It is mostly clast-supported and composed of sub-angular to sub-rounded greywacke clasts in a fine- to medium-grained sandstone matrix. The clasts range in size from granules to cobbles (minimum $-1 \varnothing$; maximum $-6.7 \varnothing)$ and fine-upwards with an average clast size of $-5.9 \varnothing$ near the base and $-4.5 \varnothing$ above this. The conglomerate is faintly bedded and contains occasional reverse bedding as well as abundant sandstone lenses. The lenses have gradational upper and lower contacts and consist of fine- to medium-grained sandstone with abundant wellrounded greywacke granules and pebbles (minimum -1 $\varnothing$; maximum $-2 \varnothing$; average $1.2 \varnothing)$. The thickness of each lens ranges from 10 to $30 \mathrm{~cm}$, with lengths up to $3.5 \mathrm{~m}$. Imbrication to the north is visible near the top of the conglomerate. 


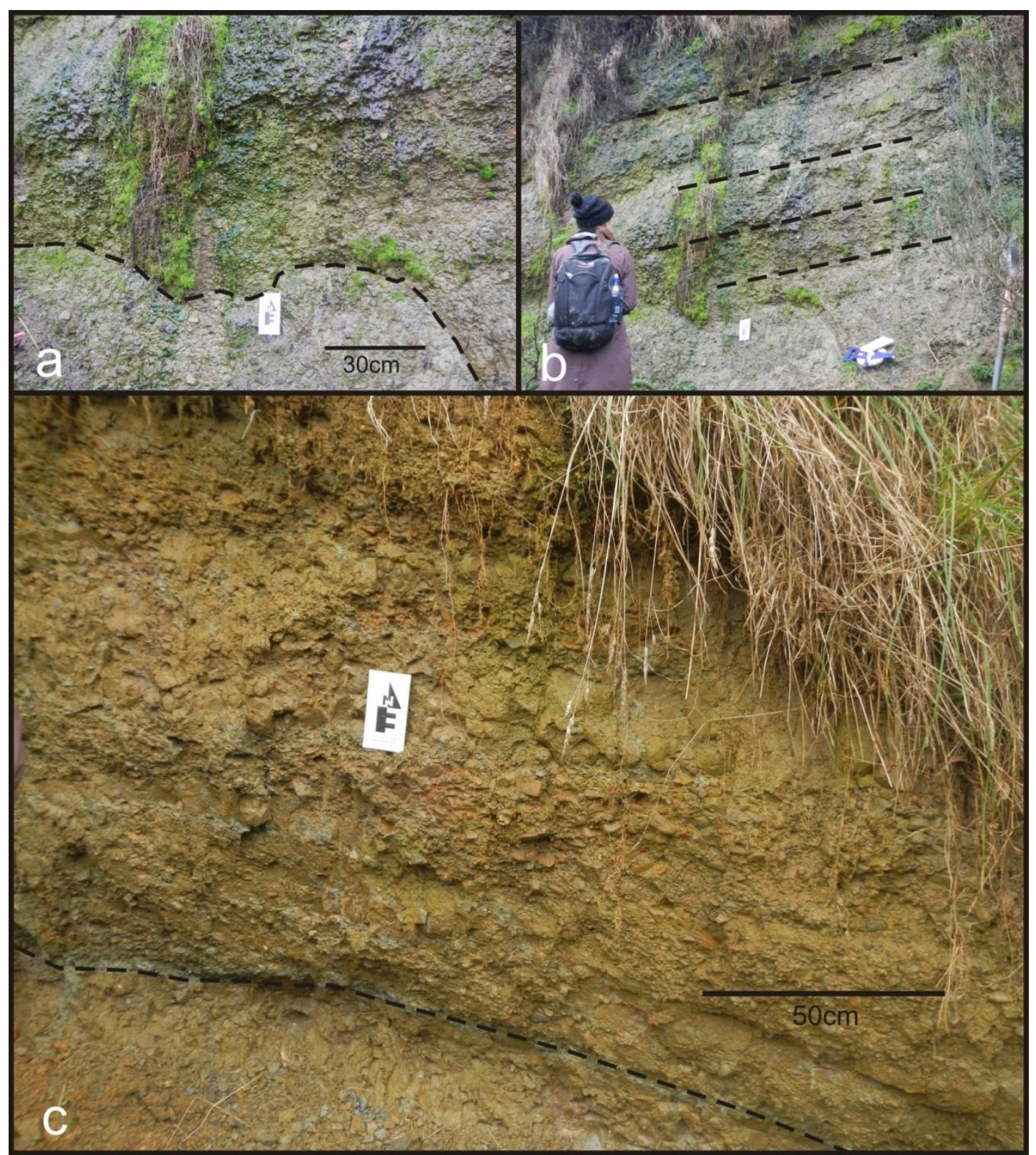

Figure 2.4: Features of the first conglomerate unit: a) contact between basal conglomerate and overlying conglomerate, $\mathrm{b}$ ) faint bedding and c) contact between a sandstone lens and overlying conglomerate. 


\section{Interbedded sandstone and mudstone}

Overlying the conglomerate is a $42 \mathrm{~m}$ thick sequence of moderately to poorly indurated sandstone and mudstone beds. The lower contact of this unit is obscured in outcrop by $139 \mathrm{~m}$ of landslide debris, equating to a vertical thickness of $24 \mathrm{~m}$.

i) The lower part of this unit is $30 \mathrm{~cm}$ thick and consists of mudstone and fine-grained sandstone laminations with sharp and planar contacts at the base of the sandstone (Figure 2.5). The sandstone grades upwards over $1-2 \mathrm{~cm}$ into mudstone, with occasional discontinuous organic laminae at the base of the mudstone.

ii) Directly overlying this laminated unit, with a sharp and planar basal contact, is a $14 \mathrm{~m}$ thick sequence of sandstone and mudstone interbeds. The interbeds are coloured grey, $1-2 \mathrm{~m}$ thick, and display both normal and reverse bedding.

a) The sandstone beds are fine- to coarse-grained, well sorted, faintly bedded on a $\mathrm{cm}$ scale, and contain abundant and discontinuous organic laminae. The coarse-grained sandstone beds also contain sparse conglomerate lenses. The lenses are between $15-20 \mathrm{~cm}$ long, up to $2 \mathrm{~cm}$ thick, are matrix-supported with coarse-grained sandstone, and consist of well-rounded greywacke granules and pebbles (-1 to $-2.5 \varnothing)$.

b) The mudstone beds are massive or finely laminated and occasionally contain sparse organic laminae.

iii) A $10 \mathrm{~cm}$ thick, brown-black, soft and discontinuous lignite horizon is present between one of the m-scale sandstone and mudstone beds (Figure 2.5). Both the upper and lower contacts of the lignite horizon with the overlying mudstone and underlying fine grained sandstone (respectfully) are gradational on a cm scale. The organic matter in the underlying sandstone significantly increases near the top of the bed while the organic matter directly above the lignite layer decreases upwards and contains moderately abundant whole fossil leaves. Where the lignite bed is missing, the fine-grained sandstone grades upwards into mudstone. 


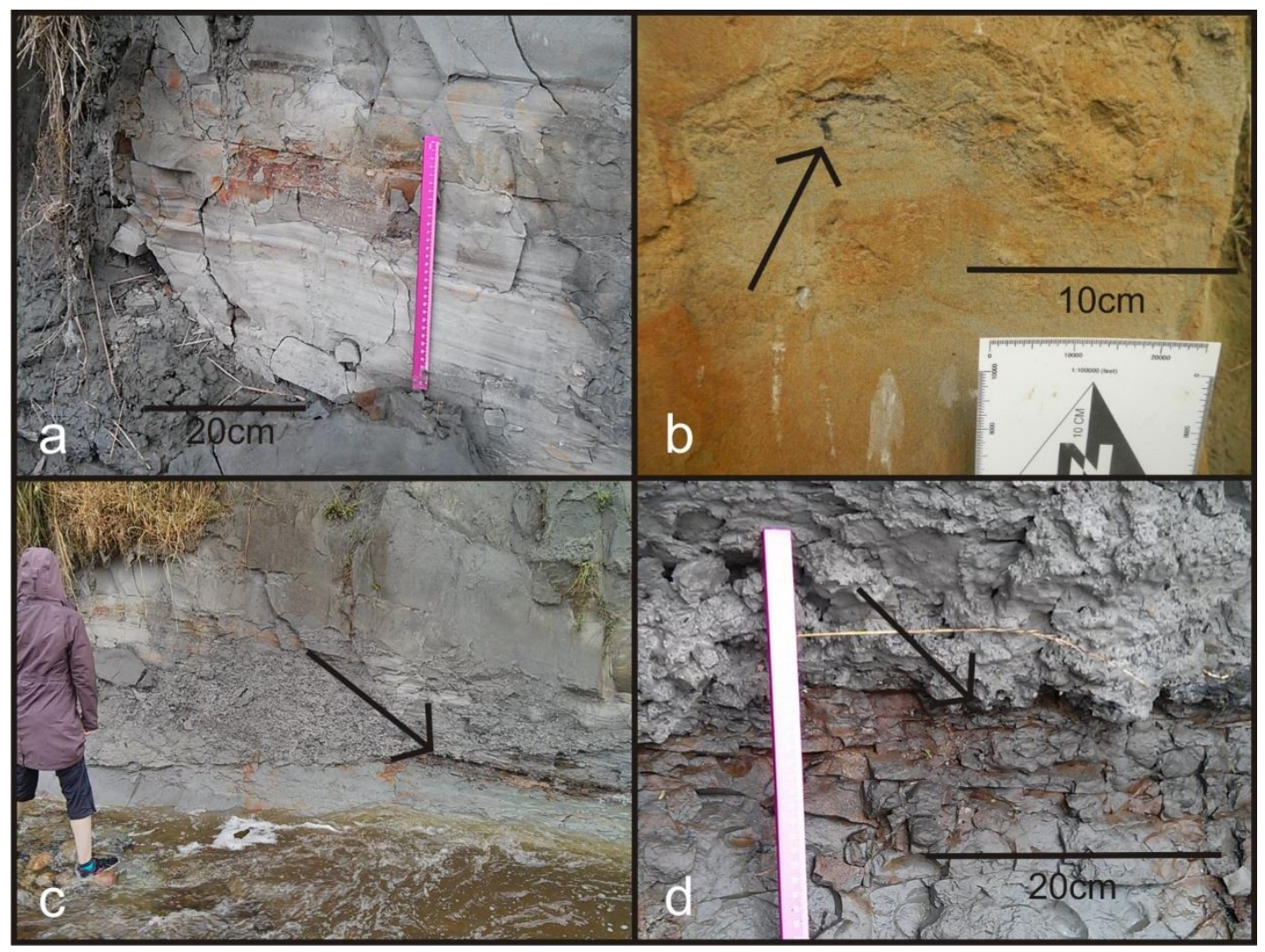

Figure 2.5: Features of the interbedded sandstone and mudstone unit: a) sandstone and mudstone laminations, b) basal sandstone with organic laminae, c) lignite horizon within mudstone bed and d) enlarged photograph (looking down) of lignite horizon in mudstone bed. 


\section{Conglomerate}

A second $85 \mathrm{~m}$ thick sequence of conglomerate outcrops above the interbedded sandstone and mudstone unit. The conglomerate has a fining-upwards with increased sorting trend and conformably overlies a fine-grained sandstone bed with a sharp and wavy lower contact.

i) The gross lithology is a mixed clast- and matrix-supported, poorly sorted conglomerate with a medium- to coarse-grained sandstone matrix. The conglomerate is composed of greywacke clasts which have an overall blade clast form. Near the base, the conglomerate contains well-rounded clasts ranging in size from granules to boulders (minimum $-1 \varnothing$; maximum $>-8 \varnothing$; average $-5.6 \varnothing$ ). Towards the middle of the sequence, the clasts become slightly more angular and have an average clast size of $-5.6 \varnothing$, with a maximum size of $-7.2 \varnothing$. Near the top, the conglomerate is moderately sorted with sub-angular to sub-rounded clasts with an average size of $5.3 \varnothing$. The conglomerate also contains abundant sandstone lenses, especially near the base and middle of the sequence (Figure 2.6). The lenses have both sharp and gradational boundaries and consist of fine- to coarse-grained sandstone with abundant rounded to well-rounded greywacke granules and pebbles (minimum -1 $\varnothing$; maximum $-4.9 \varnothing$; average $-3.4 \varnothing$ ). The average thickness of the lenses range from 3 $\mathrm{cm}-50 \mathrm{~cm}$, with lengths up to $0.5-2 \mathrm{~m}$. The sandstone lenses occasionally contain pebble lenses (Figure 2.6). At the base of the conglomerate, two $3-4 \mathrm{~m}$ thick, finegrained sandstone beds are exposed on the northern bank of the stream. The beds are massive and well sorted and have gradational lower contacts with the underlying conglomerate. The upper contacts are sharp and wavy and often contain channels. Similar channels are also present near the middle of the conglomerate sequence. Measurements of imbrication were taken throughout the sequence and indicate flow direction to the south and north-west near the base and east and southeast near the top. 


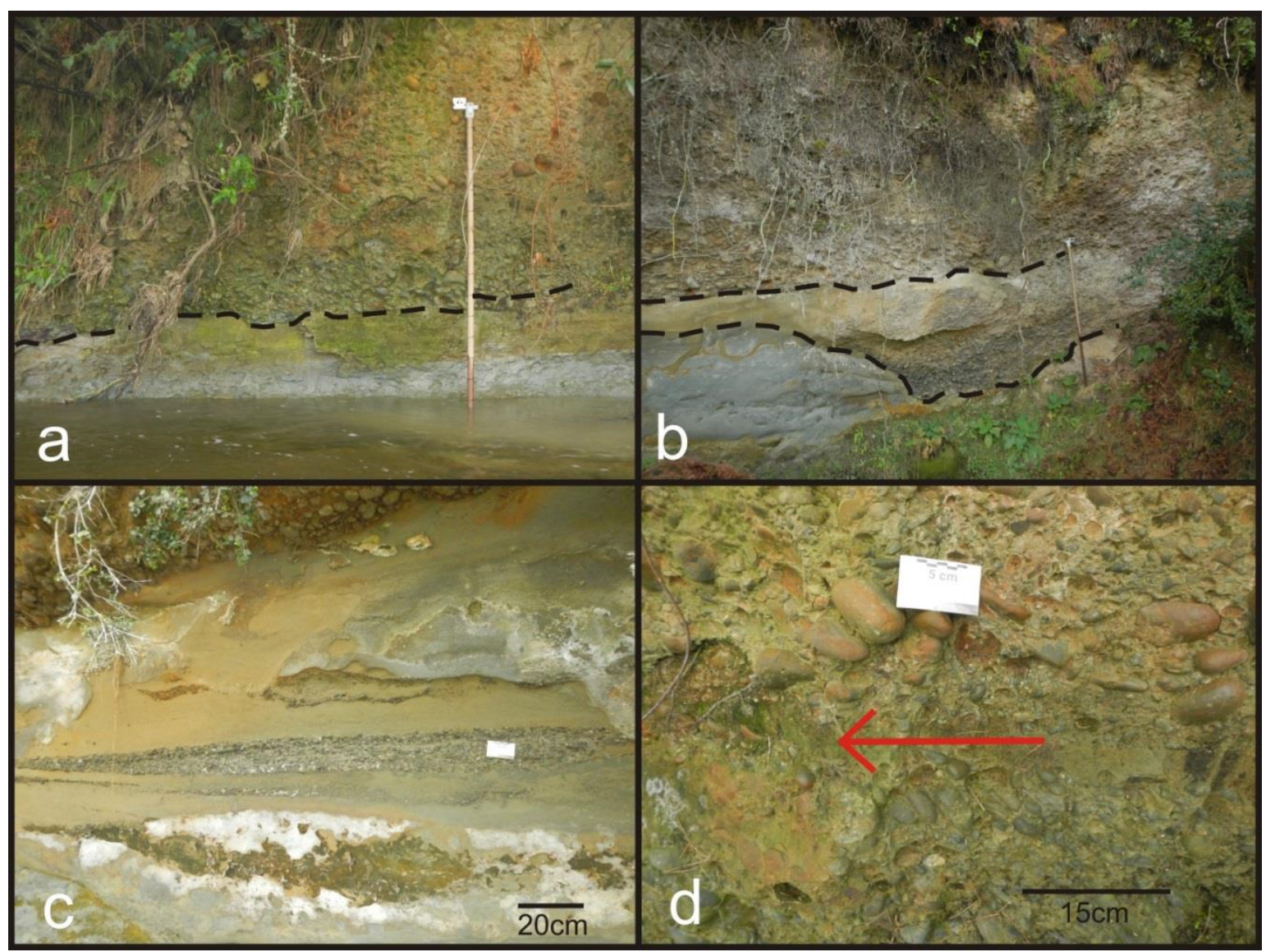

Figure 2.6: Features of the second conglomerate unit: a) contact between conglomerate and underlying sandstone, b) channelized contact, c) pebble lens within sandstone bed and d) imbrication. 


\section{Sandstone}

A $75 \mathrm{~m}$ thick sequence of fine-grained sandstone overlies the conglomerate in Mangaoranga Stream. The lower contact between the two members is obscured in outcrop by vegetation over a distance of $27 \mathrm{~m}$ along both banks of the stream.

i) The sandstone is generally massive, well-sorted, sparsely fossiliferous, and has a fining-upwards trend (Figure 2.7). The basal lithology consists of light brown, medium-grained sandstone. The sandstone gradually fines upwards into a sparsely fossiliferous, fine-grained sandstone with occasional faint $20-50 \mathrm{~cm}$ bedding. The fossils appear to be from gastropods and bivalves, are both whole and fragmented, randomly orientated, between $0.5-2 \mathrm{~cm}$ across and typically occur in clusters within a fine grained sandstone matrix (Figure 2.7). Some identified species include Paphies australis, Paphies sp., Crepidula radiate, Tucetona laticostata and possibly Dosina and Ruditapes. The sandstone then grades upwards into a very fine-grained fossiliferous sandstone. The fossils within this section are similar to those described above; however Paphies sp. was found in life position. The sandstone finally grades upwards into a massive, grey, mudstone. Near the top of this member, large spherical concretions $2 \mathrm{~m}$ thick and up to $5 \mathrm{~m}$ long are abundant. 


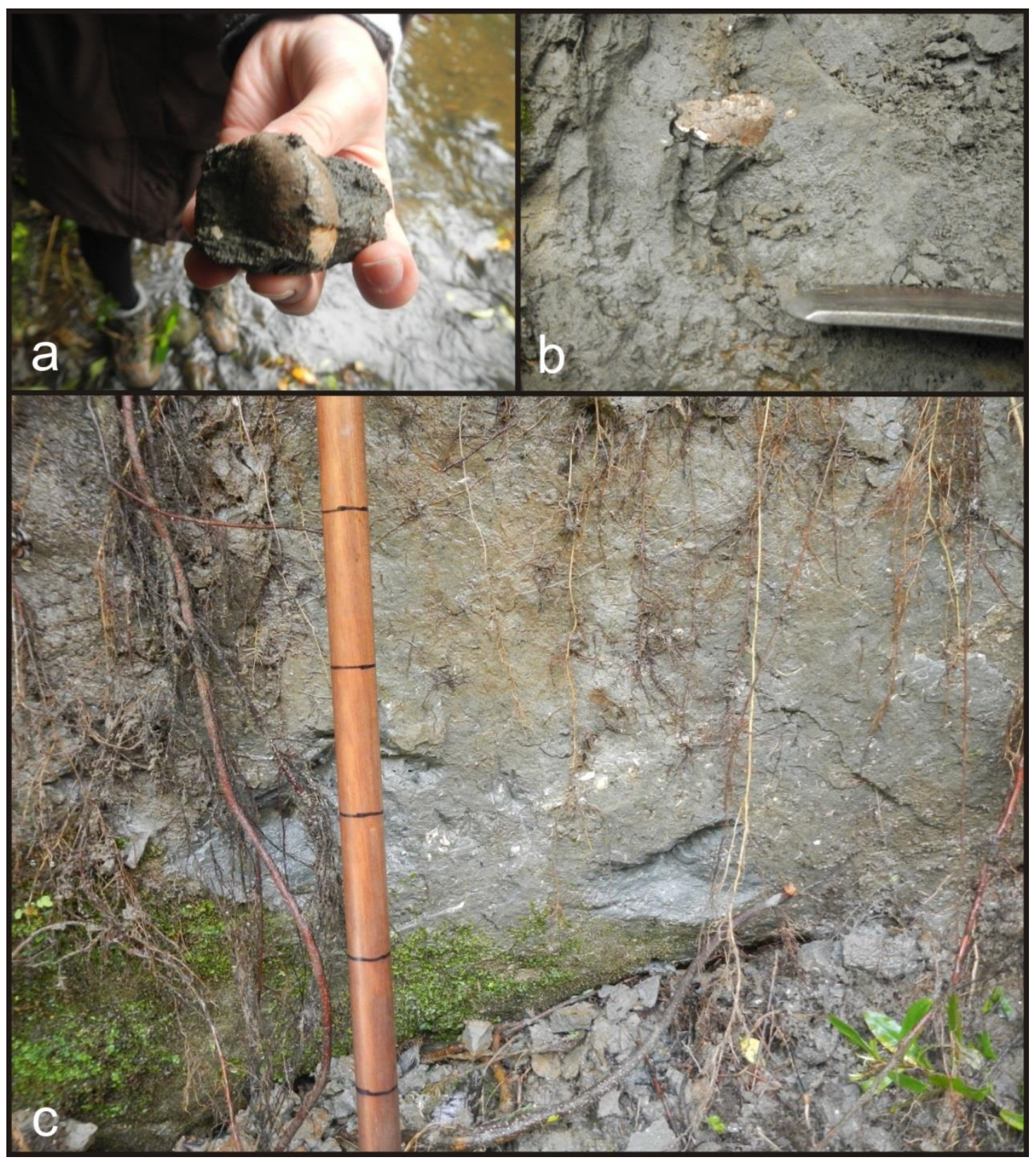

Figure 2.7: Features of the sandstone unit: a) Crepidula radiata, b) unidentified mollusc and c) shell hash. 


\section{Siltstone}

Overlying the sandstone unit with a sharp and wavy lower contact is a $16 \mathrm{~m}$ thick sequence of siltstone (Figure 2.8). The siltstone is light grey in colour, massive, and contains abundant elongate concretions, on average $25 \mathrm{~cm}$ thick, with lengths up to $40 \mathrm{~cm}$.

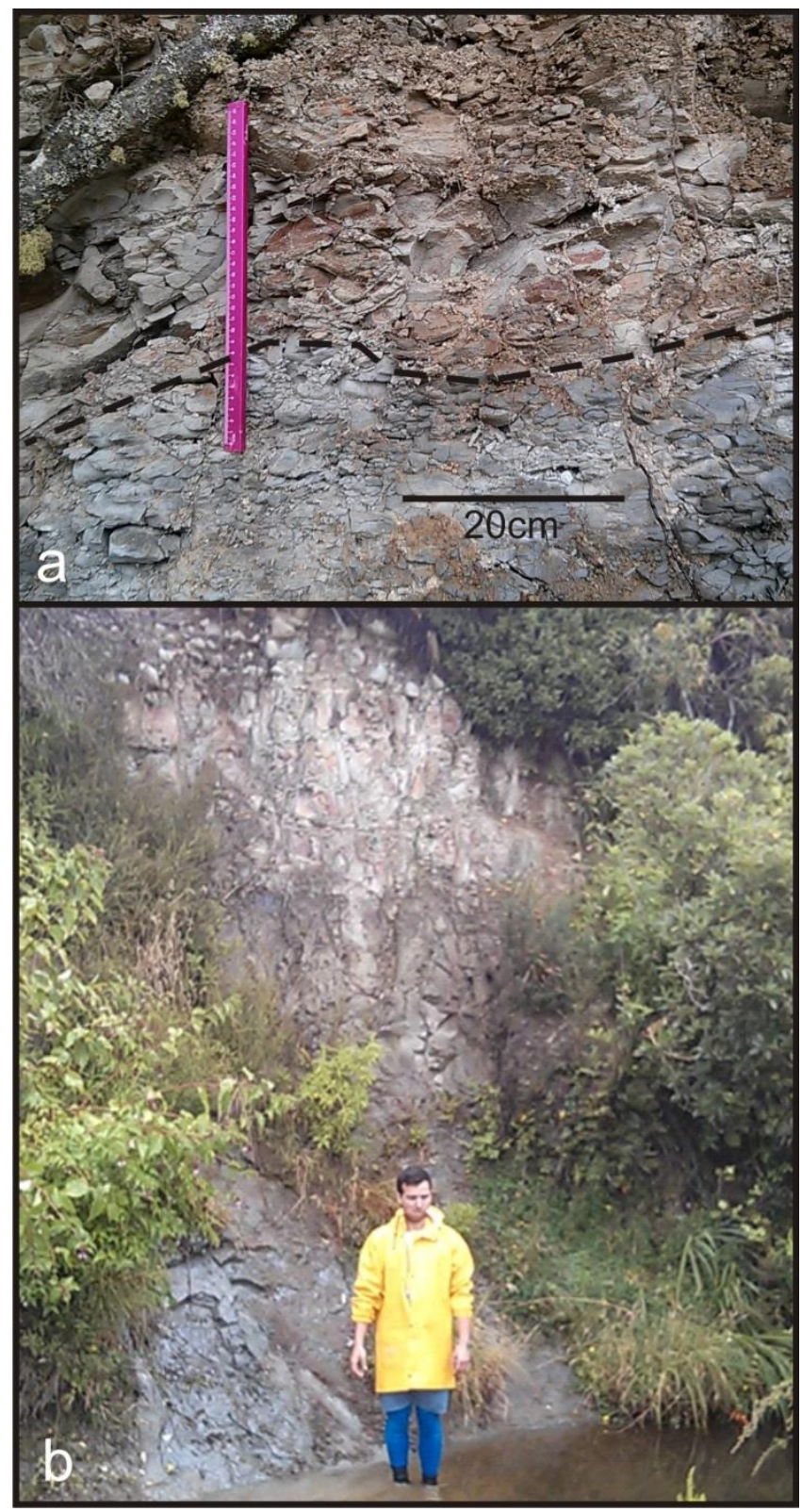

Figure 2.8: Features of the siltstone unit: a) contact between siltstone and underlying mudstone and $\mathrm{b}$ ) wider photograph of the siltstone above mudstone. 


\section{Mudstones}

The thickest unit of the Mangaoranga Formation is a $242 \mathrm{~m}$ thick sequence of mudstone. The lower contact between this member and underlying siltstone is obscured in outcrop by $29 \mathrm{~m}$ of vegetation along both banks of the stream. The mudstone is blue grey in colour, massive, and contains sparse, spherical concretions (Figure 2.9). The concretions are on average $7 \mathrm{~cm}$ thick and $20-30 \mathrm{~cm}$ long. A large, $50 \mathrm{~cm}$ thick concretionary layer outcrops $50 \mathrm{~m}$ from the base of the unit. $3 \mathrm{~m}$ below the top of this unit, the mudstone gradually becomes sandier.

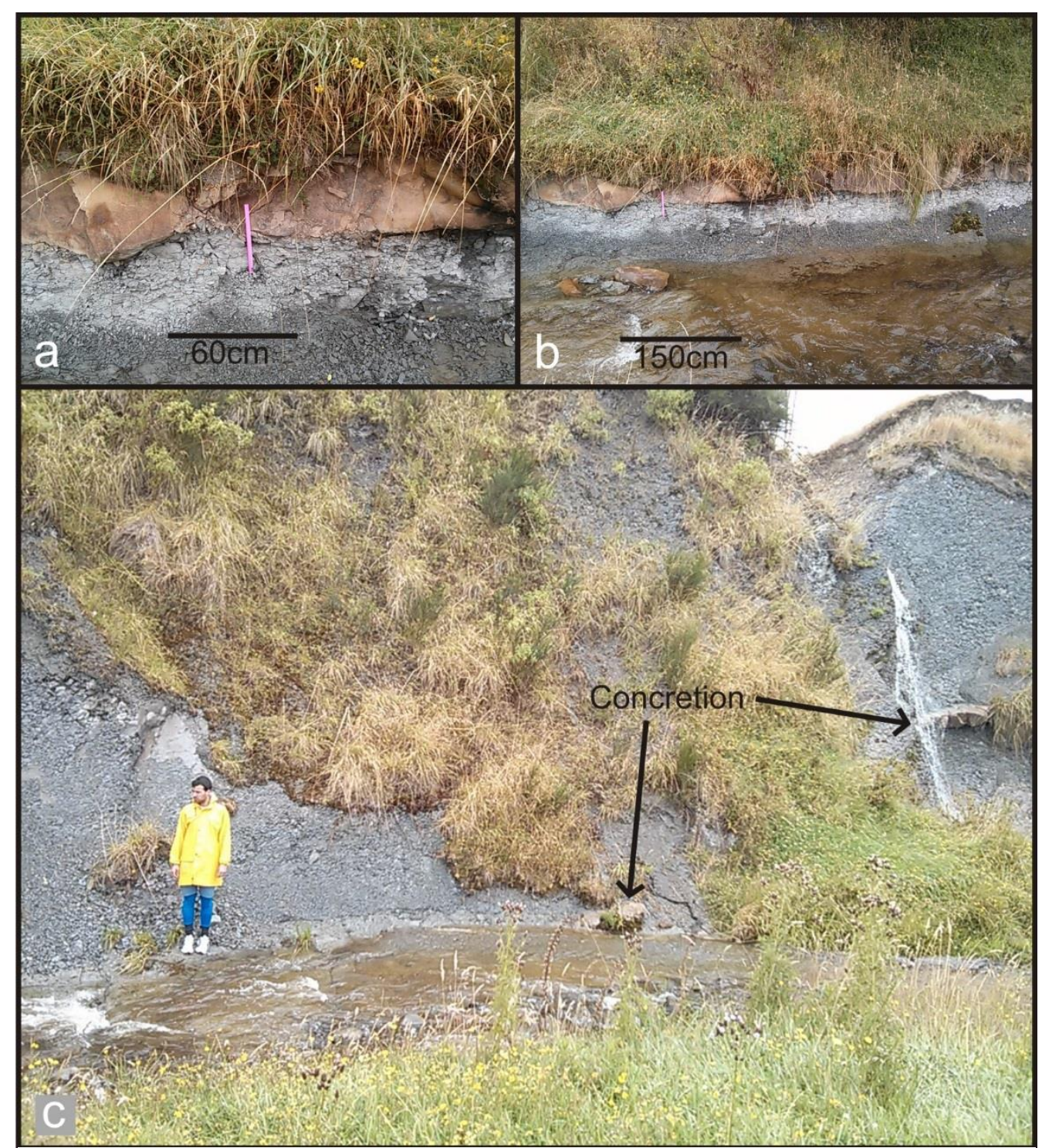

Figure 2.9: Features of the mudstone unit: a) concretionary layer, b) wider photograph of the concretionary layer showing its scale of continuity and c) general exposure of the mudstone with two visible concretions. 


\subsubsection{Mauriceville section}

The Mauriceville section extends from greywacke basement (Latitude: 40.76'S; Longitude: 175.71 'E) to the top of the Mangaoranga Formation (Latitude: 40.76'S; Longitude: 175.70' E) (Figure 2.10). Exposure is now poor and so descriptions of the formation here follow those of Orbell (1961).

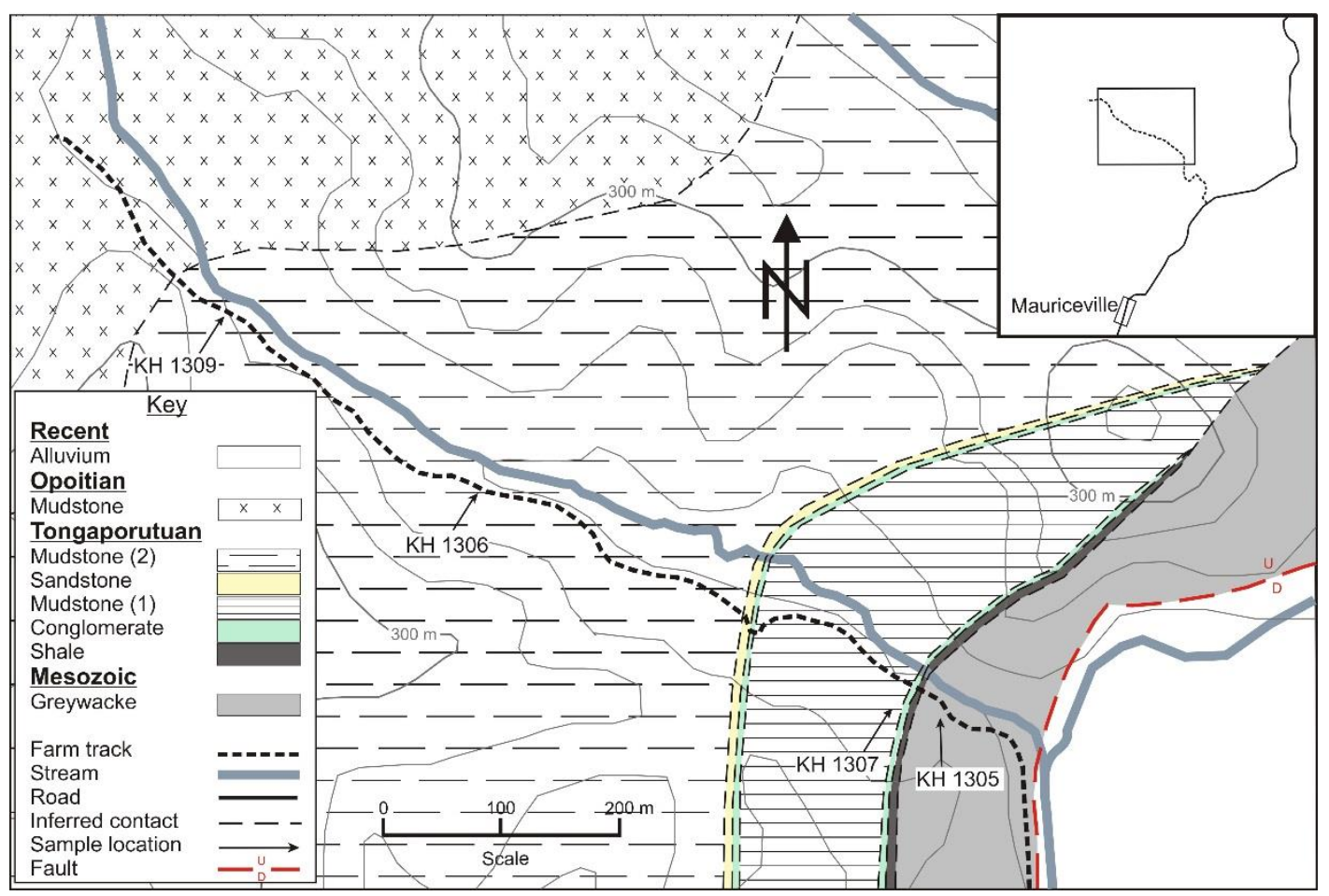

Figure 2.10: Map of the Mangaoranga Formation at the Mauriceville section, Mauriceville, with sample locations. Stratigraphic units are those of Orbell (1961), who did not define lithostratigraphic units. Mudstone 1 is inferred to be terrestrial while mudstone 2 is inferred to be marine. The strata of Tongaporutuan age have since been placed into the Mangaoranga Formation. Contour interval is $20 \mathrm{~m}$.

Six units of the Mangaoranga Formation are present at this locality, with a total thickness of $236 \mathrm{~m}$ (Figure 2.11). These units are: 1) greywacke conglomerate (3 m thick) unconformably overlying greywacke basement, 2) carbonaceous shale (60 cm thick), 3) greenish-blue-grey non-marine mudstone (61 m thick: mudstone 1), 4) greywacke conglomerate $(1.5 \mathrm{~m}$ thick) 5$)$ cemented fossiliferous sandstone $(3 \mathrm{~m}$ thick) and 6) greenish-blue-grey marine mudstone (167 m thick: mudstone 2). 


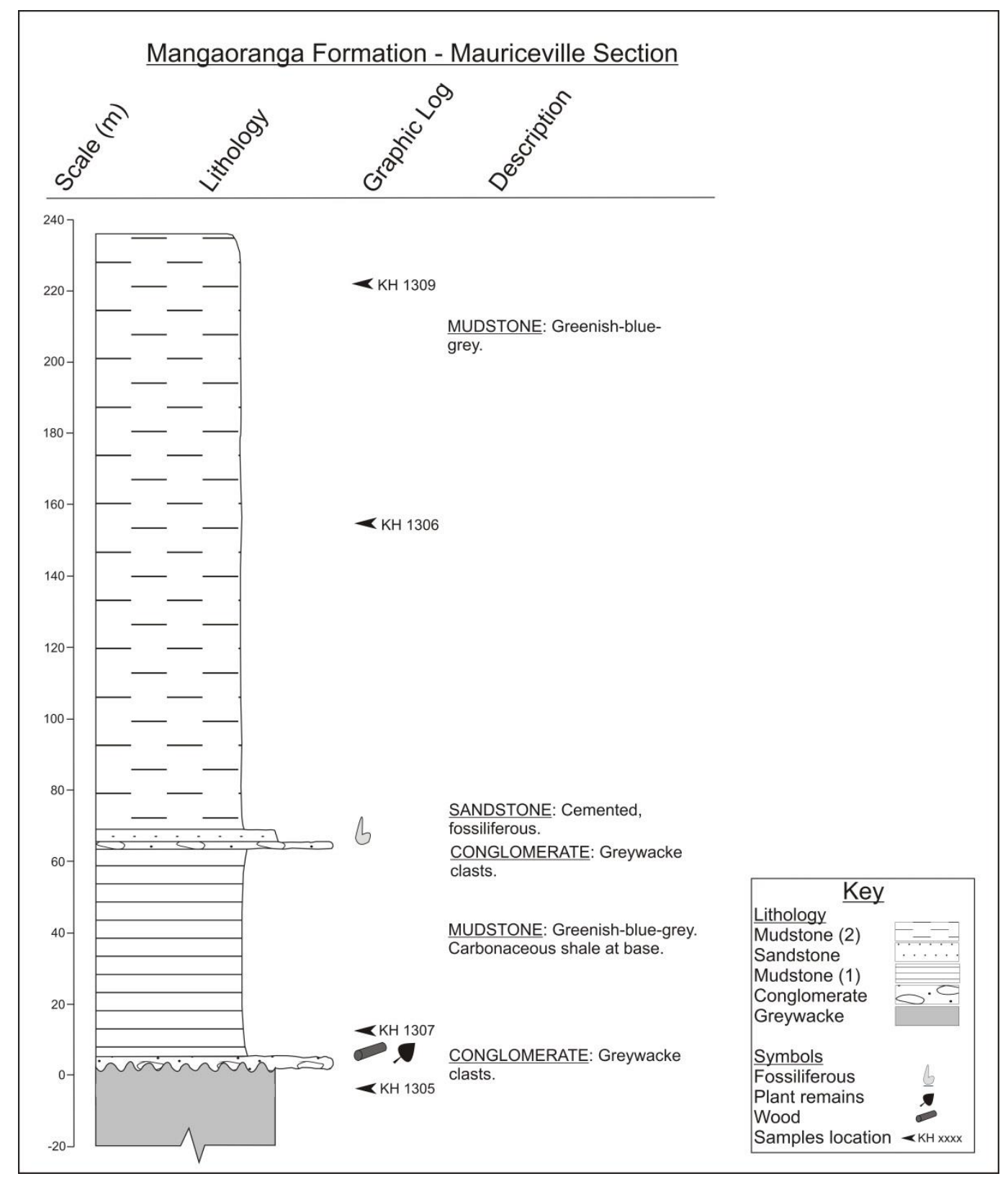

Figure 2.11: Stratigraphic column of the Mangaoranga Formation at the Mauriceville section, with sample locations. Modified after Orbell (1961). 


\subsubsection{Central Mangaone Road section}

The Central Mangaone Road section extends from greywacke basement (Latitude: 40.46'S; Longitude: 175.76 'E) to the top of the Mangaoranga Formation (Latitude: 40.62'S; Longitude: 175.76'E), along Central Mangaone Road (Figure 2.12).

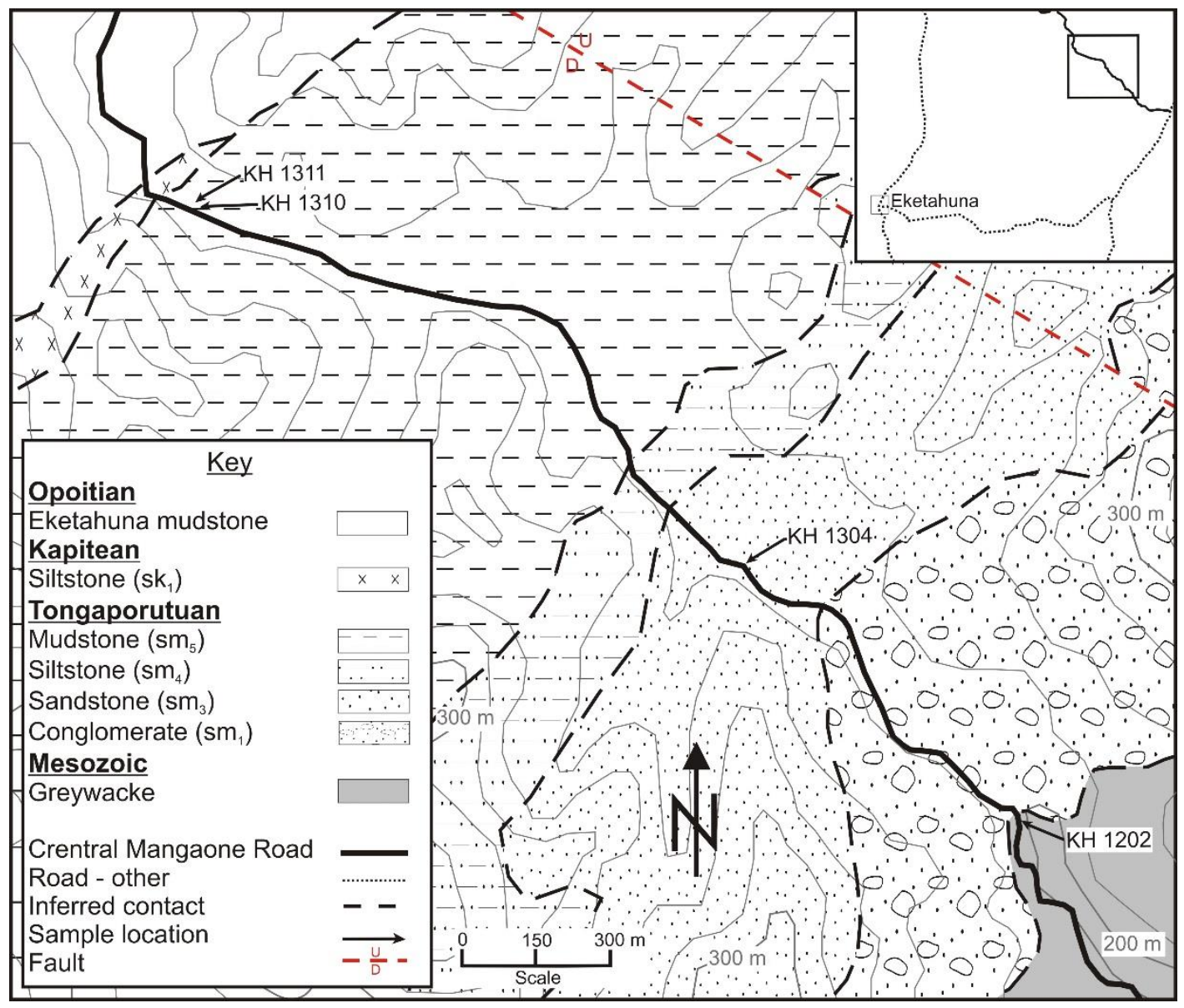

Figure 2.12: Map of the Mangaoranga Formation at the Central Mangaone Road section, Eketahuna, with sample locations. The Mangaoranga Formation encompasses all Tongaporutuan strata. The Kaiparoro Formation is represented by the Kapitean strata and the Eketahuna Group by Opoitian strata. Modified after Neef (1984). Contour interval is $20 \mathrm{~m}$.

Neef (1984) recognised 4 members of the Mangaoranga Formation at this locality, with a total thickness of $244 \mathrm{~m}$ (Figure 2.13). These members are: 1) $\mathrm{sm}_{1}$ conglomerate, 2) $\mathrm{sm}_{3}$ sandstone, 3) $\mathrm{sm}_{4}$ siltstone and 4) $\mathrm{sm}_{5}$ mudstone.

Exposure is now poor and Figure 2.13 and the following descriptions are after Neef (1984): 


\section{Conglomerate}

The basal member of the Mangaoranga Formation to crop out unconformably above greywacke basement at this locality is a $37 \mathrm{~m}$ thick sequence of $\mathrm{sm}_{1}$ conglomerate. The conglomerate is well sorted, closely packed, and contains well-rounded greywacke cobbles and pebbles, with boulders up to $45 \mathrm{~cm}$ across.

\section{Sandstone}

Overlying the $\mathrm{sm}_{1}$ conglomerate is a $49 \mathrm{~m}$ thick sequence of $\mathrm{sm}_{3}$ sandstone. The contact between the two members is not described by Neef (1984) at this locality; however south of this location, the contact is described as gradational. The sandstone member is fine-grained, massive and fossiliferous. Near the base of the member, rare pebble horizons are present.

\section{Siltstone}

Abruptly overlying the $\mathrm{sm}_{3}$ sandstone member is a $24 \mathrm{~m}$ thick sequence of $\mathrm{sm}_{4}$ siltstone.

\section{Mudstone}

Overlying the siltstone member, with the nature of the contact unknown, is $244 \mathrm{~m}$ of $\mathrm{sm}_{5}$ mudstone. The mudstone member contains rare silty horizons and elongate calcareous concretions. 


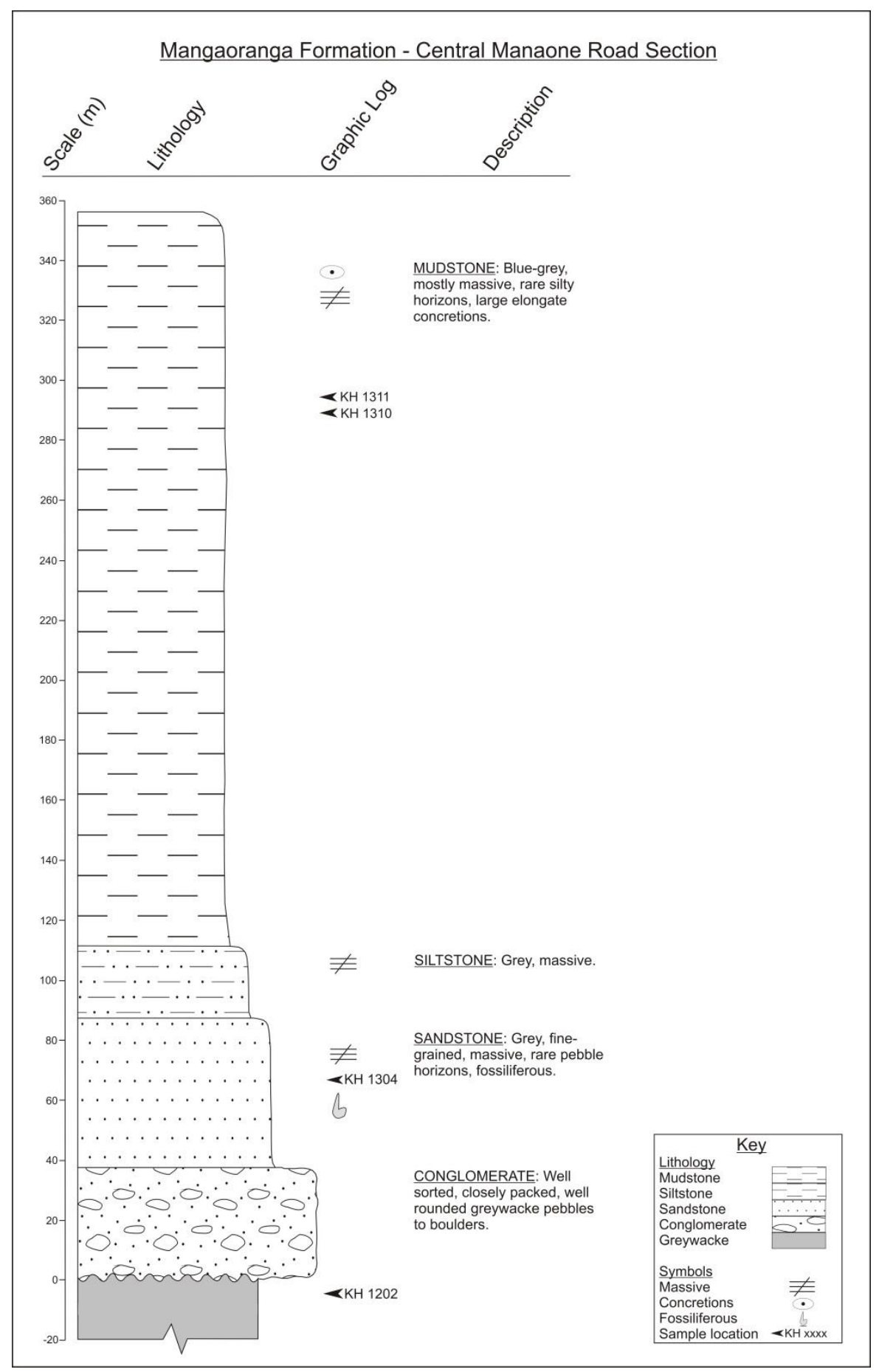

Figure 2.13: Stratigraphic column of the Mangaoranga Formation at the Central Mangaone Road section, Eketahuna, with sample locations. After Neef (1984). 


\subsubsection{Mt Bruce section}

The Mt Bruce section, mapped and described by Wells (1985) extends from greywacke basement to the top of the Mangaoranga Formation. The lower members of the formation $\left(\mathrm{sm}_{0}, \mathrm{sm}_{2}\right.$ and $\left.\mathrm{sm}_{3}\right)$ are exposed along the banks of Ruamahanga River, while the upper members ( $\mathrm{sm}_{4}$ and $\mathrm{sm}_{5}$ ) are exposed along the roadside of State Highway 2, about $1 \mathrm{~km}$ north of the lower section (Figure 2.14).

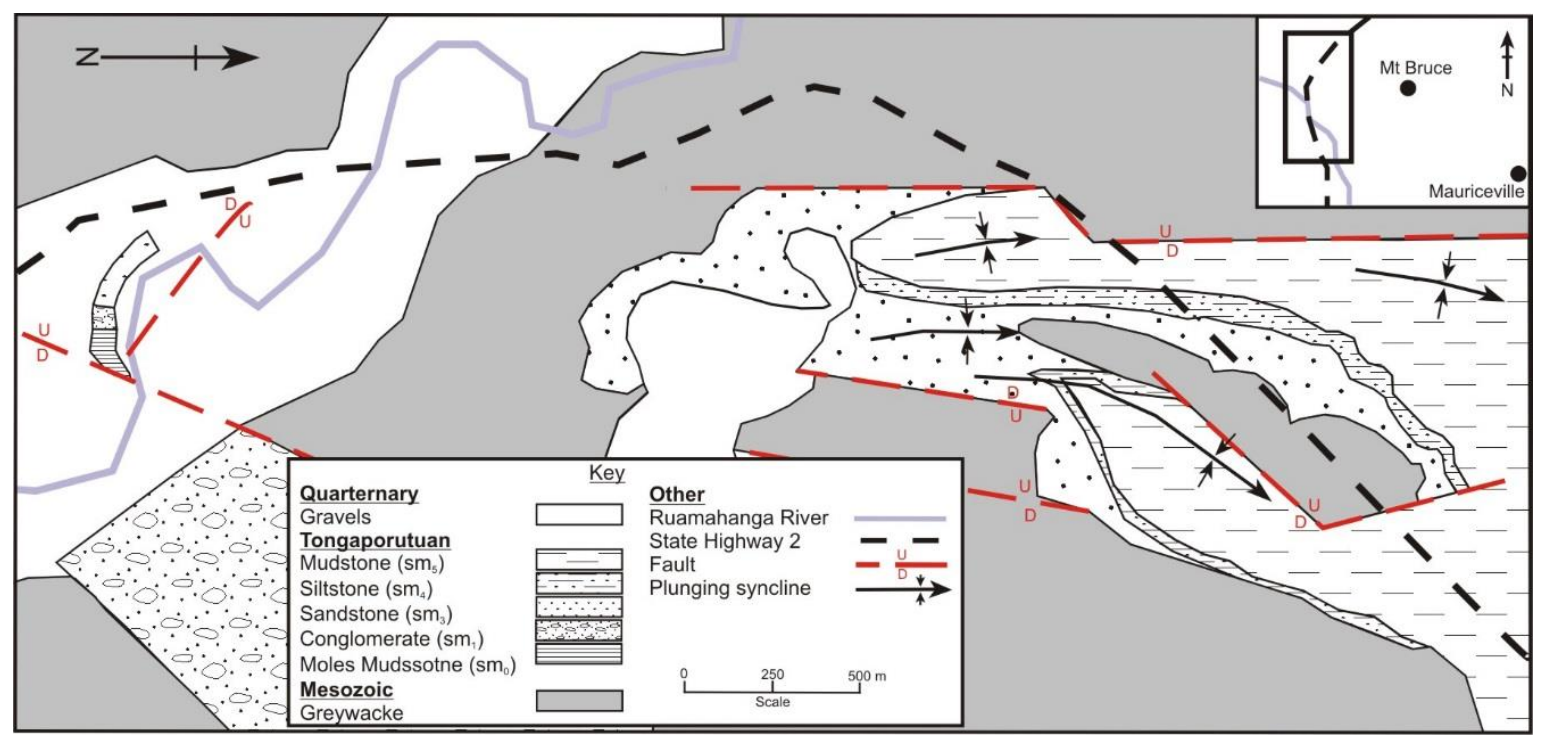

Figure 2.14: Map of the Mangaoranga Formation at the Mt Bruce section, Mt Bruce. The Mangaoranga Formation encompasses all Tongaporutuan strata. Modified after Wells (1985).

Wells (1985) identified five members of the Mangaoranga Formation to crop out in the Mt Bruce area, with a maximum thickness of $530 \mathrm{~m}$ (Figure 2.15). Four of the five members were correlated to those described by Neef (1984) in Mangaoranga Stream. One new basal member was described by Wells (1985). The members are: 1) $\mathrm{sm}_{0}$ Moles Mudstone, 2) $\mathrm{sm}_{1}$ conglomerate, 3) $\mathrm{sm}_{3}$ sandstone, 4) $\mathrm{sm}_{4}$ siltstone and 5) $\mathrm{sm}_{5}$ mudstone.

The following descriptions are after Wells (1985):

\section{Moles Mudstone, smo}

The basal member of the Mangaoranga Formation at Mt Bruce is Moles Mudstone. The member is around 23 thick and contains four units. The basal unit is $2 \mathrm{~m}$ thick and consists of massive, blue-grey mudstone, which is overlain by unit two, a $0.2 \mathrm{~m}$ 
thick lignite horizon. Overlying the lignite horizon is unit three, a poorly sorted conglomerate. The conglomerate is $0.3 \mathrm{~m}$ thick and contains well-rounded greywacke pebbles in a sandstone matrix. The last unit of Moles Mudstone is a $22 \mathrm{~m}$ thick sequence of massive blue-green mudstone. The mudstone contains occasional plant fragments, concretions, foraminifera and molluscs.

\section{Conglomerate, $\mathrm{sm}_{1}$}

Overlying Moles mudstone with a sharp, erosional contact is between 60 and $120 \mathrm{~m}$ of conglomerate. The conglomerate is poorly sorted and contains blade-shaped subangular to well-rounded greywacke pebbles and boulders in a sandstone matrix. Bedding is defined by sandstone and concretionary horizons. The conglomerate grades upwards into a pebbly sandstone. Boulders near the top of the member contain abundant molluscs, such as Glycymeris (Grandaxinea) laticostata and Sectipecten sp. Imbrication measurements suggest paleocurrent flow to the north to north east.

\section{Sandstone, $\mathrm{sm}_{3}$}

Overlying the $\mathrm{sm}_{1}$ conglomerate with a gradational contact is $120 \mathrm{~m}$ of sandstone. Near the base, the sandstone is grey-brown, fine grained, poorly sorted and contains common well-rounded greywacke pebble lenses. The sandstone fines-upwards into well sorted very-fine sand. The sandstone is sporadically fossiliferous, containing fragments of molluscs.

\section{Siltstone, $\mathrm{sm}_{4}$}

$30 \mathrm{~m}$ of $\mathrm{sm}_{4}$ siltstone conformably overlies the $\mathrm{sm}_{3}$ sandstone at Mt Bruce. The siltstone is pale-green, massive and contains concretions. The coral Oculina virgosa was found within the concretions.

\section{Mudstone, $\operatorname{sm}_{5}$}

Overlying the $\mathrm{sm}_{4}$ siltstone is $240 \mathrm{~m}$ of massive blue-grey mudstone. 


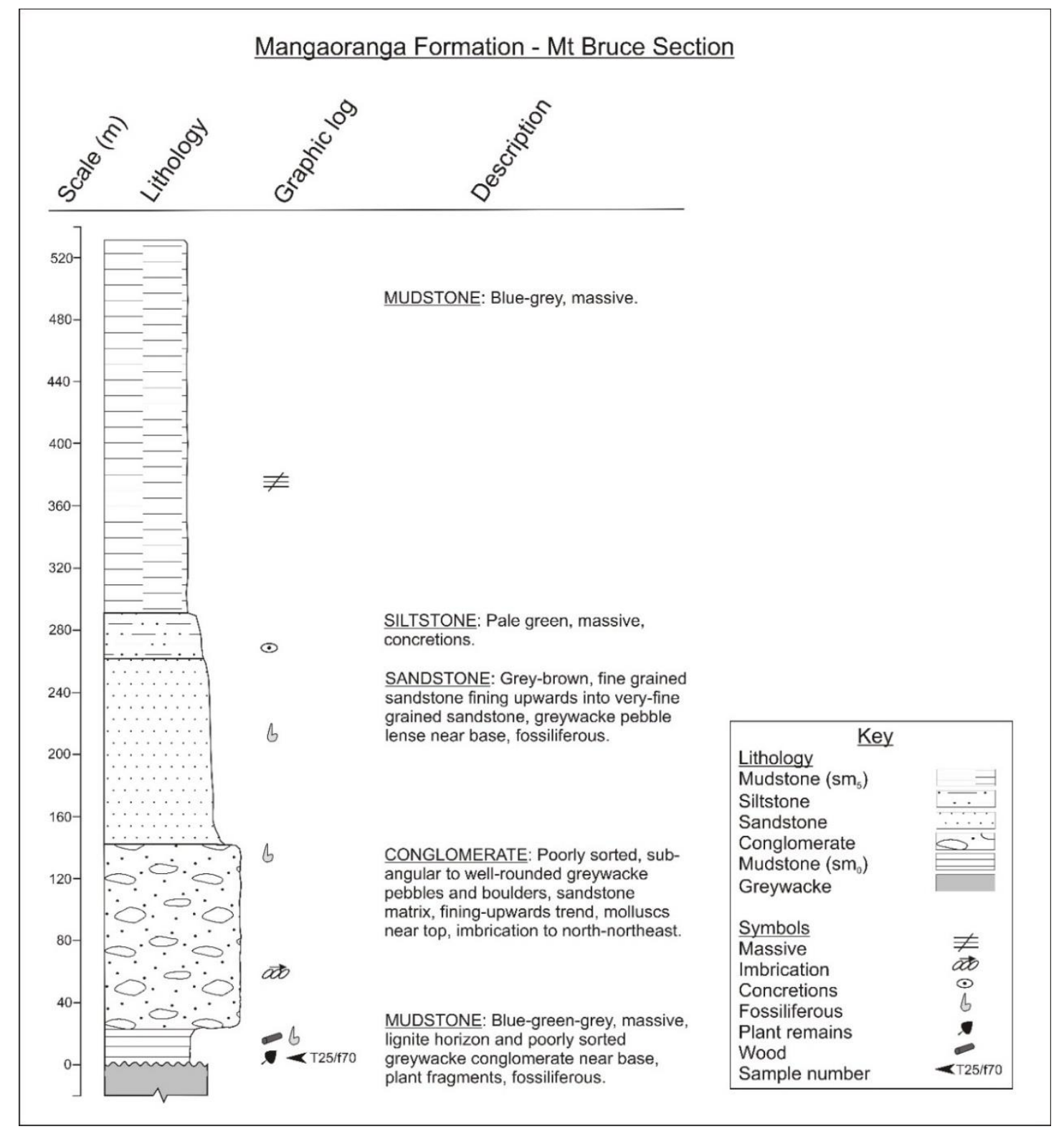

Figure 2.15: Stratigraphic column of the Mangaoranga Formation at the Mt Bruce section, Mt Bruce, with sample location. After Wells (1985). 


\subsubsection{Stratigraphic age}

Attempts to constrain the age of the Mangaoranga Formation were made in the present study by examining the fossil pollen and spores age ranges, as well as examining an apparent volcanic ash horizon near the top of the formation (previously described by Neef (1984)). The results of the pollen and spore analysis do not help to constrain the age of the formation, as the taxa identified were found to cover a large time span. All ages of the fossil pollen and spores were found to overlap during the Neogene $(23-2.6 \mathrm{Ma})$, with the abundance of cool temperate taxa and presence of Ligulifloridites sp. further refining deposition of the formation to the Late Neogene (11.6 - 2.6 Ma). The results of the 'volcanic ash' analysis also do not aid in constraining the age of the formation, as it was found that there was no volcanic glass present within the horizon. Thus, the layer could not be dated.

Attempts to refine the age of the formation in this study were unsuccessful, thus the age of Tongaporutuan (11 - $7 \mathrm{Ma})$, as suggested in previous studies, remains the depositional age of the Mangaoranga Formation.

\subsubsection{Stratigraphic correlations}

No definitive age of any one horizon of the Mangaoranga Formation has been identified in previous studies. Thus, dated marker horizons cannot be used to correlate members of the formation at different localities. Instead, the only available information that can be used to correlate members are lithological descriptions and the stratigraphic position of members below the upper Mangaoranga Formation marine transgressional sequence (members $\mathrm{sm}_{3}, \mathrm{sm}_{4}$ and $\mathrm{sm}_{5}$ ). Based on these, strata of the Mangaoranga Formation at the Mangaoranga Stream and Mauriceville sites have here been correlated to members described by Neef (1984) in Mangaoranga Stream (Figure 1.3). Strata at the Central Mangaone Road site were mapped by Neef (1984) and so are already correlated to the strata in Mangaoranga Stream. The accuracy of these correlations is limited by the lack of age constraints, a common issue with non-marine strata. 
Lithological descriptions have previously been used in studies of the Mangaoranga Formation in the Mt Bruce (Wells, 1985) and Carrington areas (Wells, 1989a) to correlate members of the formation there to members described by Neef (1984) in Mangaoranga Stream. Figure 2.16 illustrates the proposed correlation of members of the Mangaoranga Formation.

\section{Mangaoranga Stream section}

The present study identified six units of the Mangaoranga Formation to crop out in Mangaoranga Stream. Five of these units have been correlated to members described by Neef (1984) at the same site. The correlations are as follows:

Present study

Mudstone

Siltstone

Sandstone

Conglomerate

Interbedded sandstone and mudstone

Conglomerate correlated to

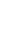


similar stratigraphic position to the $\mathrm{sm}_{2}$ marl described by Neef (1984), but no marl was observed during the present investigation. As a result, a new code has been proposed to identify the interbedded sandstone and mudstone unit $-\mathrm{sm}_{6}$ (interbedded sandstone and mudstone).

\section{$\underline{\text { Mauriceville section }}$}

Four of the five units described by Orbell (1961) at the Mauriceville section have been correlated to members described by Neef (1984) in Mangaoranga Stream. The correlations are as follows:

Orbell (1961)

Mudstone (marine)

Conglomerate

Mudstone (non-marine, including basal shale)

correlated to $\underline{\text { Neef (1984) }}$

sm5 Mudstone

$\mathrm{sm}_{4}$ Siltstone

$\mathrm{sm}_{3}$ Sandstone

$\mathrm{sm}_{1}$ Conglomerate

$\mathrm{sm}_{2}$ Marl

$\mathrm{sm}_{1}$ Conglomerate

Breccia

The basal breccia unit, $\mathrm{sm}_{2}$ marl, and $\mathrm{sm}_{4}$ siltstone described by Neef (1984) in Mangaoranga Stream were not recognised by Orbell (1961) at the Mauriceville section. However, at this section, non-marine mudstone overlying a thin carbonaceous horizon was recognised above basal conglomerate. This non-marine mudstone could be correlable to one of two mudstone members: sm6 $_{6}$, in Mangaoranga Stream, Eketahuna, or $\mathrm{sm}_{0}$ (Moles Mudstone), in Ruamahanga River, Mt Bruce (Wells, 1985). The $\mathrm{sm}_{6}$ member is located at a similar stratigraphic position to the Mauriceville mudstone, between $\mathrm{sm}_{1}$ conglomerates, and has a similar lithology. The Moles Mudstone member is also located at a similar stratigraphic position to the Mauriceville mudstone, however Moles Mudstone contains a 
macrofaunal assemblage indicating deposition in an estuarine environment. There is no evidence within the non-marine mudstone in Mauriceville that suggests deposition in an estuarine environment. Thus, it is here inferred that the non-marine mudstone member described by Orbell (1961) in Mauriceville is correlable to sm6 (interbedded sandstone and mudstone), in Mangaoranga Stream. 


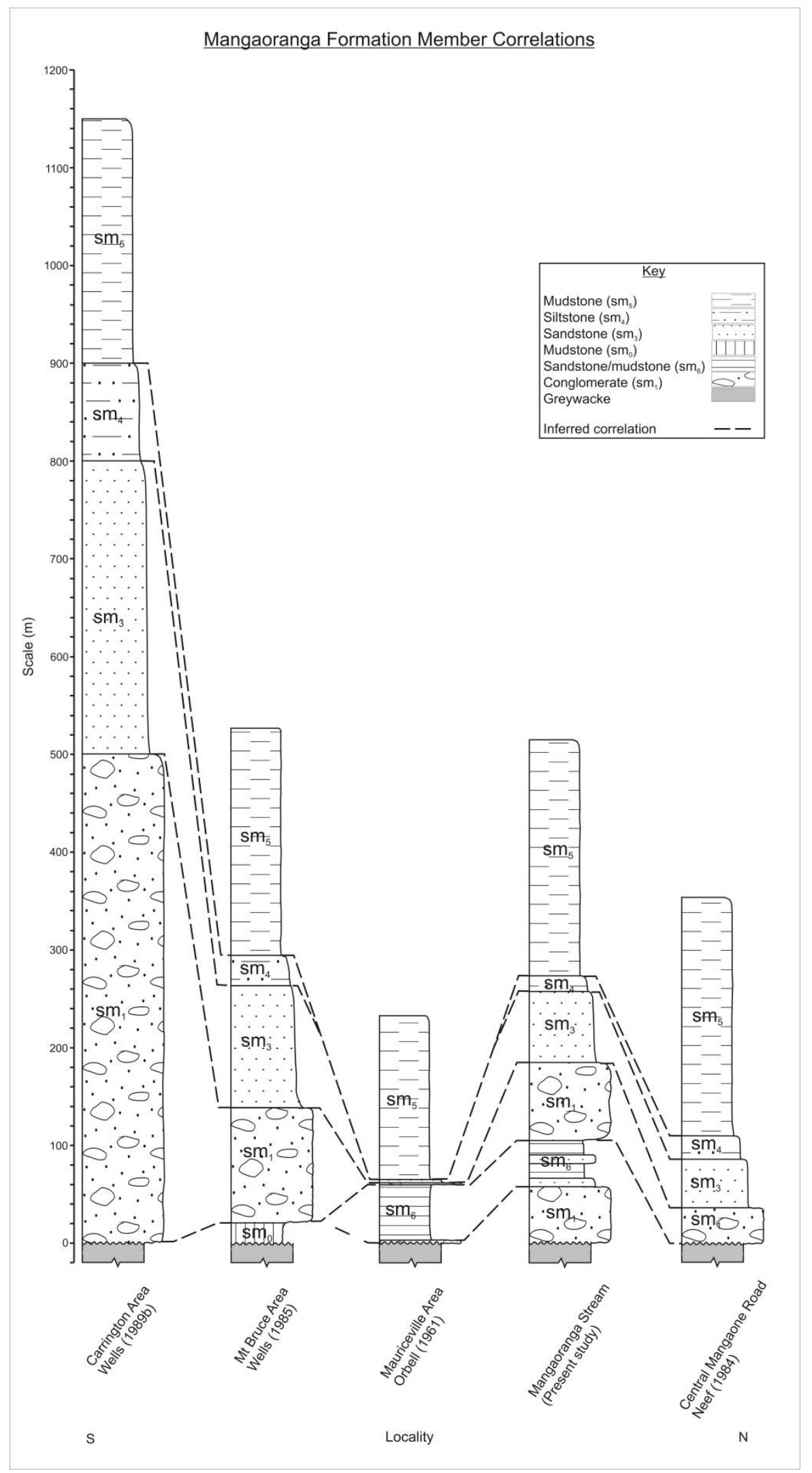

Figure 2.16: Proposed correlation of the members of the Mangaoranga Formation from five separate localities based on lithological descriptions. 


\subsubsection{Environment of deposition}

\section{Conglomerate, $\mathrm{sm}_{1}$}

The basal member of the Mangaoranga Formation is the $\mathrm{sm}_{1}$ conglomerate (with the exception of the Mt Bruce site (Wells, 1985)). The thickness of the conglomerate is variable; however in the Carrington area it is estimated to be over $500 \mathrm{~m}$ (Wells, 1989a). The conglomerate is composed predominantly of rounded to well-rounded greywacke pebbles and boulders and fines upwards. Coarse-grained sandstone lenses are common within the conglomerate, particularly near the base. Deposition of the conglomerate is inferred to have occurred by braided rivers, due to the coarse-grained nature of deposits, blade clast form and the general rounding of the clasts. Imbrication measurements suggest paleocurrent flow to the north and north-west in Eketahuna (Neef, 1984; present study) and north-east further south (Wells, 1985; Wells, 1989a).

\section{Interbedded sandstone and mudstone, $\mathrm{sm}_{6}$}

At the Mauriceville and Mangaoranga Stream sections, between 40 and $60 \mathrm{~m}$ of terrestrial sandstone and mudstone with a thin $(<60 \mathrm{~cm})$ carbonaceous horizon overlies the $\mathrm{sm}_{1}$ conglomerate. The substantial thickness of these deposits at both localities, combined with the similar lithology and stratigraphic position above the $\mathrm{sm}_{1}$ conglomerate, has led to their correlation (interbedded sandstone and mudstone, $\left.\mathrm{sm}_{6}\right)$.

Neef (1984) suggested that deposition of this member in Mangaoranga Stream occurred in the abandoned meanders of a water course (oxbow lake). However, this interpretation is not accepted in the present study for the following reasons:

1. The preservation of up to $60 \mathrm{~m}$ of sediment in the stratigraphic record implies sedimentation of some $95 \mathrm{~m}$ of soft sediment (as mudstone compaction curves suggest a $37 \%$ porosity reduction in mudstone buried to depths of $2-$ $3 \mathrm{~km}$ with low temperatures (Puttiwongrak et al., 2013). Thus, the final compacted thickness is $63 \%$ of the initial thickness). It is highly unlikely that this scale of sedimentation would occur in the abandoned meander of a river.

2. Oxbow lake deposits typically have a fining-upwards trend with an occasional paleosol below an organic rich horizon near the top (Miall, 1996). 
If the river meanders back across the sediment infilled lake, the sequence may then be overlain by fluvial deposits. At the Mangaoranga Stream and Mauriceville sites, however, this sequence is not observed. In Mangaoranga Stream, the lignite horizon is located in the middle of $\mathrm{sm}_{6}$, while at the Mauriceville section it is located at the base. No paleosol has been recognised below either of the lignite layers. The lignite horizon is subsequently immediately overlain by mudstone at both sections. This sequence is atypical of Oxbow lake deposits.

3. It is unlikely that deposition of the $\mathrm{sm}_{1}$ conglomerate was from a meandering river, as rapid erosion of the surrounding greywacke relief leading to the deposition of coarse-grained sediments and gravels implies deposition from braided river systems. Thus, these deposits cannot be from that of an abandoned meander.

An alternative interpretation is that deposition of these deposits occurred in a substantial lake. The lake may have formed due to the development of north-south trending dip-slip faults on both the eastern western sides of the sites. Movement along these faults may have led to the development of a north-south trending depression, which subsequently filled with water leading to the formation of a large lake. The proposed fault-bound nature of this lake is analogous to modern lakes along the eastern North Island, such as Lake Poukawa, Hawkes Bay, and Lake Wairarapa, southern Wairarapa. Both lakes are located within large north-east trending coseismic depressions which are bound on both the western and eastern sides by large fault systems accommodating crustal shortening (Darby \& Beanland, 1992; Kelsey et al., 1993; Shulmeister et al., 2001).

Common sandstone, mudstone and organic laminae indicate that the lake was often flooded. The presence of the lignite layer suggests that at one point 1) the lake was heavily flooded, where a large amount of organic matter washed in, and/or 2) the water level of the lake shallowed, resulting in the formation of a swamp environment around the lake margins. In either case, lake sedimentation rates at this time were fast and/or the water was anoxic, leading to preservation of the organic matter. 
Shallowing of the lake as the result of a tectonic event and/or decrease in accommodation space eventually occurred. This resulted in the development of rivers and subsequent sedimentation of $\mathrm{sm}_{1}$ conglomerate above $\mathrm{sm}_{6}$ interbedded sandstone and mudstone. Ultimately, up to $95 \mathrm{~m}$ of soft sediment were deposited.

Although sedimentation rates in a lake environment may be extremely variable and cannot be quantified in the present case, drill core results from the analogous lakes, Lake Poukawa and Lake Wairarapa, suggest average lake sedimentation rates of 1.2 $\mathrm{m} / \mathrm{ky}$ over the past $6 \mathrm{ky}$ and $1.1 \mathrm{~m} / \mathrm{ky}$ over the past $1.6 \mathrm{ky}$ respectively (Shulmeister et al., 2001; Trodahl, 2011). By applying these rates to the present case, this implies that the Tongaporutuan lake may have persisted for about $95 \mathrm{ky}$. If the lake did infact persist for this length of time, or there abouts, this indicates that it was a fairly large feature.

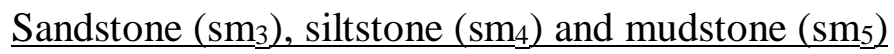

$\mathrm{Sm}_{3}$ sandstone conformably overlies the $\mathrm{sm}_{1}$ conglomerate at the sites examined in the present study. The sandstone fines upwards and is sparsely fossiliferous; containing mixed whole and fragmented Mollusca. Examination of the macrofauna suggests that deposition of $\mathrm{sm}_{3}$ occurred in a deepening shallow marine environment. The presence of Polinices and Cucullaea suggest that seas were warm during sedimentation (Neef, 1985).

Conformably overlying $\mathrm{sm}_{3}$ is $\mathrm{sm}_{4}$ siltstone. The siltstone is massive and contains sparse concretions. The coral Oculina virgosa was found within some concretions in the Mt Bruce area, indicating that deposition of the siltstone occurred in water depths of up to $100 \mathrm{~m}$ (Wells, 1985). The fine-grained nature of the siltstone above $\mathrm{sm}_{3}$ implies that deposition occurred in a deepening marine environment.

Finally, conformably overlying the $\mathrm{sm}_{3}$ and $\mathrm{sm}_{4}$ members is $\mathrm{sm}_{5}$ mudstone. The mudstone is massive and contains sparse concretions. Analysis of foraminifera from the Mangaoranga Stream section indicates deposition in a deepening marine environment, with water depths reaching a maximum of $600 \pm 300 \mathrm{~m}$ (Kennett, 1966). 
The deposits of $\mathrm{sm}_{3}, \mathrm{sm}_{4}$ and $\mathrm{sm}_{5}$ represent a marine transgressive sequence. The deposition of these members was likely the result of widespread basin subsidence, leading to deposition of $\mathrm{sm}_{5}$ in water depths of $600 \pm 300 \mathrm{~m}$ by the Late Tongaporutuan.

\section{Mt Bruce}

The basal deposits of the Mangaoranga Formation are slightly different at the Mt Bruce site than at other locations (e.g. Orbell, 1961; Neef, 1984; Wells, 1989a). Here, the basal member is Moles Mudstone $\left(\mathrm{sm}_{0}\right)$. The member dominantly consists of blue-grey mudstone and contains common plant fragments, foraminifera and Mollusca. The fossils indicate deposition in an estuarial mudflat environment, where rivers deposited brackish-water molluscs and plant fragments (Wells, 1985). Overlying Moles Mudstone is $\mathrm{sm}_{1}$ conglomerate. The conglomerate contains wellrounded greywacke clasts and has a fining-upwards trend, as at other exposures (e.g. Neef, 1984; Wells, 1989a). Near the top of the conglomerate, marine molluscs are abundant (such as Glycymeris (Grandaxinea) laticostata and Sectipecten sp.). These molluscs indicate deposition in a high energy environment. Wells (1985) interpreted the deposition of $\mathrm{sm}_{1}$ conglomerate at this locality as occurring by alluvial fans. Imbrication measurements suggest paleocurrent flow to the north to north-east (Wells, 1985).

The $\mathrm{sm}_{1}$ conglomerate at Mt Bruce grades upwards into the lower member of the transgressional sequence, sandstone $\left(\mathrm{sm}_{3}\right)$. The sandstone is then conformably overlain by siltstone $\left(\mathrm{sm}_{4}\right)$ and mudstone $\left(\mathrm{sm}_{5}\right)$ respectably (Wells, 1985). Foraminifera from $\mathrm{sm}_{5}$ indicate that deposition of this member in the Mt Bruce area occurred in water depths of $300 \mathrm{~m}$ during the Late Tongaporutuan (Wells, 1985). 


\section{CHAPTER 3}

\section{Floral analysis}

\subsection{Palynology}

\subsubsection{General introduction}

Pollen and spores are tough walled organic sacs that house the reproductive material of many plants (Traverse, 1988). Pollen is produced by seed-bearing higher plants such as angiosperms (flowering plants) and gymnosperms (cone-bearing plants such as conifers and cycads) while spores are produced by non-seed-bearing lower plants, such as pteridophytes (vascular plants such as ferns), bryophytes (mosses, liverworts and hornworts), algae and fungi. The fertilisation process for both pollen and spores is functionally different.

\section{$\underline{\text { Spores }}$}

The fertilisation processes for spores of pteridophytes and bryophytes is briefly summarised below. For a detailed description see Traverse (1988) or Playford \& Dettmann (1996).

Spore producing plants can reproduce both sexually and asexually. Plants that reproduce asexually (most pteridophytes) produce spores of one kind only and are referred to as homosporous. Sexually reproducing plants yield two distinct forms of spores and are referred to as heterosporous. Both homosporous and heterosporous plants produce capsules of sporangia on the underside of leaflets, which produce the spores. The spores are haploid and multicellular. When conditions are favourable, the spores are released from the sporangium on to suitably damp ground. For homosporous plants, the spores germinate to form a prothallus, which develops male and female reproductive organs. Fertilisation is aided by surface water films. For heterosporous plants, the two distinct forms of spores, a microspore and a megaspore, germinate to produce male and female gametophytes respectively. The gametophytes mature into male and female gametes, where, as in homosporous spores, surface water films facilitate the fertilisation process. 


\section{Pollen}

Pollen grains are male reproductive bodies that contain one-half of the genome of the parent plant (Traverse, 1988). In order for fertilisation to occur, a pollen grain must reach a female reproductive body (megasporangium) of the same plant species. The process of fertilisation is slightly different between gymnosperms and angiosperms, and is explained in detail by Shivanna \& Johri (1989) and Jarzen \& Nichols (1996). Put simply, in gymnosperms, the megasporangium produces an exposed egg which is fertilised by either a free-swimming sperm or a sperm transported down a pollen tube attached to a pollen grain. In angiosperms, the megasporangium produces a shielded egg inside the carpel of a flower. The egg is fertilised by a sperm transported down the pollen tube of a pollen grain that has landed on the flowers stigma.

\subsubsection{Dispersal techniques}

The dispersal and transport of pollen grains from a parent plant to a female receptor (pollination) occurs through wind, animal or water (secondary vector). In angiosperms, the most common vectors used are animals (zoophily) or insects (entomophily) (Jarzen \& Nichols, 1996). In some plant species, such as Astrocaryum vulgare and Urginea maritima, both wind and insect pollination occurs (ambophily) (Culley et al., 2002). In gymnosperms, wind is the common vector for pollination (anemophily) (Jarzen \& Nichols, 1996).

The dispersal and transport of spores to both receptive partners and suitable growing conditions is similar to that of pollen. Once released from the sporangium, both pteridophyte and bryophyte spores disperse by wind or water on to suitably damp ground (Playford \& Dettmann, 1996).

\subsubsection{Dispersal distances}

The distance travelled by palynomorphs (microfossils between 5 and $500 \mu \mathrm{m}$ in size used here to describe pollen and spores) during dispersal varies greatly between species and is largely related to the dispersal technique. Anemophilous plants tend 
to disperse pollen over large distances (King et al., 1975). Zoophilous and entomophilous plants disperse pollen over smaller areas, as the animal vectors do not travel great distances (King et al., 1975). For spores, the dispersal distance largely depends on the size of the grain as, in general, the larger the spore size the smaller the dispersal distance (Playford \& Dettmann, 1996).

If palynomorphs become entrained in a body of water, such as a river, stream, or the ocean, they can travel to even greater distances. For example, Scott \& van Zinderen Barker (1985) estimated that exotic anemophilous pollen found on Marion Island (southern Indian Ocean) travelled $\sim 2000 \mathrm{~km}$ by ocean currents from its source (Africa).

An understanding of palynomorph dispersal is especially important for vegetation reconstructions (Scott \& van Zinderen Barker, 1985) as it can help determine whether the flora is locally (palynomorphs with short dispersal distances) or regionally (palynomorphs with large dispersal distances) derived.

\subsubsection{Productivity}

Palynomorph productivity varies between plant species and is largely dependent on the plants dispersal technique (e.g. anemophily verse entomophily) (Jarzen \& Nichols, 1996). Anemophilous and heterosporous plants produce the largest number of palynomorphs compared to zoophilous, entomophilous and homosporous plants (King et al., 1975). This is because it is more difficult for palynomorphs produced by anemophilous and heterosporous plants to reach a compatible receptive body. Thus, in order for fertilisation to occur, a large number of palynomorphs are required to increase the likelihood of fertilisation. For zoophilous and entomophilous plants, pollen is transported directly from a parent plant to a receptive body. Thus, less pollen is required as the likelihood of any one pollen grain reaching a compatible partner is greatly increased. 


\subsubsection{Preservation}

The inert outer wall (exine) of pollen and spores is commonly preserved in the sedimentary record. Preservation depends on both the chemical composition of the palynomorph and the chemical and physical conditions of the environment of deposition (Traverse, 1988; Jarzen \& Nichols, 1996). Preservation often occurs after a palynomorph has become entrained in a body of water. Once in water, palynomorphs behave like silt-sized sediment particles, where they remain in suspension until the energy level of the water drops enough for the particles to settle out. As a result, palynomorphs deposit in low energy environments with other siltsized particles and thus are preserved in the sedimentary record within fine-grained strata (e.g. claystones, siltstones, fine-grained sandstones and shales). The chemical conditions that favour palynomorph preservation are acidic and reducing environments as, in these conditions, microbial attack is relatively low (Havinga, 1967; Traverse, 1988).

Conditions that lead to palynomorph decay include:

1) Highly oxidising environments

2) Highly alkaline environments

3) Burning

4) Diagenesis - in particular, elevated temperatures

Preferential preservation of some palynomorph species can occur during sedimentation which results in over- or under-represented species in the pollen record. Factors that can lead to a bias in the record include palynomorph productivity and exine thickness (Muller, 1981). For example, pollen from Lauraceae is often not preserved in the sedimentary record due to the pollen having a low productivity and a thin exine (Muller, 1981; Herendeen et al., 1994).

\subsubsection{Palynomorphs and vegetation reconstructions}

Fossil pollen and spores can be used to investigate the vegetation history of a region, as each species can be related to a particular plant family, genus or species, which in turn can be linked to the plants environmental preferences. 
Further complications exist when attempting to reconstruct past vegetation, as samples can contain both local and regional fossil palynomorphs. What species represents which must first be identified before quantitative vegetation reconstructions can be made. Catchment size is one major indicator as to whether flora recovered from a sample is local or regional (Tauber, 1965; Sugita, 1994; Jackson \& Kearsley, 1998). Jacobson \& Bradshaw (1981) modelled the relationship between catchment size and pollen abundances and found that, in general, the larger a catchment size, the higher the abundance of regional palynomorphs (Figure 3.1). Thus, sites with smaller catchments areas have higher abundances of local palynomorphs. Palynomorphs recovered from marine sediments typically represent regional flora, as the catchemnet size is very large, leading to palynomorph preservation some distance from the source.

Canopy cover also affects the spatial vegetation signal, as sites under closed canopy generally preserve pollen from nearby trees (local signal) whereas sites under an open canopy preserve pollen from trees growing some distance away (regional signal) (Parshall \& Calcote, 2001).

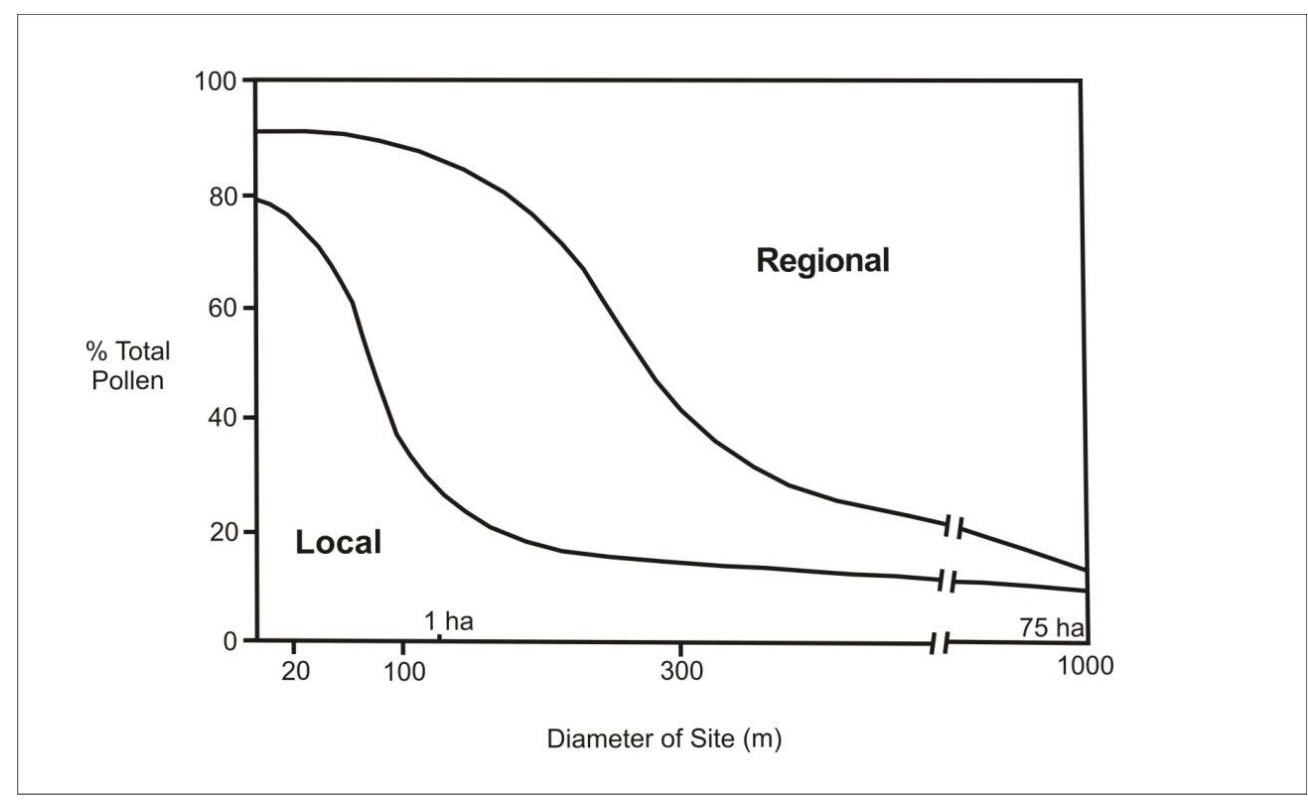

Figure 3.1: The relationship between the size of a site (that has no inflowing stream) and the relative proportion of pollen from local and regional sites. Modified after Jacobson \& Bradshaw (1981). 


\subsection{Palynological analysis}

\subsubsection{Sample collection}

Initially, eight samples were collected for pollen analysis to determine the quality of preservation and abundance of palynomorphs. After discovering the poor preservation of the grains and low abundance, it was decided that several more samples be processed. A total of thirteen samples were processed for palynological analysis from the Mangaoranga Stream, Mauriceville and Central Mangaone Road sites (Figure 2.3, Figure 2.11 and Figure 2.13, respectively). The samples were collected at irregular intervals where fine-grained sandstone, siltstone and mudstone was exposed. Each sample weighed approximately $500 \mathrm{~g}$ and was placed inside a 10 $\mathrm{cm}$ x $15 \mathrm{~cm}$ plastic zip lock bag. The samples were labelled and stored at room temperature prior to preparation. A fourteenth sample, collected from a lignite horizon on Route 52 (near Alfredton) in a previous study, was also processed for palynological analysis (Figure 1.2). The sample was initially collected for palynological analysis by James Green, however, it was never processed. Additionally, a fifteenth sample was analysed for pollen in this study. The sample was collected from Ruamahanga River, Mt Bruce, by P. E. Wells in 1984 and subsequently processes and counted by Mr D. C. Mildenhall. The slides were available for this study, thus were re-examined and included within the final results. 


\subsubsection{Sample preparation}

Two different palynological processing techniques were trialled in this study. The first technique (palynology processing technique 1) followed that outlined by Sparke et al. (1984). The second technique (palynology processing technique 2) followed that outlined by Faegri et al. (1989). Palynology processing technique 2 resulted in the best preserved palynomorphs when mounted, thus this technique was used to processes the final fourteen samples. The samples were processed in the Palynology Laboratory at Victoria University of Wellington, Wellington.

The basic processing procedure for palynology processing technique 2 is outlined below. A detailed explanation of both procedures is supplied in Appendix 1.1.

\section{Palynological processing technique 2}

1. $\sim 5 \mathrm{~g}$ of sub-sample was removed from each bulk sample and transferred into separate $50 \mathrm{ml}$ polypropylene centrifuge tubes.

2. $10 \% \mathrm{HCl}$ acid was added to each sample to remove any carbonates.

3. The samples were topped up with filtered water and washed.

Note: after each of the following steps (excluding steps 6 and 7), the residue was washed with filtered water.

4. Dilute Calgon was added to the residue to disaggregate the sediments. The samples were placed in a water-bath set at $\sim 80^{\circ} \mathrm{C}$ for 45 minutes.

5. Potassium hydroxide $(\mathrm{KOH})$ was added to the residue to separate the palynomorphs from the surrounding matrix and neutralise the humic acids. The samples were placed in a water-bath set at $\sim 80^{\circ} \mathrm{C}$ for 15 minutes.

6. To remove any water from the sample, the residue was washed twice with glacial acetic acid $\left(\mathrm{C}_{2} \mathrm{H}_{4} \mathrm{O}_{2}\right)$.

7. The residue underwent acetolysis to remove any cellulose material. The acetolysis solution was prepared with 9:1 acetic anhydride $\left(\mathrm{C}_{4} \mathrm{H}_{6} \mathrm{O}_{3}\right)$ and concentrated sulphuric acid $\left(\mathrm{H}_{2} \mathrm{SO}_{4}\right)$. The samples were placed in a water-bath set at $\sim 96^{\circ} \mathrm{C}$ for 5 minutes.

8. The residue underwent two more glacial acetic acid washes to remove any acetolysis solution from the samples. 
9. $35 \mathrm{ml}$ of 2.0 specific gravity sodium-polytungstate ( $\mathrm{SPT}, 3 \mathrm{Na}_{2} \mathrm{WO}_{4} 9 \mathrm{WO}_{3} \mathrm{H}_{2} \mathrm{O}$ ) was added to each sample to separate the organic residue from the remaining material.

10. The organic residue was sieved through a $6 \mu \mathrm{m}$ sieve cloth into $10 \mathrm{ml}$ conicalbottom centrifuge tubes.

11. Pollen mounts were made from the residue using glycerine jelly and standard glass slides and cover slips.

\subsubsection{Palynology examination and identification}

Slides were observed using a standard binocular microscope. Identification of the pollen and spores was determined using literature (Pocknall \& Mildenhall, 1984; Mildenhall \& Pocknall, 1989; Raine et al., 2011). Transects were made across the slide where the palynomorphs were recorded on a prepared counting sheet. 250 pollen and spore grains were counted in each sample for good representation. Numerous slides were examined until the count was complete.

The pollen and spores were identified to species level where possible. Where this was not possible, the taxa were identified to genus level and subsequently labelled 'spp.', or in the case of Nothofagus, 'undifferentiated'.

\subsubsection{Natural affinities and categorisation}

During the palynomorph identification process it was noted that many of the fossil taxa identified are now extinct in New Zealand. The natural affinity of these taxa was determined using literature (Raine et al., 2011), where it was found that many of the affinities can be related to extant ancestors both overseas and in New Zealand. Using information on the natural affinity, the pollen and spores in each sample were categorised, where possible, into the following groups:

- Arboreal pollen: pollen from trees (excludes tree and ground ferns, shrubs and herbs).

○ Beech - Nothofagus, subgenus Fuscospora (Nothofagus fusca type) and Brassospora (Nothofagus brassi type) pollen. 
- Nothofagus fusca type: Nothofagidites lachlaniae and undifferentiated Fuscospora.

- Nothofagus brassi type: Nothofagidites cranwelliae, Nothofagidites matauraensis, Nothofagidites falcatus and Nothofagidites spinosus.

○ Podocarp-hardwoods - Araucariacites australis, Bombacacidites bombaxoides, Dacrydiumites praecupressinoides, Myrtaceidites mesonesus, Microalatidites paleogenicus, Podocarpus spp. and Proteacidites minimus.

○ Swamp-associated - Arecipites otagoensis, Arecipites spp., Dacrycarpites australiensis, Liliacidites variegatus and Rhopalostylis sapida.

- Other arboreal pollen (tree pollen not included in the above categories) Malvacearumpollis mannanensis, Myricipites harrisii, Myrtaceidites eugeniioides, Proteaceae spp. and Reevesiapollis reticulatus.

- $\quad$ Tree ferns

- Cyathea type, Cibotiidites tuberculiformis and Foveotriletes verrucosus.

- Ground ferns

○ Baculatisporites spp., Gemmatriletes multiglobus, Gleicheniidites senonicus, Polypodiaceoisporites papuanus, Polypodiaceoisporites tumulatus, Polypodiisporites inangahuensis, Polypodiisporites variscabratus, Polypodiisporites minimus, Polypodiisporites radiatus, Polypodiisporites spp., Rugulatisporites cowrensis and monolete spp.

- Shrub pollen

○ Asteraceae spp., Ericipites longisulcatus, Gothanipollis gothani, Malvacipollis subtilis, Palaeocoprosmadites zelandiae, Tubulifloridites antipodica, Tubulifloridites pleistocenicus and Tubuliflorae spp.

- Herb pollen

- Cyperaceaepollis neogenicus, Foveotriletes lacunosus, Glencopollis ornatus, Haloragacidites amolosus, Ligulifloridites sp., Liliacidites spp., Monogemmites gemmatus, Ricciaesporites kawaraensis, Sparganiaceaepollenites barungensis, Sparganiaceaepollenites sphericus and Tubulifloridites simplis. 
- Grass-like pollen

- Graminidites media.

- Woody climber and epiphyte pollen

- Lateropora glabra, Monogemmites sp. and Parsonsidites psilatus.

- Unknown natural affinity (pollen with an unknown natural botanical affinity)

- Cranwellia striata, Gothanipollis bassensis, Rhoipites alveolatus, Rhoipites spp., Tricolporites scabratus, Tricolporites spp., Triorites minor and Triorites spp.

\subsubsection{Graphing the results}

For every sample, the percentage of pollen and spores in each category was calculated out of the total sample assemblage. The results were graphed in bar-graph form using Excel. The arboreal pollen sub-category (e.g. podocarp-hardwood) percentage in each sample was also calculated, where the percentage of pollen in each sub-category was calculated out of the total arboreal pollen assemblage. These results were also graphed in bar-graph form using Excel. 


\subsection{Paleobotany}

\subsubsection{Sample collection and preparation}

A mudstone bed directly above the lignite horizon in Mangaoranga Stream was found to contain mummified leaves (Figure 2.3). These leaves have not been recorded in the Mangaoranga Formation before.

Multiple samples of the mudstone and enclosed leaves were collected for paleobotanical analysis (Figure 3.2). The samples were wrapped in plastic clingwrap, placed inside a box and stored in the School of Geography, Environment and Earth Sciences cold room $\left(4^{\circ} \mathrm{C}\right)$ at Victoria University of Wellington, Wellington, before preparation.

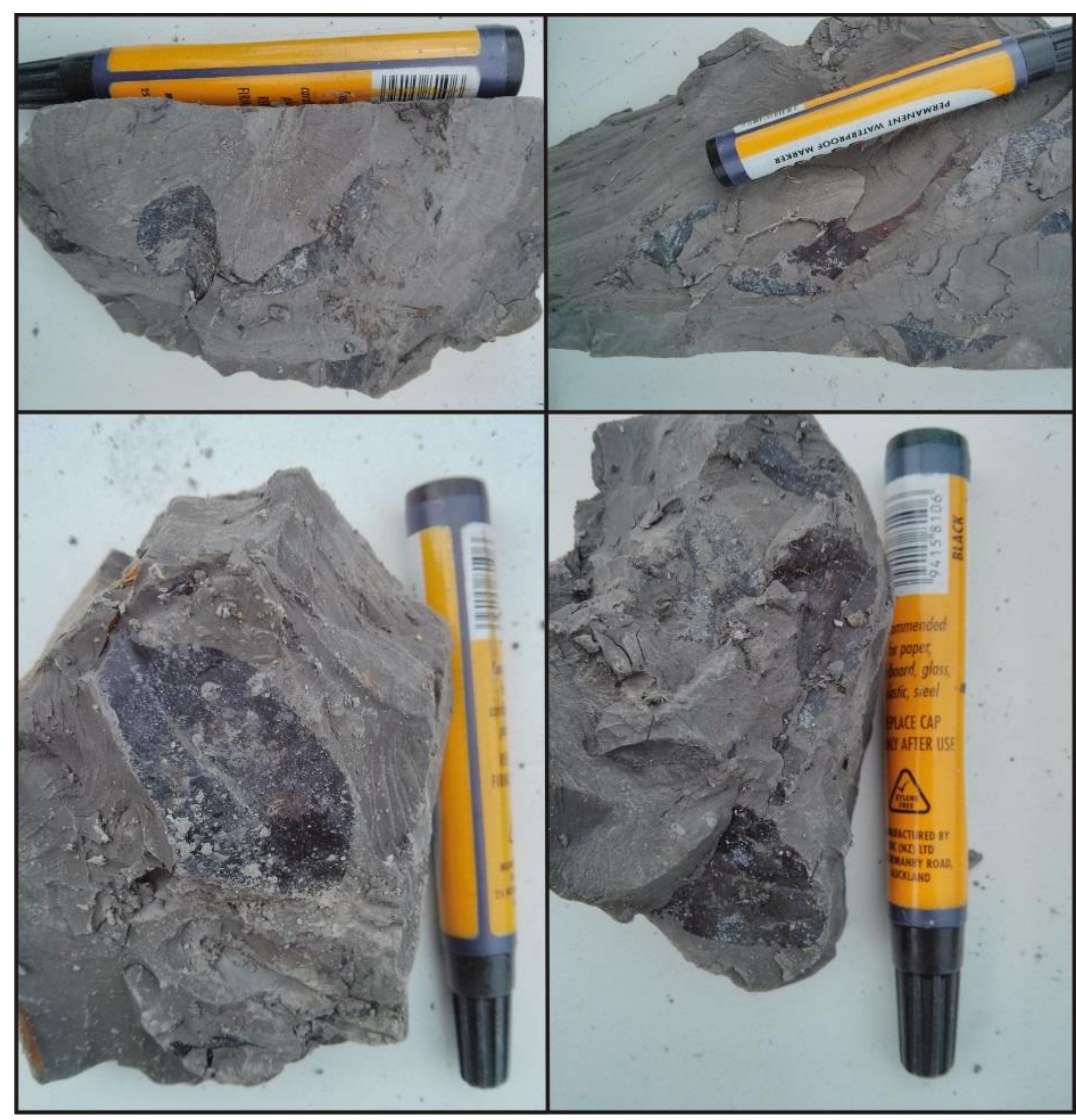

Figure 3.2: Photographs of unidentified mummified fossil leaves found directly above the lignite horizon in Mangaoranga Stream, Eketahuna. 


\section{Processing technique}

The leaves were processed using standard techniques by Aline Homes.

The leaves were separated from the matrix where possible and cleared in $6 \% \mathrm{H}_{2} \mathrm{O}_{2}$, then brushed gently to remove sediment. The leaves were mostly too fragile to remove intact, so cleared pieces were mounted on glass slides in glycerine jelly to display fine details. Cuticles were prepared from leaf fragments by maceration of small pieces of sediment in $6 \% \mathrm{H}_{2} \mathrm{O}_{2}$ with a few crystals of sodium pyrophosphate, washed to remove sediment particles, stained in saffranine and mounted in glycerine jelly. The slides were examined and photomicrographs made with a Leica DMLB microscope fitted with a Leica DFC 280 camera. Preparation of plates for analysis is currently in progress (A. Homes, personal communication, February $1^{\text {st }}, 2014$ ).

The leaves were identified by comparison with specimens of leaves and cuticles of living New Zealand plants and with published and unpublished illustrations of living and fossil leaves and cuticles from New Zealand and overseas (Holden 1982b; 1983; Williams et al., 1984; Bannister et al., 2012) (A. Homes, personal communication, February $\left.1^{\text {st }}, 2014\right)$. 


\subsection{Floral results}

\subsubsection{Palynology results}

A total of fourteen samples were processed for paleontological analysis in this study, of which, twelve samples contained enough pollen for a count of 250 grains to be made from each. The remaining two samples contained either no pollen (KH1304) or extremely scarce pollen (KH1308d). A fifteenth sample collected by P. E. Wells and processed by Mr D. C. Mildenhall was also examined in the present study. The results of the palynological analysis are summarised below. Due to the lack of marker horizons and age constraints, the time interval between samples is unknown. Thus, it is unknown how the results correlate between sections. The results are laid out in stratigraphic order at each site. A full taxonomic list of the pollen and spores identified in each sample is supplied in Appendix 1.2. Photographs are supplied in Appendix 1.3.

\section{Contamination}

Significant care was taken to minimise the risk of contamination during sample collection and processing which included, 1) removing the outer $3 \mathrm{~cm}$ of the outcrop before sampling, 2) vigorously cleaning all laboratory items before use, 3) using filtered or distilled water and 4) covering the samples immediately after handling. However two of the fourteen samples processed (KH1306 and KH1308a) contained low levels of the contaminant Pinus. This level of contamination does not affect the reliability of the results. The contaminant grains were recorded in the full taxonomic list (Appendix 1.2); however they were not included in the samples final count. 


\section{Alfredton sample}

The Alfredton sample is characterised by high levels of arboreal pollen (64\%), with moderately low levels of shrub pollen (16\%: entirely of Palaeocoprosmadites zelandiae) (Figure 3.2).

The arboreal pollen assemblage contains high levels of both podocarp-hardwood $(52 \%)$ and swamp-associated taxa (39\%), with low levels of beech (3\%: Nothofagus brassi type and undifferentiated Nothofagus) and 'other arboreal pollen' (6\%: Malvacearumpollis mannanensis, Myricipites harrisii, Myrtaceidites eugeniioides and Proteaceae spp.) (Figure 3.3). The podocarp-hardwood assemblage consists entirely of Myrtaceidites mesonesus, while the swamp-associated assemblage contains common Arecipites (Arecipites otagoensis and Rhopalostylis sapida) and Liliacidites variegatus.

$14 \%$ of the pollen grains in this sample have no known natural affinity. These grains consist mostly of Rhoipites (Rhoipites alveolatus and Rhoipites spp.), with traces of Tricolporites spp. Traces of monolete ground fern spores are also present, along with traces of herb pollen Sparganiaceaepollenites sphericus and Sparganiaceaepollenites barungensis. 


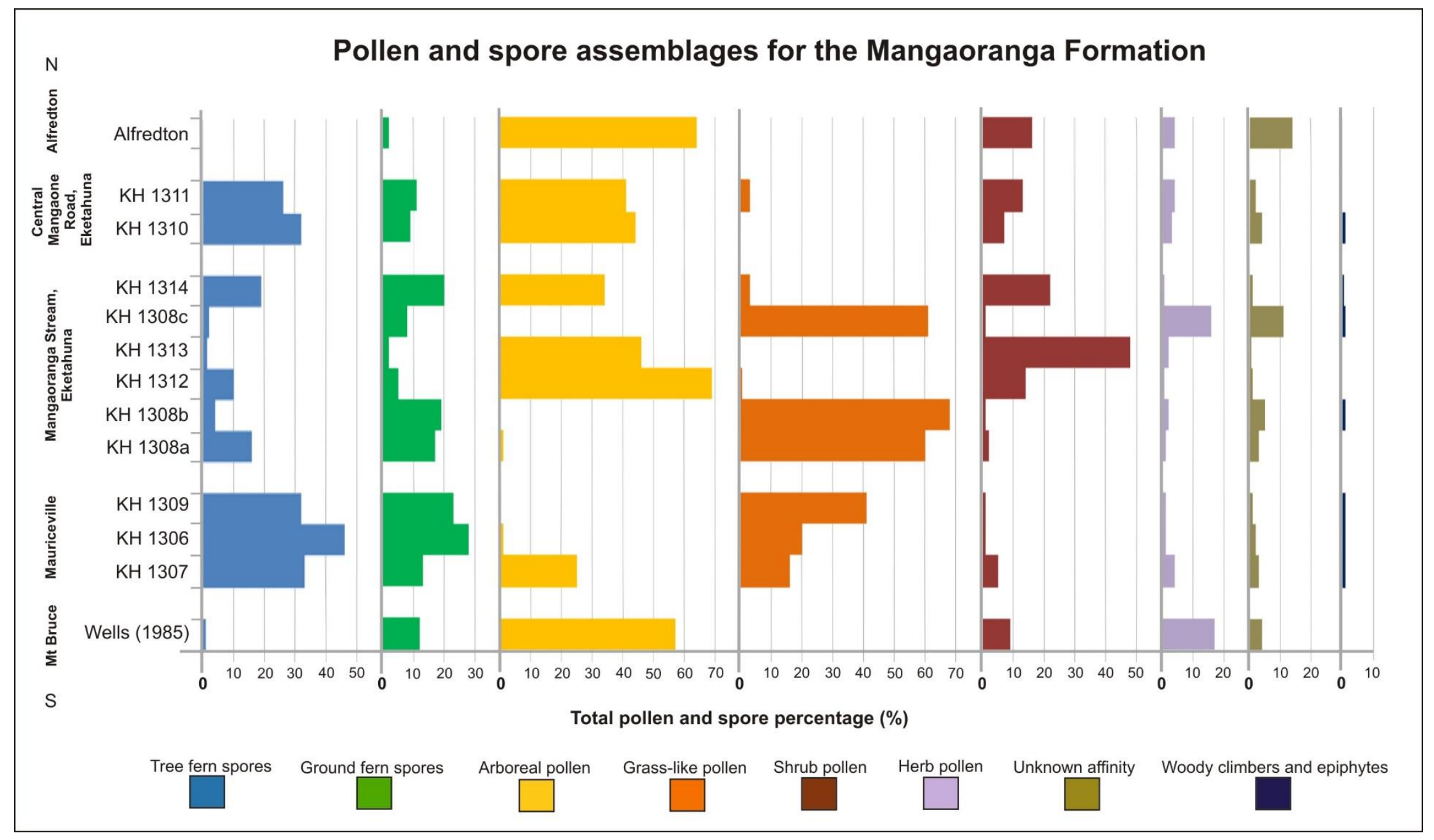

Figure 3.3: Pollen and spore assemblages for samples processed from the Mangaoranga Formation at the Mauriceville, Mangaoranga Stream, Central Mangaone Road and Alfredton sites. The results of a sample processed by Wells (1985) from the Mt Bruce area and examined in the present study are also displayed. 


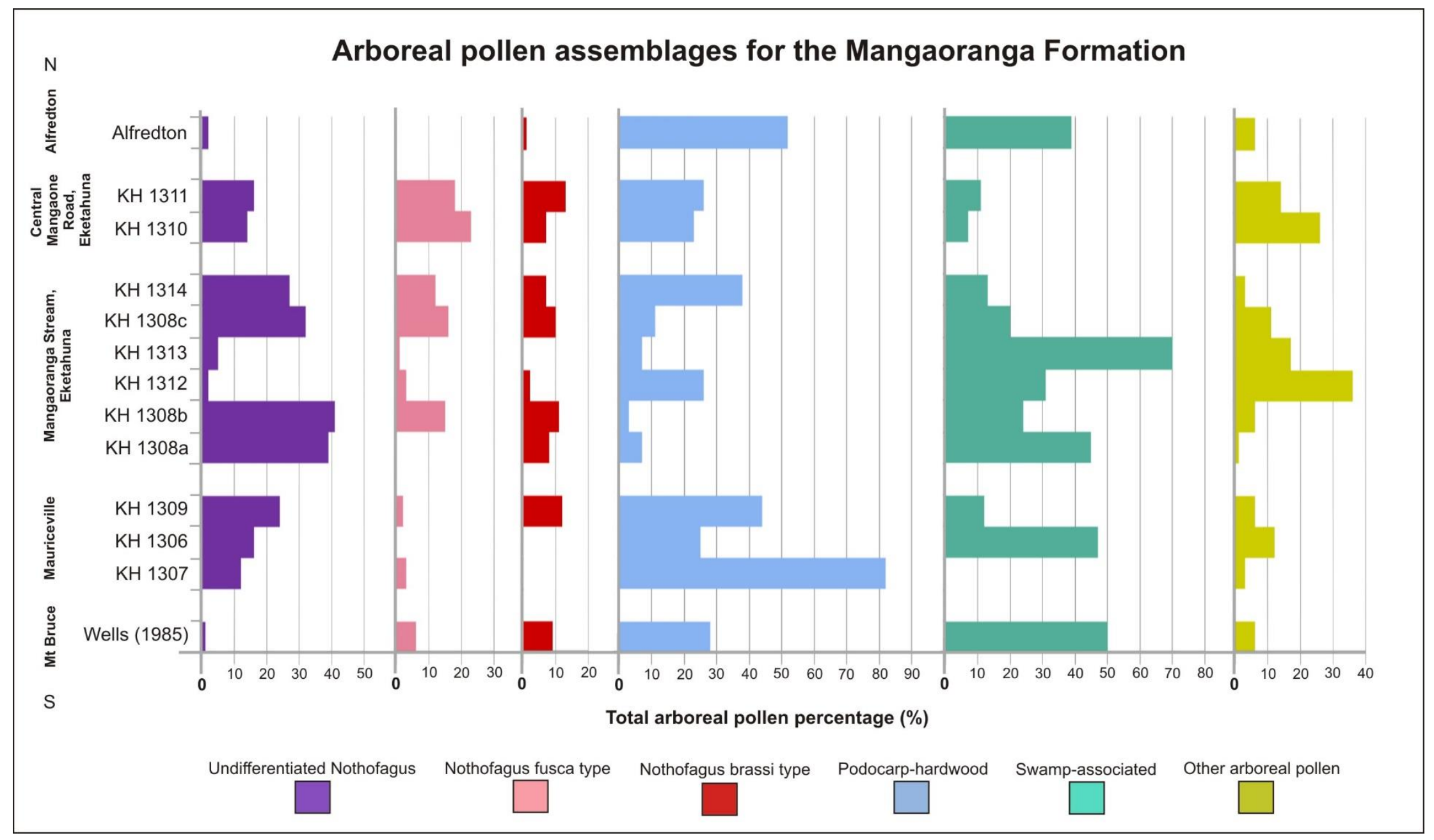

Figure 3.4: Arboreal pollen assemblages for samples processed from the Mangaoranga Formation at the Mauriceville, Mangaoranga Stream, Central Mangaone Road and Alfredton sites. The results of a sample processed by Wells (1985) from the Mt Bruce area and examined in the present study are also displayed. 


\section{Central Mangaone Road section}

KH1310

The total pollen assemblage (Figure 3.3) recovered from KH1310 is characterised by a high concentration of arboreal pollen (44\%) and tree fern spores (32\%).

The arboreal pollen assemblage (Figure 3.4) contains moderate levels of beech (44\%), 'other arboreal pollen' (26\%) and podocarp-hardwood taxa (23\%), with traces of swamp-associated pollen (7\%: Arecipites otagoensis, Rhopalostylis sapida, Dacrycarpites australiensis and Liliacidites variegatus). The beech assemblage (Figure 3.4) contains common Nothofagus fusca type pollen, with low levels of Nothofagus brassi type and undifferentiated beech-like species. The remaining part of the arboreal pollen assemblage (Figure 3.4) contains equal amounts of Myricipites harrisii (40\%) and Malvacearumpollis mannanensis (40\%), with traces of Proteaceae spp. (10\%) and Reevesiapollis reticulatus (10\%), while the podocarphardwood assemblage contains nearly equal amounts of Dacrydiumites praecupressinoides (46\%) and Myrtaceidites mesonesus (54\%).

Low levels of ground fern spores (9\%: monoletes and Polypodiisporites spp, Figure 3.3) and shrub pollen (9\%: Palaeocoprosmadites zelandiae, Tubulifloridites antipodica, Tubulifloridites pleistocenicus and Tubulifloridites simplis) are also present in KH1310, along with traces of Monogemmites gemmatus, Tricolporites spp., and woody climber pollen Parsonsidites psilatus.

\section{KH1311}

Although KH1311 yielded high levels of arboreal pollen (41\%, Figure 3.3) and tree fern spores (26\%), they are present in slightly decreased concentrations compared to KH1310 (44\% and 32\% respectively).

The arboreal pollen assemblage (Figure 3.4) consists primarily of beech taxa (47\%), comprising 39\% Nothofagus fusca type (Nothofagidites lachlaniae), 27\% Nothofagus brassi type (Nothofagidites cranwelliae and Nothofagidites matauraensis) and 34\% undifferentiated Nothofagus. Podocarp-hardwood pollen (Figure 3.4) makes up $26 \%$ of the arboreal pollen assemblage, and contains mostly Dacrydiumites praecupressinoides, with traces of Myrtaceidites mesonesus and 
Podocarpus spp. Swamp-associated taxa (11\%) and 'other arboreal pollen' (14\%) are also common (Figure 3.4). The swamp-associated assemblage contains both Arecipites (Arecipites otagoensis and Rhopalostylis sapida) and Dacrycarpites australiensis. The remaining 'other arboreal pollen' assemblage contains common Malvacearumpollis mannanensis and Myricipites harrisii, with traces of Proteaceae spp.

The ground fern spore (11\%) and shrub (13\%) pollen concentration (Figure 3.3) in KH1311 have slightly increased compared with KH1310 (9\% and 7\% respectively). As in KH1310, the ground fern spore assemblage is entirely made up of monoletes and Polypodiisporites sp., and similarly, the shrub pollen assemblage is dominated by Palaeocoprosmadites zelandiae, with traces of Tubulifloridites pleistocenicus and Tubulifloridites simplis.

Traces of herb pollen Ligulifloridites sp., Glencopollis ornatus and Ricciaesporites kawaraensis are also present in KH1311, as well as traces of grass-like pollen Graminidites media, and Tricolporites spp. which have unknown natural affinity. 
Mangaoranga Stream section

KH1308a

KH1308a yielded a high concentration of arboreal pollen (62\%) (Figure 3.3), primarily from beech (46\%) and swamp-associated trees (24\%) (Figure 3.4).

The beech pollen (Figure 3.4) consists of both Nothofagus brassi type (17\%: Nothofagidites falcatus, Nothofagidites matauraensis and Nothofagidites cranwelliae,) and undifferentiated Nothofagus (83\%), while the swamp-associated pollen contains common Arecipites (Arecipites otagoensis and Rhopalostylis sapida) and Liliacidites variegatus. Arboreal podocarp-hardwood pollen (Dacrydiumites praecupressinoides, Microalatidites paleogenicus, Proteacidites minimus and Podocarpus spp., Figure 3.4) makes up only $6 \%$ of the total arboreal pollen assemblage, while the 'other arboreal pollen' assemblage makes up only $1 \%$ (Malvacearumpollis mannanensis).

The tree ( $16 \%)$ and ground (17\%) fern spore concentrations (Figure 3.3) are nearly equal in KH1308a. The tree fern assemblage consists primarily of Cyathea type spores, while the ground fern assemblage is slightly more variable, containing primarily monoletes, as well as Polypodiisporites sp., Gleicheniidites senonicus and Rugulatisporites cowrensis.

Traces of shrub pollen Palaeocoprosmadites zelandiae, Asteraceae spp. and Ericipites longisulcatus are also present in KH1308a, as well as traces of Graminidites media, Gothanipollis bassensis, Rhoipites alveolatus and Tricolporites scabratus.

KH1308b

KH1308b contains a very high concentration of arboreal pollen (68\%) (Figure 3.3), $67 \%$ of which are assigned to beech taxa, consisting of mostly undifferentiated Nothofagus pollen (Figure 3.4), with low levels of Nothofagusfusca and Nothofagus brassi type pollen.

The arboreal pollen assemblage (Figure 3.4) also contains common swampassociated taxa (24\%), as well as rare podocarp-hardwood (3\%) and 'other arboreal 
pollen' (6\%: Malvacearumpollis mannanensis and Myricipites harrisii). The swamp-associated assemblage includes Arecipites (Arecipites otagoensis, Rhopalostylis sapida and Arecipites spp.), Liliacidites variegatus and Dacrycarpites australiensis, while the podocarp-hardwood pollen assemblage contains Myrtaceidites mesonesus, Proteacidites minimus and Podocarpus spp.

The tree fern spore concentration (Figure 3.3) in KH1308b (4\%) has significantly decreased from KH1308a ( 16\%), while the ground fern spore (19\%, Figure 3.3) concentration has slightly increased. Traces of shrub pollen Tubuliflorae (Tubulifloridites pleistocenicus, Tubulifloridites simplis and Tubuliflorae spp.) are present in KH1308b, as well as herb pollen Sparganiaceaepollenites sphericus, woody climber pollen Lateropora glabra, and Triorites spp., Cranwellia striata and Tricolporites spp.

\section{KH1312}

KH1312 has the highest concentration of arboreal (69\%, Figure 3.3) pollen of any of the fifteen samples.

Unlike KH1308a and KH1308b, the arboreal pollen (Figure 3.4) in KH1312 is dominated by 'other arboreal pollen' (36\%), swamp-associated taxa (31\%), and podocarp-hardwood $(26 \%)$ pollen, with only a trace of beech $(7 \%)$.

The 'other arboreal pollen assemblage' largely contains Myricipites harrisii, with traces of Myrtaceidites eugeniioides, Proteaceae spp., and Malvacearumpollis mannanensis. The swamp-associated assemblage largely consists of Arecipites (Arecipites otagoensis and Rhopalostylis sapida), while the podocarp-hardwood assemblage is dominated by Myrtaceidites mesonesus, with low values of Dacrydiumites praecupressinoides and Podocarpus spp.

The shrub pollen (14\%) and tree fern spore (10\%) concentrations (Figure 3.3) in KH1312 have increased compared with KH1308b (2\% and 4\% respectively), while the ground fern spore (5\%) concentration has decreased. The shrub pollen assemblage is almost entirely made up of Palaeocoprosmadites zelandiae, with 
traces of Gothanipollis gothani. Traces of Sparganiaceaepollenites sphericus, Graminidites media, and Rhoipites are also present in KH1312.

\section{KH1313}

The highest concentration of shrub pollen (48\%, Figure 3.3) of any of the fifteen samples was recovered from KH1313. The shrub pollen assemblage is entirely made up of Palaeocoprosmadites zelandiae, with traces of Gothanipollis gothani.

The arboreal pollen (45\%, Figure 3.3) concentration in KH1313 is also high, however it has decreased in concentration from KH1312 (69\%). The arboreal pollen assemblage (Figure 3.4) is dominated by swamp-associated taxa (70\%), with lower levels of 'other arboreal pollen' (17\%), podocarp-hardwood (7\%) and beech pollen (6\%). The swamp-associated pollen assemblage primarily consists of Rhopalostylis sapida, with lower values of Arecipites otagoensis and Liliacidites variegatus, while the 'other arboreal pollen' assemblage consists of Myricipites harrisii and Proteaceae spp. The podocarp-hardwood assemblage is entirely made up of Myrtaceidites mesonesus while the beech assemblage is made up of Nothofagus fusca type pollen and undifferentiated Nothofagus.

The tree (2\%) and ground (2\%) fern spore concentrations (Figure 3.3) are decreased in $\mathrm{KH} 1313$ from $\mathrm{KH} 1312$ (10\% and 5\% respectively), as is the herb pollen (2\%, Figure 3.3) concentration, which is represented by Sparganiaceaepollenites barungensis.

\section{KH1308c}

The palynomorph assemblage from $\mathrm{KH} 1308 \mathrm{c}$ is characterised by a high concentration of arboreal pollen (61\%, Figure 3.3), which includes $58 \%$ beech (Figure 3.4), 20\% swamp-associated, 11\% podocarp-hardwood and $11 \%$ 'other arboreal pollen'. The beech group (Figure 3.4) consists of both Nothofagus fusca and Nothofagus brassi type pollen (Nothofagidites cranwelliae, Nothofagidites falcatus, Nothofagidites matauraensis and Nothofagidites spinosus), with a large number of undifferentiated Nothofagus taxa. The swamp-associated pollen consists primarily of Arecipites (Arecipites otagoensis and Rhopalostylis sapida) with traces 
of Liliacidites variegatus, while the podocarp-hardwood assemblage is made up entirely of Myrtaceidites mesonesus. 'Other arboreal pollen' includes Myricipites harrisii and Reevesiapollis reticulatus.

The shrub pollen assemblage (16\%, Figure 3.3) in KH1308c contains abundant Palaeocoprosmadites zelandiae and rare Asteraceae spp. The ground fern spore concentration (8\%, Figure 3.3) has slightly increased in KH1308c from KH1313 $(2 \%)$, while the tree fern $(2 \%$, Figure 3.3$)$ spore concentration has remained almost the same. Pollen with an unknown natural affinity makes up $11 \%$ of the total pollen assemblage of KH1308c (Figure 3.3), and consists of Rhoipites (Rhoipites alveolatus and Rhoipites spp.), Tricolporites (Tricolporites scabratus and Tricolporites spp.) and Triorites (Triorites minor and Triorites spp.). Traces of herb pollen Sparganiaceaepollenites barungensis and epiphyte pollen Monogemmites sp. are also present in KH1308c.

\section{KH1314}

KH1314 is characterised by high levels of arboreal pollen (34\%, Figure 3.3), with moderate levels of shrub pollen (22\%) and tree (19\%) and ground (20\%) fern spores. The arboreal pollen concentration in KH1313 has decreased from KH1308c (61\%), while the shrub, tree and ground fern components of the assemblages have increased.

The arboreal pollen assemblage (Figure 3.4) contains high values of beech (46\%) and podocarp-hardwood pollen (38\%), with lower levels of swamp-associated (13\%) and 'other arboreal pollen' (3\%). The beech pollen assemblage (Figure 3.4) contains both Nothofagus fusca and Nothofagus brassi type taxa; however it is dominated by undifferentiated Nothofagus. High levels of Dacrydiumites praecupressinoides and Myrtaceidites mesonesus are present within the podocarp-hardwood pollen assemblage, with traces of Podocarpus spp. The swamp-associated assemblage contains both Rhopalostylis sapida and Liliacidites variegatus while the other arboreal pollen' assemblage contains traces of Proteaceae spp. and Myricipites harrisii,

High levels of Palaeocoprosmadites zelandiae are present within the shrub pollen assemblage, along with traces of Gothanipollis gothani. The ground fern spore 
assemblage is made up entirely of monoletes and Polypodiisporites sp. while the tree fern spore assemblage is largely made up of Cyathea type spores, with low levels of Cibotiidites tuberculiformis. Traces of grass-like pollen Graminidites media are also present in KH1314, along with Ligulifloridites sp., Parsonsidites psilatus and Tricolporites spp. 
Mauriceville section

KH1307

The assemblage (Figure 3.3) from KH1307 is characterised by high values of tree fern spores (34\%; Cyathea type) and grass-like pollen (24\%; Graminidites media). The grass-like pollen (Figure 3.3) is more abundant in KH1307 than in any other sample. On the other hand arboreal pollen makes up $16 \%$ of the total pollen assemblage (Figure 3.3), the lowest abundance of all samples.

The arboreal pollen assemblage (Figure 3.4) consists dominantly of podocarphardwood pollen (82\%), with low levels of beech (13\%) and 'other arboreal pollen' (3\%; Malvacearumpollis mannanensis). The podocarp-hardwood assemblage contains common Dacrydiumites praecupressinoides, with traces of Podocarpus spp. The beech pollen assemblage (Figure 3.4) consists of both Nothofagus fusca type and undifferentiated Nothofagus taxa.

Ground fern spores (13\%, Figure 3.3) are also common in KH1307 and consist of monoletes and various Polypodiisporites spp. Low levels of herbaceous (4\%, Figure 3.3) pollen are present in KH1307, with the assemblage dominated by Ligulifloridites sp. Traces of shrub pollen Palaeocoprosmadites zelandiae, Asteraceae spp. and Tubuliflorae spp. are also present in KH1307, as well as woody climber pollen Parsonsidites psilatus, and Rhoipites (Rhoipites alveolatus and Rhoipites spp.), of unknown natural affinity.

\section{KH1306}

KH1306 yielded the highest concentration of tree ( 46\%) and ground (28\%) fern spores of all the samples (Figure 3.3), with the ground fern percentage more than doubling when compared with KH1307 (13\%). The tree fern assemblage is entirely composed of Cyathea type (91\%) and Cibotiidites tuberculiformis (9\%) while the ground fern assemblage has abundant Polypodiisporites sp. (57\%) and monoletes (43\%). KH1306 also has increased values of arboreal pollen (20\%, Figure 3.3), up from KH1307 (16\%).

Swamp-associated (47\%), podocarp-hardwoods (25\%), beech (16\%) and other arboreal pollen (12\%: Myricipites harrisii) were recorded in KH1306 (Figure 3.4). 
The swamp-associated pollen contains common Arecipites (Rhopalostylis sapida) and Liliacidites spp. while the podocarp-hardwood assemblage contains common Dacrydiumites praecupressinoides and Podocarpus spp., with traces of Myrtaceidites mesonesus. Traces of herb pollen Haloragacidites amolosus and Monogemmites gemmatus are also present in KH1306, as well as grass-like pollen Graminidites media, woody climber pollen Parsonsidites psilatus, shrub pollen Tubuliflorae spp., and Tricolporites spp. and Triorites spp.

\section{KH1309}

The assemblage from KH1309 (Figure 3.3) is characterised by high values of arboreal pollen (41\%) and tree fern spores $(31 \%)$. The tree fern spore concentration is slightly lower than in KH1306 ( 46\%) but it is still made up entirely of Cyathea type (71\%) and Cibotiidites tuberculiformis (29\%) spores.

The arboreal pollen concentration (Figure 3.4) increases from KH1306 (20\%), and includes increased values of podocarp-hardwoods (44\%) and beech (38\%), with decreased values of swamp-associated pollen (12\%: Dacrycarpites australiensis and Liliacidites variegatus). The podocarp-hardwood assemblage is dominated by Dacrydiumites praecupressinoides, with low values of Podocarpus spp. and Microalatidites paleogenicus. The beech pollen assemblage (Figure 3.4) is made up of Nothofagus brassi (33\%: including Nothofagidites cranwelliae, Nothofagidites matauraensis and Nothofagidites spinosus) and Nothofagus fusca type pollen (5\%), as well as various undifferentiated Nothofagus taxa (62\%). 'Other arboreal pollen' (6\%) includes Malvacearumpollis mannanensis and Proteaceae spp.

The ground fern spore (23\%, Figure 3.3) concentration decreased from KH1306 (28\%), and includes common monoletes and Polypodiisporites (Polypodiisporites inangahuensis, Polypodiisporites variscabratus, Polypodiisporites radiates and Polypodiisporites spp.), with rare Baculatisporites. Traces of shrub pollen Palaeocoprosmadites zelandiae and Asteraceae spp., herb pollen Foveotriletes lacunosus and Monogemmites gemmatus, and Cranwellia striata and Parsonsidites psilatus are also present in KH1309. 


\section{Mt Bruce sample}

The Mount Bruce sample (Figure 3.3) is characterised by high levels of arboreal $(57 \%)$ pollen, with moderate levels of herb pollen (17\%).

The arboreal pollen assemblage (Figure 3.4) contains abundant swamp-associated taxa $(50 \%)$, with common podocarp-hardwood $(28 \%)$ and beech pollen $(16 \%)$. The swamp-associated assemblage is entirely made up of Arecipites otagoensis, while the podocarp-hardwood assemblage contains mostly Bombacacidites bombaxoides pollen, with traces of Araucariacites australis, Myrtaceidites mesonesus and Microalatidites paleogenicus. The beech assemblage (Figure 3.4) contains common Nothofagus brassi (Nothofagidites cranwelliae) and Nothofagus fusca type pollen (Nothofagidites lachlaniae), with a low level of undifferentiated Nothofagus. 'Other arboreal pollen' $(6 \%)$ in this sample includes Myricipites harrisii and Proteaceae spp.

The herb pollen assemblage (Figure 3.3) is dominated by Sparganiaceaepollenites barungensis, with low levels of Cyperaceaepollis neogenicus, Glencopollis ornatus and Glencopollis ornatus. Ground fern spores (Figure 3.3) make up 12\% of the total pollen assemblage in the Mount Bruce sample, and consist of monoletes, Polypodiisporites spp. and Baculatisporites. Low levels of shrub pollen (9\%, Figure 3.3) are present in this sample, with the assemblage dominated by Palaeocoprosmadites zelandiae. Low levels of Malvacipollis subtilis, Tubulifloridites pleistocenicus and Rhoipites are also present. 


\subsubsection{Palynology results summary}

The samples examined in the present study were found to contain diverse pollen and spore assemblages. The Central Mangaone Road samples contain very similar pollen and spore assemblages with only slightly differing percentages. These assemblages are primarily made up of tree fern spores and arboreal pollen from beech trees. The Mangaoranga Stream samples contain high values of arboreal pollen, largely from beech and swamp-associated taxa, while the Mauriceville samples contain high values of tree and ground fern spores, with significantly less arboreal pollen. The arboreal pollen assemblage at the Mauriceville section has a large representation from podocarp-hardwoods, especially Dacrydiumites praecupressinoides. The two samples examined from the lignitic horizon (Alfredton and KH1313) were found to have high concentrations of arboreal pollen. The arboreal pollen assemblages are largely made up of swamp-associated taxa and podocarp-hardwood pollen. Shrub pollen in these two samples was also fairly common, and was almost entirely (if not completely) made up of Palaeocoprosmadites zelandiae. KH1307 was found to have a slightly different pollen assemblage to the other samples, as it was largely composed of herb and grass-like pollen. However, despite the significantly different assemblage in KH1307, the remaining samples were found to contain very similar pollen and spore taxa.

Pollen identified for the first time in the Mangaoranga Formation are:

Foveotriletes lacunosus, Foveotriletes verrucosus, Rugulatisporites cowrensis, Gleicheniidites senonicus, Polypodiaceoisporites papuanus, Nothofagidites falcatus, Reevesiapollis reticulatus, Gothanipollis bassensis, Gothanipollis gothani and Triorites minor. 


\subsubsection{Paleobotany results}

Much of the work on the leaves is on-going and thus only several preliminary results presented here.

Initial examinations of the mummified leaves found within the mudstone matrix show the presence of broadleaved monocotyledon remains and leaves from up to three species of Lauraceae. The species of Lauraceae do not closely resemble present-day New Zealand Lauraceae. The monocotyledonous remains are fragmentary and the gross morphology is not particularly diagnostic. Cuticular fragments examined to date suggest affinities with Arecaceae (palms) or Pandanaceae (screw-pines) (A. Homes, personal communication, February $1^{\text {st }}$, 2014). 


\subsection{Floral discussion}

\subsubsection{Reconstructing the vegetation cover}

Based on the reasonable assumption that fossil taxa have similar ecological affinities to modern genera, an environmental reconstruction for the area can be attempted. In some cases, where the pollens natural affinity is unknown (such as with Rhoipites), the ecological interpretation can be based on the environmental analysis of the enclosing sediments.

When determining the natural affinity of the palynomorphs, often the lowest taxonomic identification possible was to genus (occasionally to family) level. As a result, many of the ecological interpretations are broad, as a number of species with varied habitats can be included in a genus. To allow for this, several possible habitats are suggested for some taxa. Additionally, ecological interpretations from previous studies on sediments of similar age from around New Zealand were also taken into account. The natural affinities and habitats of the pollen and spores identified in the present study are listed in Table 1.

Table 1: List of pollen and spores identified in the present study with their age range and inferred natural affinity and habitat.

\begin{tabular}{|l|c|l|l|}
\hline Pollen and spores & Age range & Natural affinity & Habitat \\
\hline Tree ferns & - & Tree ferns & $\begin{array}{l}\text { Forest understory, } \\
\text { colonise along } \\
\text { stream and river } \\
\text { sides. }\end{array}$ \\
\hline Ground ferns & - & Ground ferns & $\begin{array}{l}\text { Forest floors and } \\
\text { open areas. }\end{array}$ \\
\hline Podocarp-hardwoods & $\begin{array}{l}\text { Nriassic to } \\
\text { Aeogene }\end{array}$ & Araucaria, Agathis & $\begin{array}{l}\text { Coastal and low- } \\
\text { lying forest, river } \\
\text { terraces, canopy } \\
\text { component. }\end{array}$ \\
\hline Araucariacites australis & & \multicolumn{2}{|l}{} \\
\hline
\end{tabular}




\begin{tabular}{|c|c|c|c|}
\hline $\begin{array}{l}\text { Bombacacidites } \\
\text { bombaxoides }\end{array}$ & $\begin{array}{l}\text { Paleogene } \\
\text { to Neogene }\end{array}$ & Bombax & $\begin{array}{l}\text { Forests, river and } \\
\text { stream terraces. } \\
\text { Humid } \\
\text { environment. }\end{array}$ \\
\hline $\begin{array}{l}\text { Dacrydiumites } \\
\text { praecupressinoides }\end{array}$ & $\begin{array}{l}\text { Cretaceous } \\
\text { to Neogene }\end{array}$ & $\begin{array}{l}\text { Dacrydium } \\
\text { cupressinum type }\end{array}$ & $\begin{array}{l}\text { Lowland to } \\
\text { montane forests, } \\
\text { canopy/over story } \\
\text { on moist well } \\
\text { drained soil. }\end{array}$ \\
\hline Myrtaceidites mesonesus & $\begin{array}{l}\text { Paleogene } \\
\text { to Modern }\end{array}$ & Metrosideros spp. & $\begin{array}{l}\text { Lowland and } \\
\text { coastal forests, } \\
\text { occasionally } \\
\text { around lake } \\
\text { margins. }\end{array}$ \\
\hline Microalatidites paleogenicus & $\begin{array}{l}\text { Paleogene } \\
\text { to Neogene }\end{array}$ & Phyllocladus & $\begin{array}{l}\text { Lowland and } \\
\text { montane forests, on } \\
\text { exposed ridges and } \\
\text { infertile soils. } \\
\text { Occasionally } \\
\text { around bog } \\
\text { margins. }\end{array}$ \\
\hline Podocarpus spp. & $\begin{array}{l}\text { Jurassic to } \\
\text { Modern }\end{array}$ & Podocarpus spp. & $\begin{array}{l}\text { Lowland to alpine } \\
\text { forests, Canopy } \\
\text { flora. }\end{array}$ \\
\hline Proteacidites minimus & $\begin{array}{l}\text { Cretaceous } \\
\text { to Neogene }\end{array}$ & Knightia excelsa & $\begin{array}{l}\text { Lowland and } \\
\text { coastal forests, } \\
\text { lower montane } \\
\text { shrubland. Canopy } \\
\text { component on dry } \\
\text { soils. }\end{array}$ \\
\hline \multicolumn{4}{|l|}{ Beech } \\
\hline $\begin{array}{l}\text { Nothofagus Subgenus } \\
\text { Fuscospora }\end{array}$ & $\begin{array}{l}\text { Paleogene } \\
\text { to Modern }\end{array}$ & $\begin{array}{l}\text { Nothofagus fusca } \\
\text { type }\end{array}$ & $\begin{array}{l}\text { Montane and } \\
\text { lowland forests. } \\
\text { Moist, cool } \\
\text { temperate climate. }\end{array}$ \\
\hline $\begin{array}{l}\text { Nothofagus Subgenus } \\
\text { Brassospora }\end{array}$ & $\begin{array}{l}\text { Paleogene } \\
\text { to } \\
\text { Pleistocene }\end{array}$ & $\begin{array}{l}\text { Nothofagus brassi } \\
\text { type }\end{array}$ & $\begin{array}{l}\text { Montane and } \\
\text { lowland forests. } \\
\text { Moist, warm } \\
\text { temperate climate. }\end{array}$ \\
\hline
\end{tabular}




\begin{tabular}{|c|c|c|c|}
\hline Swamp-associated & & & \\
\hline Arecipites otagoensis & $\begin{array}{l}\text { Paleogene } \\
\text { to Neogene }\end{array}$ & Arecaceae (palms) & $\begin{array}{l}\text { Lowland forests, } \\
\text { sub-canopy, } \\
\text { canopy or over- } \\
\text { story component. } \\
\text { Occasionally form } \\
\text { stands. Moist } \\
\text { environment. }\end{array}$ \\
\hline $\begin{array}{l}\text { Arecipites cf. Rhopalostylis } \\
\text { sapida }\end{array}$ & $\begin{array}{l}\text { Paleogene } \\
\text { to Neogene }\end{array}$ & $\begin{array}{l}\text { Rhopalostylis } \\
\text { sapida }\end{array}$ & $\begin{array}{l}\text { Lowland and } \\
\text { coastal forests, sub- } \\
\text { canopy, canopy or } \\
\text { over-story } \\
\text { component. } \\
\text { Occasionally form } \\
\text { stands. Moist, } \\
\text { damp shaded soils. }\end{array}$ \\
\hline Dacrycarpites australiensis & $\begin{array}{l}\text { Paleogene } \\
\text { to Neogene }\end{array}$ & $\begin{array}{l}\text { Dacrycarpus } \\
\text { dacrydioides }\end{array}$ & $\begin{array}{l}\text { Lowland swampy } \\
\text { forests and flood } \\
\text { plains. Over-story } \\
\text { component. }\end{array}$ \\
\hline Liliacidites variegatus & $\begin{array}{l}\text { Cretaceous } \\
\text { to Neogene }\end{array}$ & $\begin{array}{l}\text { Laurelia } \\
\text { novaezelandiae }\end{array}$ & $\begin{array}{l}\text { Lowland swampy } \\
\text { forests and stream- } \\
\text { sides as over-story } \\
\text { component. }\end{array}$ \\
\hline Other arboreal pollen & & & \\
\hline $\begin{array}{l}\text { Malvacearumpollis } \\
\text { mannanensis }\end{array}$ & $\begin{array}{l}\text { Paleogene } \\
\text { to Neogene }\end{array}$ & Malvaceae spp. & $\begin{array}{l}\text { Lowland forests } \\
\text { and understory } \\
\text { component, } \\
\text { colonising in open } \\
\text { areas. }\end{array}$ \\
\hline Myricipites harrisii & $\begin{array}{l}\text { Paleogene } \\
\text { to Neogene }\end{array}$ & Casuarinaceae spp. & $\begin{array}{l}\text { Flanks lowland } \\
\text { forest margins, } \\
\text { open areas and } \\
\text { along river banks, } \\
\text { nutrient-poor soils. }\end{array}$ \\
\hline Myrtaceidites eugeniioides & $\begin{array}{l}\text { Paleogene } \\
\text { to Neogene }\end{array}$ & $\begin{array}{l}\text { Eucalyptus } \\
\text { gummifera }\end{array}$ & $\begin{array}{l}\text { Coastal flats and } \\
\text { low hills, open } \\
\text { forests, sandy } \\
\text { gravelly to loamy } \\
\text { sandy soils. }\end{array}$ \\
\hline
\end{tabular}




\begin{tabular}{|c|c|c|c|}
\hline Proteaceae spp. & $\begin{array}{l}\text { Cretaceous } \\
\text { to Modern }\end{array}$ & Proteaceae spp. & $\begin{array}{l}\text { Forests, lowland, } \\
\text { nutrient-poor soils. }\end{array}$ \\
\hline Reevesiapollis reticulatus & $\begin{array}{l}\text { Neogene to } \\
\text { Pleistocene }\end{array}$ & Reevesia, Ungeria & $\begin{array}{l}\text { Forest understory } \\
\text { component, river } \\
\text { banks. }\end{array}$ \\
\hline \multicolumn{4}{|l|}{ Shrub pollen } \\
\hline Asteraceae spp. & $\begin{array}{l}\text { Tertiary to } \\
\text { modern }\end{array}$ & Asteraceae spp. & Widespread. \\
\hline Tubuliflorae spp. & $\begin{array}{c}\text { Early } \\
\text { Miocene to } \\
\text { Modern }\end{array}$ & Tubuliflorae spp. & Widespread. \\
\hline Tubulifloridites antipodica & $\begin{array}{c}\text { Early } \\
\text { Miocene to } \\
\text { Modern }\end{array}$ & $\begin{array}{l}\text { Barnadesioideae } \\
\text { spp. }\end{array}$ & $\begin{array}{l}\text { Coastal to montane } \\
\text { shrubland. }\end{array}$ \\
\hline $\begin{array}{l}\text { Tubulifloridites } \\
\text { pleistocenicus }\end{array}$ & Neogene & Cassinia arcuata & $\begin{array}{l}\text { Forest and } \\
\text { woodland } \\
\text { understory } \\
\text { component, poor } \\
\text { soils. }\end{array}$ \\
\hline Tubulifloridites simplis & Neogene & Tubuliflorae spp. & Widespread. \\
\hline Ericipites longisulcatus & $\begin{array}{l}\text { Late Eocene } \\
\text { to Neogene }\end{array}$ & Dracophyllum & $\begin{array}{l}\text { Coastal to } \\
\text { subalpine forests, } \\
\text { shrubland, } \\
\text { grassland, scrub } \\
\text { and bogs. }\end{array}$ \\
\hline Gothanipollis gothani & Neogene & Loranthaceae spp. & $\begin{array}{l}\text { Forest, mistletoe } \\
\text { habit, } \\
\text { hemiparasitic. }\end{array}$ \\
\hline Gothanipollis bassensis & $\begin{array}{l}\text { Paleogene } \\
\text { to Neogene }\end{array}$ & Loranthaceae spp. & $\begin{array}{l}\text { Forest, mistletoe } \\
\text { habit, } \\
\text { hemiparasitic. }\end{array}$ \\
\hline Malvacipollis subtilis & $\begin{array}{l}\text { Paleogene } \\
\text { to Neogene }\end{array}$ & $\begin{array}{l}\text { Euphorbiaceae } \\
\text { spp. }\end{array}$ & Widespread. \\
\hline $\begin{array}{l}\text { Palaeocoprosmadites } \\
\text { zelandiae }\end{array}$ & $\begin{array}{l}\text { Paleogene } \\
\text { to Neogene }\end{array}$ & Coprosma spp. & $\begin{array}{l}\text { Coastal to alpine } \\
\text { forests, forest } \\
\text { margins, scrubland } \\
\text { and grassland. }\end{array}$ \\
\hline
\end{tabular}




\begin{tabular}{|c|c|c|c|}
\hline & & & $\begin{array}{l}\text { Tolerates infertile } \\
\text { soil. }\end{array}$ \\
\hline \multicolumn{4}{|l|}{ Herb pollen } \\
\hline Cyperaceaepollis neogenicus & $\begin{array}{l}\text { Neogene to } \\
\text { Modern }\end{array}$ & Cyperaceae spp. & $\begin{array}{l}\text { Wetlands, swamps, } \\
\text { river flats, coastal } \\
\text { sand-dunes, forests, } \\
\text { scrub. }\end{array}$ \\
\hline Glencopollis ornatus & Neogene & $\begin{array}{l}\text { Polygonum } \\
\text { amphibium }\end{array}$ & Wetlands. \\
\hline Haloragacidites amolosus & Neogene & Haloragis & $\begin{array}{l}\text { Coastal to montane } \\
\text { forests, scrubland } \\
\text { and wetlands. }\end{array}$ \\
\hline Ligulifloridites sp. & $\begin{array}{c}\text { Late } \\
\text { Miocene to } \\
\text { Modern }\end{array}$ & Taraxacum & Widespread. \\
\hline Liliacidites spp. & $\begin{array}{l}\text { Cretaceous } \\
\text { to Neogene }\end{array}$ & Liliaceae spp. & Widespread. \\
\hline Monogemmites gemmatus & $\begin{array}{l}\text { Paleogene } \\
\text { to Neogene }\end{array}$ & $\begin{array}{l}\text { Amaryllidaceae } \\
\text { cf./ Liliaceae }\end{array}$ & Damp soils. \\
\hline $\begin{array}{l}\text { Sparganiaceaepollenites } \\
\text { barungensis }\end{array}$ & $\begin{array}{l}\text { Paleogene } \\
\text { to Neogene }\end{array}$ & Typha & Wetlands. \\
\hline $\begin{array}{l}\text { Sparganiaceaepollenites } \\
\text { sphericus }\end{array}$ & $\begin{array}{l}\text { Paleogene } \\
\text { to Neogene }\end{array}$ & Sparganium & Wetlands. \\
\hline \multicolumn{4}{|l|}{ Grass-like pollen } \\
\hline Graminidites media & $\begin{array}{l}\text { Tertiary to } \\
\text { Modern }\end{array}$ & Poaceae spp. & $\begin{array}{l}\text { Widespread, } \\
\text { grasslands, open } \\
\text { areas. }\end{array}$ \\
\hline \multicolumn{4}{|l|}{$\begin{array}{l}\text { Woody climbers and } \\
\text { epiphyte pollen }\end{array}$} \\
\hline Lateropora glabra & $\begin{array}{l}\text { Paleogene } \\
\text { to Modern }\end{array}$ & Freycinetia & $\begin{array}{l}\text { Rainforests, coastal } \\
\text { forests and humid } \\
\text { mountain forests. }\end{array}$ \\
\hline Monogemmites sp. & Neogene & Astelia & $\begin{array}{l}\text { Lowland to low } \\
\text { alpine forests, } \\
\text { scrubland, }\end{array}$ \\
\hline
\end{tabular}




\begin{tabular}{|l|c|l|l|}
\hline & & & $\begin{array}{l}\text { grassland and } \\
\text { herbfields. }\end{array}$ \\
\hline Parsonsidites psilatus & $\begin{array}{c}\text { Paleogene } \\
\text { to } \\
\text { Pleistocene }\end{array}$ & $\begin{array}{l}\text { Parsonsia } \\
\text { straminea }\end{array}$ & Forest tree climber. \\
\hline Unknown natural affinity & $\begin{array}{c}\text { Cretaceous } \\
\text { to Neogene }\end{array}$ & Dicotyledonae & \\
\hline Cranwellia striata & $\begin{array}{c}\text { Paleogene } \\
\text { to Neogene }\end{array}$ & Dicotyledonae & Swamp \\
environment.
\end{tabular}

Palynomorph representation

It is likely that the vegetation reconstructions in the present study have been skewed to over-represent pollen and spores with higher productivity and thicker exines while under-representing palynomorphs with low productivity and thin exines. This is particualy notable with Lauraceae, as speices of Lauraceae were identified in the preliminary paleobotnay examination; however, not in the palynology examination due to the species having a thin exine. The preservation of over- and underrepresented palynomorphs is an issue commonly faced when reconstructing the vegetation of an area based on fossil palynomorphs. The likelihood of skewed results is high and little can be done to change this. 


\section{Alfredton sample}

The Alfredton sample was collected from a lignite horizon and contains a large number of taxa characteristic of swamp environments (palm trees, Laurelia novaezelandiae, Rhoipites alveolatus, Typha and Sparganium) (Figure 3.4). The high concentration of swamp taxa indicates that much of the flora recovered from this sample is locally derived. This is supported by the presence of swamp plants with low dispersal distances, such as Typha, Sparganium and Rhoipites. A schematic reconstruction of the floral assemblage recovered from this section is illustrated in Figure 3.5.

The Alfredton sample contains abundant pollen from Metrosideros spp. These taxa are inferred to have grown close to the depositional site as either the dominant canopy component within surrounding coastal forests, or as lianes (Wilmshurst et al., 2004).

Low levels of beech (Nothofagus brassi type) and Eucalyptus gummifera pollen were recovered from this sample. These trees may have grown in localised areas within the Metrosideros spp. forest as sub-dominant canopy components. The forest floor component would have been made up of ground ferns, as a low level of ground fern spores were recovered from this section.

Moderate levels of pollen from swamp-associated vegetation Laurelia novaezelandiae and palm trees (including Rhopalostylis sapida) were recovered from this sample (Figure 3.4). This vegetation likely occupied forested areas with impeded drainage flanking the depositional site (Enright \& Watson, 1992). Laurelia novaezelandiae may have also grown within the swampy depositional site itself, as it occasionally grows in standing water (Dawson \& Sneddon, 1969).

Common sub-canopy components within the surrounding forests may have included Coprosma spp. and Malvaceae spp. The Malvaceae species would have grown close to the depositional site as this family is typically insect or animal pollinated, however it is likely that plants from this family was also widespread (Franceschinelli, 2005; Abid et al., 2010). Other widespread vegetation may have included Casuarinaceae spp. (Dawson \& Sneddon, 1969). Species from this family likely flanked the forest 
margins, possibly growing in marginal zones surrounding the depositional site, along stream and river banks, or within coastal woodland forests (Pocknall, 1990).

On the margins of the swamp, wetland herbs Typha and Sparganium grew. These herbs likely grew in shallow standing water, with Typha possibly forming pure stands. The low concentration of pollen from these herbs suggests that only a limited development occurred around the swamp.

Other swamp plants were those represented by Rhoipites pollen (Rhoipites alveolatus and Rhoipites undifferentiated). This pollen has an unknown natural affinity, but is commonly found in Middle Tertiary marsh and swamp deposits in Southland and Central Otago (Pocknall, 1982). Thus, although the natural affinity is unknown, it can be inferred from the environmental interpretation of the surrounding sediments that the pollen grains came from local swamp-characteristic vegetation.

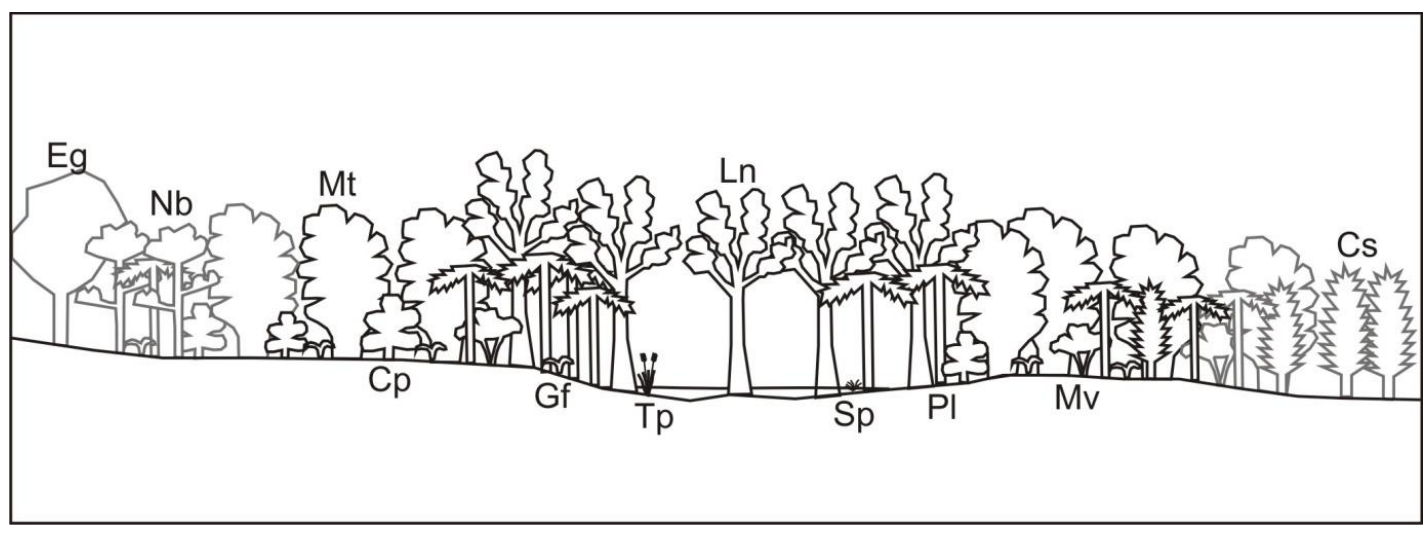

Figure 3.5: Schematic reconstruction of the Late Miocene vegetation from a lignite horizon in the Alfredton area. The black outline represents local vegetation while the grey outline represents regional vegetation. $\mathrm{Nb}=$ Nothofagus brassi type beech; $\mathrm{Ln}=$ Laurelia novaezelandiae; $\mathrm{Mt}=$ Metrosideros spp.; $\mathrm{Eg}=$ Eucalyptus gummifera; $\mathrm{Cs}=$ Casuarinaceae spp.; $\mathrm{Pl}=$ palm trees; $\mathrm{Cp}=$ Coprosma spp.; $\mathrm{Mv}=$ Malvaceae spp.; $\mathrm{Gf}=$ ground ferns; $\mathrm{Tp}=$ Typha and $\mathrm{Sp}=$ Sparganium . 


\section{Central Mangaone Road section}

The flora recovered from KH1310 and KH1311 is clearly regional as the samples were collected from marine mudstone deposited in an off shore setting (Figure 2.13). This is supported by the high concentration of anemophilous pollen recovered, such as Nothofagus, Podocarpus spp., Dacrydiumites praecupressinoides, Myricipites harrisii and Palaeocoprosmadites zelandiae.

The samples contain both warm (Nothofagus brassi type and palms) and cool temperate climate indicators (Nothofagus fusca type, podocarps, Coprosma spp. and grasses), as well as abundant taxa indicating a wet environment (fern spores, beech, Casuarinaceae spp., Polygonum amphibium, Laurelia novaezelandiae and Dacrycarpus dacrydioides). The mixed warm and cool temperate flora is inferred to represent differences in elevation, where the cool temperate taxa occupied inland areas of higher relief while the warm temperate taxa occupied lowland and coastal areas. A schematic reconstruction of the regional vegetation is illustrated in Figure 3.6 .

Samples from the Central Mangaone Road section contain a high concentration of Nothofagus pollen (both Nothofagus fusca and Nothofagus brassi types) (Figure 3.4). This indicates that a beech forest was likely dominant in the region. The presence of both Nothofagus fusca and Nothofagus brassi type pollen indicates that the beech forest would have transitioned from one dominant subgenus (Nothofagus brassi type) to the other (Nothofagus fusca type) as the relief increased.

Moderate levels of arboreal pollen from podocarp-hardwoods Dacrydium cupressinum type and Metrosideros spp. indicate that these species were important components of the low-lying forested area (Figure 3.4). Both taxa may have been common as over-story components within the forest, with Dacrydium cupressinum type occupying areas with moist, well-drained soil (Norton et al., 1988). Some Metrosideros spp. may have also occupied areas with higher elevations (Southern Rata) or been the dominant component within a coastal woodland forest, along with Casuarinaceae spp. (Lynch et al., 1972; Stewart \& Veblen, 1982).

Closer to the coast, along the forest edge and possibly partially inland, palms (including Rhopalostylis sapida) and Casuarinaceae spp. were common. The palm 
trees may have occupied soils with impeded drainage (Enright \& Watson, 1992), suggesting that water saturated areas were present within the forest. This is supported by the presence of pollen from swamp dwellers Laurelia novaezelandiae and Dacrycarpus dacrydioides. However, the low level of pollen from these species suggests that the water saturated areas may have been limited in extent.

Abundant sub-canopy components within the forested region include Coprosma spp. and tree ferns, which may have also colonised stream and river sides (Pocknall \& Turnbull, 1989). Moderate levels of pollen from Malvaceae spp. suggest that this vegetation may have also been a common sub-canopy component, while rare pollen from Cassinia arcuata, which today occupies the understories of Australian forests and woodlands (Campbell, 1990), indicates that this shrub was present but not a dominant sub-canopy component.

Low levels of pollen from both Loranthaceae spp. (known for its wide range of plants with a mistletoe habit (Ladley \& Kelly, 1996) and Parsonsia straminea were also recorded. The presence of these taxa suggests that woody climbers and hemiparasitic mistletoes were present within the lowland forested region, probably close to the coast as these plants are zoophilous and entomophilous (Ladley \& Kelly, 1996; Turner \& Hawkeswood, 1996).

Growing upon the forest floor would have been several species of ground ferns, as a moderate to low level of ground fern spores of various kinds were recorded. Wetland herbs are inferred to have grown in localised wetlands near the coast. 


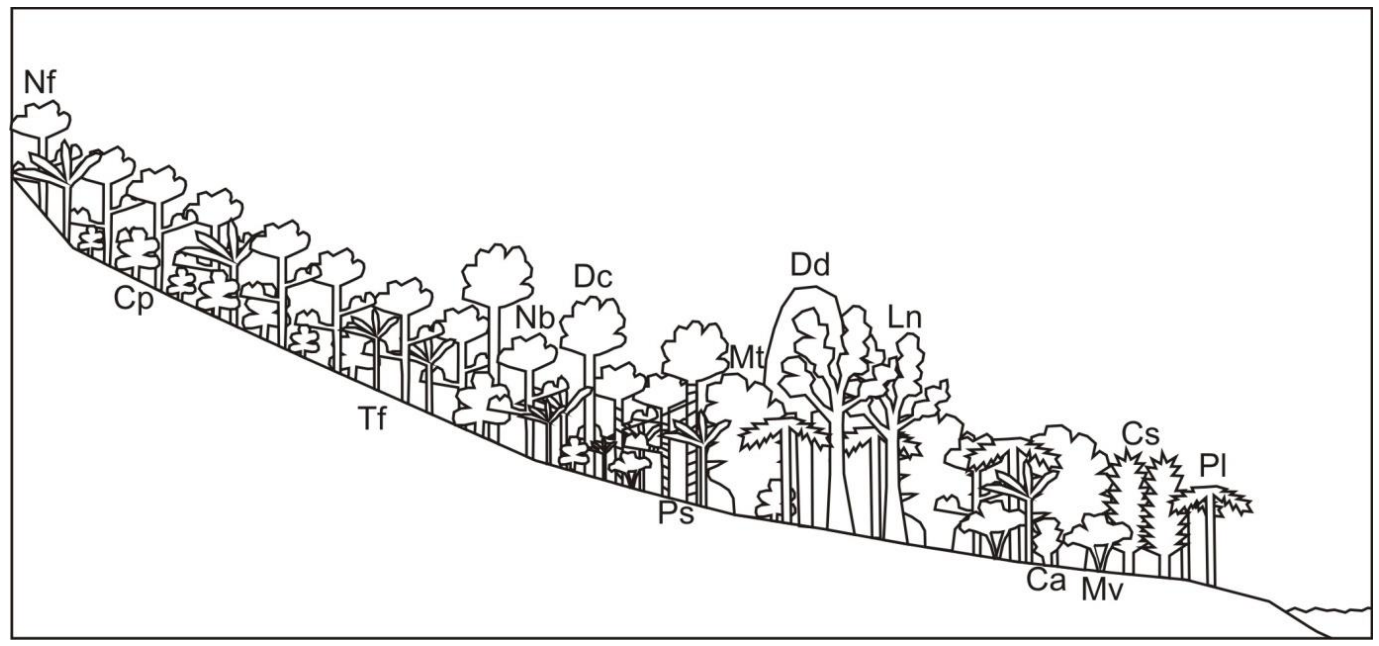

Figure 3.6: Schematic reconstruction of the Late Miocene regional vegetation in the Central Mangaone Road area, from palynology results. $\mathrm{Nf}=$ Nothofagus fusca type beech; $\mathrm{Nb}=$ Nothofagus brassi type beech; $\mathrm{Dc}=$ Dacrydium cupressinum type; $\mathrm{Dd}=$ Dacrycarpus dacrydioides $; \mathrm{Ln}=$ Laurelia novaezelandiae; $\mathrm{Mt}=$ Metrosideros spp $; \mathrm{Cs}$ = Casuarinaceae spp.; $\mathrm{Pl}=$ palm trees; $\mathrm{Tf}=$ tree ferns; $\mathrm{Cp}=$ Coprosma $\mathrm{spp}$; $\mathrm{Ca}=$ Cassinia arcuata $; \mathrm{Mv}=$ Malvaceae spp. and $\mathrm{Ps}=$ Parsonsia straminea . 
Mangaoranga Stream section

KH1308a and KH1308b

Samples KH1308a and KH1308b were collected from terrestrial mudstone and contain both warm (Nothofagus brassi type, Dacrydium cupressinum type and palms) and cool temperate climate indicators (Nothofagus fusca type, Phyllocladus, Podocarpus spp. and Coprosma spp.) (Figure 2.3). The assemblage also contains mixed anemophilous (beech, podocarps, Coprosma spp.), zoophilous (Freycinetia and Loranthaceae spp.) and entomophilous (Malvaceae) species. Due to the diversity of the pollen and spore assemblage recovered, the taxa from these samples are inferred to be both regional and local. As with the Central Mangaone Road samples, the cool temperate element is inferred to have grown in areas at higher elevations, while the warm temperate element grew in low-lying and coastal areas (Figure 3.7). The assemblage also contains many species indicating a wet environment (beech and palms, Laurelia novaezelandiae, Dacrycarpus dacrydioides, Sparganium spp. and Rhoipites alveolatus).

Abundant beech tree pollen (roughly equal amounts of Nothofagus fusca and Nothofagus brassi types) was recovered from these samples (Figure 3.4). The beech trees would have formed the dominant canopy component within the regional forests. As in the Central Mangaone Road samples, trees with Nothofagus fusca type pollen would have occupied areas with high relief, while trees with Nothofagus brassi type pollen occupied warmer areas at lower elevations.

Sub-dominant canopy vegetation within the cool temperate beech forest may have included the cool climate indicator Phyllocladus, and possibly also Podocarpus spp. (Mildenhall, 1989). Very low levels of pollen from these species were recorded in these samples, suggesting they were limited in extent.

Low levels of pollen from Dacrydium cupressinum type, Knightia excelsa and Metrosideros spp. were recorded in these samples. These species likely grew in the warmer low-lying areas in the region, possibly close to the coast (Norton et al., 1988; Yee \& Mitchell, 1991; Wilmshurst et al., 2004), with Dacrydium cupressinum type occupying areas with moist, well-drained soils (Norton et al., 1988). Along the forest 
margins, likely flanking areas of the depositional site or along river banks on nutrient poor soils, Casuarinaceae spp. grew (Ferguson et al., 2010).

Moderate to low levels of pollen from swamp tree Laurelia novaezelandiae were recorded in these samples, with traces of Dacrycarpus dacrydioides. These species were likely growing in low-lying forested areas with water saturated soils (Dawson $\&$ Sneddon, 1969). The low level of pollen from Dacrycarpus dacrydioides indicates that this species was not widespread. Dacrydium cupressinum type may too have grown within these forests, as it occasionally grows in flooded swamp forests (Wardle, 1974).

A high concentration of palm pollen (including Rhopalostylis sapida) was noted in these samples, indicating that palm trees were an important component within the region. The palms may have grown regionally as sub-canopy or over-story components within the surrounding forests, or locally in stands around the depositional site, or both (Enright \& Watson, 1992).

Another important component within the assemblage were tree ferns, as a moderate level of tree fern spores were recorded in both samples (Figure 3.3). These ferns may have grown either within the regional forests as a sub-canopy component or colonised along stream and river banks (Pocknall \& Turnbull, 1989).

Traces of pollen from Coprosma spp., Dracophyllum and Cassinia arcuata were recorded in KH1308a and KH1308b, as well as pollen from Malvaceae spp. These shrubby taxa may have grown as under-story components within the regional forests, with the cool temperate Coprosma spp. and Dracophyllum occupying areas at higher elevations (Wardle, 1991). Species of Malvaceae likely grew close to the depositional site, as pollen from this family is typically insect and animal dispersed (Franceschinelli, 2005; Abid et al., 2010).

Traces of pollen from Loranthaceae spp. and the climber Freycinetia were recovered from these samples. The presence of pollen from these plants suggests that woody climbers and shrubby mistletoes were present within the forested region, likely growing close to the depositional site. 
The local vegetation is largely represented by ground ferns and wetland herbs, as pollen from this vegetation tends not to travel large distances. The moderate concentration of ground fern spores suggests that ground ferns were fairly common around the depositional site.

Traces of pollen from the wetland herb Sparganium, a genus of the bur reed family (Kemp, 1976), indicates the presence of water saturated soils around the margins of the depositional site. This is supported by the presence of Rhoipites alveolatus pollen, a local swamp characteristic taxon of unknown natural affinity (Pocknall \& Turnbull, 1989).

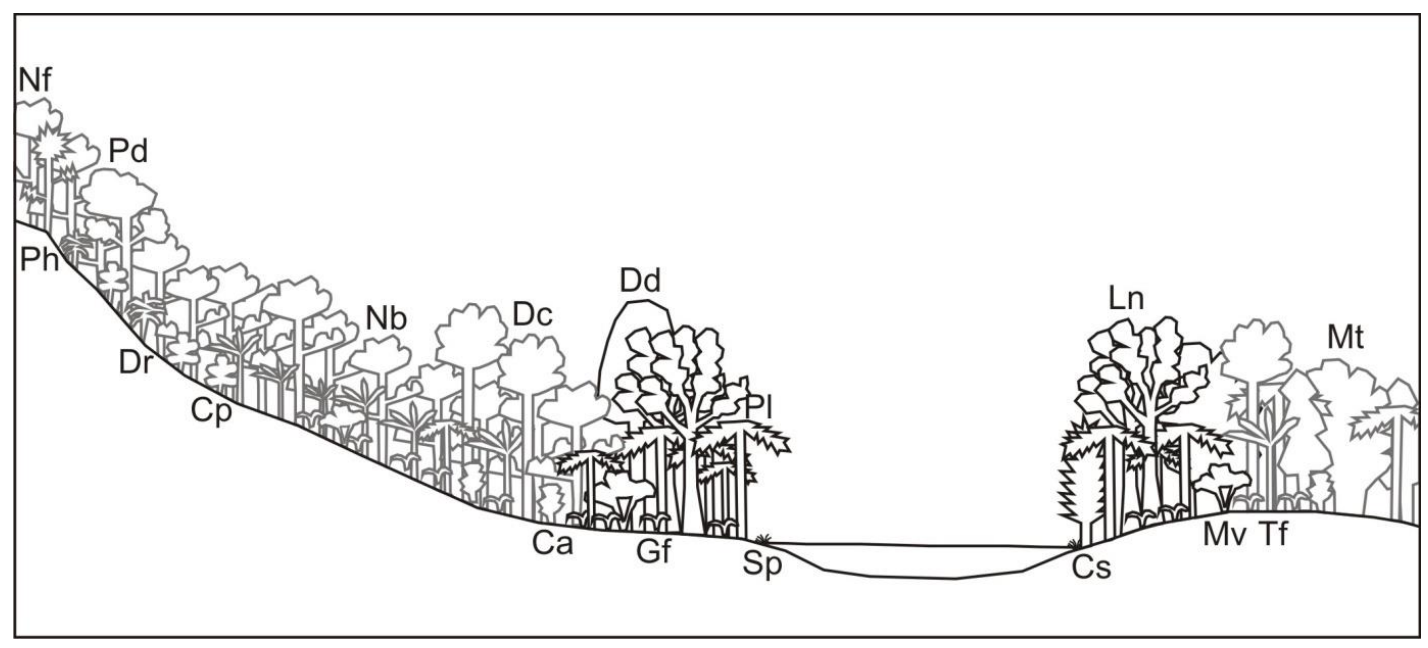

Figure 3.7: Schematic reconstruction of the Late Miocene vegetation from terrestrial mudstone in the Mangaoranga Stream area. The black outline represents local vegetation while the grey outline represents regional vegetation. $\mathrm{Nf}=$ Nothofagus fusca type beech; $\mathrm{Nb}=$ Nothofagus brassi type beech; $\mathrm{Pd}=$ Podocarpus $\mathrm{spp} . ; \mathrm{Ph}=$ Phyllocladus $\mathrm{spp} . ; \mathrm{Dc}$ = Dacrydium cupressinum type; $\mathrm{Dd}=$ Dacrycarpus dacrydioides $; \mathrm{Ln}=$ Laurelia novaezelandiae $; \mathrm{Mt}=$ Metrosideros spp.; $\mathrm{Cs}=$ Casuarinaceae spp.; $\mathrm{Pl}=$ palm trees; $\mathrm{Tf}=$ tree ferns; $\mathrm{Cp}=$ Coprosma spp.; $\mathrm{Dr}=$ Dracophyllum spp.; $\mathrm{Ca}=$ Cassinia arcuata $; \mathrm{Mv}=$ Malvaceae spp.; $\mathrm{Gf}=$ ground ferns and $\mathrm{Sp}=$ Sparganium .

\section{KH1312}

The flora recovered from terrestrial mudstone, collected immediately below a lignite horizon, is inferred to contain both regional and local taxa (Figure 2.3). This is due to the presence of mixed cool and warm temperate anemophilous vegetation (Nothofagus fusca type, Podocarpus spp., Nothofagus brassi type, palms and Casuarinaceae spp.), as well as the presence of taxa with low dispersal distances 
(Loranthaceae spp., Rhoipites, Sparganium and ground ferns). Figure 3.8 schematically illustrates the vegetation reconstruction for sample KH1312.

KH1312 contains abundant Casuarinaceae spp., Metrosideros spp. and palm pollen (including Rhopalostylis sapida). This vegetation is inferred to have grown in lowlying and coastal areas fairly close to the depositional site. The abundance of Metrosideros spp. pollen suggests that this genus may have been the dominant canopy component within lowland forests (Wilmshurst et al., 2004); while the high level of palm pollen indicates that these trees may have been an important subcanopy or over-story component within these forests. The palm trees may have also grown locally in stands around the depositional site (Enright \& Watson, 1992). Casuarinaceae spp. likely grew within the Metrosideros spp. forest, forming a coastal woodland forest. Some Casuarinaceae spp. may have also occupied areas along the forest margin close to the depositional site, as well as along stream and river sides (Pocknall, 1990).

Common sub-canopy components within the nearby forests include Coprosma spp. and tree ferns, which may have also colonised along nearby stream and river sides (Pocknall \& Turnbull, 1989; Wardle, 1991). Other possible sub-canopy components include Malvaceae spp., which were likely widespread.

Moderate to low levels of beech tree pollen (both Nothofagus fusca and Nothofagus brassi types) were recovered from KH1312 (Figure 3.4). The presence of both Nothofagus fusca and Nothofagus brassi types suggests that differences in elevation were present in the surrounding region during the time of deposition, supporting interpretations made in samples KH1308a and KH1308b. The beech trees may have formed the dominant canopy component within the surrounding regional forests, as in KH1308a and KH1308b.

Low levels of pollen from Dacrydium cupressinum type, Laurelia novaezelandiae and Proteaceae spp. were recorded in KH1312. These species likely occupied restricted areas within the low-lying regional forest, with Laurelia novaezelandiae occupying areas with saturated soils while Dacrydium cupressinum type occupied areas with better-drained soils (Dawson \& Sneddon, 1969; Norton et al., 1988). 
Traces of Podocarpus spp., Eucalyptus gummifera and mistletoe pollen were recorded in KH1312.The very low level of pollen from these taxa suggests that they were present but not dominant in the region. The mistletoe shrubs likely grew in forests close to the depositional site.

Local vegetation is represented by ground ferns and herbs, as in KH1308a and $\mathrm{KH} 1308 \mathrm{~b}$. A low level of ground fern spores were recorded in KH1312, indicating that ground ferns were present near the depositional site, possibly as the forest floor component within the surrounding forests (Mehltreter et al., 2010). Traces of the wetland herb Sparganium were also recovered from KH1312. This herb would have grown in shallow standing water along the margins of the depositional site (Sulman et al., 2013).

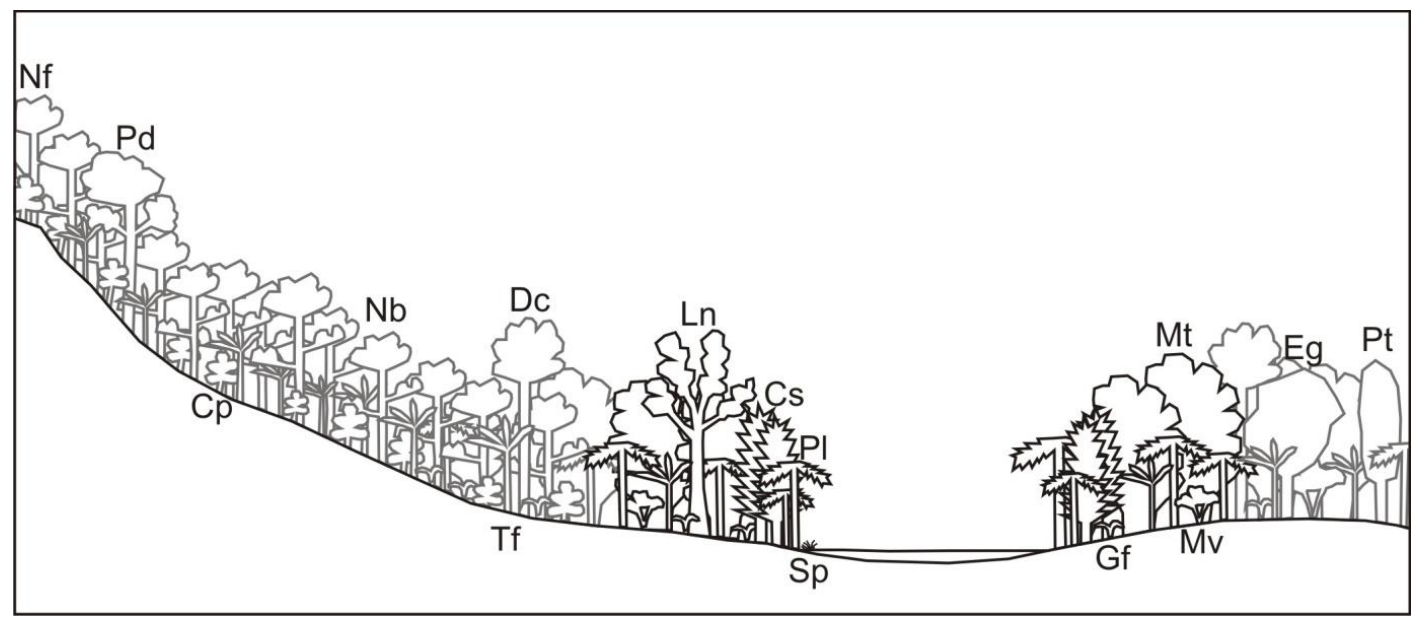

Figure 3.8: Schematic reconstruction of the Late Miocene vegetation from terrestrial mudstone in the Mangaoranga Stream area. The black outline represents local vegetation while the grey outline represents regional vegetation. $\mathrm{Nf}=$ Nothofagus fusca type beech; $\mathrm{Nb}=$ Nothofagus brassi type beech $\mathrm{Pd}=$ Podocarpus $\mathrm{spp} . ; \mathrm{Dc}=$ Dacrydium cupressinum type $; \mathrm{Ln}=$ Laurelia novaezelandiae $; \mathrm{Mt}=$ Metrosideros $\mathrm{spp} . ; \mathrm{Eg}=$ Eucalyptus gummifera $;$ $\mathrm{Pt}=$ Proteaceae spp.; $\mathrm{Cs}=$ Casuarinaceae spp.; $\mathrm{Pl}=$ palm trees; $\mathrm{Tf}=$ tree ferns; $\mathrm{Cp}=$ Coprosma spp.; $\mathrm{Mv}=$ Malvaceae spp.; $\mathrm{Gf}=$ ground ferns and $\mathrm{Sp}=$ Sparganium .

\section{KH1313}

The flora recovered from KH1313 is mostly local, as the sample was collected from a lignite horizon containing abundant swamp characteristic taxa (Figure 2.3). This is supported by the presence of swamp taxa with low dispersal distances (Rhoipites and Typha). Low levels of regional taxa are present in this sample, which are dominantly represented by Nothofagus fusca type beech trees. The assemblage recovered from 
KH1313 suggests that the environment was warm and wet (palms, Laurelia novaezelandiae, Typha, Metrosideros spp., Casuarinaceae spp. and Rhoipites pollen). A schematic reconstruction of the vegetation recovered from KH1312 is illustrated in Figure 3.9.

KH1313 contains a high concentration of palm (including Rhopalostylis sapida) and Coprosma spp. pollen. The abundance of palm pollen indicates that palm trees were common in the region. The palm trees may have formed stands close to the depositional site, or grown as sub-canopy or over-canopy components within nearby forests (Enright \& Watson, 1992). The high level of Coprosma spp. recovered suggests that these taxa were common in the region, possibly growing in marginal shrub zones close to depositional site or as a sub-canopy component within the surrounding forests (Wardle, 1991).

Moderate to low levels of pollen from Casuarinaceae spp. were recorded in KH1313. Species from this family are fairly common in similar aged lignite around New Zealand (the Gore Lignite Measures and the Central Otago lignites (Mildenhall, 1989; Pocknall \& Turnbull, 1989). These plants/trees may have grown close to the margins of the depositional site, possibly in the marginal shrub zone, and may have also occupied forests margins within the surrounding region.

Low levels of pollen from Laurelia novaezelandiae, Metrosideros spp. and Proteaceae spp. were recorded in KH1313. This vegetation was likely growing in lowland and coastal forests fairly close to the depositional site. Low levels of pollen from beech trees (Nothofagus fusca type) were also recorded in this sample. These trees were probably growing in forested areas at higher elevations in the region.

Tree and ground fern spores are fairly rare in KH1313. The tree ferns may have grown in the regional forests as sub-canopy components or along stream and river sides (Pocknall \& Turnbull, 1989), while the ground ferns grew close to the depositional site (Traverse, 1988).

Other taxa that grew close to the depositional site were Typha and vegetation associated with Rhoipites pollen. The low level of pollen from Typha suggests that 
this species would have grown in restricted areas around the margins of the depositional site, likely in pure stands as they commonly occur.

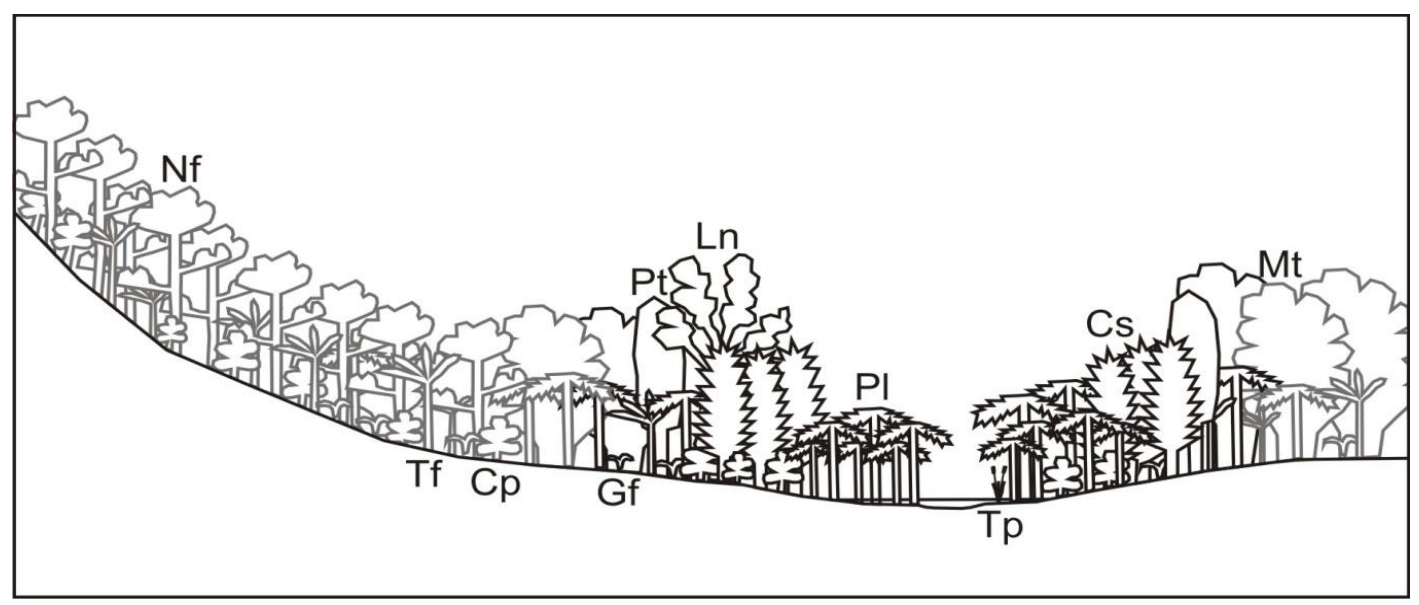

Figure 3.9: Schematic reconstruction of the Late Miocene vegetation from a lignite horizon in Mangaoranga Stream, Eketahuna. The black outline represents local vegetation while the grey outline represents regional vegetation. $\mathrm{Nf}=$ Nothofagus fusca type beech; $\mathrm{Ln}=$ Laurelia novaezelandiae $; \mathrm{Pt}=$ Proteaceae spp.; $\mathrm{Mt}=$ Metrosideros spp $; \mathrm{Cs}=$ Casuarinaceae spp.; $\mathrm{Pl}=$ palm trees; $\mathrm{Tf}=$ tree ferns; $\mathrm{Cp}=$ Coprosma $\mathrm{spp} . ; \mathrm{Gf}=$ ground ferns and $\mathrm{Tp}=$ Typha.

\section{KH1308c}

The pollen and spore assemblage of KH1308c, collected from a terrestrial mudstone bed directly above the lignite horizon (Figure 2.3), contains a high level of anemophilous pollen, such as pollen from beech and palm trees, Casuarinaceae spp. and Coprosma spp., as well as mixed warm and cool climate taxa (Nothofagus fusca and Nothofagus brassi type pollen). Due to the high level of anemophilous pollen recovered, much of the flora in this sample is inferred to represent regional vegetation. Local vegetation is inferred from pollen with low dispersal distances as well as vegetation from which fossil leaves were recovered within the mudstone matrix. A schematic reconstruction of the regional and local vegetation is illustrated in Figure 3.10. KH1308c also contains several species indicative of a wet environment (beech and palm trees, Laurelia novaezelandiae, Casuarinaceae spp., Typha and the pollen Rhoipites alveolatus).

KH1308c contains abundant beech tree pollen, from Nothofagus, Fuscospora and Nothofagus Brassospora subgenera (Figure 3.4). The presence of pollen from both subgenera indicates that differences in elevation were present during the time of 
deposition. As discussed in earlier samples, trees with Nothofagus fusca type pollen would likely have grown at higher elevations while trees with Nothofagus brassi type pollen grew in warmer low-lying areas.

Moderate to low levels of Metrosideros spp. and Laurelia novaezelandiae pollen were recovered from KH1308c. These taxa likely grew in lowland and coastal forests close to the depositional site as sub-dominant canopy and over-story components (Wilmshurst et al., 2004). Laurelia novaezelandiae pollen indicates that water saturated areas were present within the lowland forests, however the low levels of pollen indicate that these areas were likely limited in extent (Dawson \& Sneddon, 1969).

Moderate levels of pollen from Casuarinaceae spp. were recorded in KH1308c. Plants/trees from this family were likely widespread, growing within coastal woodland forests, as well as along forest margins and on stream and river banks (Pocknall, 1990). Also colonising on steam and river banks were tree ferns (Pocknall \& Turnbull, 1989), as a low level of tree ferns spores were recorded in KH1308c. These ferns may have also grown within the understory of regional forests.

Abundant sub-canopy components within the regional forests may have included Coprosma spp. and possibly palms, as a high level of pollen from these species was recorded (Wardle, 1991). The palms may have also grown in areas close to the coast as well as in stands close to the depositional site (Enright \& Watson, 1992).

Local vegetation occupying areas close to the depositional site include ground ferns, Typha and vegetation associated with Rhoipites alveolatus. Moderate levels of ground fern spores were recorded in KH1308c, indicating a common presence of ground ferns in local forests or open areas around the depositional site (Mehltreter et al., 2010). The presence of Rhoipites alveolatus indicates that water saturated soils were present near the depositional site.

The fossilised remains of leaves from up to three species of Lauraceae indicate that broad leaf taxa grew close to the depositional site. The remains of unidentified monocotyledon taxa also indicate a local presence near the depositional site. 
Traces of pollen from Astelia were present in KH1308c. Species from this genus, possibly from epiphyte plants, likely grew in frosted regions close to the depositional site, as these plants are entomophilous (Thomson, 1927).

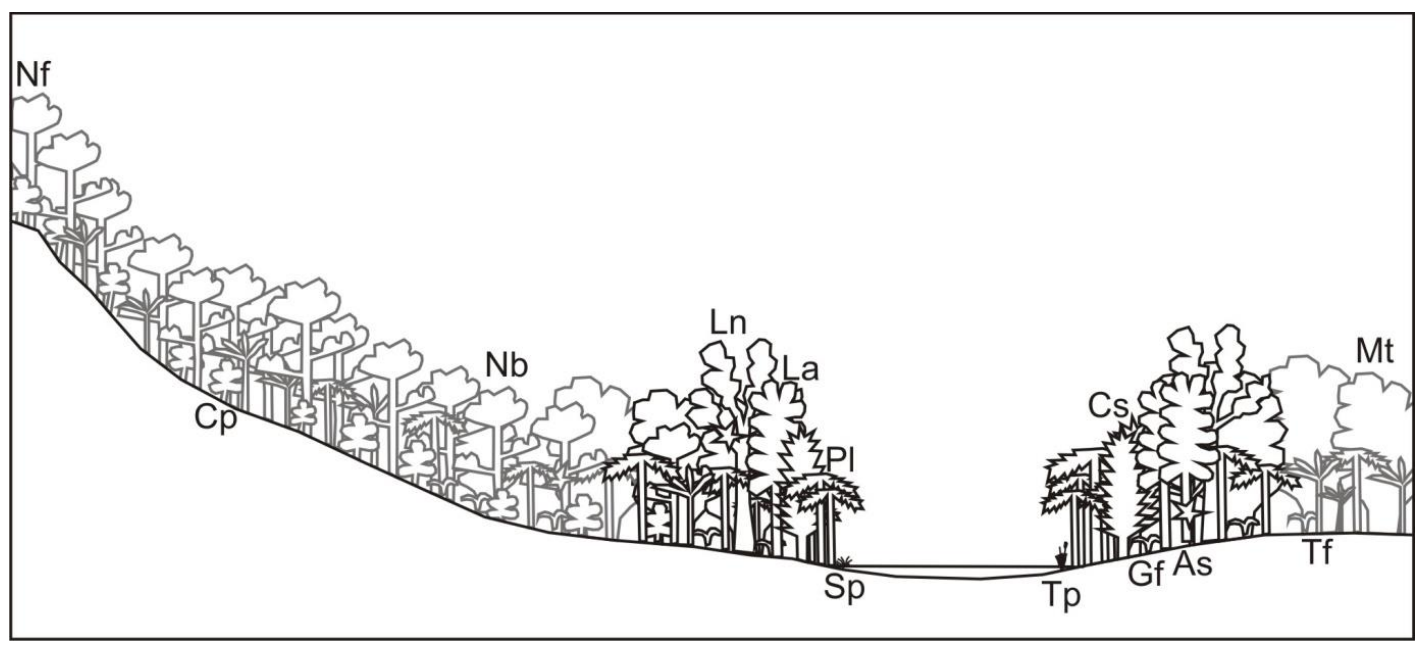

Figure 3.10: Schematic reconstruction of the Late Miocene vegetation from terrestrial mudstone in the Mangaoranga Stream area. The black outline represents local vegetation while the grey outline represents regional vegetation. $\mathrm{Nf}=$ Nothofagus fusca type beech; $\mathrm{Nb}=$ Nothofagus brassi type beech; $\mathrm{Ln}=$ Laurelia novaezelandiae $; \mathrm{La}=$ Lauraceae spp.; $\mathrm{Mt}=$ Metrosideros spp.; $\mathrm{Cs}=$ Casuarinaceae spp $; \mathrm{Pl}=$ palm trees; $\mathrm{Tf}=$ tree ferns $; \mathrm{Cp}=$ Coprosma spp.; $\mathrm{Gf}=$ ground ferns $; \mathrm{Tp}=$ Typha $; \mathrm{Sp}=$ Sparganium and As = Astelia .

\section{KH1314}

KH1314 was collected from marine mudstone, thus the flora recovered is regional (Figure 2.3). This is supported by the abundance of anemophilous taxa recovered, such as pollen from beech trees, Podocarpus spp., Dacrydium cupressinum type, Casuarinaceae spp. and Coprosma spp. The sample contains mixed warm and cool temperate taxa, as well as abundant species indicating a wet environment (beech trees, Rhopalostylis sapida, Laurelia novaezelandiae and Casuarinaceae spp.). Figure 3.11 schematically reconstructs the vegetation recovered from KH1314.

KH1314 contains a high level of beech pollen (both Nothofagus fusca and Nothofagus brassi types), indicating that beech forests were common in the region during the time of deposition (Figure 3.4). The presence of both Nothofagus fusca and Nothofagus brassi type pollen suggests that differences in elevation were present. This supports interpretations inferred in all other samples collected from the Mangaoranga Stream section. 
Moderate levels of pollen from Dacrydium cupressinum type and Metrosideros spp. were recorded in KH1314. These species were likely growing in warm temperate lowland and coastal areas (Norton et al., 1988; Wilmshurst et al., 2004). Low levels of Podocarpus spp. and Laurelia novaezelandiae pollen were also recorded. The cool temperate Podocarpus spp. may have grown in areas with higher relief, possibly as a sub-dominant canopy component within the Nothofagus fusca type forest, while Laurelia novaezelandiae grew in low-lying forests with saturated soils (Dawson \& Sneddon, 1969).

A high level of Coprosma spp. pollen was recorded in KH1314. This vegetation may have grown on open hilly areas at high elevations as extant ancestors commonly do (Raven, 1973), or grown as a dominant sub-canopy component within the regional forests (Wardle, 1991).

Low levels of pollen from palm trees (Rhopalostylis sapida) were recovered from KH1314. These trees would have grown on saturated soils as a sub-canopy or overstory component within the forested region, and possibly also grown along coastal areas (Enright \& Watson, 1992). Low levels of pollen from Casuarinaceae spp. were also recorded in KH1314. Plants/trees from this family likely fringed the forest margins in low-lying areas, possibly close to the coast and along stream and river banks (Pocknall, 1990)

Tree and ground fern spores are common in KH1314. These ferns likely grew within the forested region, with the tree ferns growing as dominant sub-canopy component or colonising along stream and river banks while the ground ferns grew on the forest floors (Pocknall \& Turnbull, 1989; Mehltreter et al., 2010).

A low level of Poaceae spp. pollen was recovered from KH1314. This suggests that grassland areas may have been present in the region.

Traces of pollen from Loranthaceae spp. and the climber Parsonsia straminea indicate that in forested regions, possibly close to the coast, shrubby mistletoes and woody climbers were present. 


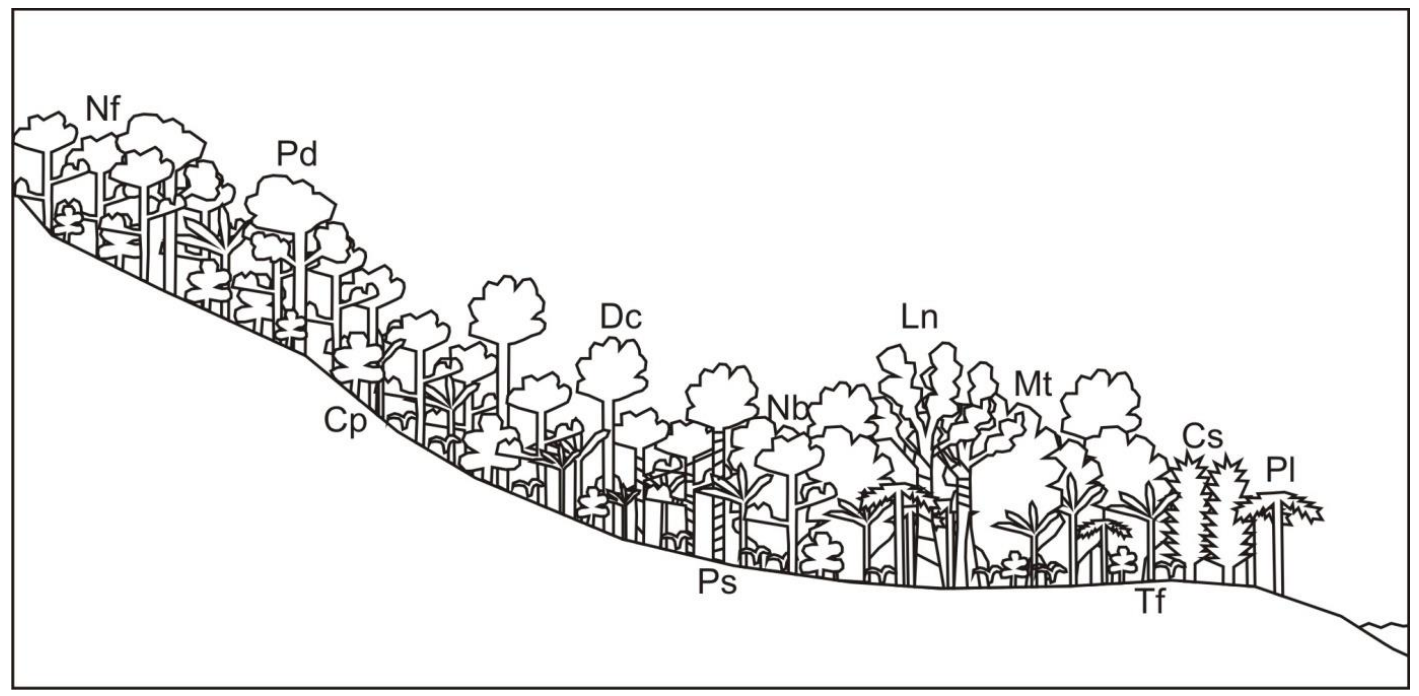

Figure 3.11: Schematic reconstruction of the Late Miocene regional vegetation in the Mangaoranga Stream area. Nf = Nothofagus fusca type beech; $\mathrm{Nb}=$ Nothofagus brassi type beech; $\mathrm{Pd}=$ Podocarpus $; \mathrm{Dc}=$ Dacrydium cupressinum type; $\mathrm{Ln}=$ Laurelia novaezelandiae $; \mathrm{Mt}=$ Metrosideros spp.; $\mathrm{Cs}=$ Casuarinaceae spp.; $\mathrm{Pl}=$ palm trees; $\mathrm{Tf}=$ tree ferns; $\mathrm{Cp}=$ Coprosma $\mathrm{spp}$. and $\mathrm{Ps}=$ Parsonsia straminea . 
Mauriceville section

KH1307

The flora recovered from terrestrial mudstone is inferred to be mostly regional as a high concentration of anemophilous taxa was recovered, such as Poaceae spp., beech, podocarps, and Coprosma spp. (Figure 2.11). The sample contains an unusually high concentration of cool climate indicators, such as beech trees with Nothofagus fusca type pollen, Podocarpus spp., Poaceae spp., Asteraceae spp. and Coprosma spp. The high concentration of cool climate taxa is inferred to represent a cool, dry interval in time. A reconstruction of the vegetation recovered from KH1307 is schematically illustrated in Figure 3.12.

Abundant Poaceae spp. pollen was recovered from KH1307 (Figure 3.3). The high level of pollen from this family indicates that widespread grassland areas were present in the region. Growing within these grasslands was Asteraceae spp., as pollen from both Taraxacum and Tubuliflorae spp. were recorded in this sample. The grassland areas likely grew over much the land surface, particularly in areas with higher elevation.

A low level of pollen from Coprosma spp. was recorded in KH1307. These species may have grown in open hilly areas, possibly in shrublands, or grown within the regional forests as a sub-canopy component (Wardle, 1991).

A low level of pollen from beech trees (Nothofagus fusca type), Dacrydium cupressinum type and Podocarpus spp. were also recorded in this sample. These trees were likely growing together in a mixed beech-podocarp-hardwood forest. The forest was likely confined to lowland areas in the region. The low level of pollen from these species suggests that the forest may not have been widespread, with much of the land areas occupied by grass and shrublands.

Growing within the mixed beech-podocarp-hardwood forest, and possibly also widespread, were tree ferns, as a high level of tree fern spores were recovered from KH1307. The presence of pollen from Parsonsia straminea, a forest tree climber pollinated by insects, indicates that the forest grew close to the depositional site (Turner \& Hawkeswood, 1996). 
Local vegetation includes grounds ferns and the vegetation associated with Rhoipites pollen. The presence of Rhoipites pollen suggest that swampy areas may have been present close to the depositional site, however the very low level of this pollen indicates that these areas were likely limited in extent. Moderate levels of ground fern spores were recorded in KH1307 which indicates that they were fairly common around the depositional site, possibly growing on surrounding forest floors or in slightly more open areas (Mehltreter et al., 2010).

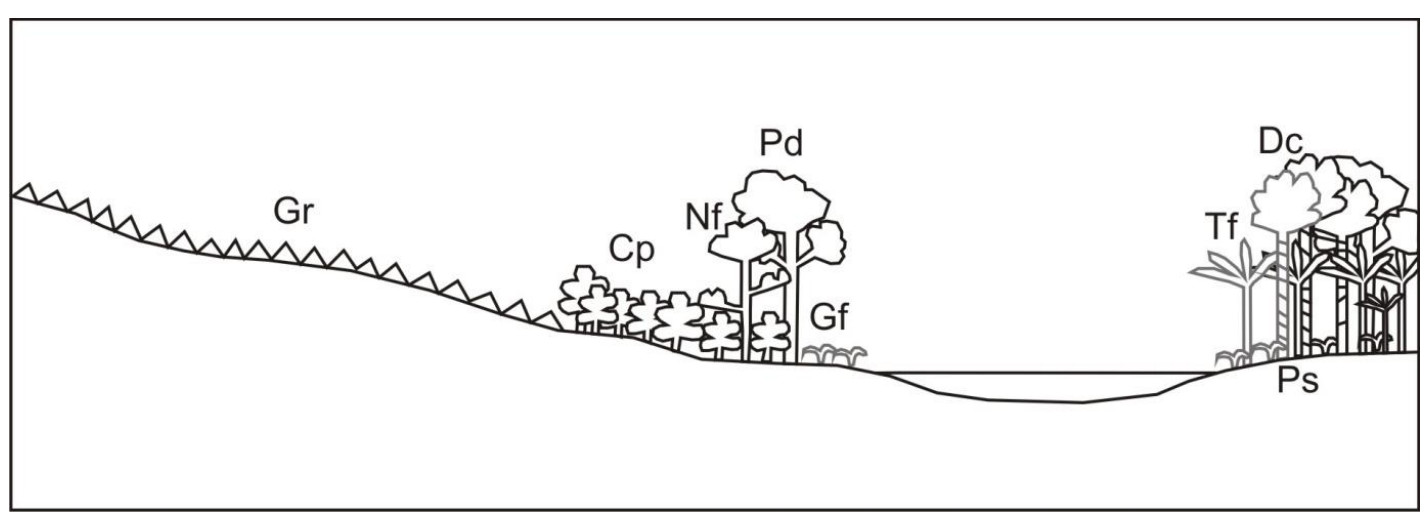

Figure 3.12: Schematic reconstruction of the Late Miocene vegetation from terrestrial mudstone in the Mauriceville area. The black outline represents local vegetation while the grey outline represents regional vegetation. $\mathrm{Nf}=$ Nothofagus fusca type beech; $\mathrm{Pd}=$ Podocarpus $; \mathrm{Dc}=$ Dacrydium cupressinum type; $\mathrm{Tf}=$ tree ferns; $\mathrm{Cp}=$ Coprosma $\mathrm{spp}$; $\mathrm{Gf}=$ ground ferns; $\mathrm{Gr}=$ Poaceae spp. and Ps = Parsonsia straminea .

\section{KH1306 and KH1309}

Samples KH1306 and KH1309 were collected from marine sediments, deposited in an off shore setting (Figure 2.11). Thus, the assemblage from these samples is clearly regional. This is supported by the high level of anemophilous pollen recovered, such as pollen from beech, Podocarpus spp., tree ferns, Dacrydium cupressinum type, Casuarinaceae spp. and palms. The vegetation recovered from these samples is schematically reconstructed in Figure 3.13.

The samples contain both warm (Nothofagus brassi type, Dacrydium cupressinum type and palm trees) and cool temperate climate indicators (Nothofagus fusca type, Podocarpus spp., Coprosma spp., Phyllocladus and Asteraceae spp.), suggesting that differences in elevation were present on land. The samples also contain many pollen types indicative of a wet climate (beech, Dacrydium cupressinum type, palm trees, Casuarinaceae spp., Laurelia novaezelandiae and Dacrycarpus dacrydioides). 
Moderate levels of beech pollen (Nothofagus fusca and Nothofagus brassi types) were recovered from KH1306 and KH1309 (Figure 3.4). The beech trees were likely growing in regional forests as the dominant canopy component, with Nothofagus fusca type growing at a slightly higher elevation to Nothofagus brassi type.

Within the lowland beech forests, Dacrydium cupressinum type and Laurelia novaezelandiae were common. Laurelia novaezelandiae would have grown in areas with saturated soils, likely in swampy areas within the forest, while Dacrydium cupressinum type grew in areas with moist, better-drained soils (Dawson \& Sneddon, 1969; Norton et al., 1988). Low levels of pollen from Dacrycarpus dacrydioides and palm trees were also recorded in these samples, supporting the presence of swampy/water saturated areas within the forest.

Traces of pollen from Proteaceae spp. and Metrosideros spp. were recorded in these samples. These taxa were likely growing in lowland areas, possibly close to coast, and may have been widespread (Yee \& Mitchell, 1991; Wilmshurst et al., 2004). Traces of pollen from Casuarinaceae spp. were also recorded in these samples. Vegetation from this family was likely growing along the forest margins, possibly close to the coast and in marginal shrub zones (Pocknall, 1990).

Within the cool temperate beech forests, Phyllocladus and Podocarpus spp. grew. The low level of pollen from these species suggests that they were present but not dominant components in the region.

Tree fern spores are abundant in KH1306 and KH1309. Thus, tree ferns were likely very common within the regional forests, possibly growing as a sub-canopy component, as well as colonising along stream and river sides (Pocknall \& Turnbull, 1989). Ground fern spores are also abundant in these samples. The ground ferns may have grown on the forests floor or in slightly more open areas (Mehltreter et al., 2010)

Traces of pollen from Asteraceae spp. and Poaceae spp. suggests the possible presence of open areas in the region. These open areas would likely have been located at cool temperate high elevations. Traces of pollen from Coprosma spp. were also recovered from these samples. These shrubs may have grown on open hilly areas 
at higher elevations, or grown as a sub-canopy component within the regional forests (Wardle, 1991).

Pollen from Parsonsia straminea was recovered from these samples, indicating the presence of woody climbers in the regional forests (Turner \& Hawkeswood, 1996).These plants were likely widespread in the regional forests.

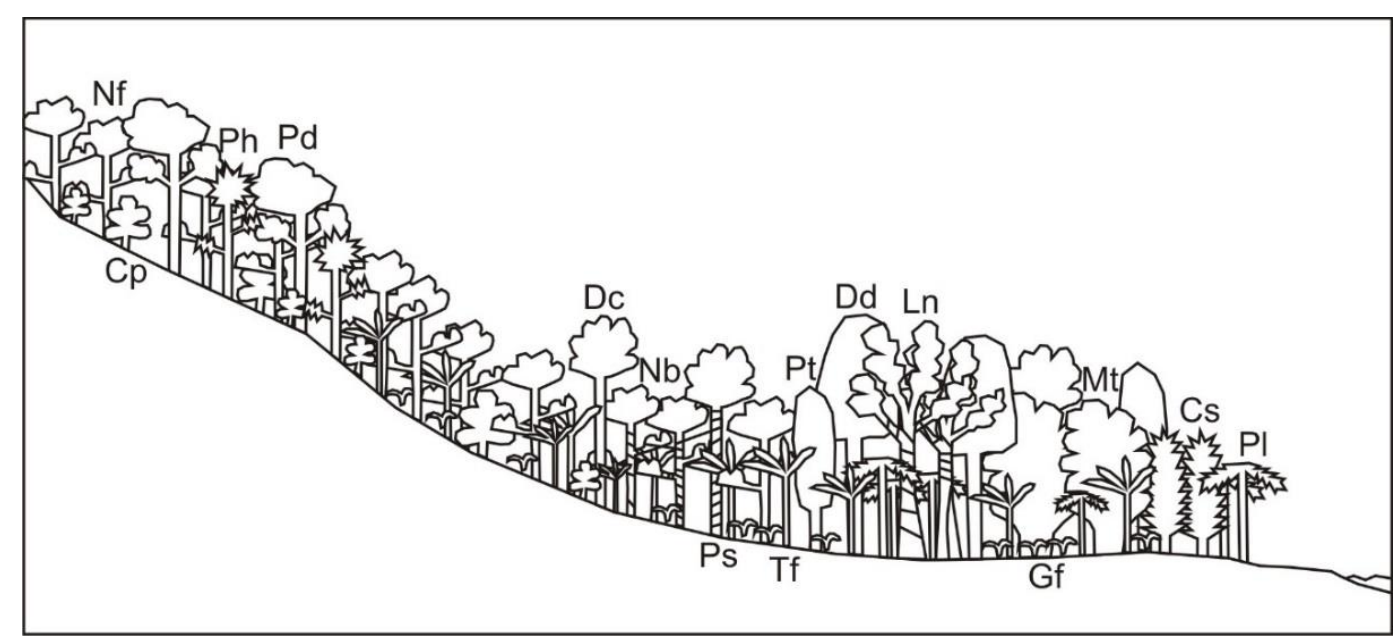

Figure 3.13: Schematic reconstruction of the Late Miocene regional vegetation in the Mauriceville area from marine mudstone. $\mathrm{Nf}=$ Nothofagus fusca type beech; $\mathrm{Nb}=$ Nothofagus brassi type beech; $\mathrm{Pd}=$ Podocarpus $; \mathrm{Ph}=$ Phyllocladus $; \mathrm{Dc}=$ Dacrydium cupressinum type; $\mathrm{Dd}=$ Dacrycarpus dacrydioides $; \mathrm{Ln}=$ Laurelia novaezelandiae $; \mathrm{Pt}=$ Proteaceae spp.; $\mathrm{Mt}=$ Metrosideros spp.; $\mathrm{Cs}=$ Casuarinaceae spp.; $\mathrm{Pl}=$ palm trees; $\mathrm{Tf}=$ tree ferns; $\mathrm{Cp}=$ Coprosma $\mathrm{spp} . ; \mathrm{Gf}=$ ground ferns and $\mathrm{Ps}=$ Parsonsia straminea . 


\section{Mt Bruce sample}

The flora from carbonaceous mudstone, sampled immediately below a lignite horizon, is largely local (Figure 2.15). This is inferred from the unusually high concentration of Bombax pollen recovered, as well as the presence of wetland taxa Typha, Polygonum amphibium, Cyperaceae spp. and Rhoipites. Figure 3.14 schematically illustrates the vegetation reconstruction for the Mt Bruce sample.

The sample contains both warm (Bombax, palms and wetland herbs) and cool temperate climate indicators (Nothofagus fusca type, Coprosma spp. and Phyllocladus), however is overwhelmed by warm temperate taxa. The presence of both warm and cool temperate taxa suggests that differences in elevation were present in the region during the time of deposition. The assemblage also contains abundant species from wet environments (Bombax, palm and beech trees, Typha, Polygonum amphibium and Cyperaceae spp.).

Moderate levels of beech pollen (Nothofagus fusca and Nothofagus brassi type flora) were recorded in this sample (Figure 3.4). The beech trees would have grown within the regional forests, with the cool temperate beech growing at higher elevations to the warm temperate beech, as inferred in earlier samples.

Species growing within the cool temperate beech forest may have included Phyllocladus and Coprosma spp. Low levels of pollen from these species were recorded in this sample, indicating that they may not have been widespread. Phyllocladus would likely have grown as a canopy component within the beech forest while the Coprosma spp. grew as a sub-canopy component. The Coprosma spp. may also have occupied areas of open shrubland (Wardle, 1991).

Sub-dominant canopy components within the lowland and coastal forests included Metrosideros spp., Proteaceae spp. and Agathis (Yee \& Mitchell, 1991; Wilmshurst et al., 2004). The low level of pollen recovered from this vegetation suggests that they were limited in extent.

Pollen from Bombax is very common in this sample. The Bombax would have grown close to the depositional site, as this vegetation is zoophilous and entomophilous (Raju et al., 2005). Also growing close to the depositional site, possibly among the 
Bombax, were palm trees, as abundant palm pollen was recovered from this sample. As well as growing close to the depositional site, the palm trees may have grown within regional forests as sub-canopy or over story components (Enright \& Watson, 1992).

Low levels of tree fern spores and pollen from Casuarinaceae spp. were recorded in this sample. The tree ferns would likely have grown within the forests and along stream and river banks while Casuarinaceae spp. flanked the forest margins in the region (Pocknall, 1990).

Growing around the margins of the depositional site in saturated soil or standing water were Typha, Cyperaceae spp., Polygonum amphibium, Haloragis and vegetation associated with Rhoipites pollen. Ground ferns would also have been common near the depositional site, occupying forest floors and open areas (Mehltreter et al., 2010).

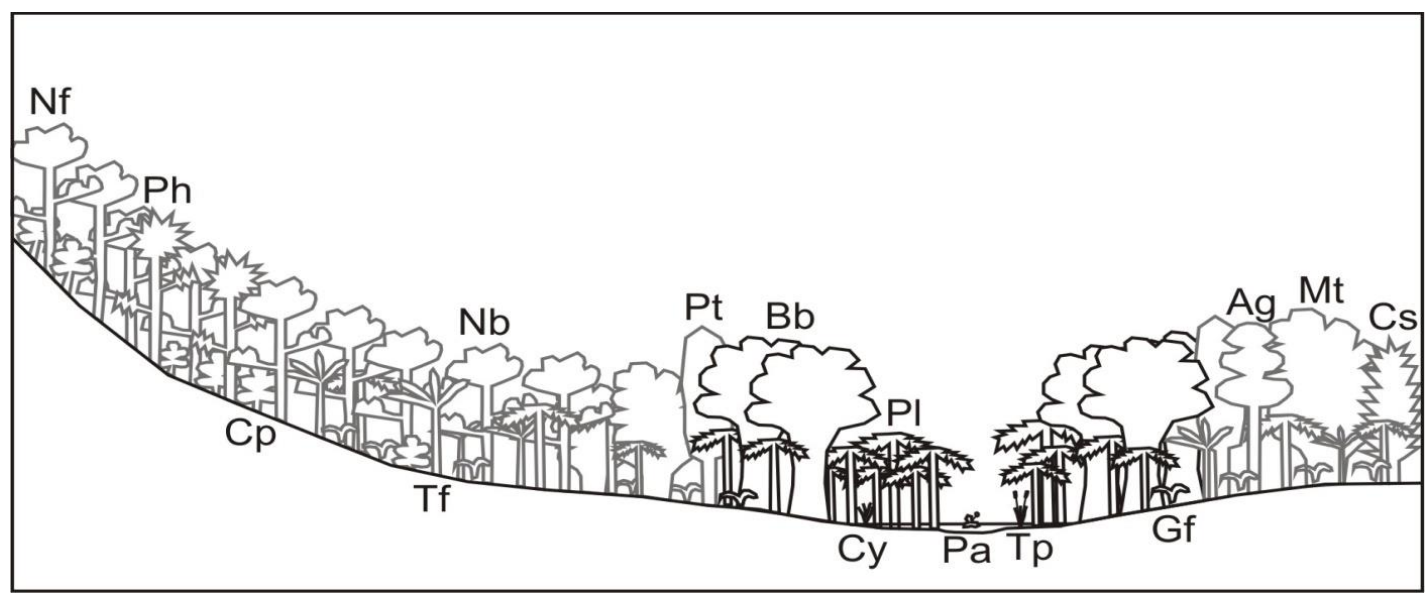

Figure 3.14: Schematic reconstruction of the Late Miocene vegetation in the Mt Bruce area, from carbonaceous mudstone. $\mathrm{Nf}=$ Nothofagus fusca type beech; $\mathrm{Nb}=$ Nothofagus brassi type beech $; \mathrm{Ph}=$ Phyllocladus spp.; $\mathrm{Pt}=$ Proteaceae spp.; $\mathrm{Bb}=$ Bombax $; \mathrm{Ag}=$ Agathis; $\mathrm{Mt}=$ Metrosideros spp.; $\mathrm{Cs}=$ Casuarinaceae spp.; $\mathrm{Pl}=$ palm trees; $\mathrm{Tf}=$ tree ferns; $\mathrm{Cp}=$ Coprosma spp.; $\mathrm{Gf}=$ ground ferns; $\mathrm{Cy}=$ Cyperaceae spp.; $\mathrm{Pa}=$ Polygonum amphibium and $\mathrm{Tp}=$ Typha. 


\subsubsection{Discussion summary}

Samples from the Mangaoranga Formation contain similar regional floral assemblages with differing local assemblages. The regional vegetation is typically represented by forests of beech and podocarp-hardwood flora. Common understory components within these forests include palm trees, tree ferns, and Coprosma spp. The local vegetation is often represented by wetland and swamp associated vegetation, such as Typha and Sparganium. Species with low dispersal distances, such as Bombax and Loranthaceae spp., are also inferred to represent local vegetation (although were likely widespread).

The samples contain both cool and warm temperate flora, indicating that differences in elevation were present in the Wairarapa region during the deposition of the Mangaoranga Formation. Since the mountains of the North Island are considered to be very young, forming in the last $2 \mathrm{Ma}$, it is unlikely that alpine habitats were present in the Wairarapa region during the Late Miocene (Ghani, 1978; Wells, 1989b; Heenan \& McGlone, 2012). However, there had to have been areas of considerable relief for the deposition of the $\mathrm{sm}_{1}$ (conglomerate) unit to occur. Thus, it is inferred that cool temperate areas of higher elevation, possibly a low-montane environment, were present in the Wairarapa region during the Late Miocene. The altitude of these areas is difficult to define, as much of the pollen identified in the present study comes from plants that are now extinct in New Zealand. In spite of this, an attempt to quantify the general altitudinal range is made based on the occurrence of contemporary cool temperate zones in the lower North Island. Wardle (1964) defined the cool temperate zone of the Tararua Range to occur between 416 - $915 \mathrm{~m}$ above sea level, with the warm temperate zone below this. Since temperatures were slightly warmer during the Late Miocene than at present (e.g. Shackleton \& Kennett, 1975), although still considered cool temperature (Mildenhall, 1980), the boundary of these zones may have been slightly higher. A modern analogy for the slightly warmer cool temperate montane environment are the mountains of the upper North Island, such as Te Moehau, Coromandel Peninsula (Gardner \& Dodsworth, 1984). Here, the climate is slightly warmer than in the lower North Island, but a cool temperate montane environment exists as the area reaches an altitude of 892 m above sea-level (Moore, 1973; Gardner \& Dodsworth, 1984). 
As well as being analogous to upper North Island low-montane habitats, the Late Miocene flora of north-west Wairarapa is also analogous to modern forests along the west coast of the North Island, New Zealand, and the upper west coast of the South Island (e.g. Karamea, West Coast of the upper South Island: Macphail \& McQueen, 1983). Here, forests contain mixed cool and warm temperate communities with common beech and podocarp-hardwood taxa, similarly to the assemblages recovered from this study.

The presence of mixed warm and cool temperate taxa is not uncommon in Miocene aged deposits around New Zealand, as samples from the Putangirua Conglomerate, southern Wairarapa, and Pareora Series, Canterbury, contain mixed warm and cool temperate climate indicators (McQueen et al., 1968). These mixed climatic assemblages may very well represent differences in elevation also. Similar floral assemblages to those recovered from the Mangaoranga Formation were also recovered from the Manuherikia Group (Miocene), Central Otago (Mildenhall, 1989; Mildenhall \& Pocknall, 1989). Common species that occur in both floral assemblages include beech, podocarps, Casuarinaceae spp., Myrtaceae spp. and Asteraceae spp.

Samples from the Mangaoranga Formation contain many species indicative of a wet environment, indicating that the climate was humid during much of deposition of the formation. A possible cool, dry interval is represented by the assemblage in KH1307. This time period saw a substantial reduction in forest cover and an increase in grasslands and shrublands. The cooling event that may be represented in this sample is the Late Miocene global-climatic cooling event (5.96-5.33 Ma), which led to the expansion of ice on Antarctica (Kennett, 1967; Hsü et al., 1977; Kennett, 1977; Ivanovic et al., 2013). Although this event occurred during the Kapitean stage, pollen from the carbonaceous shale below KH1307 indicates a Kapitean (possibly Tongaporutuan) age for the formation at this locality (Orbell, 1961). Thus, it is possible that the pollen assemblage in KH1307 represents the global-scale Late Miocene cooling event. 
Other explanations for the expansion of grasslands and shrublands include:

1. A widespread fire burning much of the forested region. This would result in the colonization of grasslands and shrublands (e.g. Timmins, 1992). Evidence of this in the stratigraphic record may include charred wood and ash.

2. A volcanic eruption leading to widespread ash cover. A thick cover of volcanic ash may have killed regional forests leading to the colonization of grasslands and shrublands (e.g. the 1886 Mt Tarawera Eruption: Clarkson, 1990). Evidence of such an event in the stratigraphic would include a volcanic ash layer.

3. Rapid localised uplift resulting in the exposure of new land. The new land may subsequently be colonised by grasslands and shrublands.

Although all three alternative explanations for the increase in grass and shrub pollen in $\mathrm{KH} 1307$ are possible, there is no evidence in stratigraphic record to suggest that any one of these events was the cause of the grass and shrubland colinisation.

\subsubsection{Fossil palynomorphs and age constraints}

The pollen and spores identified in this study were found to have a large age range, with all of the ages overlapping during the Neogene (23-2.6 Ma, Table 1). Thus, it is inferred that deposition of the Mangaoranga Formation occurred at some stage during this period. The abundance of cool temperate taxa, such as Nothofagus fusca type pollen, combined with the moderate level of shrub and herbaceous taxa recovered, suggests that deposition of the formation occurred during the Late Neogene $(11.6-2.6 \mathrm{Ma})$, when there was a notable increase in the amount of cool temperate taxa in New Zealand (Mildenhall, 1980). This is supported by the presence of Ligulifloridites sp., which first appeared in New Zealand during the Late Miocene.

The results of the pollen and spore analysis do not aid in refining the depositional age of the Mangaoranga Formation beyond Late Neogene. Thus, the age of Tongaporutuan $(11-7 \mathrm{Ma})$, as suggested in previous studies, remains the depositional age of the Mangaoranga Formation. 


\section{CHAPTER 4}

\section{Fission-track analysis}

\subsection{General introduction}

\subsubsection{Theory}

Fission-track (FT) analysis is a technique based on the spontaneous nuclear fission of ${ }^{238} \mathrm{U}$. This fission produces damage trails in the crystal lattice of uranium-bearing mineral grains (e.g. apatite, zircon and titanite) (Tagami \& O’Sullivan, 2005). Such spontaneous nuclear fission occurs in other heavy nuclides, however when considering the relative abundance and spontaneous fission half-lives, ${ }^{238} \mathrm{U}$ is the most significant source of spontaneous tracks in terrestrial rocks relative to the other naturally fissioning isotopes (such as ${ }^{232} \mathrm{Th}$ and ${ }^{235} \mathrm{U}$ ) (MacDougall, 1976).

The ${ }^{238} \mathrm{U}$ nucleus splits in half to form two similar-sized heavy nuclei masses. At the same time, several high-energy neutrons are emitted. During fission, the two nuclei masses recoil in opposite directions. When nuclear fission occurs in a nonconducting solid object, it leaves behind a microscopic damage trail in the crystal lattice known as a "fission track". For fission tracks to be observable under an optical microscope, they must first be chemically etched (MacDougall, 1976). The number of tracks in an individual mineral grain depends upon both the original uranium content and the amount of time spent below the closure temperature (Tagami \& O'Sullivan, 2005). The closure temperature for zircon and apatite ranges from 300 to $60^{\circ} \mathrm{C}$; hence the method is most usefully applied to determining the thermal histories of upper crustal sequences.

For apatite, the closure temperature is quoted as being approximately $110 \pm 10^{\circ} \mathrm{C}$ (e.g. Naeser, 1979; Gleadow et al., 1986). However, there is track instability over a broad transition zone known as the partial annealing zone (PAZ), from $120-60^{\circ} \mathrm{C}$ (Wagner \& Van den Haute, 1992). The annealing of fission tracks can be identified 
by measurement of the track lengths which is dependent on both the temperature and the extent of time exposed to that temperature (Gleadow et al., 1986).

For zircon, the annealing zone is less well known. The estimated transition zone ranges from $390-170^{\circ} \mathrm{C}$ (Yamada et al., 1995) with an approximate closure temperature of $240 \pm 30^{\circ} \mathrm{C}$ (e.g., Hurford 1986; Yamada et al., 1995; Brandon et al., 1998; Bernet et al., 2002).

In order to determine a fission-track age, the ${ }^{238} \mathrm{U}$ content must be determined. This is achieved by using the ${ }^{235} \mathrm{U}$ content in the material as a proxy for the ${ }^{238} \mathrm{U}$ content, as the ${ }^{235} \mathrm{U} /{ }^{238} \mathrm{U}$ ratio is constant in nature (MacDougall, 1976). The ${ }^{235} \mathrm{U}$ content is determined by attaching a uranium-free external detector to the prepared sample and bombarding it with neutrons. The bombardment induces fission of ${ }^{235} \mathrm{U}$ within the sample which is recorded in the external detector. The external detector is subsequently removed from the sample, etched in $40 \% \mathrm{HF}$ acid for 45 minutes at room temperature and the ${ }^{235} \mathrm{U}$ fission-track density per grain measured. The corresponding ${ }^{238} \mathrm{U}$ track density per grain is measured within the original sample. These measured densities are then used to calculate the time since the material passed through the closure temperature (Donelick et al., 2005).

The following formula proposed by Price \& Walker (1963) and Naeser (1967) is used to calculate the fission-track ages:

$$
t=\frac{1}{\lambda_{d}} \ln \left[1+\frac{\lambda_{d} \phi \sigma I}{\lambda_{f}} \frac{\rho_{s} g}{\rho_{i}}\right]
$$

where:

$\lambda_{d}=$ total decay constant for uranium $\left(1.55125 \times 10^{-10} \mathrm{y}^{-1}\right)$

$\lambda_{\mathrm{f}}=$ spontaneous fission decay constant for ${ }^{238} U$

$\mathrm{I}=$ isotope abundance ratio for ${ }^{235} U{ }^{238} U\left(7.2527 \times 10^{-3}\right)$

$\sigma=$ thermal neutron capture cross-section for ${ }^{235} U\left(580.2 \times 10^{-24} \mathrm{~cm}^{2}\right)$

$\phi=$ neutron fluence $\left(\mathrm{n} / \mathrm{cm}^{-2}\right)$

$\mathrm{g}=$ geometry correction factor 
$\rho_{\mathrm{s}}=$ spontaneous track density

$\rho_{\mathrm{i}}=$ induced track density

The values of $\lambda_{\mathrm{d}}$, I and $\sigma$ are constant and easily obtained while values $\rho_{\mathrm{s}}$ and $\rho_{\mathrm{i}}$ are determined by counting the number of tracks.

The neutron fluence is calculated by multiplying the induced track density in the glass/mica dosimeter by the constant calibration factor B. However, factor B is often difficult to determine. Thus, the neutron fluence is represented by $\rho_{\mathrm{d}}$ alone.

$$
\phi=B \rho_{d}
$$

The value of $\lambda_{\mathrm{f}}$ should be constant, however no value has yet been agreed upon. To account for this, a calibration factor is used to calculate fission track ages (Hurford $\&$ Green, 1983).The calibration factor, zeta, replaces factors $\lambda_{\mathrm{f}}, \sigma$ and I in equation 4.1:

$$
t=\frac{1}{\lambda_{d}} \ln \left[1+\lambda_{d} \zeta \frac{\rho_{s}}{\rho_{i}} g \rho_{d}\right]
$$

The zeta factor is calibrated by reference to independently characterised age standards.

\subsubsection{Aims}

Mesozoic greywackes, the Torlesse Supergroup, form the basement on which the Neogene sediments were deposited. The age of the oldest Neogene sediment on the greywacke represents the time at which the Mesozoic rocks had been brought to the surface since their original deposition and burial on the margins of Gondwana. The fission-track analysis was made in order to determine the tectonic history of the greywackes before they reached the surface in the Neogene. This provides a baseline structural setting for the study. 


\subsection{Sample collection and preparation}

Samples of medium to coarse grained greywacke were collected from the base of each of the Mangaoranga Stream, Mauriceville and Central Mangaone Road sites (Figure 2.3, Figure 2.11 and Figure 2.13, respectively). Each sample weighed approximately $5 \mathrm{~kg}$.

The basic processing technique is outlined below and follows standard fission-track processing techniques (e.g. Murakami \& Svojtka, 2007). A detailed explanation of this procedure is supplied in Appendix 2.1. Sample preparation was undertaken by Kirsten Henden while counting of both the apatite and zircon fission-tracks was undertaken by Prof Diane Seward.

The samples were crushed using the Boyd crusher and sieved with $250 \mu \mathrm{m}$ sieve cloth. The $<250 \mu \mathrm{m}$ material was passed across a Wilfley Table where the heavymineral fraction was collected. This was dried and then put through the Frantz isodynamic magnetic separator twice at 0.9 amps before the non-magnetic portion was placed in a heavy-liquid solution of methylene iodide $3.1 \mathrm{~g} / \mathrm{cm}^{3}$. The $>3.1 \mathrm{~g} / \mathrm{cm}^{3}$ portion was subsequently placed through methylene iodide $3.3 \mathrm{~g} / \mathrm{cm}^{3}$. The light fraction from this separation containing apatite crystals $\left(<3.3 \mathrm{~g} / \mathrm{cm}^{3}\right)$ was mounted onto circular glass mounts using epoxy resin. The heavy fraction containing zircon crystals (> $\left.3.3 \mathrm{~g} / \mathrm{cm}^{3}\right)$ was mounted into circular teflon sheets and subsequently onto round glass mounts with double-sided tape. Both the apatite-epoxy and zircon-teflon mounts were ground using wet sandpaper and polished on $3 \mu \mathrm{m}$ then $1 \mu \mathrm{m}$ diamond laps. The apatite mounts were etched for $20 \mathrm{~s}$ in a $21^{\circ} \mathrm{C}$ solution of $5.5 \mathrm{~N} \mathrm{HNO}_{3}$ while the zircon mounts were etched at $214 \pm 2^{\circ} \mathrm{C}$ in a $\mathrm{NaOH}-\mathrm{KOH}$ eutectic melt for 64 hrs. A low-uranium external detector (thin sheet of uranium free muscovite) was attached to both the zircon and apatite mounts, as well as several glass dosimeters (CN1 and CN5). The mounts were stacked into two separate plastic tubes with CN1 and CN5 between every eighth zircon and apatite mount respectively. The mounts were irradiated at the Radiation Center, Oregon State University, USA. Once returned, the external detectors were etched in $40 \% \mathrm{HF}$ acid for 45 minutes at room temperature. The fission tracks in both the mounts and thermal detectors were counted by Prof Diane Seward using a Zeiss Mm1 microscope. The zeta calibration method (Hurford \& Green, 1983) was used throughout. All ages are reported as 
central ages (Galbraith, 2005) with a 2 sigma error. Zeta zircon/CN1 was $120 \pm 5$ and apatite/CN5 was $355 \pm 5$. 


\subsection{Results and discussion}

The apatite yield was very low and the grains were sub-rounded, meaning that c axis crystals suitable for counting were few. However, it was possible to obtain 3 ages with large errors ranging from $25 \pm 8$ to $36 \pm 10 \mathrm{Ma}$ (Table 2). All ages overlap statistically at the 2 sigma level. These ages are younger than the sedimentary age of the greywackes and primarily support a post-depositional heating of the Mesozoic sequence to temperatures greater than $110^{\circ} \mathrm{C}$ during burial, followed by a cooling event at about 36 to $25 \mathrm{Ma}$ as the rocks were exhumed to the surface passing through the closure temperature of $110^{\circ} \mathrm{C}$. Unfortunately, there were insufficient track lengths for measurement. Hence no time-temperature modelling (e.g. Ketcham, 2005) was possible. The greywackes had cooled from $110^{\circ} \mathrm{C}$ to the surface $(10 \pm$ $10^{\circ} \mathrm{C}$ ) by approximately $11 \mathrm{Ma}$. A broad estimate of the cooling rate is then approximately $100^{\circ} \mathrm{C}$ in a minimum of $14 \mathrm{My}$ to a maximum of $25 \mathrm{My}$. Assuming a low geothermal gradient for the region of $<20^{\circ} \mathrm{C} / \mathrm{km}$ (Studt \& Thompson, 1969; Pandey, 1981) and a higher geothermal gradient of $25^{\circ} \mathrm{C} / \mathrm{km}$, this converts to exhumation rates of $0.36-0.20 \mathrm{~mm} / \mathrm{yr}$ and $0.28-0.16 \mathrm{~mm} / \mathrm{yr}$ respectively. Since the apatite fission-track age of the greywacke basement is older than the overlying sediments, it may be inferred that there was no later burial to the closure depth temperature since $11 \mathrm{Ma}$, i.e., the greywackes have not been reset since their exposure at $11 \mathrm{Ma}$. Since the lower temperature range for initiation of annealing is $60^{\circ} \mathrm{C}$ (Wagner \& Van den Haute, 1992), it can be inferred that the basement strata were not buried to depths where temperatures were $>60^{\circ} \mathrm{C}$. Implications for this are that the lower Neogene sediments have also not been buried more than $3 \mathrm{~km}$ (with a low geothermal gradient, $<20^{\circ} \mathrm{C} / \mathrm{km}$ ) or $2.4 \mathrm{~km}$ (with a higher geothermal gradient, $25^{\circ} \mathrm{C} / \mathrm{km}$ ). This then is a maximum sedimentary thickness of the overlying Neogene sediments. These values are greater than the thickness of the overlying Mangaoranga Formation (500 m) and immediately overlying Onoke Group (1200 m) (Neef, 1984). The measured sedimentary thicknesses do not take into account any material removed by erosion since the upper Pliocene.

The zircon central ages for KH1201 and KH1202 are $102 \pm 21$ and $172 \pm 32 \mathrm{Ma}$ respectively (Table 2). No zircons were recovered from KH1305. These zircon central ages lie within the stratigraphic age of the greywacke (175 - $100 \mathrm{Ma}$ : Lee \& 
Begg, 2002). Closer inspection of the single grain ages shows that the samples fail the chi square test at the $5 \%$ level implying that they are not a single population (Table 2). For sample KH1201, the age range is 61 to $206 \mathrm{Ma}$ (Appendix 2.2). Some grains are older than the sedimentary age, but others are younger. Similarly for sample KH1202, the age range is 99 to 289 Ma with the youngest age marginally younger than the supposed stratigraphic age (Appendix 2.2). It is concluded that the greywackes at these sites have been partially reset since deposition. Since the closure temperature for fission-tracks in zircons is $240 \pm 30^{\circ} \mathrm{C}$ (e.g. Hurford 1986; Yamada et al., 1995; Brandon et al., 1998; Bernet et al., 2002), it is concluded that the greywackes had reached approximately $200-250^{\circ} \mathrm{C}$ before being exhumed back to the surface by about 11 Ma.

Based on the apatite fission-track data sets, a schematic diagram of the thermal evolution of the basement strata was constructed (Figure 4.1). The zircon ages were not incorporated into this schematic diagram as events between 100 and 36 Ma were unknown.

In summary, the schematic diagram (Figure 4.1) shows that the basement strata sampled had cooled to about $110^{\circ} \mathrm{C}$ somewhere between 36 and $24 \mathrm{Ma}$, when fissiontracks were preserved. The strata then cooled further as they rose to the surface, where they were exposed between 11 and $7 \mathrm{Ma}$. At this time, the Mangaoranga Formation begun to be deposited on the exposed greywacke surface. The basement was then buried to depths no greater than $3-2.4 \mathrm{~km}$ and subsequently cooled to the surface where it is exposed today. 


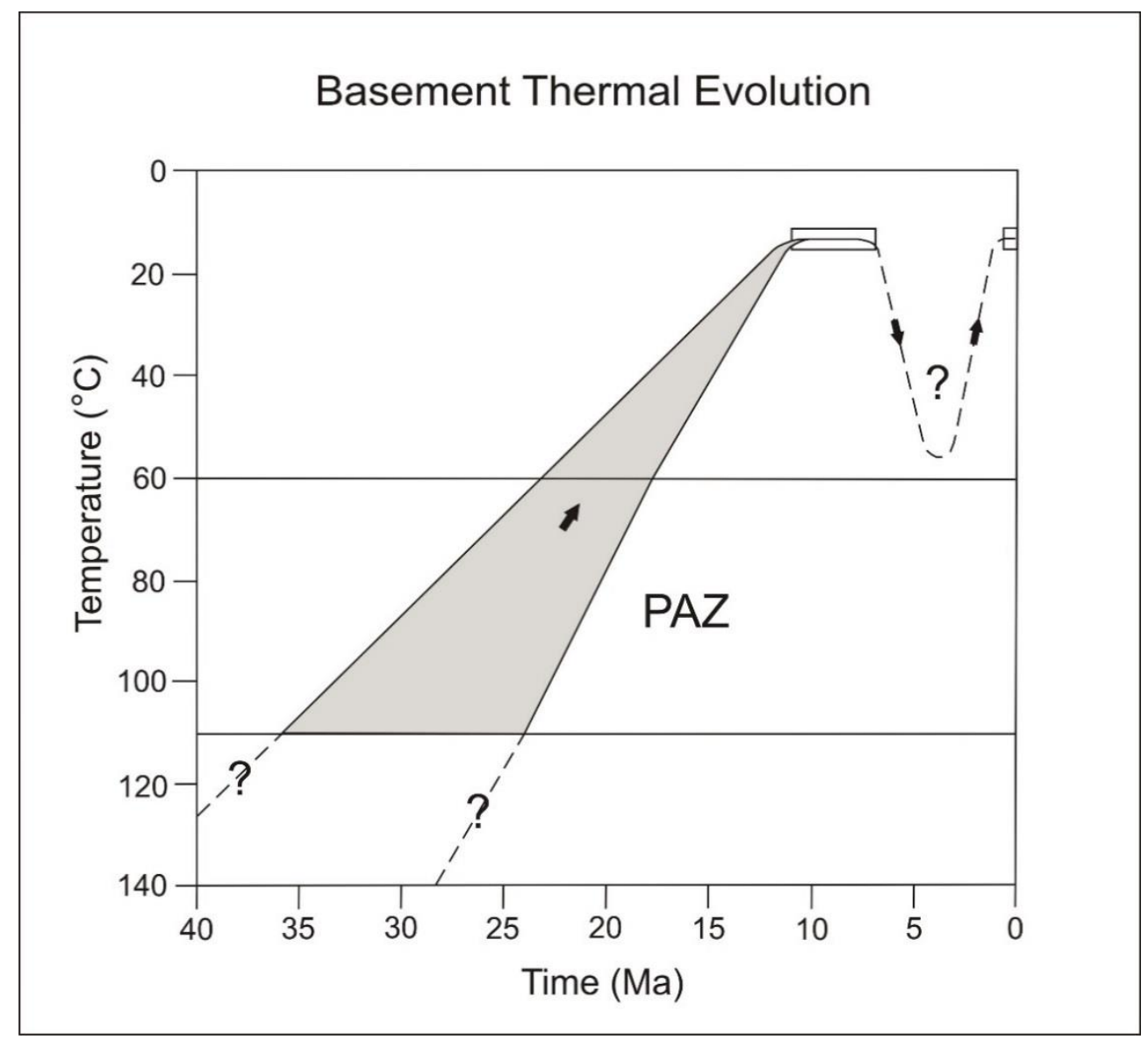

Figure 4.1: Schematic illustration of the thermal evolution of the basement strata based on fission-track and stratigraphic data. Shaded area $=$ the fission track age range of the samples; boxes $=$ time at which basement was at the surface; PAZ = apatite partial annealing zone $\left(110-60^{\circ} \mathrm{C}\right)$; arrows $=$ direction of basement cooling or heating and dashed lines $=$ unknown events. 


\begin{tabular}{|c|c|c|c|c|c|c|c|c|c|c|c|c|}
\hline $\begin{array}{l}\text { Sample } \\
\text { Number }\end{array}$ & Mineral & $\begin{array}{l}\text { Grid reference: } \\
\text { easting }\end{array}$ & $\begin{array}{l}\text { Grid reference: } \\
\text { northing }\end{array}$ & $\begin{array}{l}\text { Alt. } \\
\text { (m) }\end{array}$ & $\begin{array}{l}\text { Irradiation } \\
\text { number }\end{array}$ & $\begin{array}{l}\text { No. of } \\
\text { grains }\end{array}$ & $\begin{array}{l}\text { Standard track } \\
\text { density x } 10^{5} \\
\mathrm{~cm}^{-2} \text { (counted) }\end{array}$ & $\begin{array}{l}\rho_{\mathrm{S}} \times 10^{5} \mathrm{~cm}^{-2} \\
\text { (counted) }\end{array}$ & $\begin{array}{l}\rho_{\mathrm{i}} \times 10^{5} \mathrm{~cm}^{-2} \\
\text { (counted) }\end{array}$ & $\begin{array}{l}\text { U conc } \\
\text { ppm }\end{array}$ & $\begin{array}{l}\mathrm{P}\left(\chi^{2}\right) \% \\
\text { (dispersion) }\end{array}$ & $\begin{array}{l}\text { Central age } \\
\pm 2 \sigma(\mathrm{Ma})\end{array}$ \\
\hline KH1201 & Apatite & $175^{\circ} 43^{\prime} 48.26^{\prime \prime}$ & $40^{\circ} 40^{\prime} 28.31^{\prime \prime}$ & 290 & VUW011-25 & 19 & $11.53(2350)$ & $2.10(95)$ & $13.01(588)$ & 15 & $6(0.3)$ & $36.0 \pm 10.2$ \\
\hline KH1201 & Zircon & $175^{\circ} 43^{\prime} 48.26^{\prime \prime}$ & $40^{\circ} 40^{\prime} 28.31^{\prime \prime}$ & 290 & VUW012-2 & 11 & $5.60(2234)$ & $86.89(1425)$ & $29.70(102)$ & 167 & 0 & $102 \pm 21$ \\
\hline KH1202 & Apatite & $175^{\circ} 45^{\prime} 47.73^{\prime \prime}$ & $40^{\circ} 37^{\prime} 28.00^{\prime \prime}$ & 203 & VUW011-24 & 9 & $11.60(2350)$ & $0.52(20)$ & $4.16(161)$ & 5 & $95(0)$ & $25.2 \pm 12.2$ \\
\hline KH1202 & Zircon & $175^{\circ} 45^{\prime} 47.73^{\prime \prime}$ & $40^{\circ} 37^{\prime} 28.00^{\prime \prime}$ & 203 & VUW012-4 & 10 & $5.67(2234)$ & $58.96(1592)$ & $11.52(311)$ & 99 & $4(0.2)$ & $172 \pm 32$ \\
\hline KH1305 & Apatite & $175^{\circ} 42^{\prime} 27.33^{\prime \prime}$ & $40^{\circ} 45^{\prime} 44.52^{\prime \prime}$ & 226 & VUW015-18 & 9 & $12.23(2424)$ & $5.172(60)$ & $45.52(528)$ & 49 & $17(0.02)$ & $25.4 \pm 8.4$ \\
\hline
\end{tabular}

Table 2: Apatite and zircon fission-track ages from Wairarapa greywacke outcrops. All ages are central ages (Galbraith, 2005). $\rho_{\mathrm{S}}$ and $\rho_{\mathrm{i}}$ represent sample spontaneous and induced track densities; $\mathrm{P}\left(\chi^{2}\right)$ is the probability of $\chi^{2}$ for $\mathrm{v}$ degrees of freedom where $\mathrm{v}=$ no. of crystals $-1 ; \lambda \mathrm{D}=1.55125 \times 10^{-10}$. $\zeta \mathrm{CN} 5 /$ apatite $=$ $355 \pm 5, \zeta \mathrm{CN} 1 /$ zircon $=120 \pm 5$. Samples were irradiated at the Oregon State University Reactor Facility. 


\section{CHAPTER 5}

\section{Geological evolution}

\subsection{Summary of the Permian to Miocene geological evolution of Wairarapa}

\subsubsection{Permian - Early Cretaceous}

The Torlesse Supergroup, consisting predominantly of quartzofeldspathic sandstone and argillite with minor components of basalt, conglomerate, chert, coloured argillite and limestone, was deposited at an ancient convergent margin off the eastern coast of Gondwanaland (Adams \& Graham, 1996; Graham, 2008). The rare occurrence of fossils places deposition of the supergroup from the Permian to Early Cretaceous (Bradshaw, 1973; Andrews et al., 1976; Speden, 1976; Aita \& Spörli, 1992; Adams et al., 1999). Following deposition, the sediments of the supergroup were lithified, undergoing low-grade metamorphism (Coombs \& Cox, 1991).

Today, the rocks of the supergroup make up the Eastern Province basement strata of New Zealand (Landis \& Coombs, 1967; Carter et al., 1978). These rocks were divided in tectonostratigraphic terranes (Coombs et al., 1976), and further subdivided into units based on age, petrology, geochemistry and isotope geochemistry (e.g. Bradshaw et al., 1981; Roser et al., 1995). At the sections examined in the present study, the basement strata are composed of the Middle Jurassic to Early Cretaceous Waioeka terrane.

\subsubsection{Early Cretaceous - Oligocene}

At about $85 \mathrm{Ma}$, a rift zone formed that initiated the separation of New Zealand from Gondwana, leading to New Zealand occupying a passive margin setting until the Early Miocene (Ballance, 1993). Over this period, thermal relaxation led to the submergence of most of New Zealand by the Late Oligocene (Ballance, 1993). This 
submergence subsequently resulted in the widespread deposition of a marine transgressional sequence over much of the New Zealand subcontinent.

Today in the central and eastern Wairarapa areas, late Early Cretaceous to Oligocene rocks are preserved in the stratigraphic record, but rocks of this period are absent from western Wairarapa. The late Early Cretaceous to Oligocene rocks are dominated by fine-grained marine sandstones and mudstones which unconformably overlie Early Cretaceous basement rocks (Figure 2.1). The preservation of these marine rocks implies that the central and eastern areas of the Wairarapa region were submerged from the latest Early Cretaceous until the Late Oligocene.

Sedimentation of these rocks initially occurred in a marine shelf or bathyal environment (Moore \& Morgans, 1987; Crampton, 1997; Field et al., 1997; Killops et al., 2000). This deepened to a mid to upper bathyal environment by the Oligocene.

\subsubsection{Miocene}

The change from New Zealand occupying a passive margin setting to that of an active convergent margin occurred during the Early Miocene (King et al., 1999). It is suggested that the formation of a rift zone between Australia and Antarctica during the Late Oligocene, the migration of the Pacific/Australian Euler pole and the spreading of the Emerald Basin led to the renewed convergence of the Australian and Pacific plates (e.g. Walcott, 1984; King, 2000). This convergence resulted in the initiation of the Kaikoura Orogeny (King et al., 1999).

In the Wairarapa region, convergence between the Australian and Pacific plates resulted in the deformation of Oligocene and older sequences. These sequences were compressed into small, elongate and sub-parallel basins with migrating depocentres (Lewis, 1980; Wells, 1989b). The basins were infilled with Miocene and younger sediments. Turbidite sedimentation was common during the Early and Late Miocene (Spörli, 1980; Van der Lingen \& Pettinga, 1980).

\section{Early Miocene}

The change from a passive margin setting to that of an active convergent margin is recognised in the stratigraphic record in central and eastern Wairarapa primarily by 
a widespread unconformity at the base of the Palliser Group (Vella \& Briggs, 1971; Johnston, 1980; Reid, 1998). Here, Early Miocene sandstone-dominated deposits of the lower Palliser Group overlie Eocene and Oligocene mudstone-dominated deposits (Figure 2.1). In areas where the transition is conformable in the stratigraphic record, such as at Takiritini Stream near Te Mai, eastern Wairarapa, it is recognised by a gradual change to clastic sedimentation (e.g. Johnston, 1980).

The resulting Early Miocene sequences were deposited in an inner shelf environment during an abrupt marine regression (Johnston, 1980; Lee \& Begg, 2002). Early Miocene sequences are absent in western Wairarapa.

\section{Middle-Late Miocene}

The Early Miocene period of uplift, erosion and regression was short lived. By late Early Miocene, the central and eastern Wairarapa areas had begun to subside resulting in the deposition of a largely transgressional sequence which continued through to the Pliocene. Deposition of the transgressional sequence may have resulted from an increase in compressional faulting due to an increase in the rate of rotation of the Pacific/Australian Euler Pole since the mid-Early Miocene (Walcott, 1984). Much of this increase in rotation occurred following the Middle Miocene, when a marked change in the position of the Euler pole occurred (Walcott, 1984).

In the central and eastern Wairarapa areas, Middle to Late Miocene mudstonedominated rocks of the Palliser Group rest conformably on Early Miocene sequences or unconformably on older rocks (Figure 2.1). Sedimentation of these rocks occurred in a basin that overall was gradually subsiding to mid-upper bathyal water depths (e.g. Beu, 1970; Vella \& Briggs, 1971). Rocks of mid Miocene age are absent from the stratigraphic record in western Wairarapa. 


\subsection{Upper Miocene geological evolution of north-western Wairarapa}

\subsubsection{Overview}

In contrast to the central and eastern Wairarapa areas, there is a major unconformity in western Wairarapa between greywacke basement and the overlying Neogene sediments. In north-west Wairarapa, rare outcrops of Late Miocene sequences are preserved unconformably overlying Middle Jurassic to Early Cretaceous basement rocks (Figure 2.1). These Late Miocene sequences consist of terrestrial and marine deposits placed in the Soren Group by Neef (1984) and divided into the Mangaoranga and Kaiparoro formations.

Deposition of these formations occurred in a subsiding forearc basin (the Mt Bowens Basin: Neef, 1999; Wells, 1989b). A shallow seismic reflection survey in the Eketahuna region shows a suite of northeast-trending westward-dipping strike-slip and reverse faults cutting part of this basin (Lamarche et al., 1995). These faults can be seen deforming the greywacke basement and overlying Neogene sediments, tilting blocks to the north-west. Lamarche et al. (1995) concluded that movement along these faults occurred contemporaneously with deposition of the Neogene sediments. Thus, the accumulation of the deposits of the Mangaoranga and Kaiparoro formations was at least, in part, syn-depositional with the tectonic activity.

\subsubsection{Basement burial and exhumation}

The large hiatus in the stratigraphic record between deposition of the greywacke basement and overlying Neogene sediments, with no remaining record of Middle Cretaceous to Middle Miocene sediments, has allowed only a limited understanding of the evolution of north-western Wairarapa. However, apatite fission-track analysis on greywacke basement immediately below the Mangaoranga Formation made as part of the present study enables the exhumation history of the basement strata during part of this hiatus to be reconstructed.

Apatite fission-track ages for the greywacke basement at the three sites examined in this study (Figure 1.2) range from $25 \pm 8$ to $36 \pm 10 \mathrm{Ma}$ (2 sigma error, Table 2). This suggests that the greywacke basement had cooled to $\sim 110^{\circ} \mathrm{C}$ between 36 and 25 
$\mathrm{Ma}$ at each site. If geothermal gradients of $20{ }^{\circ} \mathrm{C} / \mathrm{km}$ and $25{ }^{\circ} \mathrm{C} / \mathrm{km}$ for western Wairarapa are used (Studt \& Thompson, 1969; Pandey, 1981), and a surface paleotemperature of $\sim 10^{\circ} \mathrm{C} \pm 10^{\circ} \mathrm{C}$, this implies the greywacke was at a depth of about $5 \mathrm{~km}$ and $4 \mathrm{~km}$ respectively.

Cooling of the greywackes as a result of uplift and erosion subsequently occurred, leading to their surface exposure between 11 and $7 \mathrm{Ma}$ (Figure 4.1). Cooling of the greywackes over this period implies exhumation rates of $0.36-0.20 \mathrm{~mm} / \mathrm{yr}$ and 0.28 $-0.16 \mathrm{~mm} / \mathrm{yr}$ respectively. These rates of exhumation are relatively fast but compare well to fission-track estimates for the rate of exhumation of the southern Wellington area since $10 \mathrm{Ma}(0.4 \mathrm{~mm} / \mathrm{yr}$ : J. Ruohong, personal communication, January 30, 2014).

At some time between 11 and 7 Ma subsidence in north-west Wairarapa resulted in the development of accommodation space which in turn allowed for the accumulation of the deposits of the Mangaoranga Formation. Renewed burial of the greywacke basement occurred as part of this process. However, since the apatite fission-track ages for the greywacke $(36-25 \mathrm{Ma})$ are older than the stratigraphic age of the Mangaoranga Formation (11-7 Ma), it appears that the apatite fission-tracks were not reset. This implies that the basement rocks and implicitly their overlying Neogene sediments were not buried to depths with temperatures $>60^{\circ} \mathrm{C}$, or more than about $3 \mathrm{~km}$ (with a geothermal gradient of $20{ }^{\circ} \mathrm{C} / \mathrm{km}$ ) or $2.4 \mathrm{~km}$ (with a geothermal gradient of $25^{\circ} \mathrm{C} / \mathrm{km}$ ). Burial of the greywacke surface to less than $3-$ $2.4 \mathrm{~km}$ is supported by the total thickness of Miocene and younger sediments east of the Alfredton fault, suggested to be about $1700 \mathrm{~m}$ (Neef, 1984).

Following burial of the greywacke and sedimentation of the overburden, the basement strata subsequently cooled again as they were uplifted to the surface where they are exposed today (Figure 4.1).

\subsubsection{Tongaporutuan sedimentation (Mangaoranga Formation)}

The earliest sedimentation in north-western Wairarapa following the first known uplift of the greywacke basement was of greywacke conglomerate $\left(\mathrm{sm}_{1}\right)$. The 
conglomerate was deposited by northward-flowing braided rivers, implying that a source of uplifted greywacke was located to the south (Figure 5.1). The rounding of the clasts implies that deposition occurred some distance from this source. As Lamarche et al. (1995) suggested, deposition of this conglomerate occurred contemporaneously with tectonic activity, resulting in the sedimentation of the conglomerate in half-grabens.

At the Mangaoranga Stream and Mauriceville sites, the probable development of north-south trending reverse faults to both the east and west of the sites resulted in the formation of a north-south trending depression. This depression subsequently filled with water, leading to the formation of a large lake (Figure 5.1). The lake persisted for perhaps $95 \mathrm{ky}$, leading to the sedimentation of up to $95 \mathrm{~m}$ of mud, sand and organic matter (at an average sedimentation rate of $1 \mathrm{~m} / \mathrm{ky}$ by analogy with lakes in similar tectonic settings).

Eventually, the lake shallowed as a result of tectonic activity and/or a decrease in accommodation space. This led to rivers flowing back over the area and the continued deposition of $\mathrm{sm}_{1}$ conglomerate.

Subsidence of the basin eventually led to the drowning of areas of north-west Wairarapa and the subsequent sedimentation of a marine transgressive sequence (Figure 5.1). First, shallow marine sandstone $\left(\mathrm{sm}_{3}\right)$ was deposited, followed by siltstone $\left(\mathrm{sm}_{4}\right)$ and mudstone $\left(\mathrm{sm}_{5}\right)$ respectively. Analyses of microfaunas throughout this transgressive sequence at the Mangaoranga Stream site suggest that water depths reached a maximum of $600 \pm 300$ m (Kennett, 1966), implying an average rate of basin subsidence of $0.28 \mathrm{~mm} / \mathrm{yr}$.

The transgression likely progressed from the east and/or north of the sites, reaching the Mauriceville, Mangaoranga Stream and Central Mangaone Road sites first. At Mt Bruce, the transgression initially resulted in the development of an estuary, where mudstone (Moles Mudstone, $\mathrm{sm}_{0}$ ) accumulated above greywacke basement. Rapid erosion of the surrounding relief resulted in the development of an alluvial fan over this estuary (Figure 5.1). This led to the sedimentation of conglomerate $\left(\mathrm{sm}_{1}\right)$. Continued basin subsidence eventually resulted in the sedimentation of the upper Mangaoranga Formation marine transgressive sequence $\left(\mathrm{sm}_{3}, \mathrm{sm}_{4}\right.$ and $\mathrm{sm}_{5}$ 
respectively). Foraminifera in the mudstone member indicate that, by the Late Tongaporutuan, water depths in the Mt Bruce area had reached $300 \mathrm{~m}$ (Wells, 1985).

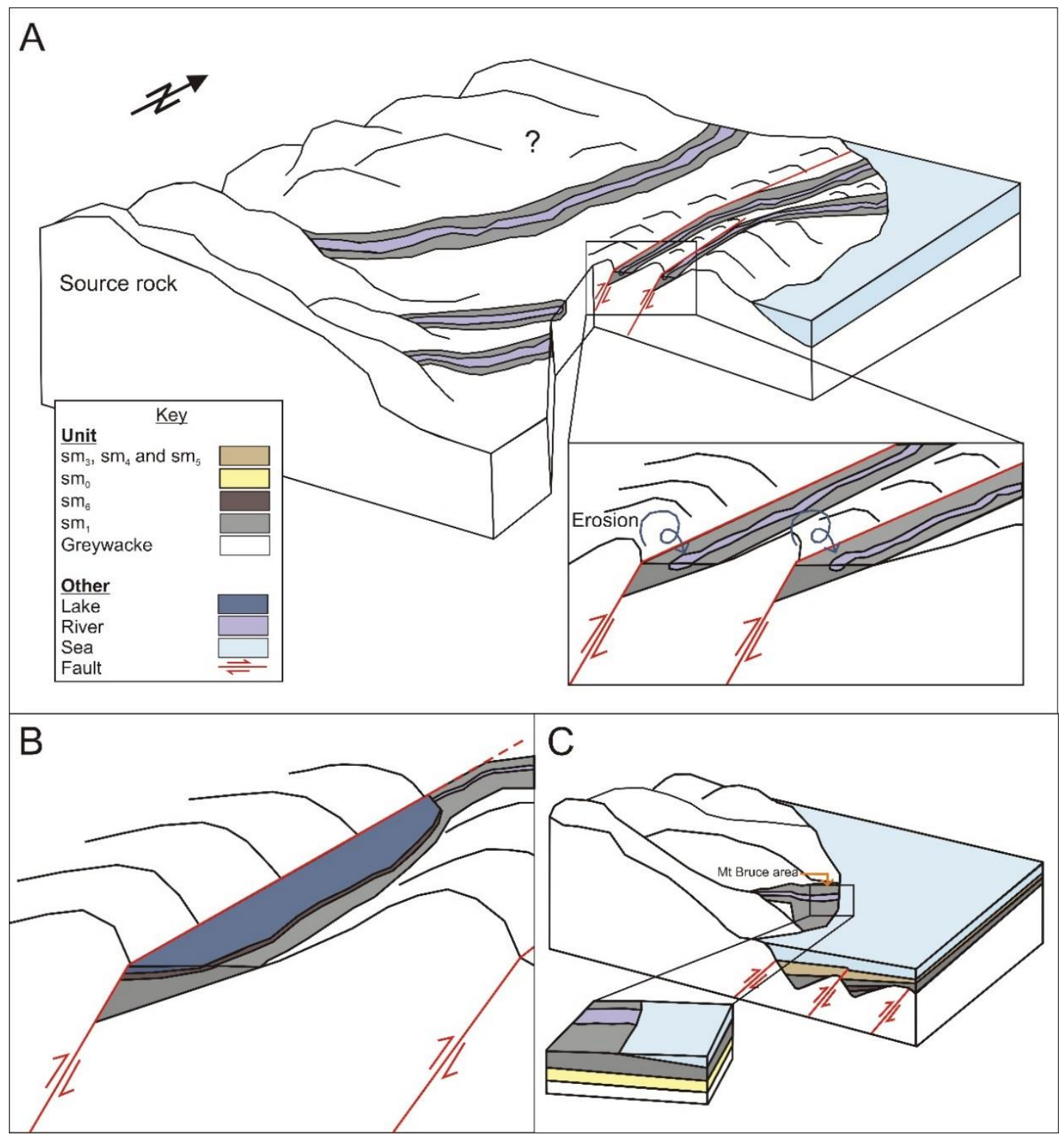

Figure 5.1: Schematic reconstruction of the Late Miocene paleogeography of north-west Wairarapa. A) Reconstruction of braided rivers depositing $\mathrm{sm}_{1}$ conglomerate in halfgrabens. B) Development of a north-south trending co-seismic lake. C) Marine transgression over part of north-west Wairarapa, leading to the sedimentation of the transgressive sequence of the upper Mangaoranga Formation $\left(\mathrm{sm}_{3}, \mathrm{sm}_{4}\right.$ and $\left.\mathrm{sm}_{5}\right)$. In the Mount Bruce area, an alluvial fan deposited conglomerate $\left(\mathrm{sm}_{1}\right)$ above an estuarial mudstone sequence $\left(\mathrm{sm}_{0}\right)$ before being submerged. 
5.2.4. Correlations to the wider Wairarapa region

The conglomerate $\left(\mathrm{sm}_{1}\right)$ of the Mangaoranga Formation is a correlative of Tongaporutuan conglomerates in southern Wairarapa, west and north-west of the Aorangi Range (Putangirua Conglomerate (Bates, 1967) and Sunnyside Conglomerate (Abbas, 1971; Vella \& Briggs, 1971) respectively). As with the Mangaoranga Formation conglomerate $\left(\mathrm{sm}_{1}\right)$, the conglomerates in southern Wairarapa unconformably overlie Mesozoic greywacke basement and consist of greywacke clasts up to boulder size. The Sunnyside Conglomerate is interpreted as being deposited by shallow marine debris flows (Vella \& Briggs, 1971) while the Putangirua Conglomerate is interpreted as being of alluvial origin (Bates, 1967).

The sporadic preservation of Tongaporutuan conglomerates in north-west and southern Wairarapa implies that areas of greywacke relief were exposed above sealevel during the Tongaporutuan. These areas may have been exposed for some time prior to sedimentation of the Tongaporutuan conglomerates, when any overlying Tertiary and Early Cretaceous strata were eroded.

The Tongaporutuan conglomerates in southern Wairarapa are overlain by marine transgressive sequences, as in north-western Wairarapa. The widespread preservation of marine transgressional sequences suggests that basin subsidence was occurring not only in north-western Wairarapa, but in the greater Wairarapa region.

\subsubsection{Vegetation cover}

The pollen analysed in the present study from the lacustrine $\left(\mathrm{sm}_{6}\right)$ and marine mudstone $\left(\mathrm{sm}_{5}\right)$ members was found to contain mixed warm and cool temperate species. These species were inferred to represent differences in regional elevation during the Late Miocene. The cool temperate flora is inferred to have occupied areas with higher elevations, while the warm temperate flora occupied lowland and coastal areas (Figure 5.2).

The altitude of the cool temperate zone during the Late Miocene is inferred to be similar to that of today. Wardle (1964) defined the current cool temperate zone of the Tararua Range as occurring between 416-915 m above sea level. Since 
temperatures during the Late Miocene were slightly warmer than today (e.g. Shackleton \& Kennett, 1975), it is inferred that the boundaries of the cool temperate zone during the Late Miocene were slightly higher, indicating a maximum relief for the surrounding areas of slightly more than $915 \mathrm{~m}$. A modern analogue for the slightly higher cool temperate zone is Te Moehau, Coromandel Peninsula, which has a slightly warmer average surface temperature than the Tararura Range (due to its lower latitude), but still has a cool temperate climate at altitude (Moore, 1973; Gardner \& Dodsworth, 1984).

The pollen assemblages recovered in this study suggest that much of north-west Wairarapa was covered in forests during the Late Miocene. In areas with higher elevations, cool temperate forests of beech taxa flourished (Figure 5.2). These forests contained minor elements of Podocarpus spp. and Phyllocladus spp. Common understory components were Coprosma spp.

On low-lying areas, warm temperate beech forests were common. These forests often contained elements of Dacrydium cupressinum type and tree ferns (Figure 5.2). In areas with impeded drainage, palms, Laurelia novaezelandiae and Dacrycarpus dacrydioides grew. The coastal areas were likely occupied by woodland forests of Metrosideros spp. and Casuarinaceae spp. (Figure 5.2).

The assemblages recovered from the Mangaoranga Formation suggest that the environment was wet during the Late Miocene, leading to the widespread development of rainforests. A possible cool and dry period is represented by the assemblage of KH1307, collected from the lacustrine deposits at the Mauriceville site.

The Late Miocene flora of north-western Wairarapa is analogous to contemporary forests along the west coast of the North Island and the upper west Coast of the South Island. Here forests receive high rainfall and are dominated by beech and podocarphardwood trees (Wardle, 1991). 


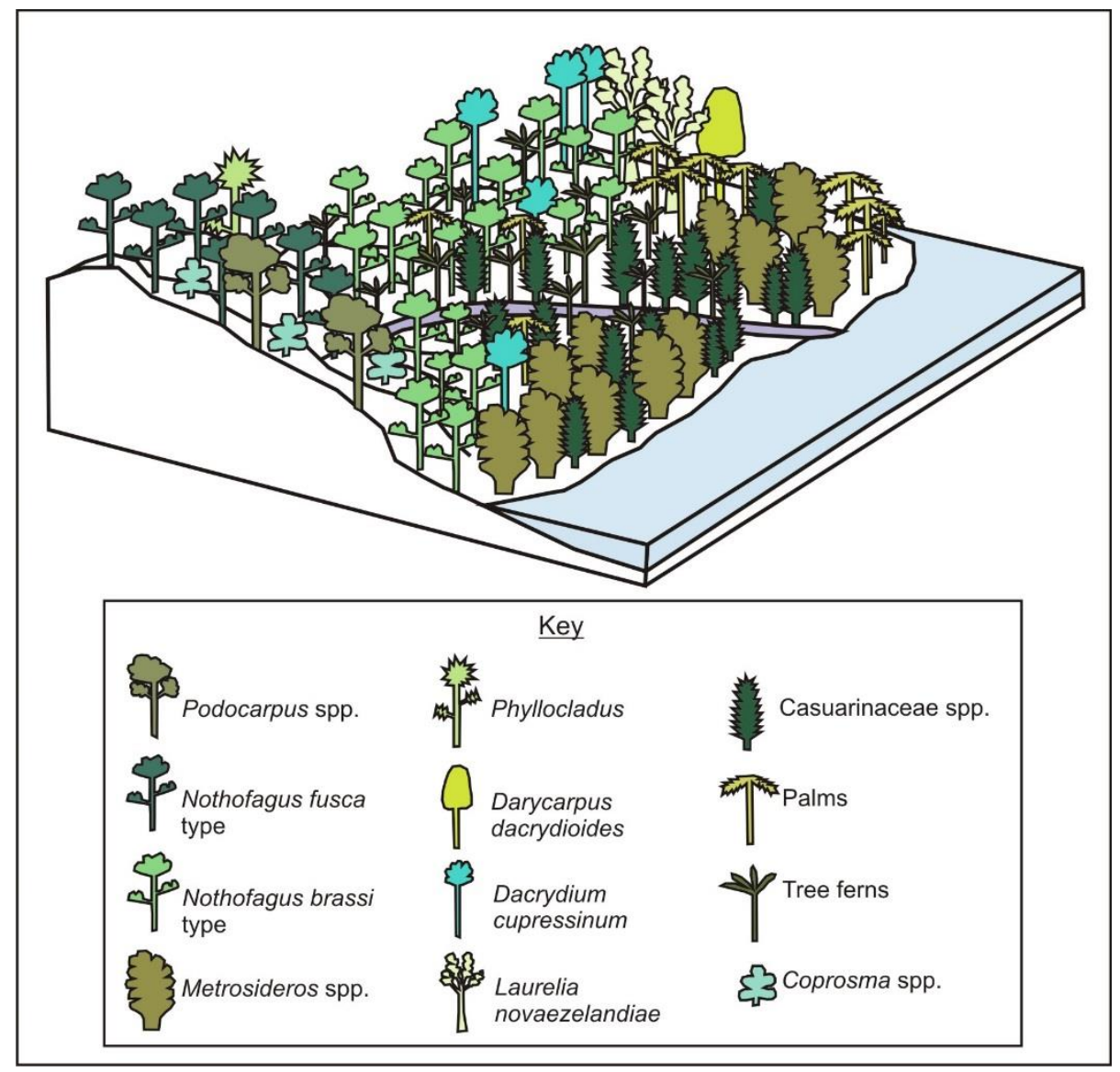

Figure 5.2: Generalised schematic reconstruction of the Late Miocene vegetation in north-west Wairarapa based on fossil pollen. This reconstruction includes only the most common species identified in this study. A full taxonomic list of all species identified in this study is supplied in Appendix 1.2.

\subsubsection{Kapitean sedimentation (Kaiparoro Formation)}

Following deposition of the Mangaoranga Formation marine transgressional sequence, a brief shallowing occurred, leading to deposition of the sediments of the Kaiparoro Formation. The formation conformably overlies $\mathrm{sm}_{5}$ of the Mangaoranga Formation in areas of north-west Wairarapa, and consists of shallow marine siltstone, sandstone, conglomerate and limestone (Figure 2.1: Neef, 1984). Foraminifera from the sandstone and siltstone members suggest a Kapitean age for the formation, and also indicate a shallowing of $120 \mathrm{~m}$ during deposition (Kennett, 1966).

The deposition of these shallow marine deposits resulted from sea-level fall due to glaciations at high latitudes (Kennett et al., 1971; Kennett \& Watkins, 1974; Kennett, 
1977). Evidence of shallowing seas in other areas of the Wairarapa is not well recorded and, instead, marine transgressional sequences are preserved in the stratigraphic record (e.g. Palliser Bay: Bates, 1967). However, at Cape Turnagain, eastern Wairarapa, a Kapitean shallowing event is recorded in the stratigraphic record as siltstone grades upwards into fine sandstone (Moore, 1981). 


\subsection{Summary of the Pliocene to Quaternary geological evolution of Wairarapa}

\subsubsection{Pliocene - Early Pleistocene}

Subsidence of the much of the Wairarapa region continued into the Pliocene, subsequently resulting in the ongoing deposition of transgressional sequences. Deposition of these transgressive sequences culminated in the Early Pliocene, when a change in the regional tectonics resulted in widespread uplift and subsequent deposition of a Late Pliocene marine regressive sequence (Onoke Group, Figure 2.1). Wells (1989b) suggested that ramping of the Australian Plate over the unlocked portion of the Pacific Plate during the Late Pliocene resulted in crustal flexure, leading to rapid uplift of the axial and coastal ranges and subsequent shallowing of the Wairarapa landmass.

In the western Wairarapa, basin subsidence led to the deposition of the mudstonedominated deposits of the lower Eketahuna Group above the underlying Upper Miocene and older sediments (Neef, 1984). Analysis of foraminifera from these deposits suggests that sedimentation occurred in water depths of up to $1700 \mathrm{~m}$ (Neef, 1984). Following the deposition of these sediments, basin uplift occurred, producing widespread shelf conditions until the mid-Early Pleistocene (Neef, 1984; Lamarche et al., 1995). This shallowing led to the deposition of a marine regressive sequence, containing the sandstone-dominated deposits of the upper Eketahuna Group, Makuri Group and Totaranui Formation (Neef, 1984). In total, 1200 m of Pliocene - Early Pleistocene sediments were preserved in the stratigraphic record above the Mangaoranga and Kaipororo formations in western Wairarapa (Neef, 1984). This implies burial to depths not much greater than $1200 \mathrm{~m}$, consistant with greywacke burial depths estimated using the apatite fission-track results $(3-2.4 \mathrm{~km})$.

Similar sedimentary sequences representing deepening through the Early Pliocene and subsequent shallowing during the Late Pliocene and Early Pleistocene occur in central and eastern Wairarapa also. These areas include the north-western area of the Aorangi Range (Vella \& Briggs, 1971), Palliser Bay (Bates, 1967), Wainuioru, east of Masterton (Crundwell, 1997) and Castlepoint (Johnston, 1973). Widespread coquina limestone represents the Early Pleistocene shallowing in many places (e.g. 
the Pukenui Limestone, north-western area of the Aorangi Range: Vella \& Briggs, 1971).

\subsubsection{Quaternary}

Following deposition of the Early Pleistocene shallow marine deposits, rapid uplift of the axial ranges occurred, resulting in an increase in compressional faulting and folding of the region, an increase in coarse-grained Late Quaternary sedimentation and the subsequent emergence of the Wairarapa landmass above sea level (Lamarche et al., 1995; Neef, 1984). Wells (1989b) suggested that the emergence of the landmass occurred at an average rate of $1.5 \mathrm{~mm} / \mathrm{yr}$ over the past $2 \mathrm{Ma}$ (deduced from decompacted sedimentary columns and palaeo-water depths). At $\sim 1$ Ma, compressional faulting relaxed and strike-slip motion commenced (Lamarche et al., 1995; Kelsey et al., in press). It is suggested that the switch to strike-slip motion was the possible result of the rotation of the southern Hikurangi margin (Beanland, 1995; Lamarche et al., 1995; Kelsey et al., in press). Over the last 100,000 - 200, 000 years, the rates of surface uplift have rapidly increased to $3-4.5 \mathrm{~mm} / \mathrm{yr}$, as inferred from the analysis of uplifted marine benches (Ghani, 1978).

Quaternary sediments in the Wairarapa region dominantly consist of alluvial, marginal marine and lacustrine deposits. These deposits are widespread in western and central Wairarapa; however, they are limited in extent in eastern Wairarapa (Figure 2.1). 


\subsection{Implications}

The stratigraphic and floral analyses made as part of this study have allowed for a better understanding of the Late Miocene paleogeography and vegetation of northwest Wairarapa, while the fission-track analysis has allowed part of the exhumation and subsequent burial history of the basement strata to be determined. Although there is no new direct evidence as to the geological history of north-west Wairarapa prior to Late Miocene deposition, the apatite fission-track results suggest that, with cooling and hence exhumation of the basement strata from at least $36-25 \mathrm{Ma}$ to around $11-7 \mathrm{Ma}$, there was likely to have been little to no deposition in the region over this time. If sedimentation did occur, it was likely to have been of a regressive sequence that was subsequently removed during exhumation. It is unclear whether sedimentation occurred in this region prior to the 36 - 35 Ma basement exhumation; however, if sedimentation did occur, the strata were also removed during the $36-25$ to $11-7$ Ma basement exhumation episode. 


\section{Conclusions}

The key findings of this study are summarised below:

- Detailed mapping and stratigraphic descriptions of the Mangaoranga Formation at Mangaoranga Stream, Eketahuna, have led to a revision of the lithological description and stratigraphic thickness of some members of the formation initially proposed by Neef (1984).

- A new unit, sm$_{6}$ interbedded sandstone and mudstone, is here proposed to identify the terrestrial sandstone and mudstone member at the Mangaoranga Stream and Mauriceville sites. The considerable thickness of this member, combined with its lithology, indicates that deposition occurred in a large fault-bound lake, which likely persisted for some $95 \mathrm{ky}$.

- Widespread basin subsidence at a rate of $0.28 \mathrm{~mm} / \mathrm{yr}$ led to the deposition of the marine transgressive sequence of the upper Mangaoranga Formation $\left(\mathrm{sm}_{3}, \mathrm{sm}_{4}\right.$ and $\left.\mathrm{sm}_{5}\right)$. This transgression reached maximum water depths of $600 \pm 300 \mathrm{~m}$ by the late Tongaporutuan .

- Mixed warm and cool temperate pollen species were extracted from the Mangaoranga Formation, indicating that differences in elevation of possibly $900 \mathrm{~m}$ existed on land during the Late Miocene. In areas with higher elevations, cool temperate beech forests grew, while on low-lying and coastal areas, warm temperate beech forests and woodland forests of Metrosideros spp. and Casuarinaceae spp. grew.

- Apatite fission-track ages for greywacke basement below the Mangaoranga Formation in north-western Wairarapa are $36-25 \mathrm{Ma}$, implying that at this time the basement strata were at a depth below the surface with temperatures of $110{ }^{\circ} \mathrm{C}(\sim 5 \mathrm{~km})$. The basement strata subsequently cooled to the surface by uplift at rates of $0.36-0.20 \mathrm{~mm} / \mathrm{yr}$ (using a geothermal gradient of 20 
${ }^{\circ} \mathrm{C} / \mathrm{km}$ ) or $0.28-0.16 \mathrm{~mm} / \mathrm{yr}$ (using a geothermal gradient of $25{ }^{\circ} \mathrm{C} / \mathrm{km}$ ), where they were exposed above sea level between $11-7 \mathrm{Ma}$.

- The apatite fission-track ages of the basement strata have not been reset. This implies that the basement strata, and hence overlying Neogene sediments, were not later buried to depths with temperatures greater than $60^{\circ} \mathrm{C}$, or depths of more than $3-2.4 \mathrm{~km}$. 


\section{Reference List}

Abbas, S. H. (1971). Some aspects of the sedimentology of Pliocene and Miocene rocks north of Aorangi Range, Wairarapa, sheet N165 (Unpublished master's thesis). Victoria University of Wellington, Wellington, New Zealand.

Abid, R., Alam, J., \& Qaiser, M. (2010). Pollination mechanism and the role of insects in Abutilon indicum (L.) Sweet. Pakistan Journal of Botany, 42(3), 1395-1399.

Adams, C. J., \& Graham, I. J. (1996). Metamorphic and tectonic geochronology of the Torlesse Terrane, Wellington, New Zealand. New Zealand Journal of Geology and Geophysics, 3(2), 157-180.

Adams, C. J., Graham, I. J., \& Johnson, M. R. (1999). Age and isotopic characterisation of geological terranes in Marlborough Schist, Nelson/Marlborough, New Zealand. New Zealand Journal of Geology and Geophysics, 42(1), 33-35.

Aita, Y., \& Spörli, K. B. (1992). Tectonic and paleobiogeographic significance of radiolarian microfaunas in the Permian to Mesozoic basement rocks of the North Island, New Zealand. Palaeogeography, Palaeoclimatology, Palaeoecology, 96, 103-125.

Andrews, P. B., Speden, I. G., \& Bradshaw, J. D. (1976). Lithological and palaeontological content of the Carboniferous-Jurassic Canterbury Suite, South Island, New Zealand. New Zealand Journal of Geology and Geophysics, 19(6), 791-819.

Ballance, P. F. (1993). The paleo-Pacific, post-subduction, passive margin thermal relaxation sequence Late Cretaceous-Paleogene of the drifting New Zealand continent. In P. F. Balance (Ed.), South Pacific Sedimentary Basins, Sedimentary Basins of the World 2 (Vol. 2, pp. 93-110). Amsterdam: Elsevier.

Bannister, J. M., Conran, J. G., \& Lee, D.E. (2012). Lauraceae from forests surrounding a maar lake, Otago, southern New Zealand. Review of Palaeobotany and Palynology, 178, 13-34. 
Bates, T. E. (1967). The geology of the northern Aorangi Range and part of Palliser Bay Sheet N165 (Unpublished master's thesis). Victoria University of Wellington, Wellington, New Zealand.

Beanland, S. (1995). The North Island Dextral Fault Belt, Hikurangi Subduction Margin, New Zealand (Unpublished doctoral thesis). Victoria University of Wellington, Wellington, New Zealand.

Bernet, M., Brandon, M. T., Garver, J. I., Reiners, P. W., \& Fitzgerald, P. G. (2002). Determining the zircon fission-track closure temperature. GSA Cordilleran Section, 98 ${ }^{\text {th }}$ annual meeting, Abstract with Programs, 34(18).

Beu, A. G. (1970). Bathyal upper Miocene Mollusca from Wairarapa district, New Zealand. Transactions of the Royal Society of New Zealand, 7(12), 209-240.

Bradshaw, J. D. (1973). Allochthonous Mesozoic fossil localities in melange in the Torlesse Group of North Canterbury. Journal of the Royal Society of New Zealand, 3(2), 161-167.

Bradshaw, J. D., Andrews, P. B., \& Adams, C. J. (1981). Carboniferous to Cretaceous on the Pacific margin of Gondwana: the Rangitata Phase of New Zealand. In M. M. Cresswell, \& P. Vella (Ed.), Gondwana Five (pp. 217 221). Proceedings of the Fifth International Gondwana Symposium, Wellington, New Zealand: Balkema, Rotterdam.

Brandon, M. T., Roden-Tice, M. K., \& Garver, J. I. (1998). Late Cenozoic exhumation of the Cascadia accretionary wedge in the Olympic Mountains, northwest Washington State. Geological Society of America Bulletin, 110(8), 985-1009.

Campbell, M. H. (1990). Distribution, ecology and control of Cassinia arcuate (sifton bush) in New South Wales. Australian Journal of Experimental Agriculture, 30(2), 215 - 220.

Carter, R. M., Hicks, M. D., Norris, J. R., \& Turnbull, I. M. (1978). Sedimentation patterns in an ancient arc-trench-ocean basin complex: Carboniferous to Jurassic Rangitata Orogen, New Zealand. In D. J. Stanley, \& G. Kelling (Ed.), Sedimentation in submarine canyons, fans and trenches (pp. 340-361). Stroudsburg, Pennsylvania: Dowden, Hutchinson \& Ross.

Clarkson, B. D. (1990). A review of vegetation development following recent $(<450$ years) volcanic disturbance in North Island, New Zealand. New Zealand Journal of Ecology, 14, 59-71. 
Collen, J. D., \& Vella, P. P. (1984). Hautotara, Te Muna and Ahiaruhe formations, middle to late Pleistocene, Wairarapa, New Zealand. Journal of the Royal Society of New Zealand, 14, 297-317.

Coombs, D. S., \& Cox, S. C. (1991). Low- and very low-grade metamorphism in southern New Zealand and its geological setting. Geological Society of New Zealand Miscellaneous Publications, 58, 1-87.

Coombs, D. S., Landis, C. S., Norris, R., Carter, R. A., Borns, D., \& Craw, D. (1976). The Dun Mountain ophiolite belt, New Zealand, its tectonic setting, constitution, and origin, with special reference to its southern portion. American Journal of Science, 26, 561-603.

Crampton, J. S. (1997). The Cretaceous stratigraphy of the southern Hawkes Bay Wairarapa region. Institute of Geological and Nuclear Sciences science report, 97/98. 1-90.

Crundwell, M. P. (1997). Neogene lithostratigraphy of southern Wairarapa. Institute of Geological and Nuclear Sciences science report, 97/36, 1-114.

Culley, T. M., Weller, S. G., \& Sakai, A. K. (2002). The evolution of wind pollination in angiosperms. Trends in Ecology and Evolution, 17(8), 361 369.

Darby, D. J., \& Beanland, S. (1992). Possible Source Models for the 1855 Wairarapa Earthquake, New Zealand. Journal of Geophysical Research, 97, 12375 12389.

Dawson, J. W., \& Sneddon, B. V. (1969). The New Zealand rain forest: a comparison with tropical rain forest. Pacific Science, 23(2), 131-147.

Donelick, R. A., O’Sullivan, P. B., \& Ketcham, R. A. (2005). Apatite fission-track analysis. Reviews in Mineralogy \& Geochemistry, 58, 49-94.

Enright, N. J., \& Watson, A. D. (1992) Population dynamics of the nikau palm, Rhopalostylis sapida (Wendl. et Drude), in a temperate forest remnant near Auckland, New Zealand. New Zealand Journal of Botany, 30(1), 29-43.

Faegri, K., Kaland, P. E., \& Krzywinski, K. (1989). Textbook of pollen analysis (4 $^{\text {th }}$ ed.). New York: Wiley. 
Ferguson, D. K., Lee, D. E., Bannister, J. M., Zetter, R., Jordan, G. J., Vavra, N., \& Mildenhall, D. C. (2010). The taphonomy of a remarkable leaf bed assemblage from the Late Oligocene - Early Miocene Gore Lignite Measures, southern New Zealand. International Journal of Coal Geology, 83, 173-181.

Field, B. D., Uruski, C. I., Beu, A. G., Browne, G. H., Crampton, J. S., Funnell, R., Killops, S., Laird, M. G., Mazengarb, C., Morgans, H. E. G., Rait, G. J., Smale, D., \& Strong, C. P. (1997). Cretaceous-Cenozoic geology and petroleum systems of the East Coast region, New Zealand. Institute of Geological and Nuclear Sciences Monograph, 19.

Franceschinelli, E. V. (2005).The pollination biology of two species of Helicteres (Malvaceae) with different mechanisms of pollen deposition. Flora Morphology, Distribution, Functional Ecology of Plants, 200(1), 65-73.

Gahni, M. A. (1978). Late Cenozoic vertical crustal movements in the southern North Island, New Zealand. New Zealand Journal of Geology and Geophysics, 21, 117-125.

Galbraith, R. F. (2005). Statistics for fission-track analysis. Boca Raton, Florida, USA: Chapman and Hall/CRC.

Gardner, P. O., \& Dodsworth, J. S. (1984). Native vascular plants of Moehau. Newsletter of the Auckland Botanical Society, 39(1), 6-9.

Gleadow, A. J. W., Duddy, I. R., Green, P. F., \& Lovering, J. F. (1986). Confined fission-track lengths in apatite: a diagnostic tool for thermal history analysis. Contributions to Mineralogy and Petrology, 94, 405-415.

Graham, I. J. (2008). A continent on the move: New Zealand geoscience into the $21^{\text {st }}$ century. Geological Society of New Zealand miscellaneous publication, 124, $1-388$.

Havinga, A. J. (1967). Palynology and pollen preservation. Review of Palaeobotany and Palynology, 2, 81-98.

Heenan, P. B., \& McGlone, M. S. (2012). Evolution of New Zealand alpine and open-habitat plant species during the Late Cenozoic. New Zealand Journal of Ecology, 37(1), 105-113. 
Herendeen, P. S., Crepet, W. L., \& Nixon, K. C. (1994). Fossil flowers and pollen of Lauraceae from the Upper Cretaceous of New Jersey. Plant Systematics and Evolution, 189, 29-40.

Holden, A. M. (1982b). Fossil Lauraceae and Proteaceae from the Longford Formation, Murchison, New Zealand. Journal of the Royal Society of New Zealand, 12, 79-90.

Holden, A. M. (1983). Studies in New Zealand Oligocene and Miocene plant macrofossils (Unpublished doctoral thesis). Victoria University of Wellington, Wellington, New Zealand.

Hsü, K. J., Montadert, L., Bernoulli, D., Cita, M. B., Erikson, A., Garrison, R. E., Kidd, R. B., Mèlierés, F., Müller, C., \& Wright, R. (1977). History of the Mediterranean salinity crisis. Nature, 267, 399-403.

Hurford, A. J. (1986). Cooling and uplift patterns in the Lepontine Alps South Central Switzerland and an age of vertical movement on the Insubric fault line. Contributions to Mineralogy and Petrology, 92, 413-427.

Hurford, A. J., \& Green, P. F. (1983). The zeta age calibration of fission-track dating. Chemical Geology, 41, 285-317.

Ivanovic, R. F., Valdes, P. J., Flecker, R., \& Gutjahr, M. (2013). Modelling global scale climate impacts of the late Miocene Messinian Salinity Crisis. Climate of the Past Discussions, 9(4), 4807-4854.

Jackson, S. T., \& Kearsley, J. B. (1998). Quantitative representation of local forest composition in forest-floor pollen assemblages. Journal of Ecology, 86(3), 474-490.

Jacobson, G. L., \& Bradshaw, R. H. W. (1981). The selection of sites for paleovegetational studies. Quaternary Research. 16(1), 80-96.

Jarzen, D. M., \& Nichols, D. J. (1996). Pollen. In J. Jansonius, \& D. C. McGregor (Ed.), Palynology: Principles and Applications (Vol. 1, pp. 261-291). American Association of Stratigraphic Palynologists Foundation.

Johnston, M. R. (1973). Geology of Castlepoint headland and reef, Wairarapa, New Zealand. New Zealand Journal of Geology and Geophysics, 16(4), 909-916.

Johnston, M. R. (1980). Geology of the Tinui-Awatoitoi District, New Zealand. New Zealand Geological Survey bulletin, 94. 
Kelsey, H. M., Cashman, S. M., Beanland, S., \& Berryman, K. R. in press. Structural evolution along the inner part of the obliquely convergent Hikurangi margin, New Zealand. Tectonics.

Kelsey, H. M., Erdman, C. F., \& Cashman, S. M. (1993). Geology of southern Hawke's Bay from the Maraetotara Plateau and Waipawa westward to the Wakarara Range and the Ohara Depression. Institute of Geological and Nuclear Sciences science report, 92/93.

Kemp, E. M. (1976). Early Tertiary pollen from Napperby, central Australia. Journal of Australian Geology and Geophysics, 1(2), 109-114.

Kennett, J. P. (1966). Biostratigraphy and paleoecology in Upper Miocene-Lower Pliocene sections in Wairarapa and southern Hawkes Bay. Transactions of the Royal Society of New Zealand (Geology), 4, 83-102.

Kennett, J. P. (1967). Recognition and correlation of the Kapitean Stage (Upper Miocene, New Zealand). New Zealand Journal of Geology and Geophysics, 10(4), 1051-1063.

Kennett, J.P. (1977). Cenozoic evolution of Antarctic glaciation, the circumAntarctic Ocean, and their impact on global paleoceanography. Journal of Geophysical Research, 82(27), 3843-3860.

Kennett, J. P., Watkins, N. D., \& Vella, P. (1971). Paleomagnetic chronology of Pliocene-early Pleistocene climates and the Plio-Pleistocene boundary in New Zealand. Science, 171, 276-279.

Kennett, J. P., \& Watkins, N. D. (1974). Late Miocene-early Pliocene paleomagnetic stratigraphy, paleoclimatology, and biostratigraphy in New Zealand. The Geological Society of America Bulletin, 85(9), 1385-1398.

Ketcham, R. A. (2005). Forward and inverse modelling of low-temperature thermochronometry data. Reviews in Mineralogy and Geochemistry, 58, 275 314.

Killops, S. D., Hollis, C. J., Morgans, H. E. G., Sutherland, R., Field, B. D., \& Leckie, D. A. (2000). Paleoceanographic significance of Late Paleocene dysaerobia at the shelf/slope break around New Zealand. Palaeogeography, Palaeoclimatology, Palaeoecology, 156, 51-70.

King, P. R. (2000). Tectonic reconstructions of New Zealand: 40 Ma to the Present. New Zealand Journal of Geology \& Geophysics, 43, 611-638. 
King, J. E., Klippel, W. E., \& Duffield, R. (1975). Pollen preservation and archaeology in Eastern North America. American Antiquity, 40(2), 180-190.

King, P. R., Naish, T. R., Browne, G. H., Field, B. D., \& Edbrooke, S. W. (1999). Cretaceous to Recent sedimentary patterns in New Zealand. Institute of Geological and Nuclear Sciences Folio Series, 1, 1-35.

Ladley, J. J., \& Kelly, D. (1996). Dispersal, germination and survival of New Zealand mistletoe (Loranthaceae): dependence on birds. New Zealand Journal of Ecology, 20(1), 69-79.

Lamarche, G., Beanland, S., \& Ravens, J. (1995). Deformation style and history of the Eketahuna region, Hikurangi forearc, New Zealand, from shallow seismic reflection data. New Zealand Journal of Geology and Geophysics, 38, 105 115.

Landis, C. A., \& Coombs, D. S. (1967). Metamorphic belts and orogenesis in southern New Zealand. Tectonophysics, 4, 501-518.

Lee, J. M., \& Begg, J. G. (2002). Geology of the Wairarapa area. Institute of Geological and Nuclear Sceinces 1:250,000 geological map 11 (p. $66+1$ sheet). Lower Hutt, New Zealand: Institute of Geological and Nuclear Sciences Limited.

Lewis, K. B. (1980). Quaternary sedimentation on the Hikurangi oblique-subduction and transform margin, New Zealand. In P. F. Balance, \& H. G. Reading (Ed.), Sedimentation in oblique-slip mobile zones (Vol. 4, pp. 171-189). Special Publication International Association of Sedimentologists.

Lynch, P. A., Ferguson, E. J., \& Hynes, P. (1972). The vegetation of Red Mercury Island, Part I: The plant communities and a vascular plant species list. Tane, 18, 21-29.

MacDougall, J. D. (1976). Fission-track dating. Scientific American, 235, 114-122.

Macphail, M. K., \& McQueen, D. R. (1983). The value of New Zealand pollen and spores as indicators of Cenozoic vegetation and climates. Tuatara, 26(2), 37 59.

McKay, A. (1896). Geology: general report and reports of special examinations made during the year 1895-1896. Appendix to the Journal of the House of Representatives, 1(C-11), 1-54. 
McQueen, D. R., Mildenhall, D. C., \& Bell, C. E. (1968). Paleobotanical evidence for changes in the Tertiary climate of New Zealand. Tuatara, 16(1), 49-56.

Mehltreter, K., Walker, L. R., \& Sharpe, J. M. (2010). Fern Ecology. Cambridge: Cambridge University Press.

Miall, A. D. (1996). The geology of fluvial deposits. Berlin: Springer.

Mildenhall, D. C. (1980). New Zealand Late Cretaceous and Cenozoic plant biogeography: a contribution. Palaeogeography, Palaeoclimatology, Palaeoecology, 31, 197-233.

Mildenhall, D. C. (1989). Summary of the age and paleoecology of the Miocene Manuherikia Group, Central Otago, New Zealand. Journal of the Royal Society of New Zealand, 19(1), 19-29.

Mildenhall, D. C., \& Pocknall, D. T. (1989). Miocene - Pleistocene spores and pollen from Central Otago, South Island, New Zealand. New Zealand Geological Survey paleontological bulletin, 59, 1-128.

Moore, L. B. (1973). Botanical note on three high peaks overlooking the Hauraki Gulf. Tane, 19, 213-220.

Moore, P. R. (1981). Geology of the Late Tertiary section at Cape Turnagain. Journal of the Royal Society of New Zealand, 11(3), 223-230.

Moore, P. R. (1988). Structural divisions of eastern North Island, New Zealand. New Zealand Geological Survey Record, 30.

Moore, P. R., \& Speden, I. G. (1979). Stratigraphy, structure and inferred environment of deposition of the Early Cretaceous sequence, eastern Wairarapa, New Zealand. New Zealand Journal of Geology and Geophysics, 22, 417-433.

Moore, P. R., Adams, A. G., Isaac, M. J., Mazengrab, C., Morgans, H. E. G., \& Phillips, C. C. (1986). A revised Cretaceous-early Tertiary stratigraphic nomenclature for eastern North Island. New Zealand Geological Survey report, G104, 1-31.

Moore, P. R., \& Morgans, H. E. G. (1987). Two new reference sections for the Wanstead Formation (Palaeocene-Eocene) in southern Hawkes Bay. New Zealand Geological Survey Record, 20, 81-87. 
Muller, J. (1981). Fossil pollen records of extant angiosperms. The Botanical Review, $47,1-142$.

Murakami, M., \& Svojtka, M. (2007). Zircon fission-track technique: a laboratory procedure adopted at the Institute of Geology, Academy of Sciences of the Czech Republic, v.v.i. Fission Track News Letter, 20, 13-19.

Naeser, C. W. (1976). The use of apatite and sphene for fission track age determination. The Geological Society of America Bulletin, 73, 1523-1526.

Naeser, C. W. (1979). Fission-track dating and geological annealing of fission tracks. In E. Jager, \& J. C. Hunziker (Ed.), Lectures in Isotope Geology (pp. 154 169). Berlin: Springer Berlin Heidelberg.

Neef, G. (1984). Late Cenozoic and early Quaternary stratigraphy of the Eketahuna District (N153). New Zealand Geological Survey bulletin, 96, 1-100.

Neef, G. (1999). Neogene development of the onland part of the forearc in northern Wairarapa, North Island, New Zealand: a synthesis. New Zealand Journal of Geology and Geophysics, 42(1), 113-135.

Norton, D. A., Herbert, J. W., \& Beveridge, A. E. (1988). The ecology of Dacrydium cupressinum: a review. New Zealand Journal of Botany, 26(1), 37-62.

Orbell, G. E. (1961). Geology of the Mauriceville District, New Zealand (Unpublished master's thesis). Victoria University of Wellington, Wellington, New Zealand.

Pandey, O. P. (1981). Terrestrial heat flow in New Zealand (Unpublished doctoral dissertation). Victoria University of Wellington, Wellington, New Zealand.

Parshall, T., \& Calcote, R. (2001). Effect of pollen from regional vegetation on stand scale forest reconstruction. The Holocene, 11(1), 81-87.

Playford, G., \& Dettmann, M. E. (1996). Spores. In J. Jansonius, \& D. C. McGregor (Ed.), Palynology: Principles and Applications (Vol. 1, pp. 227-260). American Association of Stratigraphic Palynologists Foundation.

Pocknall, D. T. (1982). Palynology of late Oligocene Pomahaka Estuarine Bed sediments, Waikoikoi, Southland, New Zealand. New Zealand Journal of Botany, 20(3), 263-28. 
Pocknall, D. T. (1990). Palynological evidence for the early to middle Eocene vegetation and climate history of New Zealand. Review of Palaeobotany and Palynology, 65(1-4), 57-69.

Pocknall, D. T., \& Mildenhall, D. C. (1984). Late Oligocene-early Miocene spores and pollen from Southland, New Zealand. New Zealand Geological Survey paleontological bulletin, 51, 1-66.

Pocknall, D. T., \& Turnbull, I. M. (1989). Paleoenvironmental and stratigraphic significance of palynomorphs from Upper Eocene (Kaiatan) Beaumont Coal Measures and Orauea Mudstone, Waiau Basin, western Southland, New Zealand. New Zealand Journal of Geology and Geophysics, 32, 371-278.

Price, P. B., \& Walker, R. M. (1963). Fossil tracks of charged particles in mica and the age of minerals. Journal of Geophysical Research, 68, 4847-4862.

Puttiwongrak, A., Honda, H., Matsuoka, T., \& Yamada, Y. (2013). Compaction curve with consideration of time and temperature effects for mudstones. Geotechnical Engineering Journal of the SEAGS \& AGSSEA, 44(1), 34-39.

Raine, J. I., Mildenhall, E. M., \& Kennedy, E. M. (2011). New Zealand fossil spores and pollen: an illustrated catalogue ( ${ }^{\text {th }}$ ed.). GNS Science miscellaneous series no. 4. http://data.gns.cri.nz/sporepollen/index.htm

Raju, A. J. S., Rao, S. P., \& Rangaiah, K. (2005). Pollination by bats and birds in the obligate outcrosser Bombax ceiba L. (Bombacaceae), a tropical dry season flowering tree species in the Eastern Ghats forests of India. Ornithological Science, 4(1), 81-87.

Raven, P. H. (1973). Evolution of subalpine and alpine plant groups in New Zealand. New Zealand Journal of Botany, 11, 177-200.

Reid, C. M. (1998). Stratigraphy, paleontology and tectonics of lower Miocene rocks in the Waipatiki/Mangatuna area, southern Hawkes Bay, New Zealand. New Zealand Journal of Geology and Geophysics, 41(2), 115-131.

Roser, B. P., Grapes, R. H., \& Palmer, K. (1995). XRF analyses of sandstones and argillites from the Torlesse terrane, New Zealand. Geology Board of Studies publication, 15 (Analytical Facility Contribution, 17), Victoria University of Wellington.

Scott, L., \& van Zinderen Barker, E. M. (1985). Exotic pollen and long-distance wind dispersal at a sub-Antarctic island. Grana, 24(1), 45-54. 
Shackleton, N. J., \& Kennett, J. P. (1975). Paleotemperature history of the Cenozoic and the initiation of Antarctic glaciation: oxygen and carbon isotope analyses in DSDP Sites 277, 279, and 281. In J. P. Kennett, R. E. Houtz et al., (Ed.), Initial Reports. DSDP (Vol. 29, pp. 743-755). Washington: U.S. Government Printing Office.

Shivanna, K. R., \& Johri, B. M. (1989). Angiosperm pollen: structure and function. The University of California: Wiley Eastern.

Shulmeister, J., Shane, P., Lian, O. B., Okuda, M., Carter, J. A., Harper, M., Dickinson, W., Augustinus P., \& Heijnis, H. (2001). A long late-Quaternary record from Lake Poukawa, Hawke's Bay, New Zealand. Palaeogeography, Palaeoclimatology, Palaeoecology, 176, 81-107.

Sparke, M., Wise, S., Bishop, D., \& Hill, D. (1984). Palynological sample processing guide. Australia: Esso Australia Ltd.

Speden, I. G. (1976). Fossil localities in Torlesse rocks of the North Island, New Zealand. Journal of the Royal society of New Zealand, 6(1), 73-91.

Spörli, K. B. (1980). New Zealand and oblique-slip margins: tectonic development up to and during the Cainozoic. In P. F. Balance, \& H. G. Reading (Ed.), Sedimentation in oblique-slip mobile zones (Vol. 4, pp. 147-170). Special Publication International Association of Sedimentologists.

Stewart, G. H., \& Veblen, T. T. (1982). Regeneration patterns in southern rata (Metrosideros umbellata) - kamahi (Weinmannia racemosa) forest in central Westland, New Zealand. New Zealand Journal of Botany, 20(1), 55-72.

Studt, F. E., \& Thompson, G. E. K. (1969). Geothermal heat flow in the North Island of New Zealand. New Zealand Journal of Geology and Geophysics, 12(4), 673-683.

Sugita, S. (1994). Pollen representation of vegetation in Quaternary sediments: theory and method in patchy vegetation. Journal of Ecology, 82(4), 881-97.

Sulman, J. D., Drew, B. T., Drummond, C., Hayasaka, E., \& Sytsma, J. (2013). Systematics, biogeography, and character evolution of Sparganium (Typhaceae): Diversification of a widespread, aquatic lineage. American Journal of Botany, 100(10), 2023-2039. 
Tagami, T., \& O'Sullivan, P. B. (2005). Fundamentals of fission-track thermochronology. Reviews in Mineralogy \& Geochemistry, 58, 19-47.

Tauber, H. (1965). Differential pollen dispersion and the interpretation of pollen diagrams: with a contribution to the interpretation of the Elm Fall. Denmark: I kommission hos C. A. Reitzel.

Thomson, G. M. (1927). The pollination of New Zealand flowers by birds and insects. Transactions of the New Zealand Institute, 57, 106-125.

Timmins, S. M. (1992). Wetland vegetation recovery after fire: Eweburn Bog, Te Anau, New Zealand. New Zealand Journal of Botany, 30(4), 383-399.

Traverse, A. (1988). Paleopalynology ( $1^{\text {st }}$ ed.). London: Unwin Hyman.

Trodahl, M. I. (2011). Late Holocene Sediment Deposition in Lake Wairarapa (Unpublished master's thesis). Victoria University of Wellington, Wellington, New Zealand.

Turner, J. R., \& Hawkeswood, T. J. (1996). Taxonomy, biology, geographic distribution and conservation of the rare Australian jewel beetle, Stigmodera (Castiarina) armata Thomson (Coleoptera: Buprestidae). Giornale italiano di Entomologia, 8, 191-206.

Van der Lingen, G. J., \& Pettinga, J. R. (1980). The Makara Basin: a Miocene slope basin along the New Zealand sector of the Australian-Pacific obliquely convergent plate boundary. In P. F. Balance, \& H. G. Reading (Ed.), Sedimentation in oblique-slip mobile zones (Vol. 4, pp. 191-215). Special Publication International Association of Sedimentologists.

Vella, P., \& Briggs, W. M. (1971). Lithostratigraphic names, Upper Miocene to Lower Pleistocene, northern Aorangi Range, Wairarapa. New Zealand Journal of Geology and Geophysics, 14(2), 253-274.

Wagner, G., \& Van den Haute, P. (1992). Fission track dating. Dordrecht: Kluwer Academic Publishers.

Walcott, R. I. (1984). Reconstructions of the New Zealand region for the Neogene. Palaeogeography, Palaeoclimatology, Palaeoecology, 46, 217-231.

Wardle, P. (1964). Facets of the distribution of forest vegetation in New Zealand. New Zealand Journal of Botany, 2, 352-366. 
Wardle, P. (1974). The kahikatea (Dacrycarpus dacrydioides) forest of south Westland. Proceedings of the New Zealand Ecological Society, 21, 62-71.

Wardle, P. (1991). Vegetation of New Zealand. Cambridge: Cambridge University Press.

Wells, P. E. (1985). The geology of the Mt Bruce area (Unpublished Bachelor of Science (Honours) thesis). Victoria University of Wellington, Wellington, New Zealand.

Wells, P. E. (1989a). Late Neogene stratigraphy of the Carrington area, western Wairarapa, North Island, New Zealand. Journal of the Royal Society of New Zealand, 19(3), 283-303.

Wells, P. E. (1989b). Burial history of Late Neogene sedimentary basins on part of the New Zealand convergent plate margin. Basin Research, 2, 145-160.

Williams, J. B., Harden, G. J., \& McDonald, W. J. F. (1984). Trees and shrubs in rainforests of New South Wales and Southern Queensland. University of New England, Armidale NSW: Botany Department.

Wilmshurst, J. M., Higham, T. F. G., Allen, H., Johns, D., \& Phillips, C. (2004). Early Maori settlement impacts in northern coastal Taranaki, New Zealand. New Zealand Journal of Ecology, 28(2), 167-179.

Yamada, R., Tagami, T., Nishimura, S., \& Ito, H. (1995). Annealing kinetics of fission tracks in zircon: an experimental study. Chemical Geology, 122, 249258.

Yee, T. W., \& Mitchell, N. D. (1991). Generalized additive models in plant ecology. Journal of Vegetation Science, 2(5), 587-602. 
Appendices 
Appendix 1.1. - Palynological processing techniques

\section{Palynological processing techniques 1}

1. $\sim 5 \mathrm{~g}$ of sub-sample was removed from the bulk sample and transferred into a $100 \mathrm{ml}$ polypropylene beaker. The sample was broken down into small pieces using a polypropylene stirring rod then placed inside a fume hood.

2. The sample was treated with hydrochloric acid $(\mathrm{HCl})$ to remove carbonates. $\mathrm{HCl}$ treatment procedure

- $\quad 10-15 \mathrm{ml}$ of $10 \% \mathrm{HCl}$ was added to the sample.

- The sample was stirred using a polypropylene stirring rod then left for 10 minutes.

- If a reaction occurred, the sample was treated with more $\mathrm{HCl}$ and left to settle until no reaction occurred when fresh $\mathrm{HCl}$ was added.

3. The sample was treated with hydrofluoric (HF) acid to remove siliceous material.

\section{$\underline{\text { HF acid treatment procedure }}$}

- Several drops of $40 \%$ HF acid were added to the sample.

- If a violent reaction did not occur, $15-20 \mathrm{ml}$ of HF acid was added to the sample.

- The sample was carefully stirred using a polypropylene stirring rod then left uncovered overnight to settle.

- Once settled, the supernatant was decanted into a large polypropylene container and neutralised with soda ash.

Note: at no stage did a violent reaction occur with any sample.

4. The residue was washed with filtered water to remove any trace of the previous solution.

Water-wash process

- 4a. Filtered water was added to the residue until the beaker was $3 / 4$ full.

- The sample was stirred and left to settle.

- When the supernatant liquid was perfectly clear, it was decanted into the polypropylene container and neutralised with soda ash.

- Step 4a was repeated twice more.

- $20 \mathrm{ml}$ of filtered water was added to the remaining residue. 
- The sample was stirred and poured into a $50 \mathrm{ml}$ polypropylene centrifuge tube.

- Filtered water was used to rinse the residue left on the walls of the beaker into the tube.

- $\quad$ 4b. $35 \mathrm{ml}$ of filtered water was added to the residue.

- $\quad$ The sample was agitated then centrifuged at 2600 r.p.m. for 5 minutes.

- The supernatant was decanted.

- Step $\mathbf{4 b}$ was repeated twice more.

5. The residue was washed in $\mathrm{HCl}$ to remove any acid soluble fluorides from the sample.

\section{$\underline{\mathrm{HCl} \text { wash procedure }}$}

- $\quad$ 20 $\mathrm{ml}$ of $10 \% \mathrm{HCl}$ was added to the residue.

- The sample was agitated, topped up with filtered water and centrifuged at 2600 r.p.m. for 5 minutes.

- The supernatant was decanted into a glass beaker and neutralised with soda ash.

- $\quad$ The residue was water-washed as in step $\mathbf{4 b}$.

6. The residue was oxidised in a cold schulze solution to concentrate the palynomorphs in the sample.

\section{Cold schulze treatment procedure}

- In a glass measuring cylinder, a solution of 2:1 $10 \%$ nitric acid $\left(\mathrm{HNO}_{3}\right)$ and saturated potassium chlorate $\left(\mathrm{KCLO}_{3}\right)$ was prepared.

- Approximately $20 \mathrm{ml}$ of schulze solution was added to the residue.

- An electronic timer was used to time the moment the schulze solution came in contact with the residue. To determine the oxidation time span for a sample, water slides were made before the oxidation process to assess the organic fraction concentration. Initially, the samples were oxidised for 10 minutes to begin with, then the organic fraction assessed. The samples were further oxidised if required.

- The sample was vigorously stirred using a polypropylene stirring rod several times throughout the time span.

- Immediately after the required time had elapsed, the solution was quickly diluted with filtered water and centrifuged at 2600 r.p.m. for 3 minutes. 
- The supernatant was decanted into a $500 \mathrm{ml}$ glass beaker and neutralised with soda ash.

- $\quad$ The residue was water-washed as in step $4 \mathbf{b}$ - at 2600 r.p.m. for 3 minutes.

7. The residue was washed in ammonia to dissolve the humic acids that were not dissolved during the oxidation process.

Ammonia wash procedure

- Approximately $20 \mathrm{ml}$ of $10 \%$ ammonia $\left(\mathrm{NH}_{4} \mathrm{OH}\right)$ was added to the residue.

- The sample was agitated then topped up with filtered water.

- $\quad$ The sample was centrifuged at 2600 r.p.m for 3 minutes.

- The supernatant was decanted.

- The residue was water-washed, as in step $\mathbf{4 b}$, up to seven times (at 2600 r.p.m. for 3 minutes) until the supernatant was perfectly clear.

8. The residue was washed in $\mathrm{HCl}$.

\section{$\underline{\text { HCL wash procedure }}$}

- $5 \mathrm{ml}$ of $10 \% \mathrm{HCl}$ was added to the residue.

- The sample was agitated then topped up with filtered water.

- The sample was centrifuged at 2600 r.p.m. for 3 minutes.

- The supernatant was decanted into a glass beaker and neutralised with soda ash.

9. Sodium-polytungstate ( $\mathrm{SPT}, 3 \mathrm{Na}_{2} \mathrm{WO}_{4} 9 \mathrm{WO}_{3} \mathrm{H}_{2} \mathrm{O}$ ) was added to the residue to separate the organic residue from the remaining material.

Organic residue separation procedure

- Approximately $35 \mathrm{ml}$ of SPT (specific gravity 2.0) was added to the residue.

- The sample was agitated vigorously.

- The sample was centrifuged at 1800 r.p.m. for 15 minutes.

- The sample was left to settle overnight.

10. The organic layer (the 'float') that had settled above the SPT was removed and placed in a $10 \mathrm{ml}$ conical-bottom centrifuge tube.

\section{$\underline{\text { Removal of float procedure }}$}

- The floating organic residue was removed from the SPT using disposable Pasteur pipettes.

- The float was transferred into a $10 \mathrm{ml}$ conical-bottom centrifuge tube.

- The tube was topped up with filtered water and agitated vigorously. 
- The sample was centrifuged at 2000 r.p.m. for 5 minutes.

- The supernatant was decanted.

- The residue was water-washed, as in step 4b, up to 6 times (at 2600 r.p.m. for 3 minutes) until all of the SPT was removed.

Note: In some cases, a significant amount of SPT was transferred into the $10 \mathrm{ml}$ conical-bottom centrifuge tube while pipetting the organic float from the $50 \mathrm{ml}$ centrifuge tube. As a result, after the first centrifuge, some of the organic residue remained in suspension within the supernatant. When this occurred, a slightly different water-wash method to that above was used.

\section{$\underline{\text { Removal of residue in suspension procedure }}$}

- Half the supernatant and suspended organic material was poured into a second $10 \mathrm{ml}$ conical-bottom centrifuge tube.

- Both tubes were topped up with filtered water and agitated.

- $\quad$ The samples were centrifuged at 2000 r.p.m. for 5 minutes.

- At this stage, if there was still not a good separation of organic material from supernatant in one of the tubes, the supernatant was decanted into a clean 50 $\mathrm{ml}$ centrifuge tube. The material in the $50 \mathrm{ml}$ centrifuge tube was set aside. The remaining residue in the $10 \mathrm{ml}$ tube was washed with filtered water, as in step $\mathbf{4 b}$, until clean of SPT (centrifuged at 2000 r.p.m. for 5 minutes).

- The supernatant in the second $10 \mathrm{ml}$ tube was decanted and the remaining residue washed with filtered water, as in step $\mathbf{4 b}$, until clean of SPT (centrifuged at 2000 r.p.m. for 5 minutes).

- The residue in both $10 \mathrm{ml}$ tubes was combined, with filtered water used to remove any residue left on the tube walls.

- The $50 \mathrm{ml}$ tube was topped up with filtered water and centrifuged at 2000 r.p.m. for 5 minutes until clean of SPT.

- The residue was recombined with the residue in the smaller tube.

11. Water mounts were made and the samples inspected under a binocular microscope to examine the degree of oxidation. 


\section{Mounting technique}

- A hotplate was set to approximately $35^{\circ} \mathrm{C}$.

- A glass slide was labelled with a felt-tip pen and placed on the hot plate. Several slides were made per sample.

- One drop of glycerine jelly was placed on the slide.

- $5 \mathrm{ml}$ of filtered water was added to the organic residue to dilute the sample.

- Using disposable Pasteur pipettes, one drop of the diluted sample was placed on the glycerine jelly.

- Using a clean toothpick, the glycerine jelly and sample were carefully mixed and spread over an area on the slide less than the area of the cover slip.

- The sample was left to cool and thicken slightly - around 10 minutes.

- The cover slip was carefully lowered onto the sample using a clean toothpick beneath the slip for leverage.

- The hotplate was switched off and the sample left to harden for 30 minutes.

- The slide was inverted and placed on top of two parallel glass stirring rods. This ensured that the grains were set in one viewing plane.

- The slide was left until set.

- The outer edge of the cover slip was cleaned using ethanol and a clean paper towel.

- The outer edge was then sealed using clear nail polish.

- The slide was inspected under a binocular microscope. If at this stage it was found that more oxidation was required, steps $\mathbf{5}-\mathbf{1 0}$ were repeated.

12. When the sample was sufficiently oxidised, the final mounts were made. This was done by following the technique outlined in step 10, with a slight variation. Mounting variations

- $\quad 1-2$ drops of both the glycerine jelly and the sample were used on the final slide, depending on the palynomorph concentration.

- Once the sample had been pipetted onto the slide, a small drop of safranin $\left(\mathrm{C}_{20} \mathrm{H}_{19} \mathrm{CIN}_{4}\right)$ was placed on the slide to stain the palynomorphs. The safranin staining was carried out to in order to improve the quality of the grains when photographed. 


\section{Palynological processing techniques 2}

Note: The procedures outlined below were carried out on every sample. Eight samples were processed in every batch.

1. $\sim 5 \mathrm{~g}$ of sub-sample was removed from the bulk sample and transferred into a $50 \mathrm{ml}$ centrifuge tube. The centrifuge tube was held in a polypropylene holding rack. The sample was split using a polypropylene stirring rod and transferred into a fume hood.

2. Hydrochloric acid $(\mathrm{HCl})$ was added to the sample to remove carbonates.

\section{$\underline{\text { HCL treatment procedure }}$}

- $\quad 10-15 \mathrm{ml}$ of $10 \% \mathrm{HCl}$ was added to the sample.

- The sample was stirred using a polypropylene stirring rod then left for 10 minutes.

- If a reaction occurred, the sample was treated with more $\mathrm{HCl}$ and left to settle until no new reaction occurred when fresh $\mathrm{HCl}$ was added.

- The sample was toped up with filtered water until $3 / 4$ full.

- The sample was centrifuged at 3000 r.p.m. for 5 minutes.

- The supernatant was decanted into a $500 \mathrm{ml}$ glass beaker and neutralised with soda ash.

- The residue was water-washed as in step 3a.

3. The residue was washed with filtered water to remove any trace of the previous solution.

\section{Water-wash process}

- 3a. $35 \mathrm{ml}$ of filtered water was added to the residue.

- The sample was agitated then centrifuged at 3000 r.p.m. for 5 minutes.

- The supernatant was decanted.

- Step 3a was repeated twice more.

- $\quad 3$ b. $5 \mathrm{ml}$ of filtered water was added to the residue.

- The sample was agitated then centrifuged at 3000 r.p.m. for 5 minutes.

- The supernatant was decanted.

- Step $\mathbf{3 b}$ was repeated twice more.

4. Dilute Calgon was added to the residue to disaggregate the sediments. 


\section{Calgon disaggregation procedure}

- $35 \mathrm{ml}$ of $0.5 \%$ Calgon was added to the residue.

- The sample was agitated vigorously then placed in a water-bath set at $\sim 80^{\circ} \mathrm{C}$.

- Using an electronic stop watch to time, the sample was left in the water-bath for exactly 45 minutes.

- When 45 minutes had elapsed, the sample was removed from the water-bath and centrifuged at 3000 r.p.m for 5 minutes.

- The supernatant was decanted.

- The residue was water-washed as in step 3a.

5. Potassium hydroxide $(\mathrm{KOH})$ was added to the residue to separate the palynomorphs from surrounding matrix and neutralise the humic acids.

\section{$\underline{\mathrm{KOH} \text { treatment procedure }}$}

- $\quad 35 \mathrm{ml}$ of $10 \% \mathrm{KOH}$ was added to the residue.

- The sample was agitated then placed in a water-bath set at $\sim 80^{\circ} \mathrm{C}$.

- Using an electronic stop watch to time, the sample was left in the water-bath for exactly 15 minutes.

- When 15 minutes had elapsed, the sample was removed from the water-bath and centrifuged at 3000 r.p.m for 5 minutes.

- The supernatant was decanted.

- The residue was water-washed as in step 3a.

6. The residue was washed twice with glacial acetic acid $\left(\mathrm{C}_{2} \mathrm{H}_{4} \mathrm{O}_{2}\right)$ to remove the water from the previous step.

\section{Glacial acetic acid treatment procedure}

- $35 \mathrm{ml}$ of glacial acetic acid was added to the residue.

- The sample was agitated then centrifuged for 5 minutes at 3000 r.p.m.

- The supernatant was decanted into a 11 glass beaker.

- The residue was washed with glacial acetic acid once more.

- The supernatant was neutralised using soda ash.

7. The residue underwent acetolysis to remove the cellulose material. This process increased the pollen and spore concentration.

Acetolysis procedure

- A solution of 9:1 acetic anhydride $\left(\mathrm{C}_{4} \mathrm{H}_{6} \mathrm{O}_{3}\right)$ and concentrated sulphuric acid $\left(\mathrm{H}_{2} \mathrm{SO}_{4}\right)$ was prepared in a $500 \mathrm{ml}$ glass beaker - for 8 samples $(25 \mathrm{ml}$ each) 
$180 \mathrm{ml}$ of acetic anhydride and $20 \mathrm{ml}$ of concentrated sulphuric acid was used.

- The solution was stirred immediately using two disposable Pasteur pipettes.

- $10 \mathrm{ml}$ of the solution was added to the residue using the same two pipettes.

- The sample was slowly agitated.

- Another $15 \mathrm{ml}$ of the solution was added to the sample.

- The sample was placed in a water-bath set at $96^{\circ} \mathrm{C}$.

- Using an electronic stop watch to time, the sample was left in the water-bath for exactly 5 minutes.

- When 2 minutes had elapsed, the lids were quickly unscrewed to remove any gases, and then tightly refastened.

- When 5 minutes had elapsed, the sample was removed from the water-bath and immediately placed in a sink of cold water for 30 seconds (cold water was used to cool the sample).

- The sample was centrifuged at 3000 r.p.m for 5 minutes.

- The supernatant was decanted into a 11 glass beaker and neutralised using soda ash.

8. The residue underwent two glacial acetic acid washes as in step $\mathbf{6}$, to remove the acetolysis solution.

9. The sample underwent three water-washes as in step 3a.

10. Sodium-polytungstate (SPT, $3 \mathrm{Na}_{2} \mathrm{WO}_{4} 9 \mathrm{WO}_{3} \mathrm{H}_{2} \mathrm{O}$ ) was added to the residue to separate the organic residue from the remaining material.

Organic residue separation procedure

- Approximately $35 \mathrm{ml}$ of SPT (specific gravity 2.0) was added to the residue.

- The sample was agitated vigorously.

- The sample was centrifuged at 2000 r.p.m. for 15 minutes.

- The sample was left to settle overnight.

11. The organic layer (the 'float') that had settled above the SPT was removed and placed in a $10 \mathrm{ml}$ conical-bottom centrifuge tube ready for water-washing. Removal of float procedure

- A $6 \mu \mathrm{m}$ sieve cloth was fastened between two polypropylene cylinders. The sieving apparatus was placed on top of a polypropylene funnel. The tip of the funnel was then placed inside a conical glass flask. 
- The organic float was carefully poured over the $6 \mu \mathrm{m}$ sieve cloth. The SPT and $<6 \mu$ m organic float filtered through the cloth into the flask while the $>6$ $\mu \mathrm{m}$ float stuck to the sieve cloth. A $6 \mu \mathrm{m}$ sieve cloth was used to help concentrate the pollen and spores.

- When all the SPT had filtered through the cloth, the cloth was removed from the funnel and held over a clean polypropylene funnel inside a clean $50 \mathrm{ml}$ centrifuge tube.

- The organic residue was rinsed off the cloth and through the funnel into the centrifuge tube using filtered water.

- Filtered water was added to the tube until it was $3 / 4$ full.

- $\quad$ The sample was centrifuged for 5 minutes at 3000 r.p.m.

- The supernatant was decanted.

- $5 \mathrm{ml}$ of filtered water was added to the residue.

- The sample was agitated until all the residue was in suspension in the water.

- The sample was quickly poured into a $10 \mathrm{ml}$ conical centrifuge tube.

- One drop of safranin $\left(\mathrm{C}_{20} \mathrm{H}_{19} \mathrm{CIN}_{4}\right)$ was added to the sample to stain the pollen and spores. The safranin staining was carried out to improve the quality of the palynomorphs when photographed.

- The sample was water-washed as in step $\mathbf{3 b}$.

12. The residue was mounted onto standard glass slides ready for examination. Mounting technique

- A hotplate was set to approximately $35^{\circ} \mathrm{C}$.

- A glass slide was labelled with a felt-tip pen and placed on the hot plate. 2 3 slides were made per sample.

- 2 drops of filtered water were added to the organic residue to dilute the sample.

- The sample was vigorously agitated.

- Three drops of glycerine jelly were placed on the slide.

- Using clean disposable Pasteur pipettes, two drops of the diluted sample were placed on the glycerine jelly.

- Using a clean toothpick, the glycerine jelly and sample were carefully mixed and spread over an area on the slide less than the area of the cover slip.

- The sample was left to cool and thicken slightly - around 10 minutes. 
- The cover slip was carefully lowered onto the sample using a clean toothpick beneath the slip for leverage.

- The hotplate was switched off and the sample left to harden for 30 minutes.

- The slide was inverted and placed on top of two parallel glass stirring rods. This ensured that the grains were set in one viewing plane.

- The slide was left until set.

- The outer edge of the cover slip was cleaned using ethanol and a clean paper towel.

- The outer edge was then sealed using clear nail polish.

- The slide was inspected under a binocular microscope. 
Appendix 1.2. - Taxonomic lists

$\underline{\text { Full taxonomic list and natural affinity }}$

\section{Natural affinity}

$\mathrm{GF}$ - ground fern spores

$\mathrm{S}$ - shrub pollen

$\mathrm{TF}$ - tree fern spores

$\mathrm{H}$ - herb pollen

PH - podocarp-hardwood pollen

$\mathrm{C}$ - climber pollen

AS - arboreal swamp pollen

E - epiphyte pollen

NB - Nothofagus brassi type pollen

GRASS - grass-like pollen

NF - Nothofagus fusca type pollen

UA - unknown affinity

AOTHER - other arboreal pollen

\begin{tabular}{|c|c|}
\hline Palynomorph & Affinity \\
\hline \multicolumn{2}{|l|}{ SPORES } \\
\hline \multicolumn{2}{|l|}{ Monolete } \\
\hline Monoletes & GF \\
\hline Polypodiisporites inangahuensis (Couper 1953) Potonie 1956 & GF \\
\hline Polypodiisporites variscabratus Mildenhall \& Pocknall 1989 & GF \\
\hline Polypodiisporites minimus (Couper 1960) Khan \& Martin 1971 & GF \\
\hline Polypodiisporites radiatus Pocknall \& Mildenhall 1984 & GF \\
\hline Polypodiisporites spp. & GF \\
\hline \multicolumn{2}{|l|}{ Trilete } \\
\hline Cyathea type & TF \\
\hline Baculatisporites spp. & GF \\
\hline Gemmatriletes multiglobus Mildenhall \& Pocknall 1989 & GF \\
\hline Foveotriletes lacunosus Partridge 1973 & $\mathrm{H}$ \\
\hline Foveotriletes verrucosus Pocknall \& Mildenhall 1984 & TF \\
\hline Cibotiidites tuberculiformis (Cookson 1947) Skarby 1974 & $\mathrm{TF}$ \\
\hline Rugulatisporites cowrensis (Martin 1973) Mildenhall \& Pocknall 1989 & GF \\
\hline Gleicheniidites senonicus Ross 1949 & GF \\
\hline Polypodiaceoisporites papuanus (Khan 1976) Pocknall 1985 & GF \\
\hline Polypodiaceoisporites tumulatus Partridge in Stover \& Partridge 1973 & GF \\
\hline Ricciaesporites kawaraensis Mildenhall \& Pocknall 1989 & $\mathrm{H}$ \\
\hline \multicolumn{2}{|l|}{ POLLEN } \\
\hline \multicolumn{2}{|l|}{ Saccites } \\
\hline Dacrydiumites praecupressinoides (Couper 1953) Truswell 1983 & $\mathrm{PH}$ \\
\hline Microalatidites paleogenicus (Cookson \& Pike 1954) Mildenhall \& Pocknall 1989 & $\mathrm{PH}$ \\
\hline Pinus spp. & - \\
\hline Podocarpus spp. & $\mathrm{PH}$ \\
\hline
\end{tabular}




\begin{tabular}{|c|c|}
\hline Dacrycarpites australiensis Cookson \& Pike 1953 & AS \\
\hline \multicolumn{2}{|l|}{ Apiculati } \\
\hline Araucariacites australis Cookson 1947 & $\mathrm{PH}$ \\
\hline \multicolumn{2}{|l|}{ Monosulcates } \\
\hline Arecipites otagoensis (Couper 1960) Mildenhall \& Pocknall 1989 & AS \\
\hline Arecipites cf. Rhopalostylis sapida Wendl. \& Drude & AS \\
\hline Arecipites spp. & AS \\
\hline Liliacidites variegatus Couper 1953 & AS \\
\hline Liliacidites spp. & $\mathrm{H}$ \\
\hline Monogemmites gemmatus (Couper 1960) Krutzsch 1970 & $\mathrm{H}$ \\
\hline Monogemmites sp. Krutzsch 1970 & $\mathrm{E}$ \\
\hline \multicolumn{2}{|l|}{ Tricolpates } \\
\hline Cranwellia striata (Couper 1953) Srivastava 1966 & UA \\
\hline \multicolumn{2}{|l|}{ Stephanocolpates } \\
\hline Nothofagidites cranwelliae (Couper 1953) Mildenhall \& Pocknall 1989 & NB \\
\hline Nothofagidites falcatus (Cookson 1959) Hekel 1972 & NB \\
\hline Nothofagus fusca type & $\mathrm{NF}$ \\
\hline Nothofagidites lachlaniae (Couper 1953) Pocknall \& Mildenhall 1984 & $\mathrm{NF}$ \\
\hline Nothofagidites matauraensis (Couper 1953) Hekel 1972 & NB \\
\hline Nothofagidites spinosus (Couper 1960) Mildenhall \& Pocknall 1989 & NB \\
\hline Nothofagidites undifferentiated & $\mathrm{NU}$ \\
\hline Reevesiapollis reticulatus (Couper 1960) Krutzsch 1970 & AOTHER \\
\hline \multicolumn{2}{|l|}{ Polycolpates } \\
\hline Glencopollis ornatus Pocknall \& Mildenhall 1984 & $\mathrm{H}$ \\
\hline \multicolumn{2}{|l|}{ Syncolporates } \\
\hline Gothanipollis bassensis Stover in Partridge \& Stover 1973 & $\mathrm{~S}$ \\
\hline Gothanipollis gothani Krutzsch 1959 & $\mathrm{~S}$ \\
\hline Myrtaceidites eugeniioides Cookson \& Pike 1954 & AOTHER \\
\hline Myrtaceidites mesonesus Cookson \& Pike 1954 & $\mathrm{PH}$ \\
\hline \multicolumn{2}{|l|}{ Tricolporates } \\
\hline Asteraceae spp. & $\mathrm{S}$ \\
\hline Bombacacidites bombaxoides Couper 1960 & $\mathrm{PH}$ \\
\hline Ericipites longisulcatus Wodehouse 1933 & $\mathrm{~S}$ \\
\hline Ligulifloridites sp. & $\mathrm{H}$ \\
\hline Palaeocoprosmadites zelandiae Pocknall 1982 & $\mathrm{~S}$ \\
\hline Rhoipites alveolatus (Couper 1953) Pocknall \& Crosbie 1982 & UA \\
\hline Rhoipites spp. & $\mathrm{UA}$ \\
\hline Tricolporites scabratus Harris 1965 & $\mathrm{UA}$ \\
\hline Tricolporites spp. & UA \\
\hline Tubulifloridites antipodica Cookson 1947 & $\mathrm{~S}$ \\
\hline Tubulifloridites pleistocenicus Martin 1973 & $\mathrm{~S}$ \\
\hline Tubulifloridites simplis Martin 1973 & $\mathrm{~S}$ \\
\hline Tubuliflorae spp. & $\mathrm{S}$ \\
\hline Monoporates & \\
\hline
\end{tabular}




\begin{tabular}{|l|c|}
\hline Graminidites media Cookson 1947 & GRASS \\
\hline Lateropora glabra Pocknall \& Mildenhall 1984 & C \\
\hline Sparganiaceaepollenites barungensis Harris 1972 & H \\
\hline Sparganiaceaepollenites sphericus (Couper 1960) Mild. in Mild. \& Crosbie 1979 & $\mathrm{H}$ \\
\hline Triporates & \\
\hline Myricipites harrisii (Couper 1953) Dutta \& Sah 1970 & AOTHER \\
\hline Proteacidites minimus Couper 1954 & PH \\
\hline Proteaceae spp. & AOTHER \\
\hline Triorites minor Couper 1953 & UA \\
\hline Triorites spp. & UA \\
\hline Stephanoporates & \\
\hline Haloragacidites amolosus Partridge in Stover \& Partridge 1973 & H \\
\hline Malvacipollis subtilis Stover in Stover \& Partridge 1973 & S \\
\hline Polyporates & \\
\hline Cyperaceaepollis neogenicus Krutzsch 1970 & H \\
\hline Malvacearumpollis mannanensis Wood 1986 & AOTHER \\
\hline Parsonsidites psilatus Couper 1960 & C \\
\hline
\end{tabular}


$\underline{\text { Alfedton section - taxonomic list }}$

\begin{tabular}{|l|c|}
\hline Sample & Alfredton \\
\hline Number of slides observed & 1 \\
\hline Total count & 250 \\
\hline
\end{tabular}

\begin{tabular}{|l|c|}
\hline Taxonomic Name & Count \\
\hline SPORES & \\
\hline Monolete & 5 \\
\hline Monoletes & \\
\hline Monosulcates & 1 \\
\hline Arecipites otagoensis (Couper 1960) Mildenhall \& Pocknall 1989 & 42 \\
\hline Arecipites cf. Rhopalostylis sapida Wendl. \& Drude & 19 \\
\hline Liliacidites variegatus Couper 1953 & \\
\hline Stephanocolpates & 1 \\
\hline Nothofagidites cranwelliae (Couper 1953) Mildenhall \& Pocknall 1989 & 1 \\
\hline Nothofagidites spinosus (Couper 1960) Mildenhall \& Pocknall 1989 & 4 \\
\hline Nothofagidites undifferentiated & 2 \\
\hline Syncolporates & 83 \\
\hline Myrtaceidites eugeniioides Cookson \& Pike 1954 & \\
\hline Myrtaceidites mesonesus Cookson \& Pike 1954 & 40 \\
\hline Tricolporates & 18 \\
\hline Palaeocoprosmadites zelandiae Pocknall 1982 & 17 \\
\hline Rhoipites alveolatus (Couper 1953) Pocknall \& Crosbie 1982 & 1 \\
\hline Rhoipites spp. & \\
\hline Tricolporites spp. & 8 \\
\hline Monoporates & 1 \\
\hline Sparganiaceaepollenites barungensis Harris 1972 & 3 \\
\hline Sparganiaceaepollenites sphericus (Couper 1960) Mild. in Mild. \& Crosbie 1979 & \\
\hline Triporates & \\
\hline Myricipites harrisii (Couper 1953) Dutta \& Sah 1970 & \\
\hline Proteaceae spp. & \\
\hline Polyporates & \\
\hline Malvacearumpollis mannanensis Wood 1986 & \\
\hline
\end{tabular}


Central Mangaone Road section - taxonomic list

\begin{tabular}{|l|c|c|c|}
\hline Sample number & KH1304 & KH1310 & KH1311 \\
\hline Number of slides observed & 2 & 1 & 1 \\
\hline Total count & 0 & 250 & 250 \\
\hline
\end{tabular}

\begin{tabular}{|c|c|c|}
\hline \multirow{2}{*}{$\begin{array}{l}\text { Taxonomic Name } \\
\text { SPORES }\end{array}$} & \multicolumn{2}{|c|}{ Count } \\
\hline & & \\
\hline \multicolumn{3}{|l|}{ Monolete } \\
\hline Monoletes & 9 & 11 \\
\hline $\begin{array}{l}\text { Polypodiisporites inangahuensis (Couper 1953) Potonie } \\
1956\end{array}$ & & 1 \\
\hline $\begin{array}{l}\text { Polypodiisporites variscabratus Mildenhall \& Pocknall } \\
1989\end{array}$ & & 2 \\
\hline Polypodiisporites spp. & 6 & 8 \\
\hline \multicolumn{3}{|l|}{ Trilete } \\
\hline Cyathea type & 66 & 48 \\
\hline Baculatisporites spp. & 3 & \\
\hline Gemmatriletes multiglobus Mildenhall \& Pocknall 1989 & 1 & 1 \\
\hline Cibotiidites tuberculiformis (Cookson 1947) Skarby 1974 & 14 & 18 \\
\hline $\begin{array}{l}\text { Polypodiaceoisporites tumulatus Partridge in Stover \& } \\
\text { Partridge } 1973\end{array}$ & 3 & 1 \\
\hline Ricciaesporites kawaraensis Mildenhall \& Pocknall 1989 & & 3 \\
\hline \multicolumn{3}{|l|}{ POLLEN } \\
\hline \multicolumn{3}{|l|}{ Saccites } \\
\hline $\begin{array}{l}\text { Dacrydiumites praecupressinoides (Couper 1953) } \\
\text { Truswell } 1983\end{array}$ & 12 & 24 \\
\hline Podocarpus spp. & & 1 \\
\hline Dacrycarpites australiensis Cookson \& Pike 1953 & 1 & 1 \\
\hline \multicolumn{3}{|l|}{ Apiculati } \\
\hline $\begin{array}{l}\text { Arecipites otagoensis (Couper 1960) Mildenhall \& } \\
\text { Pocknall } 1989\end{array}$ & 4 & 6 \\
\hline Arecipites cf. Rhopalostylis sapida Wendl. \& Drude & 2 & 5 \\
\hline Liliacidites variegatus Couper 1953 & 1 & \\
\hline Monogemmites gemmatus (Couper 1960) Krutzsch 1970 & 3 & \\
\hline \multicolumn{3}{|l|}{ Stephanocolpates } \\
\hline $\begin{array}{l}\text { Nothofagidites cranwelliae (Couper 1953) Mildenhall \& } \\
\text { Pocknall } 1989\end{array}$ & 8 & 7 \\
\hline Nothofagus fusca type & 25 & 19 \\
\hline Nothofagidites matauraensis (Couper 1953) Hekel 1972 & & 6 \\
\hline Nothofagidites undifferentiated & 16 & 17 \\
\hline Reevesiapollis reticulatus (Couper 1960) Krutzsch 1970 & 3 & \\
\hline \multicolumn{3}{|l|}{ Polycolpates } \\
\hline Glencopollis ornatus Pocknall \& Mildenhall 1984 & & 3 \\
\hline \multicolumn{3}{|l|}{ Syncolporates } \\
\hline Gothanipollis gothani Krutzsch 1959 & 1 & \\
\hline Myrtaceidites mesonesus Cookson \& Pike 1954 & 14 & 2 \\
\hline
\end{tabular}




\begin{tabular}{|c|c|c|}
\hline \multicolumn{3}{|l|}{ Tricolporates } \\
\hline Ligulifloridites sp. & & 1 \\
\hline Palaeocoprosmadites zelandiae Pocknall 1982 & 10 & 32 \\
\hline Tricolporites spp. & 9 & 6 \\
\hline Tubulifloridites antipodica Cookson 1947 & 3 & \\
\hline Tubulifloridites pleistocenicus Martin 1973 & 2 & 1 \\
\hline Tubulifloridites simplis Martin 1973 & 5 & 4 \\
\hline \multicolumn{3}{|l|}{ Monoporates } \\
\hline Graminidites media Cookson 1947 & & 7 \\
\hline \multicolumn{3}{|l|}{ Triporates } \\
\hline Myricipites harrisii (Couper 1953) Dutta \& Sah 1970 & 11 & 9 \\
\hline Proteaceae spp. & 3 & 1 \\
\hline \multicolumn{3}{|l|}{ Stephanoporates } \\
\hline Malvacipollis subtilis Stover in Stover \& Partridge 1973 & 2 & \\
\hline \multicolumn{3}{|l|}{ Polyporates } \\
\hline Malvacearumpollis mannanensis Wood 1986 & 11 & 5 \\
\hline Parsonsidites psilatus Couper 1960 & 2 & \\
\hline
\end{tabular}


Mangaoranga Stream section - taxonomic list

\begin{tabular}{|l|c|c|c|c|c|c|c|}
\hline Sample number & KH1308-a & KH1308-b & KH1312 & KH1313 & KH1308-c & KH1308-d & KH1314 \\
\hline Number of slides observed & 5 & 2 & 1 & 1 & 1 & 2 & 5 \\
\hline Total count & 250 & 250 & 250 & 250 & 250 & 2 & 250 \\
\hline
\end{tabular}

\begin{tabular}{|c|c|c|c|c|c|c|c|}
\hline \multirow{2}{*}{\begin{tabular}{|l} 
Taxonomic Name \\
SPORES \\
\end{tabular}} & \multicolumn{7}{|c|}{ Count } \\
\hline & & & & & & & \\
\hline \multicolumn{8}{|l|}{ Monolete } \\
\hline Monoletes & 39 & 46 & 12 & 4 & 20 & & 38 \\
\hline $\begin{array}{l}\text { Polypodiisporites variscabratus Mildenhall } \\
\text { \& Pocknall } 1989\end{array}$ & & & & 2 & & & 3 \\
\hline Polypodiisporites spp. & 1 & 1 & 1 & & & & 10 \\
\hline \multicolumn{8}{|l|}{ Trilete } \\
\hline Cyathea type & 39 & 10 & 26 & 5 & 6 & & 46 \\
\hline $\begin{array}{l}\text { Cibotiidites tuberculiformis (Cookson 1947) } \\
\text { Skarby } 1974\end{array}$ & 2 & & & & & 2 & 1 \\
\hline $\begin{array}{l}\text { Rugulatisporites cowrensis (Martin 1973) } \\
\text { Mildenhall \& Pocknall } 1989\end{array}$ & 2 & & & & & & \\
\hline Gleicheniidites senonicus Ross 1949 & 1 & & & & & & \\
\hline \multicolumn{8}{|l|}{ POLLEN } \\
\hline \multicolumn{8}{|l|}{ Saccites } \\
\hline $\begin{array}{l}\text { Dacrydiumites praecupressinoides (Couper } \\
\text { 1953) Trus well } 1983\end{array}$ & 7 & & 5 & & & & 15 \\
\hline $\begin{array}{l}\text { Microalatidites paleogenicus (Cookson \& } \\
\text { Pike 1954) Mildenhall \& Pocknall } 1989\end{array}$ & 1 & & & & & & \\
\hline Pinus spp. & 1 & & & & & & \\
\hline Podocarpus spp. & 1 & 3 & 2 & & & & 6 \\
\hline $\begin{array}{l}\text { Dacrycarpites australiensis Cookson \& Pike } \\
1953\end{array}$ & & 1 & & & & & \\
\hline \multicolumn{8}{|l|}{ Monosulcates } \\
\hline $\begin{array}{l}\text { Arecipites otagoensis (Couper 1960) } \\
\text { Mildenhall \& Pocknall } 1989\end{array}$ & 23 & 12 & 15 & 8 & 15 & & \\
\hline $\begin{array}{l}\text { Arecipites } \text { cf. Rhopalostylis sapida } \text { Wendl. } \\
\& \text { Drude }\end{array}$ & 18 & 8 & 33 & 67 & 13 & & 8 \\
\hline Arecipites spp. & & 13 & & & & & \\
\hline Liliacidites variegatus Couper 1953 & 26 & 6 & 4 & 4 & 3 & & 3 \\
\hline Liliacidites spp. & 5 & 2 & & & & & \\
\hline Monogemmites sp. Krutzsch 1970 & & & & & 2 & & \\
\hline \multicolumn{8}{|l|}{ Tricolpates } \\
\hline $\begin{array}{l}\text { Cranwellia striata (Couper 1953) Srivastava } \\
1966\end{array}$ & & 1 & & & & & \\
\hline \multicolumn{8}{|l|}{ Stephanocolpates } \\
\hline $\begin{array}{l}\text { Nothofagidites cranwelliae (Couper 1953) } \\
\text { Mildenhall \& Pocknall } 1989\end{array}$ & 1 & 9 & & & 6 & & 3 \\
\hline $\begin{array}{l}\text { Nothofagidites falcatus (Cookson 1959) } \\
\text { Hekel } 1972\end{array}$ & 8 & 8 & & & 4 & & \\
\hline Nothofagus fusca type & & 22 & 5 & 1 & 25 & & 10 \\
\hline $\begin{array}{l}\text { Nothofagidites lachlaniae (Couper 1953) } \\
\text { Pocknall \& Mildenhall } 1984\end{array}$ & & 3 & 1 & & & & \\
\hline $\begin{array}{l}\text { Nothofagidites matauraensis (Couper 1953) } \\
\text { Hekel } 1972\end{array}$ & 3 & 1 & 2 & & 4 & & 3 \\
\hline $\begin{array}{l}\text { Nothofagidites spinosus (Couper 1960) } \\
\text { Mildenhall \& Pocknall } 1989\end{array}$ & & 1 & 1 & & 1 & & \\
\hline Nothofagidites undifferentiated & 59 & 68 & 4 & 6 & 48 & & 23 \\
\hline $\begin{array}{l}\text { Reevesiapollis reticulatus (Couper 1960) } \\
\text { Krutzsch } 1970\end{array}$ & & & & & 4 & & \\
\hline
\end{tabular}




\begin{tabular}{|c|c|c|c|c|c|c|}
\hline Syncolporates & & & & & & \\
\hline $\begin{array}{l}\text { Gothanipollis bassensis Stover in Partridge } \\
\text { \& Stover } 1973\end{array}$ & 1 & & & & & \\
\hline Gothanipollis gothani Krutzsch 1959 & & & 5 & 1 & & 1 \\
\hline $\begin{array}{l}\text { Myrtaceidites eugeniioides Cookson \& Pike } \\
1954\end{array}$ & & & 1 & & & \\
\hline $\begin{array}{l}\text { Myrtaceidites mesonesus Cookson \& Pike } \\
1954\end{array}$ & & 1 & 38 & 8 & 17 & 11 \\
\hline Tricolporates & & & & & & \\
\hline Asteraceae spp. & 2 & & & & 1 & \\
\hline Ericipites longisulcatus Wodehouse 1933 & 1 & & & & & \\
\hline Ligulifloridites $\mathrm{sp}$ & & & & & & 1 \\
\hline $\begin{array}{l}\text { Palaeocoprosmadites zelandiae Pocknall } \\
1982\end{array}$ & 1 & & 29 & 118 & 38 & 54 \\
\hline $\begin{array}{l}\text { Rhoipites alveolatus (Couper 1953) Pocknall } \\
\text { \& Crosbie } 1982\end{array}$ & 5 & & & & 2 & \\
\hline Rhoipites spp. & & & 2 & 1 & 5 & \\
\hline Tricolporites scabratus Harris 1965 & 1 & & & & 10 & \\
\hline Tricolporites spp. & & 1 & & & 6 & 2 \\
\hline Tubulifloridites pleistocenicus Martin 1973 & & 2 & & & & \\
\hline Tubulifloridites simplis Martin 1973 & & 1 & & & & \\
\hline Tubuliflorae spp. & & 3 & & & & \\
\hline Monoporates & & & & & & \\
\hline Graminidites media Cookson 1947 & 1 & & 1 & & & 8 \\
\hline $\begin{array}{l}\text { Lateropora glabra Pocknall \& Mildenhall } \\
1984\end{array}$ & & 2 & & & & \\
\hline $\begin{array}{l}\text { Sparganiaceaepollenites barungensis } \\
\text { Harris } 1972\end{array}$ & & & & 6 & 2 & \\
\hline $\begin{array}{l}\text { Sparganiaceaepollenites sphericus (Couper } \\
\text { 1960) Mild. in Mild. \& Crosbie } 1979\end{array}$ & & 2 & 1 & & & \\
\hline Triporates & & & & & & \\
\hline $\begin{array}{l}\text { Myricipites harrisii (Couper 1953) Dutta \& } \\
\text { Sah } 1970\end{array}$ & & 9 & 57 & 15 & 13 & 1 \\
\hline Proteacidites minimus Couper 1954 & 1 & 2 & & & & \\
\hline Proteaceae spp. & & & 4 & 4 & & 2 \\
\hline Triorites minor Couper 1953 & & 3 & & & 1 & \\
\hline Triorites spp. & & 7 & & & 4 & \\
\hline Polyporates & & & & & & \\
\hline 1986 & 1 & 2 & 1 & & & \\
\hline Parsonsidites psilatus Couper 1960 & & & & & & 1 \\
\hline
\end{tabular}


$\underline{\text { Mauriceville section - taxonomic list }}$

\begin{tabular}{|l|c|c|c|}
\hline Sample number & KH1307 & KH1306 & KH1309 \\
\hline Number of slides observed & 1 & 5 & 1 \\
\hline Total count & 250 & 250 & 250 \\
\hline
\end{tabular}

\begin{tabular}{|c|c|c|c|}
\hline Taxonomic Name & & Count & \\
\hline SPORES & & & \\
\hline Monolete & & & \\
\hline Monoletes & 24 & 30 & 19 \\
\hline $\begin{array}{l}\text { Polypodiisporites inangahuensis (Couper 1953) Potonie } \\
1956\end{array}$ & & 7 & 2 \\
\hline $\begin{array}{l}\text { Polypodiisporites variscabratus Mildenhall \& Pocknall } \\
1989\end{array}$ & 4 & 17 & 13 \\
\hline $\begin{array}{l}\text { Polypodiisporites minimus (Couper 1960) Khan \& } \\
\text { Martin } 1971\end{array}$ & & 1 & \\
\hline Polypodiisporites radiatus Pocknall \& Mildenhall 1984 & 2 & 9 & 4 \\
\hline Polypodiisporites spp. & 3 & 5 & 9 \\
\hline Trilete & & & \\
\hline Cyathea type & 82 & 103 & 55 \\
\hline Baculatisporites spp. & & & 5 \\
\hline Foveotriletes lacunosus Partridge 1973 & & & 1 \\
\hline Foveotriletes verrucosus Pocknall \& Mildenhall 1984 & & & 1 \\
\hline $\begin{array}{l}\text { Cibotiidites tuberculiformis (Cookson 1947) Skarby } \\
1974\end{array}$ & 2 & 11 & 23 \\
\hline $\begin{array}{l}\text { Polypodiaceoisporites papuanus (Khan 1976) Pocknall } \\
1985\end{array}$ & & & 5 \\
\hline $\begin{array}{l}\text { Polypodiaceoisporites tumulatus Partridge in Stover \& } \\
\text { Partridge } 1973\end{array}$ & & 1 & \\
\hline POLLEN & & & \\
\hline Saccites & & & \\
\hline $\begin{array}{l}\text { Dacrydiumites praecupressinoides (Couper 1953) } \\
\text { Truswell } 1983\end{array}$ & 25 & 6 & 36 \\
\hline $\begin{array}{l}\text { Microalatidites paleogenicus (Cookson \& Pike 1954) } \\
\text { Mildenhall \& Pocknall } 1989\end{array}$ & & & 2 \\
\hline Pinus spp. & & 3 & \\
\hline Podocarpus spp. & 7 & 6 & 8 \\
\hline Dacrycarpites australiensis Cookson \& Pike 1953 & & & 1 \\
\hline Monosulcates & & & \\
\hline Arecipites cf. Rhopalostylis sapida Wendl. \& Drude & & 8 & \\
\hline Arecipites spp. & & 1 & \\
\hline Liliacidites variegatus Couper 1953 & & 15 & 11 \\
\hline Monogemmites gemmatus (Couper 1960) Krutzsch 1970 & & 1 & 3 \\
\hline Tricolpates & & & \\
\hline Cranwellia striata (Couper 1953) Srivastava 1966 & & & 1 \\
\hline Stephanocolpates & & & \\
\hline $\begin{array}{l}\text { Nothofagidites cranwelliae (Couper 1953) Mildenhall \& } \\
\text { Pocknall } 1989\end{array}$ & & & 3 \\
\hline
\end{tabular}




\begin{tabular}{|l|c|c|c|}
\hline Nothofagus fusca type & 1 & & 2 \\
\hline Nothofagidites matauraensis (Couper 1953) Hekel 1972 & & & 5 \\
\hline $\begin{array}{l}\text { Nothofagidites spinosus (Couper 1960) Mildenhall \& } \\
\text { Pocknall 1989 }\end{array}$ & & & 5 \\
\hline Nothofagidites undifferentiated & 5 & 8 & 25 \\
\hline Syncolporates & & & \\
\hline Myrtaceidites mesonesus Cookson \& Pike 1954 & & & \\
\hline Tricolporates & 4 & & 2 \\
\hline Asteraceae spp. & 13 & & \\
\hline Ligulifloridites sp. & 5 & & 2 \\
\hline Palaeocoprosmadites zelandiae Pocknall 1982 & 3 & & \\
\hline $\begin{array}{l}\text { Rhoipites alveolatus (Couper 1953) Pocknall \& Crosbie } \\
\text { 1982 }\end{array}$ & 4 & & \\
\hline Rhoipites spp. & & 5 & \\
\hline Tricolporites spp. & 1 & 3 & \\
\hline Tubulifloridites simplis Martin 1973 & & & \\
\hline Tubuliflorae spp. & 62 & 1 & \\
\hline Monoporates & & & \\
\hline Graminidites media Cookson 1947 & & 6 & \\
\hline Triporates & & & 2 \\
\hline Myricipites harrisii (Couper 1953) Dutta \& Sah 1970 & & & \\
\hline Proteaceae spp. & & & \\
\hline Triorites minor Couper 1953 & & & \\
\hline Stephanoporates & & & \\
\hline $\begin{array}{l}\text { Haloragacidites amolosus Partridge in Stover \& } \\
\text { Partridge 1973 }\end{array}$ & & & \\
\hline Polyporates & & & \\
\hline Malvacearumpollis mannanensis Wood 1986 & & \\
\hline Parsonsidites psilatus Couper 1960 & & & \\
\hline
\end{tabular}


Mt Bruce section - taxonomic list

\begin{tabular}{|l|c|}
\hline Sample & Wells (1985) \\
\hline Number of slides observed & 1 \\
\hline Total count & 250 \\
\hline
\end{tabular}

\begin{tabular}{|l|c|}
\hline Taxonomic Name & Count \\
\hline SPORES & \\
\hline Monolete & 15 \\
\hline Monoletes & 2 \\
\hline Polypodiisporites variscabratus Mildenhall \& Pocknall 1989 & 3 \\
\hline Polypodiisporites minimus (Couper 1960) Khan \& Martin 1971 & 7 \\
\hline Polypodiisporites spp. & \\
\hline Trilete & 3 \\
\hline Cyathea type & 1 \\
\hline Baculatisporites spp. & 2 \\
\hline Polypodiaceoisporites tumulatus Partridge in Stover \& Partridge 1973 & \\
\hline POLLEN & \\
\hline Saccites & 3 \\
\hline $\begin{array}{l}\text { Microalatidites paleogenicus (Cookson \& Pike 1954) Mildenhall \& } \\
\text { Pocknall 1989 }\end{array}$ & \\
\hline Apiculati & 1 \\
\hline Araucariacites australis Cookson 1947 & \\
\hline Monosulcates & 7 \\
\hline Arecipites otagoensis (Couper 1960) Mildenhall \& Pocknall 1989 & 3 \\
\hline Monogemmites gemmatus (Couper 1960) Krutzsch 1970 & 3 \\
\hline Stephanocolpates & \\
\hline Nothofagidites cranwelliae (Couper 1953) Mildenhall \& Pocknall 1989 & 13 \\
\hline Nothofagidites lachlaniae (Couper 1953) Pocknall \& Mildenhall 1984 & 8 \\
\hline Nothofagidites undifferentiated & \\
\hline Polycolpates & \\
\hline Glencopollis ornatus Pocknall \& Mildenhall 1984 & \\
\hline Syncolporates & \\
\hline Myrtaceidites mesonesus Cookson \& Pike 1954 & \\
\hline Tricolporates & \\
\hline Bombacacidites bombaxoides Couper 1960 & \\
\hline Palaeocoprosmadites zelandiae Pocknall 1982 & \\
\hline Rhoipites spp. & \\
\hline Tubulifloridites pleistocenicus Martin 1973 & \\
\hline Monoporates & \\
\hline Sparganiaceaepollenites barungensis Harris 1972 & \\
\hline Triporates & \\
\hline Myricipites harrisii (Couper 1953) Dutta \& Sah 1970 & \\
\hline Proteaceae spp. & \\
\hline
\end{tabular}




\begin{tabular}{|l|c|}
\hline Stephanoporates & \\
\hline Malvacipollis subtilis Stover in Stover \& Partridge 1973 & 3 \\
\hline Polyporates & \\
\hline Cyperaceaepollis neogenicus Krutzsch 1970 & 2 \\
\hline
\end{tabular}


Appendix 1.3. - Pollen plates

Podocarp-hardwood pollen

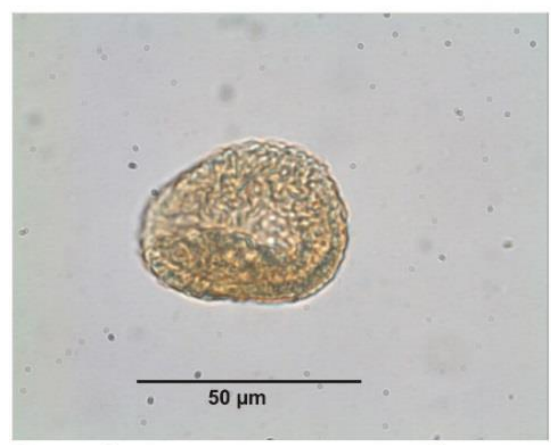

Dacrydiumites praecupressinoides

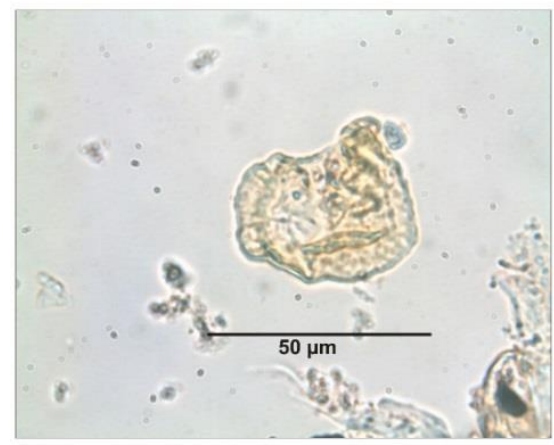

Microalatidites paleogenicus

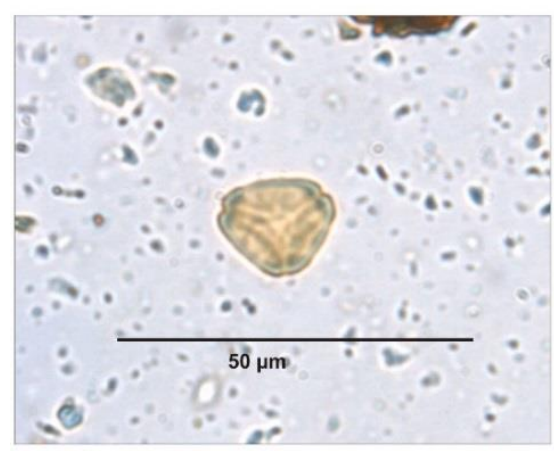

Myrtaceidites mesonesus

Beech pollen

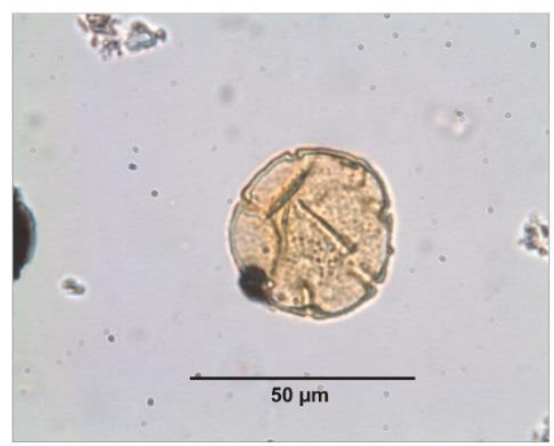

Nothofagidites lachlaniae
Plate 1

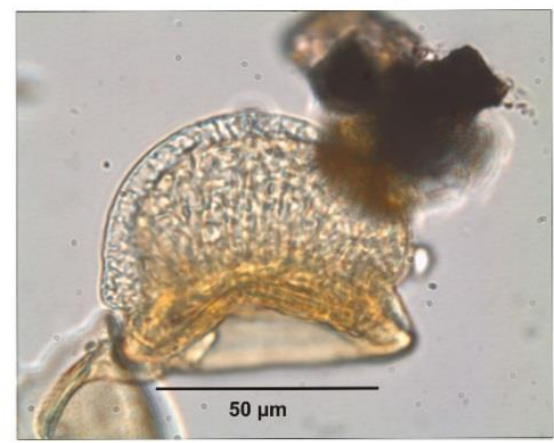

Podocarpus spp.

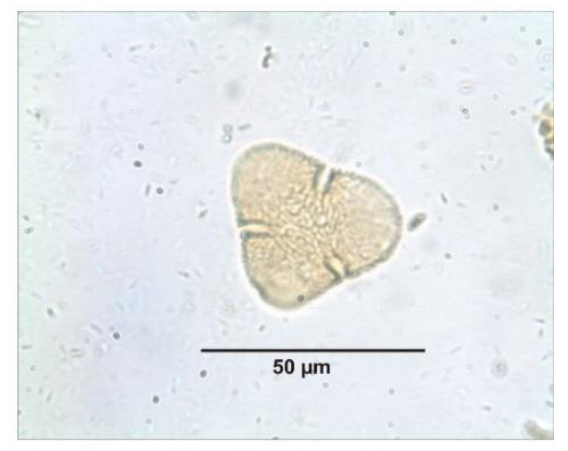

Bombacacidites bombaxoides

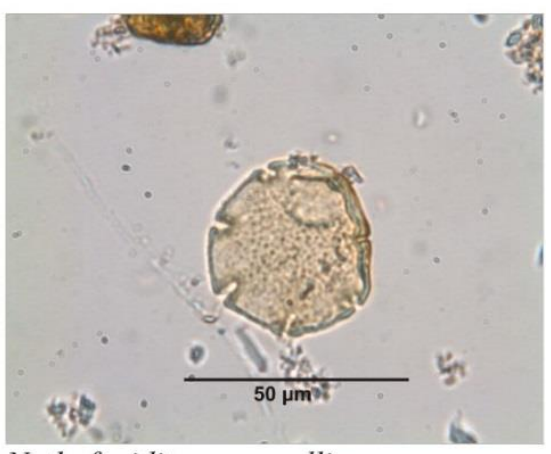

Nothofagidites cranwelliae 
Beech pollen

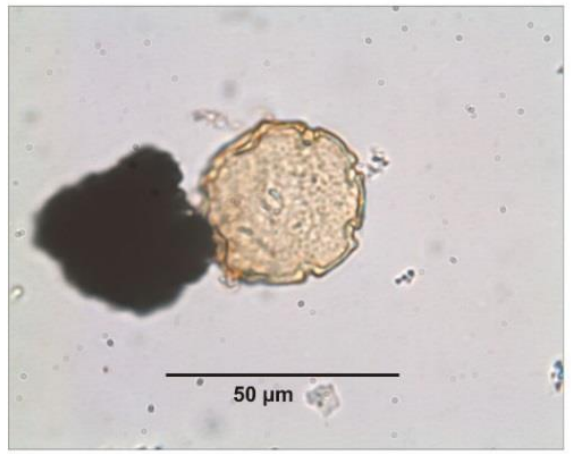

Nothofagidites fusca type

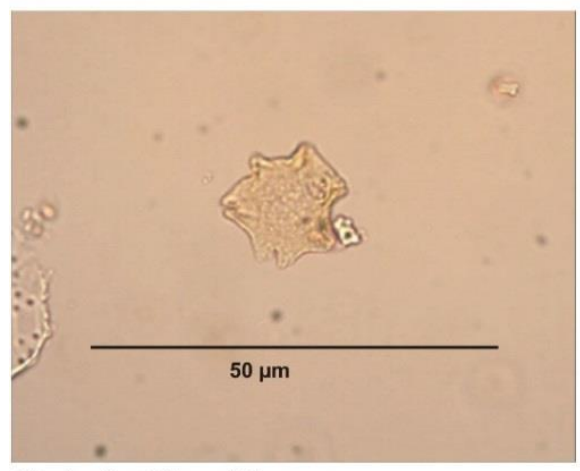

Nothofagidites falcatus

Arboreal swamp pollen

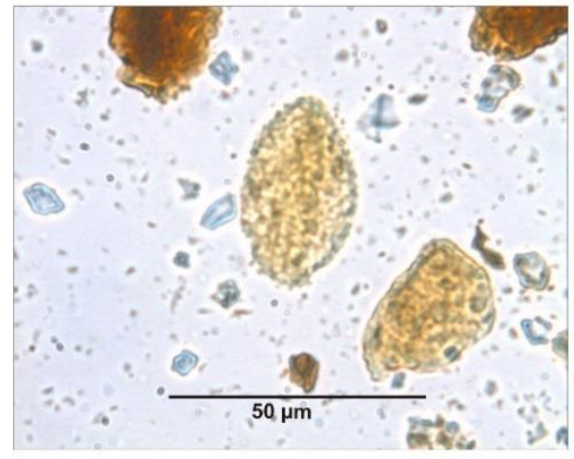

Liliacidites variegatus

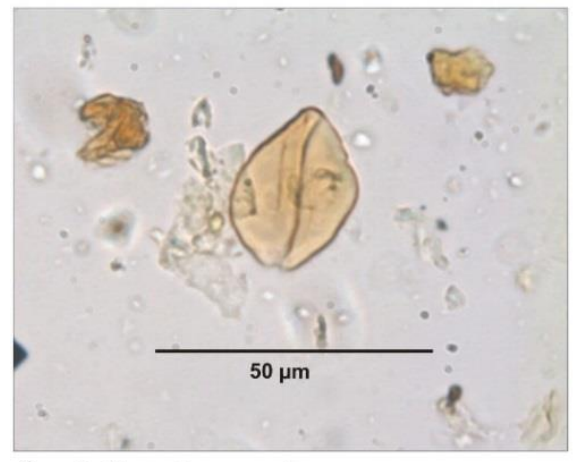

Arecipites otagoensis
Plate 2

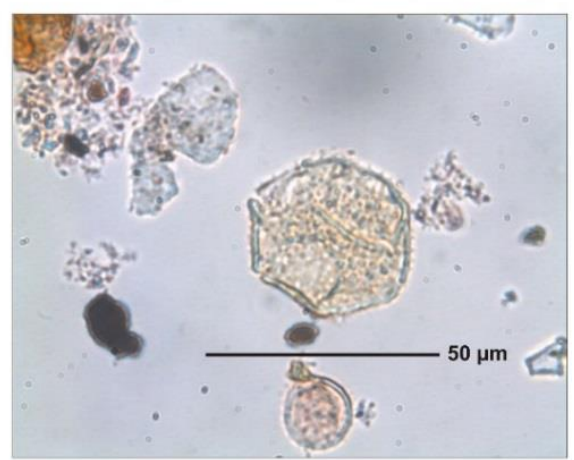

Nothofagidites spinosus

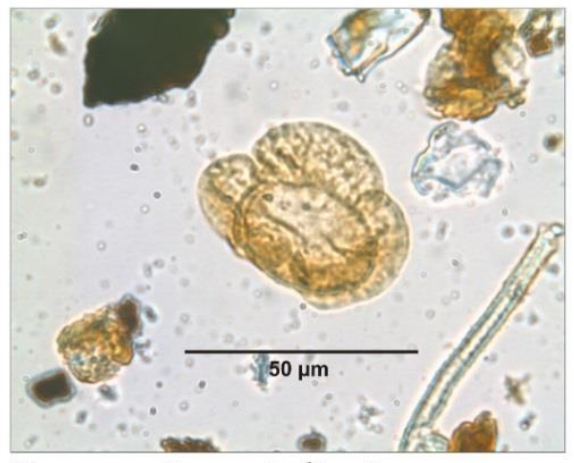

Dacrycarpites australiensis

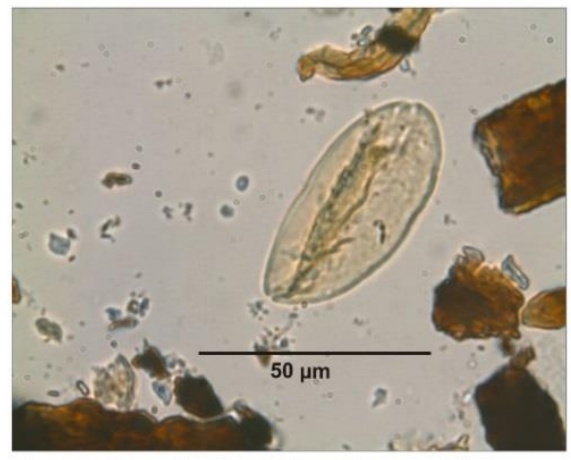

Arecipites $\mathrm{cf}$. Rhopalostylis sapida 
Other arboreal pollen

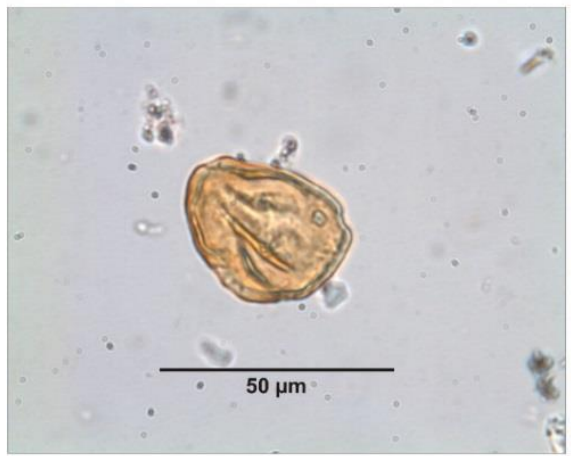

Myricipites harrisii

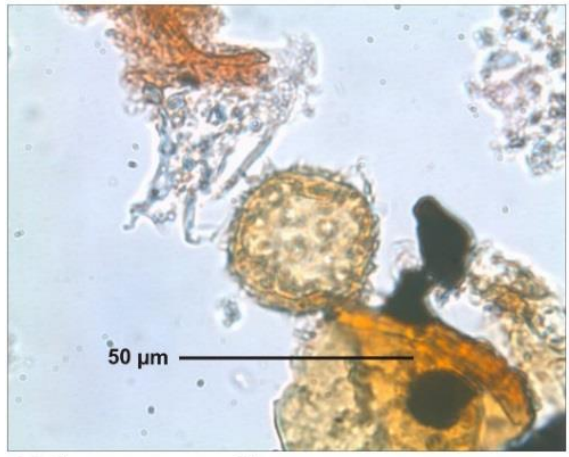

Malvacearumpollis mannanensis

$\underline{\text { Shrub pollen }}$

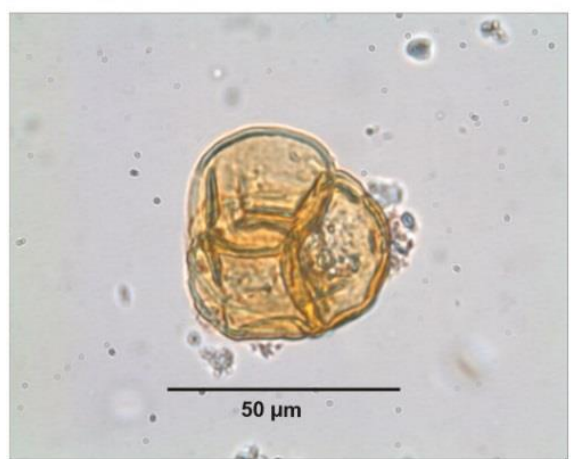

Ericipites longisulcatus

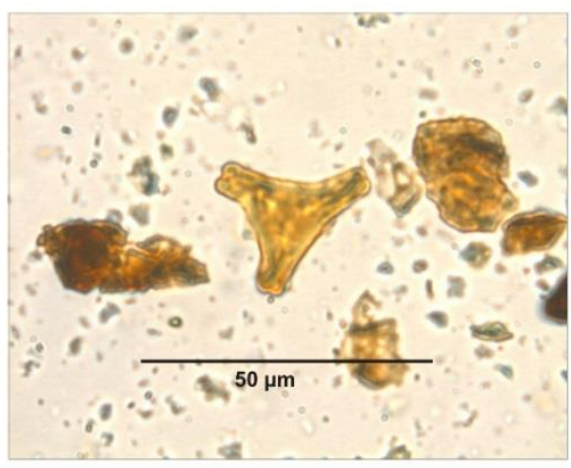

Gothanipollis gothani $\underline{\text { Plate } 3}$

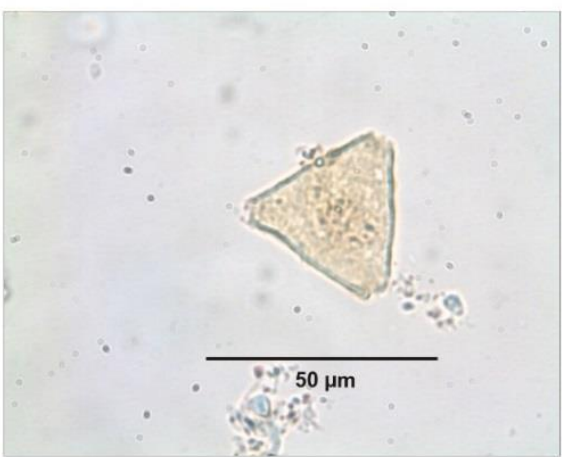

Proteaceae spp.

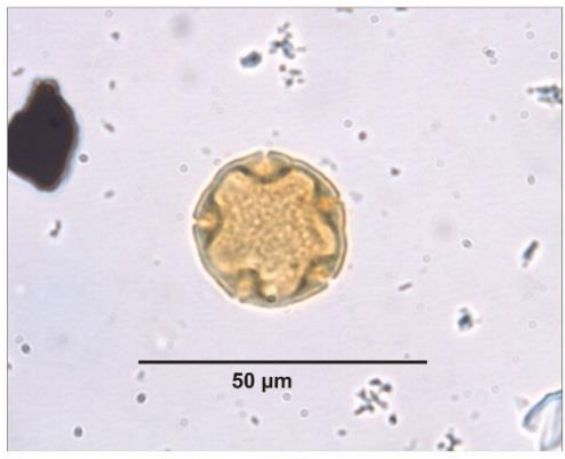

Reevesiapollis reticulatus

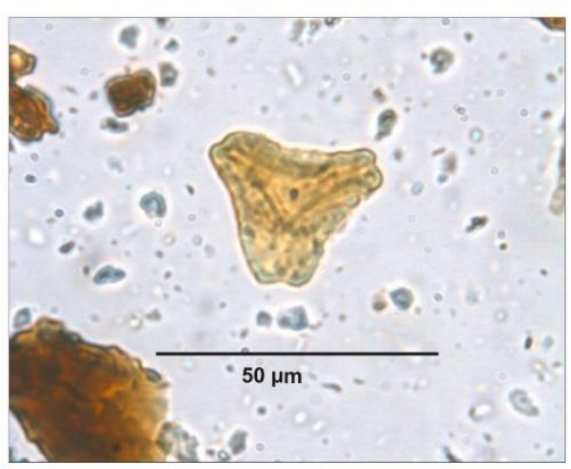

Gothanipollis bassensis

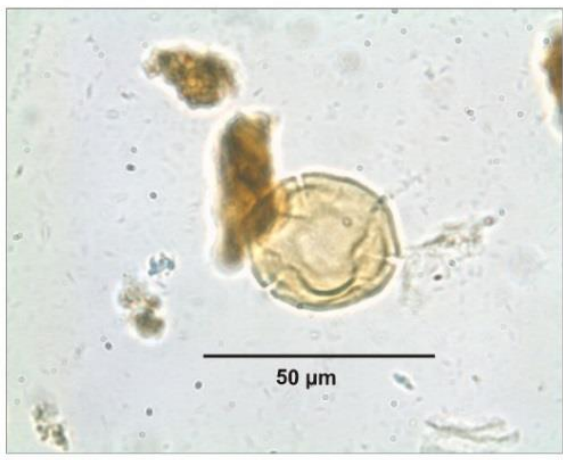

Palaeocoprosmadites zelandiae 
$\underline{\text { Shrub pollen }}$

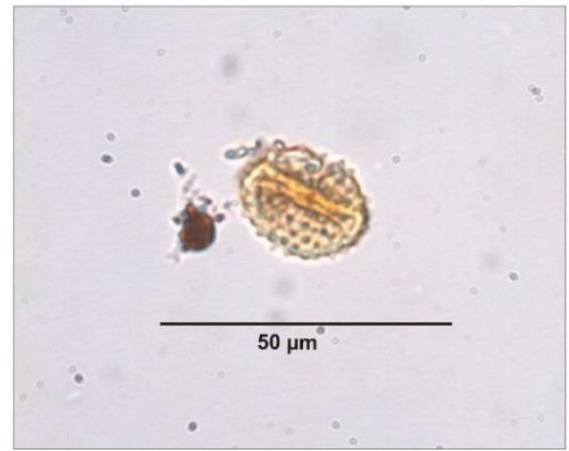

Tubulifloridites pleistocenicus

Herb pollen

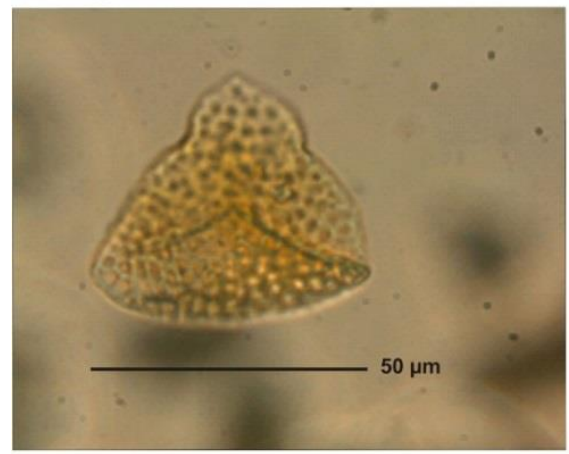

Foveotriletes lacunosus

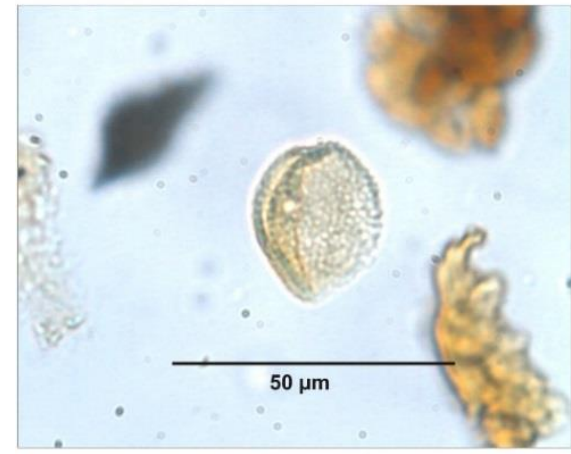

Sparganiaceaepollenites barungensis

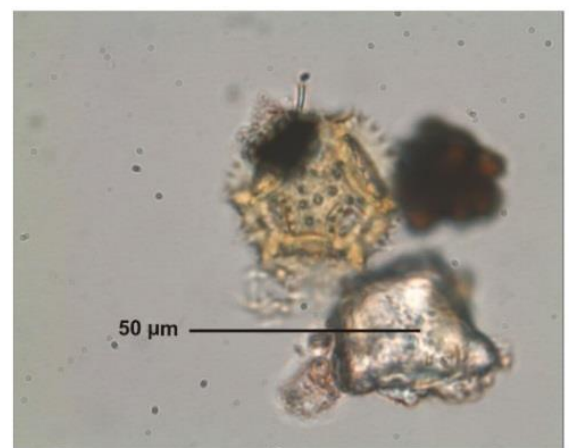

Ligulifloridites sp.
Grass-like pollen

$\underline{\text { Plate } 4}$

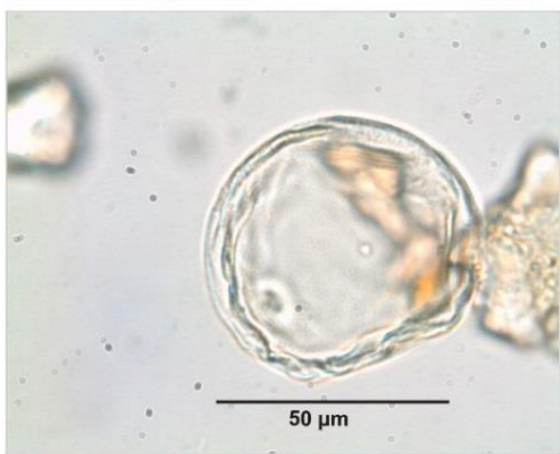

Graminidites media

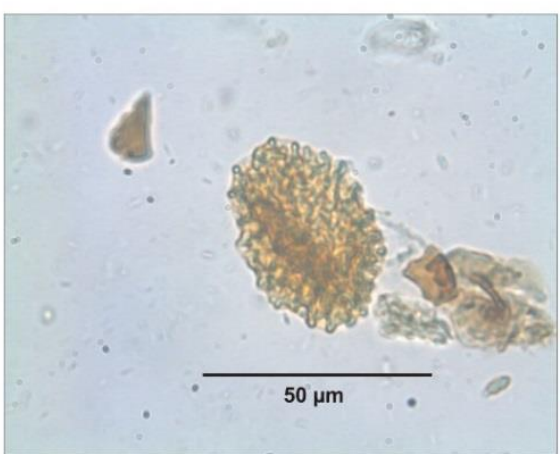

Monogemmites gemmatus

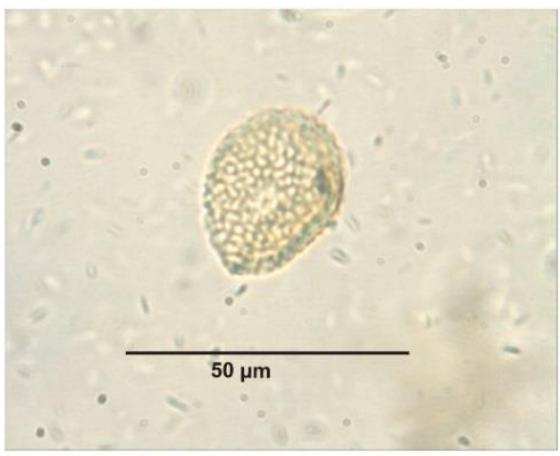

Sparganiaceaepollenites sphericus

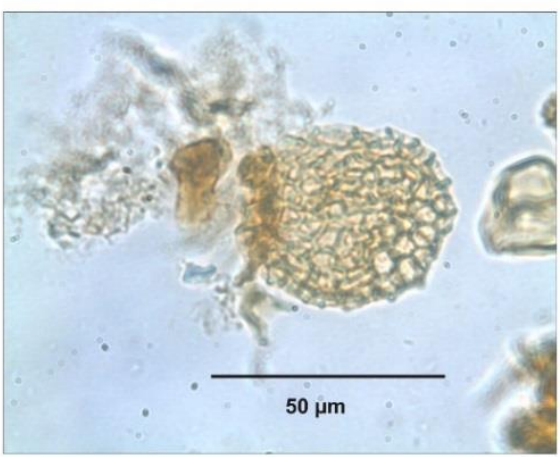

Glencopollis ornatus 
Ground fern spores

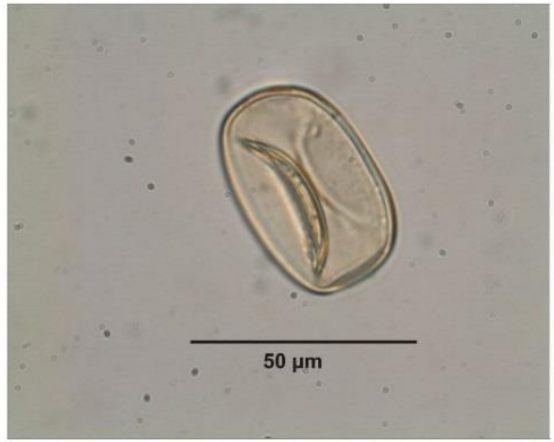

Monolete

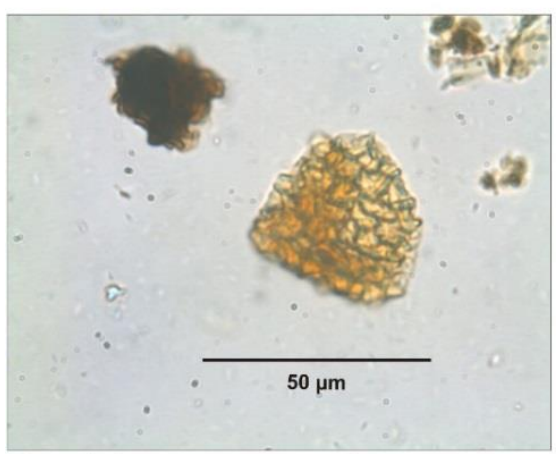

Rugulatisporites cowrensis

$\underline{\text { Tree fern spores }}$

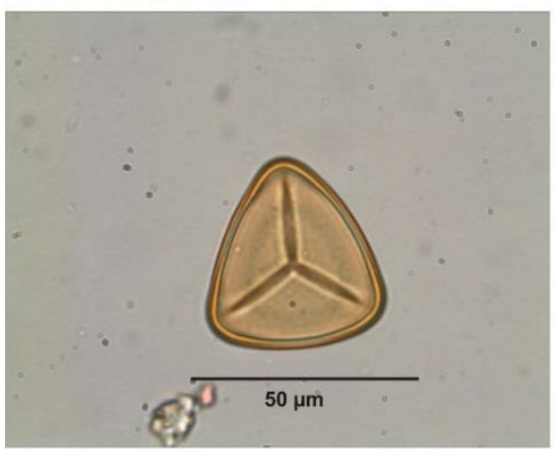

Cyathea type

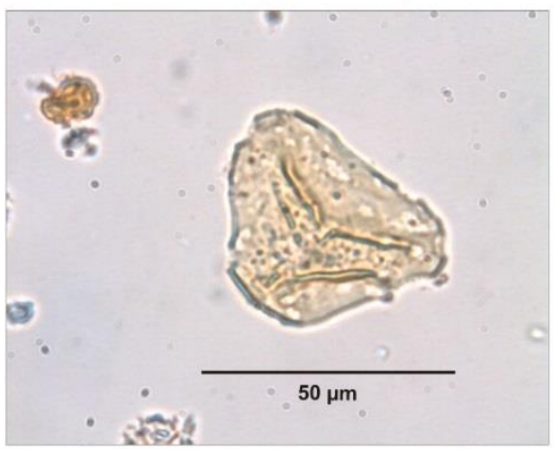

Foveotriletes verrucosus $\underline{\text { Plate } 5}$

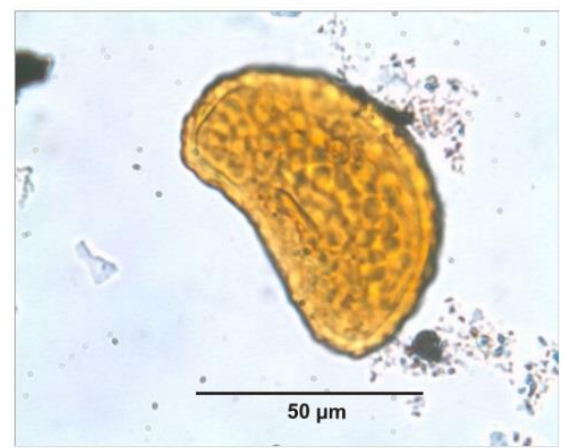

Polypodiisporites spp.

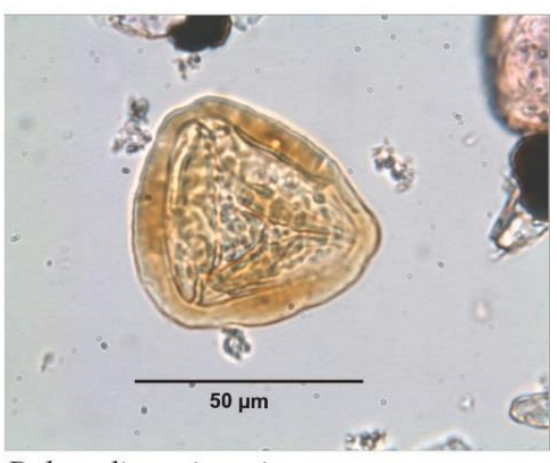

Polypodiaceoisporites papuanus

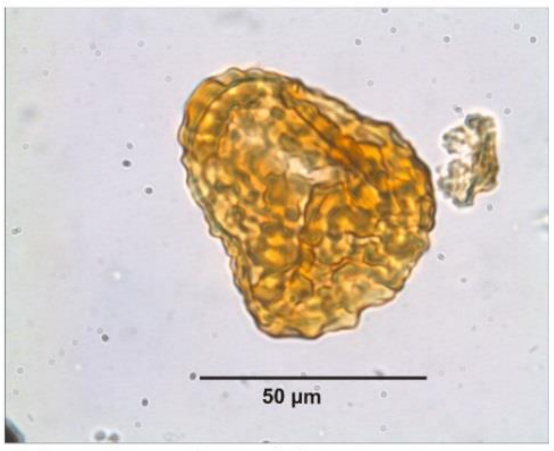

Cibotiidites tuberculiformis

\section{Climber and epiphyte pollen}

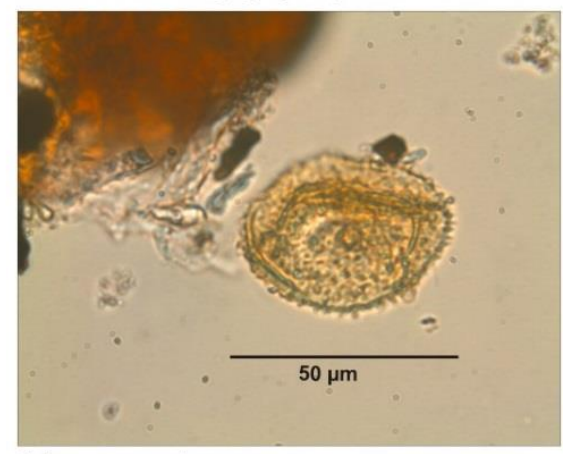

Monogemmites sp. 
Pollen with an unknown affinity

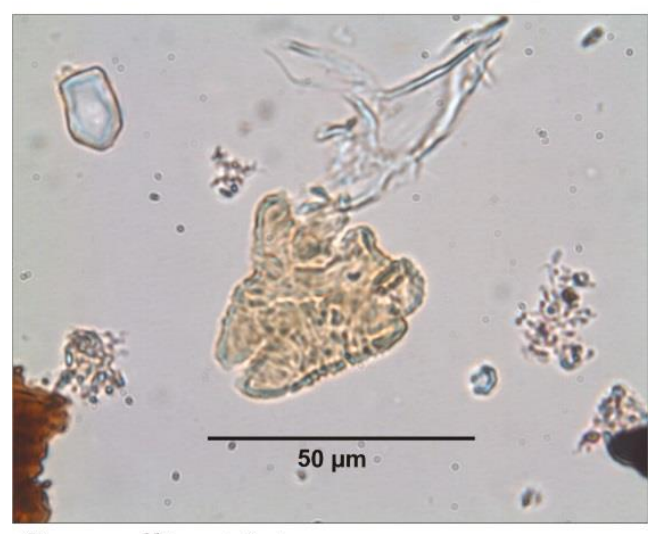

Cranwellia striata
Plate 6

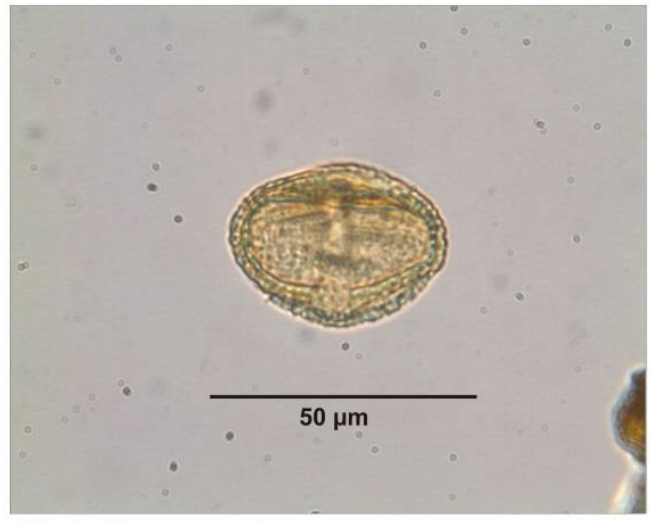

Rhoipites alveolatus 
Appendix 2.1. - Fission-track processing technique

To ensure the sample was free of any contaminants, the sample was cleaned under running cold water using a standard hand and nail scrubbing brush. It was then placed in a labelled $80.0 \times 60.0 \mathrm{~cm}$ rectangular foil tray and left to dry overnight in an oven set at $50^{\circ} \mathrm{C}$.

The sample was cut into approximate $4.0 \times 4.0 \times 2.5 \mathrm{~cm}$ pieces. The saw was used to minimise the loss of sample prior to crushing. The sample was left to dry overnight in an oven set at $50^{\circ} \mathrm{C}$.

1. The dry sample was crushed using the Boyd crusher, first using a plate width of approximately $2.5 \mathrm{~cm}$. The plate width was then reduced to $0.2 \mathrm{~cm}$ (minimum plate width) where the sample was crushed a further $6-10$ times. Between every 1-2 crushes, the sample was sieved using a $250 \mu \mathrm{m}$ sieve cloth. The crushing ceased when a sufficient amount (approximately $1 \mathrm{~kg}$ ) of $<250 \mu \mathrm{m}$ sample was collected. This material was packed in plastic bags and reserved for further processing. The remaining $>250 \mu \mathrm{m}$ material was collected, packed in plastic bags and stored for further processing if necessary.

2. The $<250 \mu \mathrm{m}$ portion was passed across a Wilfley Table to separate the heavy minerals from the lighter. The three sub-samples containing the heaviest mineral separations were collected and stored for further processing. The remaining light mineral separations were discarded.

3. The sub-sample was passed through the Frantz Isodynamic magnetic separator to separate the minerals according to magnetic sensitivity. Both the slope and tilt angles of the tray were set to $10^{\circ}$, while the current was set to $0.6 \mathrm{~A}$ and voltage to approximately $40 \mathrm{~V}$. At these settings, non-magnetic minerals such as apatite and zircon split from the magnetic minerals.

If there was a large non-magnetic portion collected with these settings, the portion was placed through the Frantz again, this time with a current of $1.0 \mathrm{~A}$ and voltage of approximately $70 \mathrm{~V}$. The second non-magnetic portion was set aside for further processing.

4. The non-magnetic sample was placed through a heavy liquid solution of methylene iodide with a density of $3.1 \mathrm{~g} / \mathrm{cm}^{3}$. 


\section{Heavy liquid technique}

- $100 \mathrm{mls}$ of $3.1 \mathrm{~g} / \mathrm{cm}^{3}$ methylene iodide was prepared by diluting $3.3 \mathrm{~g} / \mathrm{cm}^{3}$ methylene iodide with acetone to the required density.

- About $40 \mathrm{mls}$ of methylene iodide was poured into a separating funnel.

- The non-magnetic fraction was added to the solution and stirred using a glass stirring rod.

- An extra $10 \mathrm{mls}$ of methylene iodide was funnelled onto the inner walls of the separating funnel to remove any sample adhering to the sides.

- The sample was left to settle at room temperature until there were no visible grains descending within the liquid (approximately 20 minutes). In this solution, the heavy minerals (density $>3.1 \mathrm{~g} / \mathrm{cm}^{3}$ ) such as zircon (density $4.60 \mathrm{~g} / \mathrm{cm}^{3}$ ) and apatite (density $3.21 \mathrm{~g} / \mathrm{cm}^{3}$ ) sank.

- The heavy mineral fraction was removed from the funnel by turning the stopcock and collected onto filter paper.

- The sample was washed thoroughly using acetone and left to air dry under an inverted beaker for 30 minutes.

- The remaining light mineral fraction was filtered, cleaned, air dried, packed into plastic bags and stored.

5. The heavy mineral portion was filtered through another solution of methylene iodide, this time with a density of $3.3 \mathrm{~g} / \mathrm{cm}^{3}$.

The separation was carried out as in step 6, with a settling time of 30 minutes. In this solution the minerals with a density $>3.3 \mathrm{~g} / \mathrm{cm}^{3}$ sank (such as zircon) while the minerals with a density $<3.3 \mathrm{~g} / \mathrm{cm}^{3}$ (apatite) remained buoyant. Both the heavy and light fractions were removed from the separating funnel, washed with acetone and left to dry as in step 5. Each fraction was inspected under a binocular microscope to ensure a sufficient number (approximately 30 crystals or more) of zircon and apatite crystals were present in the samples.

6. Pyrite was dissolved from some $>3.3 \mathrm{~g} / \mathrm{cm}^{3}$ fractions by placing the samples in a $50 \mathrm{ml}$ glass beaker of aqua regia (3:1 concentrated hydrochloric and nitric acid) overnight. Once the pyrite was dissolved, the supernatant was decanted and the residue rinsed with distilled water. The residue was cleaned with alcohol. 
7. The apatite $\left(<3.3 \mathrm{~g} / \mathrm{cm}^{3}\right)$ sample was mounted onto circular glass mounts (diameter of $2.0 \mathrm{~cm}$ ) using epoxy resin. $2-3$ (depending on the sample quantity) apatite-epoxy mounts were made per sample.

Apatite mounting technique

- The glossy side of each mount was labelled.

- The apatite sample was poured evenly over the etched side of each mount.

- Two drops of the epoxy resin were placed over the sample.

- Using a blunt metal rod, the epoxy resin and sample were mixed and spread over the mount until the grains were uniformly distributed. The grain distribution was inspected under a binocular microscope.

- The mounts were placed on a hot plate set at $52^{\circ} \mathrm{C}$ and left to harden overnight.

8. The zircon $\left(>3.3 \mathrm{~g} / \mathrm{cm}^{3}\right)$ sample was mounted into circular teflon sheets (diameter of $1.5 \mathrm{~cm}$ ) and subsequently fixed onto circular glass mounts (diameter of $2.0 \mathrm{~cm}$ ). Two zircon-teflon mounts were made per sample.

Zircon mounting technique

- Several standard rectangular glass slides were placed on a hotplate set at $495^{\circ} \mathrm{C}$ and left for 1 minute, or until warm. Clean glass slides were used for each mount.

- $1 / 3-1 / 2$ of the zircon fraction was placed on the top of one slide. Using a blunt steel rod, the sample was spread evenly over a small circular area $(<$ $1.5 \mathrm{~cm}$ diameter) of the slide.

- A teflon sheet was placed on the sample.

- A second hot glass slide was placed over the teflon sheet.

- Using tweezers, the glass slide was firmly held on top of the teflon sheet for $15-20 \mathrm{~s}$. This ensured the teflon was flexible and took up the crystals.

- Using tweezers, the glass slides with the teflon mount between were removed from the hotplate and left to cool for approximately 1 minute.

- Once cool, the teflon mount was removed from the glass slides. Using a diamond tipped pen the sample number was etched onto the back side of the mount (side containing no crystals).

- Double-sided tape was stuck to the etched side of the mount. The mount was then taped to the frosty side of a circular glass mount. 
9. The zircon-teflon and apatite-epoxy mounts were ground to expose the internal surface of the crystals ( $4 \pi$ geometry) using strips of wet 600,800 and 1200 grit sandpaper.

10. The zircon-teflon and apatite-epoxy mounts were polished using two 12-inch (30 $\mathrm{cm})$ rotating lap wheels. Samples were polished using 3 and 1 micron diamond paste.

11. The apatite-epoxy mounts were etched in $5.5 \mathrm{~N}$ nitric acid $\left(\mathrm{HNO}_{3}\right)$ enchant for $20.0 \mathrm{~s}$ at $21^{\circ} \mathrm{C}$ to enlarge the fission tracks along the crystals exposed internal surface. They were rinsed for a minimum of 0.5 hours to remove any remaining acid.

12. The zircon-teflon mounts were etched in a $(\mathrm{KOH}-\mathrm{NaOH})$ eutectic melt at about $214^{\circ} \mathrm{C}$ for $64 \mathrm{hrs}$ to enlarge the fission tracks along the crystals exposed internal surface.

13. The etched apatite-epoxy and zircon-teflon mounts were cleaned in ethanol and attached to an external detector (a thin low-uranium $(<5 \mathrm{ppb})$ sheet of muscovite mica) before being sent to the nuclear reactor. For every eight mounts, a standard glass dosimeter (zeta CN1 for zircon and zeta CN5 for apatite) with muscovite attached to the side was wrapped in tape. The mounts were stacked inside a plastic tube (separate tubes for both the apatite and zircon mounts) with the corresponding dosimeter between every eight mounts

14. The packed apatite and zircon mounts were sent to the Radiation Center, Oregon State University, USA, to be irradiated. Here, the mounts were bombarded with neutrons in order to induce new ${ }^{235} \mathrm{U}$ fission tracks. Following irradiation, the mounts were held at Oregon State University, USA, until radioactively cool.

15. Once returned the external detectors from both the mounts and glass dosimeter were etched in $40 \% \mathrm{HF}$ acid for 45 minutes at room temperature.

16. The apatite and zircon fission-tracks in both the mounts and thermal detectors were counted by Prof Diane Seward using a Zeiss Mm1 microscope. The apatite and micas were counted with a $\mathrm{x} 1000$ dry objective and the zircons with a $\mathrm{x}$ 1000 oil objective. 
Appendix 2.2. - Fission-track data

$\underline{\text { KH1201 - Apatite plots }}$

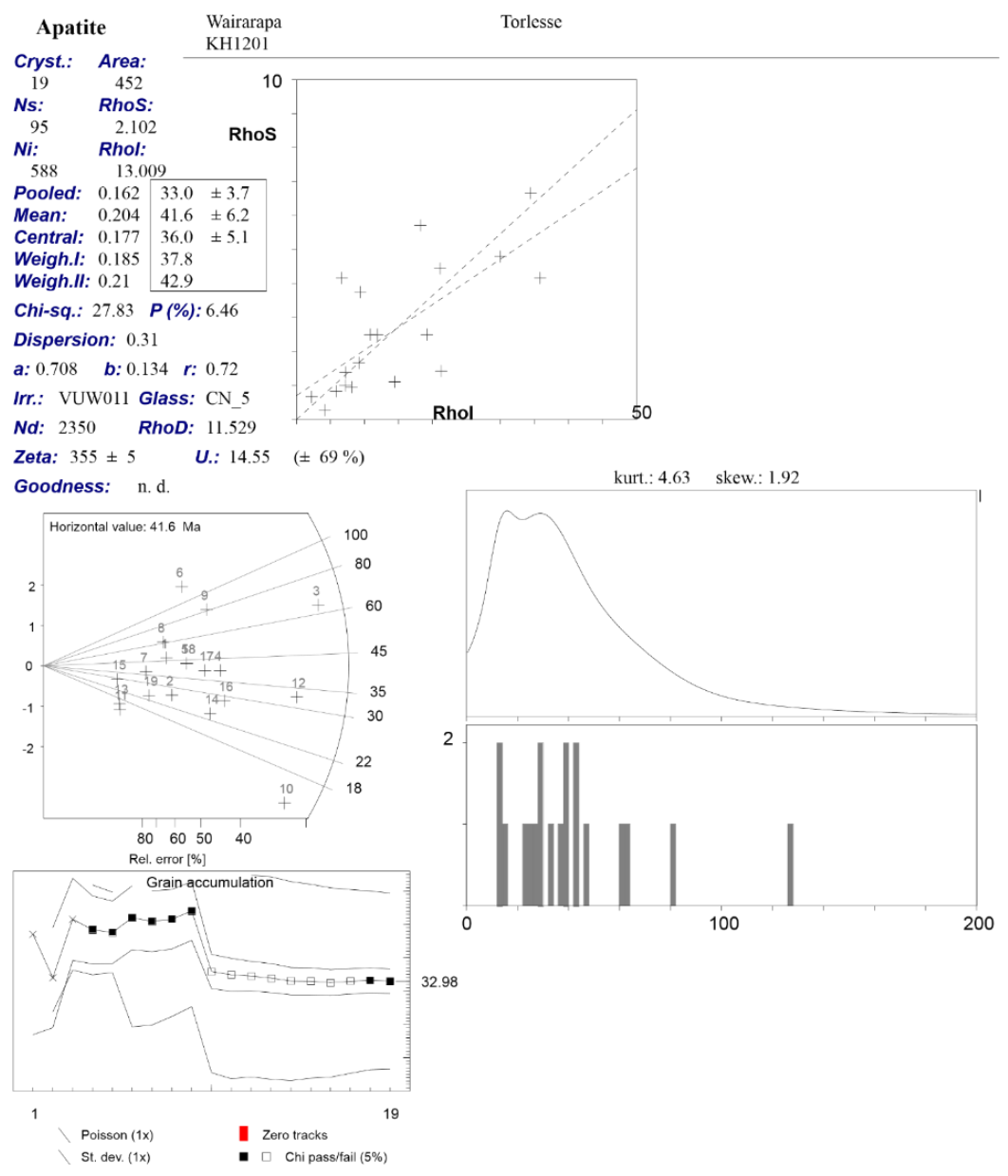

\section{$\underline{\text { KH1201 - Apatite data table }}$}

Wairarapa KH1201 Torlesse

19 Apatite crystals Sum. Ns: 95 Sum. Ni: 588

Zeta: $355+-5$ Micr. grid.: 100

Glass:CN_5 Irrad. code: VUW011 RhoD: 11.529 Nd:2350

\begin{tabular}{rrrrrrrrr} 
Cryst & $N s$ & $N i$ & A RhoS & Rhol & Age & $+-1 s$ & Uran. & \\
- \hdashline 1 & 3 & 13 & 12 & 2.500 & 10.833 & 47.05 & 30.16 & 10.807 \\
2 & 3 & 23 & 12 & 2.500 & 19.167 & 26.64 & 16.36 & 19.120 \\
3 & 16 & 51 & 28 & 5.714 & 18.214 & 63.88 & 18.37 & 18.169 \\
4 & 6 & 31 & 9 & 6.667 & 34.444 & 39.49 & 17.64 & 34.360 \\
5 & 4 & 19 & 9 & 4.444 & 21.111 & 42.94 & 23.65 & 21.059 \\
6 & 5 & 8 & 12 & 4.167 & 6.667 & 126.65 & 72.27 & 6.650 \\
7 & 2 & 11 & 12 & 1.667 & 9.167 & 37.10 & 28.53 & 9.144 \\
8 & 3 & 10 & 45 & .667 & 2.222 & 61.10 & 40.25 & 2.217 \\
9 & 6 & 15 & 16 & 3.750 & 9.375 & 81.34 & 39.34 & 9.352 \\
10 & 10 & 149 & 70 & 1.429 & 21.286 & 13.72 & 4.49 & 21.233 \\
11 & 1 & 15 & 36 & .278 & 4.167 & 13.63 & 14.08 & 4.156 \\
12 & 12 & 75 & 25 & 4.800 & 30.000 & 32.66 & 10.19 & 29.926 \\
13 & 1 & 13 & 9 & 1.111 & 14.444 & 15.72 & 16.32 & 14.409 \\
14 & 5 & 43 & 12 & 4.167 & 35.833 & 23.75 & 11.24 & 35.745 \\
15 & 1 & 7 & 12 & .833 & 5.833 & 29.17 & 31.19 & 5.819 \\
16 & 6 & 43 & 60 & 1.000 & 7.167 & 28.49 & 12.44 & 7.149 \\
17 & 5 & 26 & 36 & 1.389 & 7.222 & 39.23 & 19.18 & 7.204 \\
18 & 4 & 19 & 16 & 2.500 & 11.875 & 42.94 & 23.65 & 11.846 \\
19 & 2 & 17 & 21 & .952 & 8.095 & 24.03 & 17.97 & 8.075
\end{tabular}




\section{$\underline{\text { KH1201 - Zircon plots }}$}

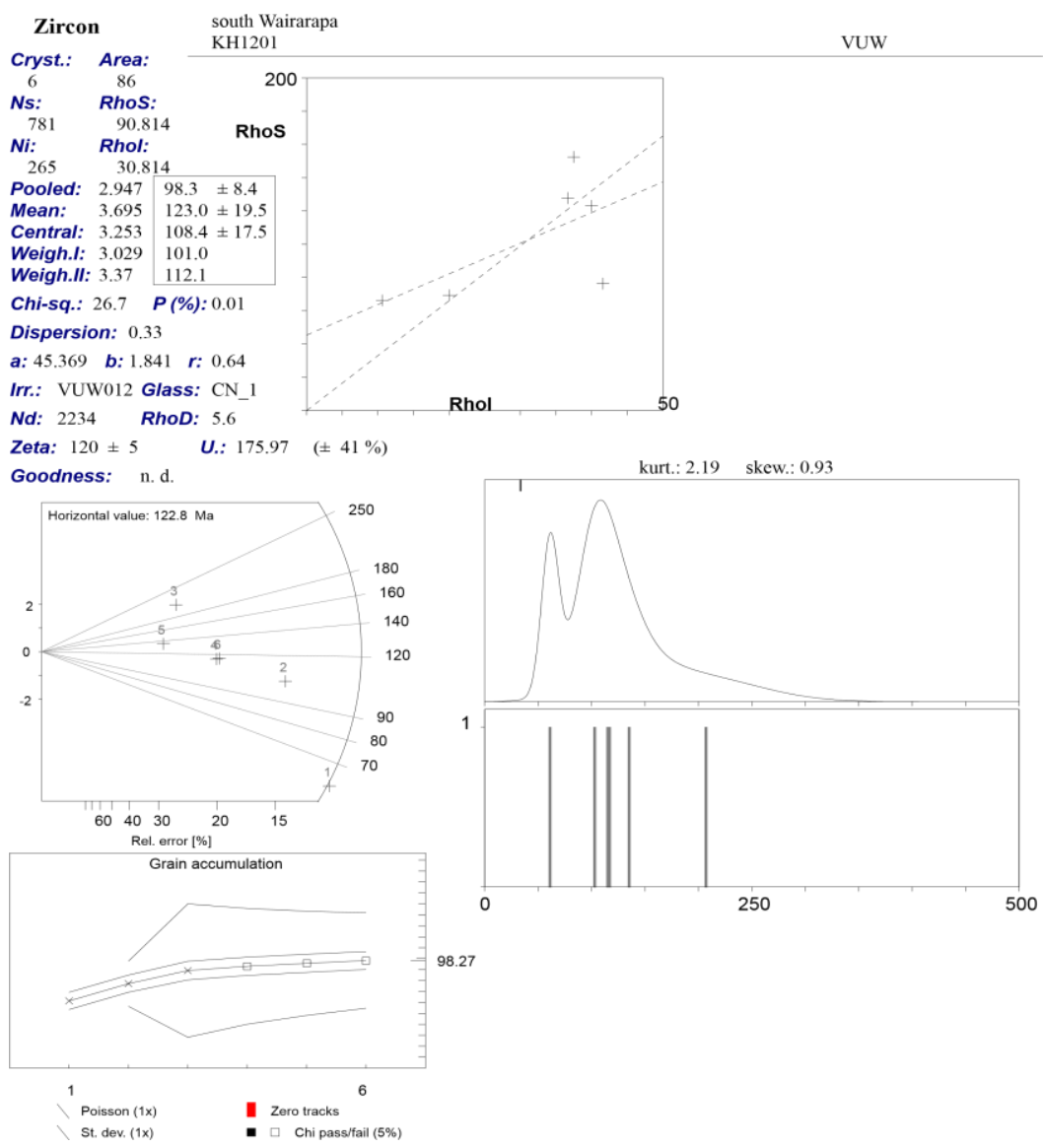

\section{$\underline{\text { KH1201 - Zircon data table }}$}

Wairarapa KH1201 Torlesse

6 Zircon crystals Sum. Ns: 781 Sum. Ni: 265

Zeta: $120+-5$ Micr. grid.: 100

Glass:CN_1 Irrad. code: VUW012 RhoD:5.6 Nd: 2234

$\begin{array}{rrrrrrrrr}\text { Cryst Ns } & \text { Ni } & \text { A } & \text { RhoS } & \text { Rhol } & \text { Age } & +-1 s & \text { Uran. } & \\ -1 & 191 & 104 & 25 & 76.400 & 41.600 & 61.41 & 8.02 & 235.639 \\ 2 & 197 & 64 & 16 & 123.125 & 40.000 & 102.60 & 15.52 & 226.576 \\ 3 & 106 & 17 & 16 & 66.250 & 10.625 & 206.17 & 54.72 & 60.184 \\ 4 & 111 & 32 & 16 & 69.375 & 20.000 & 115.51 & 23.80 & 113.288 \\ 5 & 61 & 15 & 4 & 152.500 & 37.500 & 135.21 & 39.48 & 212.415 \\ 6 & 115 & 33 & 9 & 127.778 & 36.667 & 116.04 & 23.55 & 207.694\end{array}$


$\underline{\text { KH1202 - Apatite plots }}$

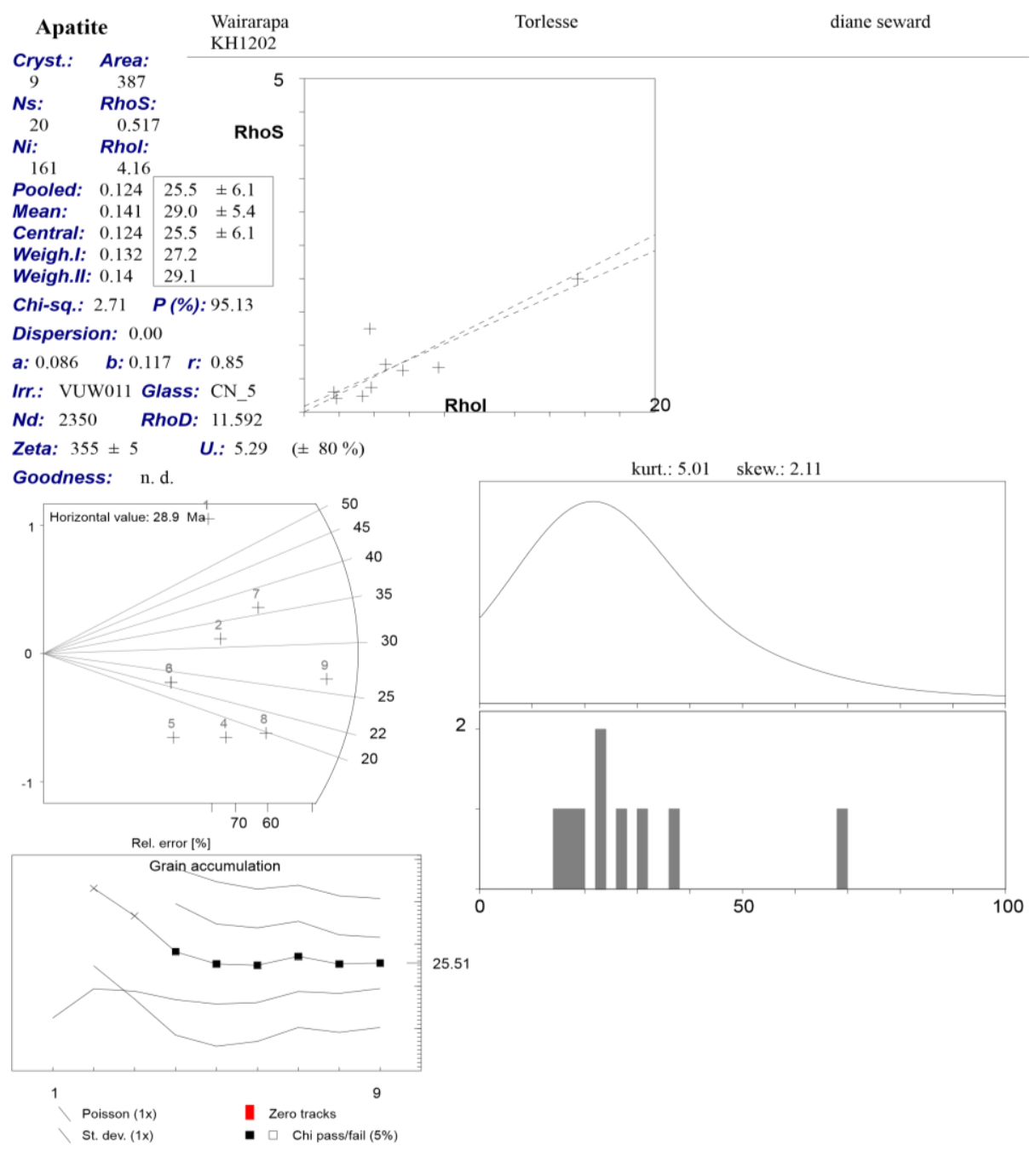

$\underline{\text { KH1202 - Apatite data table }}$

\begin{tabular}{|c|c|c|c|c|c|c|c|c|}
\hline $\begin{array}{l}\text { Waira } \\
9 \text { Apa } \\
\text { Zeta: } \\
\text { Glass }\end{array}$ & $\begin{array}{l}\text { te } \\
55 \\
\mathrm{CN}\end{array}$ & $\begin{array}{l}\text { st } \\
5\end{array}$ & $\begin{array}{l}1202 \text { T } \\
\text { ls Sum. } \\
\text { Micr. gr } \\
\text { Irrad. coc }\end{array}$ & $\begin{array}{l}\text { orlesse } \\
\text { Ns: } 20 \\
\text { id.: } 100 \\
\text { de: VUV }\end{array}$ & Sum. & hoD: 1 & .592 & Nd: 2350 \\
\hline Cryst & Ns & $\mathrm{Ni}$ & A Rhos & Rhol & Age & $+-1 s$ & Urar & \\
\hline 1 & 2 & 6 & 16 & 1.250 & 3.75 & & & 3.7 \\
\hline 2 & 2 & 13 & 28 & .714 & 4.64 & & & \\
\hline 3 & 1 & 9 & 49 & .204 & 1.837 & $22 . \varepsilon$ & 24.06 & 1.822 \\
\hline 4 & 2 & 23 & 30 & .667 & 7.667 & 17.87 & 13.18 & 7.606 \\
\hline 5 & 1 & 14 & 42 & .238 & 3.333 & 14.68 & 15.20 & 3.307 \\
\hline 6 & 1 & 9 & 16 & .625 & 5.625 & 22.82 & 24.06 & 5.581 \\
\hline 7 & 3 & 17 & 100 & .300 & 1.700 & 36. & 22.69 & 1.687 \\
\hline 8 & 3 & 31 & 81 & .370 & 3.827 & 19.88 & 12.03 & 3.797 \\
\hline & & 39 & & 2.0 & 5.600 & 26.33 & 12.52 & 215.477 \\
\hline
\end{tabular}


$\underline{\text { KH1202 - Zircon plots }}$

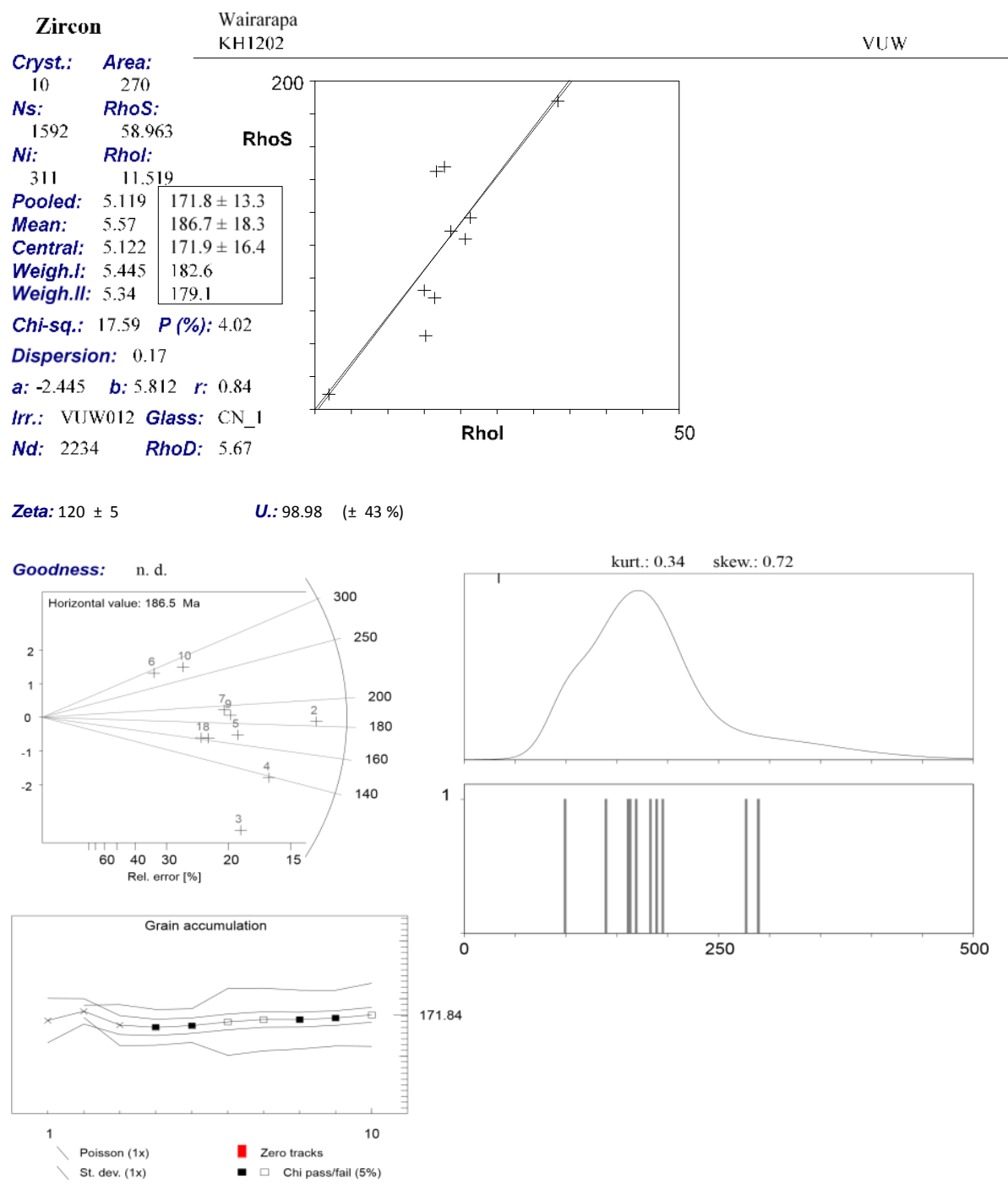

\section{$\underline{\text { KH1202 - Zircon data table }}$}

\begin{tabular}{|c|c|c|c|c|c|c|c|c|c|}
\hline \multicolumn{3}{|c|}{$\begin{array}{l}\text { Wairarapa KH12 } \\
10 \text { Zircon crystal } \\
\text { Zeta: } 120+-5 \\
\text { Glass: CN_1 }\end{array}$} & \multicolumn{3}{|c|}{$\begin{array}{l}202 \text { Torlesse } \\
\text { Is Sum. Ns: } 1592 \text { s } \\
\text { Micr. grid.: } 100 \\
\text { Irrad. code: VUW012 }\end{array}$} & \multicolumn{2}{|c|}{ Sum. Ni: 311} & \multicolumn{2}{|c|}{7 Nd: 2234} \\
\hline Cryst & Ns & $\mathrm{Ni}$ & A $\mathrm{Rh}$ & רos & Yhol & Age & $+-1 s$ & Ura & \\
\hline 1 & 106 & & 116 & 9.13 & 1.8 & & & 38.67 & \\
\hline 2 & 350 & & 30 & 116. & & & & & \\
\hline 3 & 112 & & 25 & 44 & & & & & \\
\hline 4 & 190 & 46 & 28 & 67.8 & 16. & & & 23.75 & \\
\hline 5 & 166 & 33 & 16 & 103.7 & 20. & & & 33.15 & 115 \\
\hline 6 & 87 & 10 & 6 & 145.0 & 16. & & & 97. & \\
\hline 7 & 16 & 28 & 15 & 108. & & & & & \\
\hline 8 & 11 & 24 & 16 & 72.5 & & & & & \\
\hline 9 & 16 & & 9 & & & & & & \\
\hline 10 & 133 & & 69 & 147.778 & 17.778 & & 276.76 & 74.37 & 99.45 \\
\hline
\end{tabular}


$\underline{\text { KH1305 - Apatite plots }}$

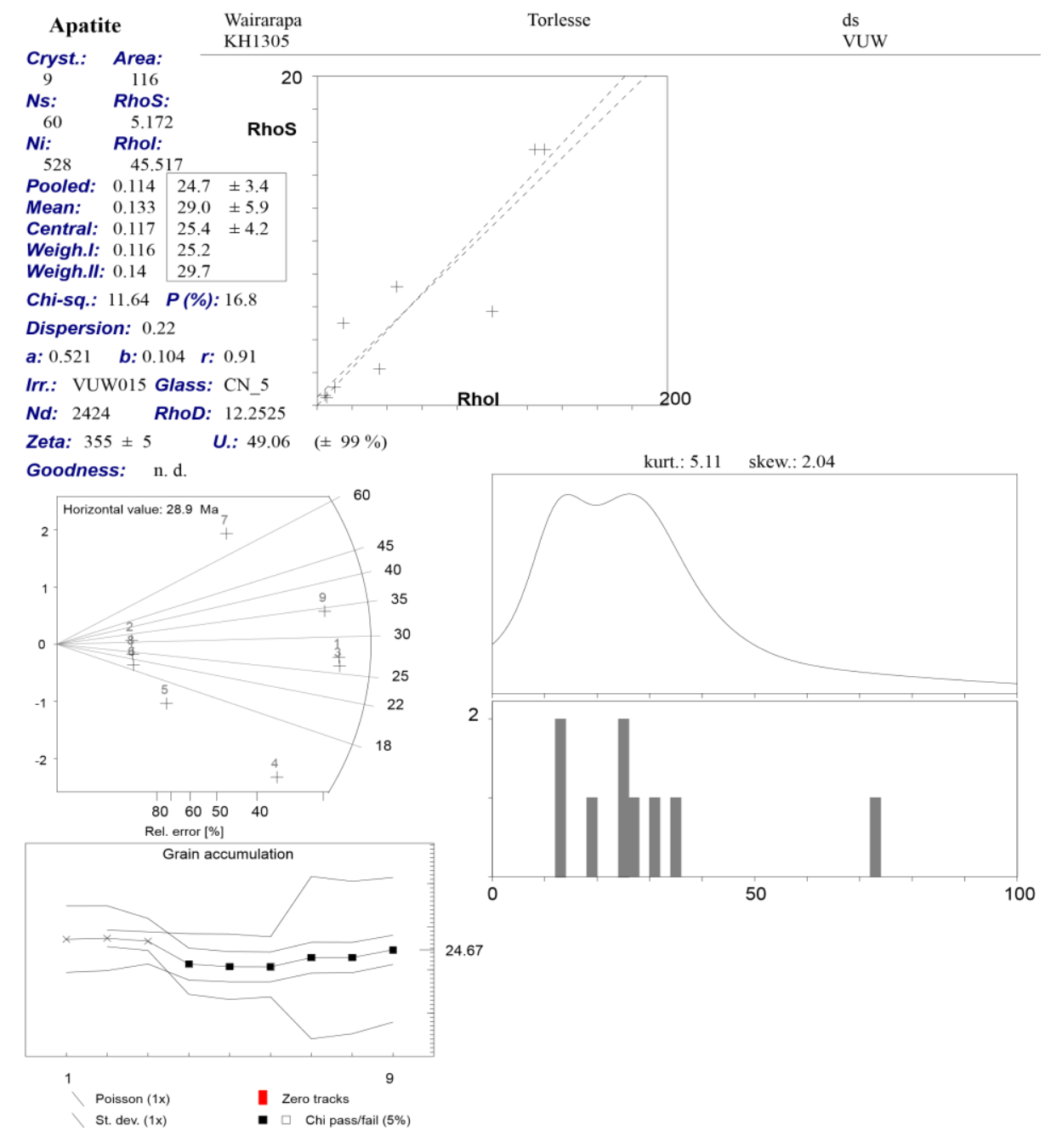

\section{KH1305 - Apatite data table}

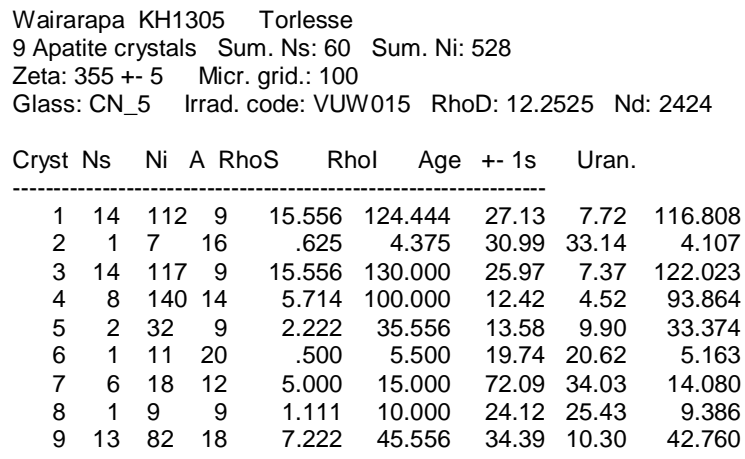

